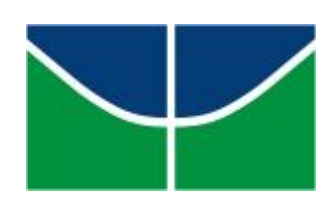

UNIVERSIDADE DE BRASÍLIA

\title{
BIOLOGIA DO GLIOBLASTOMA MULTIFORME - DA DINÂMICA DE ATIVAÇÃO MICROGLIAL AO PAPEL DO CANAL DE POTÁSSIO Kv 10.1
}

FERNANDO FRANCISCO BORGES RESENDE

TESE DE DOUTORADO

EM SAÚDE ANIMAL

BRASÍLIA/DF 2016 


\section{UNIVERSIDADE DE BRASÍLIA}

\section{BIOLOGIA DO GLIOBLASTOMA MULTIFORME - DA DINÂMICA DE ATIVAÇÃO MICROGLIAL AO PAPEL DO CANAL DE POTÁSSIO Kv 10.1}

FERNANDO FRANCISCO BORGES RESENDE

ORIENTADOR: RICARDO TITZE DE ALMEIDA

TESE DE DOUTORADO

EM SAÚDE ANIMAL

PUBLICAÇÃO: 005/2016

BRASÍLIA/DF

FEVEREIRO/2016 
UNIVERSIDADE DE BRASÍLIA

BIOLOGIA DO GLIOBLASTOMA MULTIFORME - DA

DINÂMICA DE ATIVAÇÃO MICROGLIAL AO PAPEL DO

CANAL DE POTÁSSIO Kv 10.1

FERNANDO FRANCISCO BORGES RESENDE

TESE DE DOUTORADO SUBMETIDA AO PROGRAMA DE PÓS-GRADUAÇÃo EM SAÚDE ANIMAL, COMO PARTE DOS REQUISITOS NECESSÁRIOS À OBTENÇÃO DO GRAU DE DOUTOR EM SAÚDE ANIMAL

APROVADA POR:

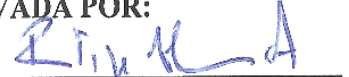

Ricardo Titze de Almeida, Professor doutor (Universidade de Brasília) (ORIENTADOR)

Márcio Botelho de Castro, Professor doutor (Universidade de Brasília) (EXAMINADOR IXTERNO)

Hhbocen

Márcía Renata Mortari, Professora doutora (Universidade de Brasília) (EXAMINADORA EXTERNA)

Móncic Ruato Morioi

Anamélia Lorenzetti Bocca, Professora doutora (Universidade de Brasília)

(EXAMINADORA EXTERNA)

Marise Botalamza.

Mariza Bortolanza, Doutora (Universidade de São Paulo)

(EXAMINADORA EXTERNA)

BRASÍLIA/DF, 29 de FEVEREIRO de 2016 


\section{REFERÊNCIA BIBLIOGRÁFICA E CATALOGAÇÃO}

RESENDE, F.F.B. Biologia do glioblastoma multiforme - da dinâmica de ativação microglial ao papel do canal de potássio Kv 10.1, Brasília: Faculdade de Agronomia e Medicina Veterinária, Universidade de Brasília, 2016, 135 p. Tese de Doutorado.

Documento formal, autorizando reprodução desta tese de doutorado para empréstimo ou comercialização, exclusivamente para fins acadêmicos, foi passado pelo autor à Universidade de Brasília e acha-se arquivado na Secretaria do Programa. O autor reserva para si os outros direitos autorais, de publicação. Nenhuma parte desta tese de doutorado pode ser reproduzida sem a autorização por escrito do autor. Citações são estimuladas, desde que citada a fonte.

\section{FICHA CATALOGRÁFICA}

Resende, Fernando Francisco Borges.

Biologia do glioblastoma multiforme - da dinâmica de ativação microglial ao papel do canal de potássio Kv 10.1 / Fernando Francisco Borges Resende; orientação de Ricardo Titze de Almeida - Brasília, 2016. 135 p. : il.

Tese de Doutorado (D) - Universidade de Brasília/Faculdade de Agronomia e Medicina Veterinária, 2016.

1. RNAi 2. Glioma 3. Kv 10.1 4. Micróglia e 5. Eag1. I. FERNANDO, F. F. B. II. Título. 


\section{AGRADECIMENTOS}

Desafio maior que desenvolver este trabalho, foi escrever apenas em duas páginas os agradecimentos a todos que fizeram parte da minha vida, tanto pessoal quanto profissional.

Em primeiro, agradeço a Deus por ter me dado força, saúde e sabedoria para concluir esta etapa.

Logo em seguida, agradeço aos meus pais, que sempre incentivaram minha educação. Obrigado Sr. Fernando e Sra. Neiva por sempre estarem presentes.

Continuando em família, obrigado às minhas queridas irmãs: Kleyne, Kátia e Kelly, bem como os cunhados, sobrinhas e sobrinhos, pelo apoio e incentivo.

Preciso agradecer ao Professor e amigo Ricardo Titze de Almeida pela confiança, mesmo sabendo das minhas limitações em biologia molecular no início, pela paciência e pelo apoio. Obrigado pelas demonstrações de sabedoria e humildade em todos os momentos.

Agradeço muito a todos os colegas/amigos que fizeram ou fazem parte do laboratório Tecnologias para Terapia Gênica - UnB. Obrigado Ana Paula, Ludymilla, Bruno, Thais, Simoneide, Cátia, Wesley, Natália, Camila e Franciele.

Obrigado a equipe do laboratório Molecular Physiology, Center for Integrative Physiology and Molecular Medicine (CIPMM), University of Saarland, Homburg, Alemanha, em especial ao Prof. Frank Kirchhoff por ter me recebido de forma tão nobre em seu laboratório e sua casa; Anja Scheller pela paciência e disposição em ensinar; Frank Rhode por compartilhar seu grande conhecimento e pela amizade; Daniel Rhode pelo trabalho dedicado aos animais utilizados neste trabalho; Ute Legler pelo incrível apoio logístico e por ter doado seu tempo para me ajudar nos primeiros dias em Homburg; Luciana, Pasquale, Isabella, Fei, Cai, Mikhail, Laura, Hannah, Laura e Alexander pela cordialidade, amizade, troca de conhecimentos e, principalmente, pelos bons momentos.

Estendo meus agradecimentos à Professora Elaine Del Bel, do laboratório de Neurofisiologia e Biologia Molecular - FORP USP, por me oferecer a oportunidade de ir à Alemanha desenvolver parte deste estudo.

O presente trabalho foi realizado com apoio da Coordenação de Aperfeiçoamento de Pessoal de Nível Superior - CAPES/Brasil. Agradeço grandemente a esta instituição pelo apoio financeiro. 
Meu agradecimento final e mais profundo é para Maíra Gonçalves, que sempre presente, me incentivou e entendeu os momentos de ausência dos últimos anos. Dificuldades decorrentes do esforço para atingir os resultados e chegar ao final desta longa caminhada com uma tese digna e honesta, a altura de toda a confiança depositada pelas pessoas citadas acima. Sou grato por cada sorriso, beijo, abraço e gesto carinhoso. Obrigado meu bem, te amo!

"Agradeço todas as dificuldades que enfrentei; não fosse por elas, eu não teria saído do lugar. As facilidades nos impedem de caminhar. Mesmo as críticas nos auxiliam muito”. Chico Xavier 


\section{RESUMO}

O glioblastoma multiforme é o tumor cerebral mais agressivo. Já a micróglia representa $30 \%$ da massa tumoral e desempenha um importante papel na tumorigênese. Este trabalho buscou estudar o padrão de infiltração e alteração morfológica da micróglia no tecido tumoral formado por células da linhagem GL261mCherry implantadas ortotopicamente. Além disto, buscou-se examinar o papel do canal de potássio Kv 10.1, correlacionado ao crescimento tumoral, primeiro na interação da micróglia com as células tumorais e, segundo, frente à lesão celular causada pelo fármaco de escolha ao tratamento do glioma, a temozolomida. Camundongos CX3CR1-EGFP receberam injeções intracorticais de células de glioblastoma multiforme capazes de expressar a proteína fluorescente mCherry. Microscopia de epifluorescência e confocal foram empregadas nas análises morfométricas, ao passo que a microscopia do tipo 2-photon (2P-LSM) foi usada para visualizar as células tumorais e microgliais no cérebro de animais vivos. Os resultados deste estudo revelaram uma microgliose intensa em áreas cerebrais logo após a implantação do tumor, isto é, aos 30 minutos. Nos primeiros três dias, a micróglia tende a formar aglomerados de células em torno dos tumores. Para, em seguida, infiltrar no centro tumoral, onde permanece durante todos os pontos de tempo estudados, de 6 a 18 dias. Com o aumento da massa tumoral, as células tumorais perdem progressivamente a sua forma original, assumindo uma morfologia heterogênea e difusa; o tamanho do corpo celular (perímetro) passou de $10 \mu \mathrm{m}$, três dias após o implante, para $52 \mu \mathrm{m}$ aos 18 dias. Em contato com o glioma, a micróglia também muda sua morfologia. A forma tornou-se amebóide, com corpos celulares alargados. O corpo celular (área) cresceu de 366 \pm 0.0 $\mu \mathrm{m}^{2}$, na micróglia em vigilância, para $1310 \pm 146.0 \mu \mathrm{m}^{2}$ e ramificações curtas, ou mesmo ausência de ramificações no fenótipo ativado. Aos 12 dias após o implante, foi notada a presença de células multinucleadas de glioma, os policariócitos, em contato íntimo com a micróglia ativada. Sobre o canal Kv-10.1, este foi expresso em células cultivadas de glioma, de micróglia (linhagem BV-2) e também em tecido tumoral de camundongos implantados com o tumor. A supressão deste canal, em células de glioma, potencializou a injúria por TMZ em 29\%, conforme ensaio de MTT. Em conclusão, a micróglia apresentou um padrão espaço-temporal de infiltração no glioma, o que favorece influências recíprocas e pró-tumorigênicas. Já o canal Kv-10.1, pode tanto representar uma via de comunicação entre estes tipos celulares, quanto ser um potencial alvo para a 
terapêutica do glioma, já que foi capaz de potencializar os efeitos da temozolomida na morte celular de linhagens de glioma.

Palavras-chave: Kv 10.1, Eag1, RNAi, glioma, terapia gênica, TMZ, modelo animal. 


\section{ABSTRACT}

Glioblastoma multiforme is the most aggressive brain tumor. Microglia represents $30 \%$ of the tumor mass, and plays a role in tumorigenesis. This work studied the pattern of microglial growth into brain tumor tissue formed by orthotopically implanted glioma cells of the established GL261 cell line. In addition, we examined the expression of the $\mathrm{Kv} 10.1$ potassium channel that frequently correlates with tumor growth. CX3CR1-EGFP mice received intracortical injections of GL261 tumor cells with stable expression of the red fluorescent protein mCherry. Epifluorescence - and confocal laser-scanning microscopy were employed in the analysis of tissue sections, whereas two-photon laserscanning microscopy (2P-LSM) was used to visualize tumor cells and microglia in the brain of living animals. Our results revealed an intense microgliosis in brain areas already shortly after tumor implantation, i.e. at 30 minutes. In the first three days, microglia formed clusters of cells around tumors mass. Then cells infiltrated the tumor area, where they remained during all the time points studied, from 6 to 18 days. As tumor increased in size, GL261 cells progressively lost their original shape, assuming a heterogeneous and diffuse morphology. Soma size increased from 10 to $52 \mu \mathrm{m}$. In contact with the glioma, microglia also changed its morphology. Cell bodies enlarged from $366 \pm 0.0 \mu \mathrm{m}^{2}$, in quiescent microglia, to $1310 \pm 146.0 \mu \mathrm{m}^{2}$. The shape became amoeboid, with enlarged cell bodies and short processes (or even absence of them). Remarkably, we found microglial processes that closely surrounded glioma cells. Microglia also grew around multinucleated polycariocytes, found in tumors at 12 days. The $\mathrm{Kv} 10.1$ channel was expressed in cultured GL261 cells, microglia cell line (BV-2) and also in mouse tumors. Suppression of Kv10.1 caused a 29\% decrease in the viability of glioma cells injured by TMZ. In conclusion, microglia presented a temporal and spatial pattern of infiltration in glioma tumors, which favors reciprocal and protumorigenic influences. $\mathrm{Kv} 10.1$ expressed by glioma cells in close contact with microglia may represent a communication pathway between microglia and cancer cells and, could be a potential target for antiglioma gene therapy, since it potentiated the effects of temozolomide in glioma cell lines.

Key-words: Kv 10.1, Eag1, RNAi, glioma, gene therapy, TMZ, animal model. 


\section{SUMÁRIO}

AGRADECIMENTOS

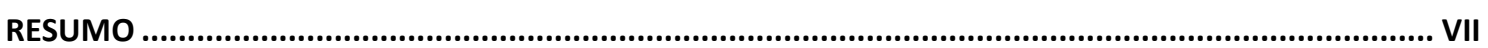

ABSTRACT

SUMÁRIO

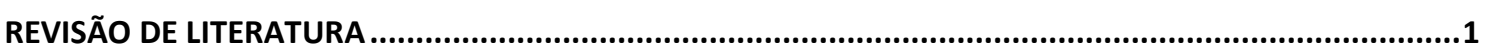

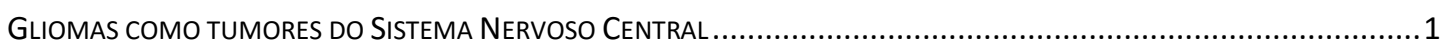

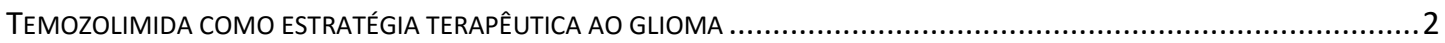

ASPECTOS GERAIS DA MICRÓGLIA, COMO CÉLULA CONSTITUINTE DO SISTEMA NERVOSO CENTRAL (SNC) ......................3

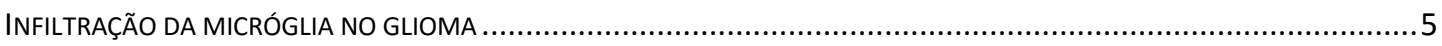

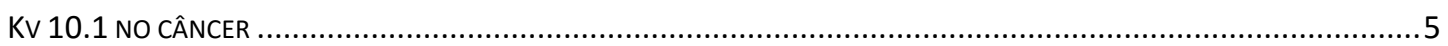

EFEITOS DA SUPRESSÃO DO CANAL DE POTÁSSIO KV 10.1 NO CÂNCER …....................................................

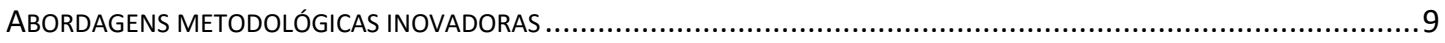

Camundongo transgênico TgH(CX3CR1-EGFP) e células de glioma GL261mCherry ........................9

Microscopia de varredura tipo 2-photon - Laser Scanning Microscopy (2P-LSM) ......................... 10

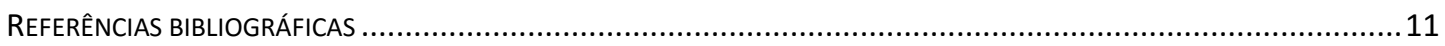

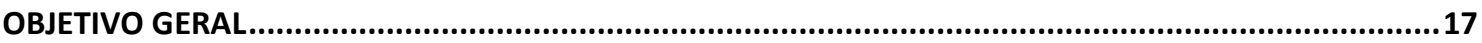

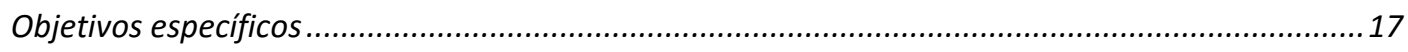

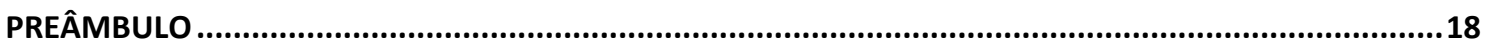

CAPÍtUlO 1 - DESENVOLVIMENTO E VALIDAÇÃO DE UM MODELO ANIMAL PARA O ESTUDO DA

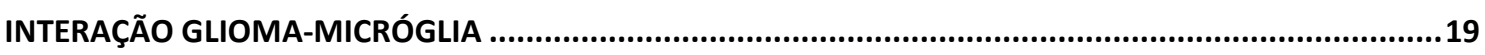

TíTULO DO ARTIGO: EVALUATION OF TGH(CX3CR1-EGFP) MICE IMPLANTED WITH MCHERRY-GL261 CELLS AS AN IN VIVO MODEL FOR MORPHOMETRICAL ANALYSIS OF GLIOMA-MICROGLIA INTERACTION

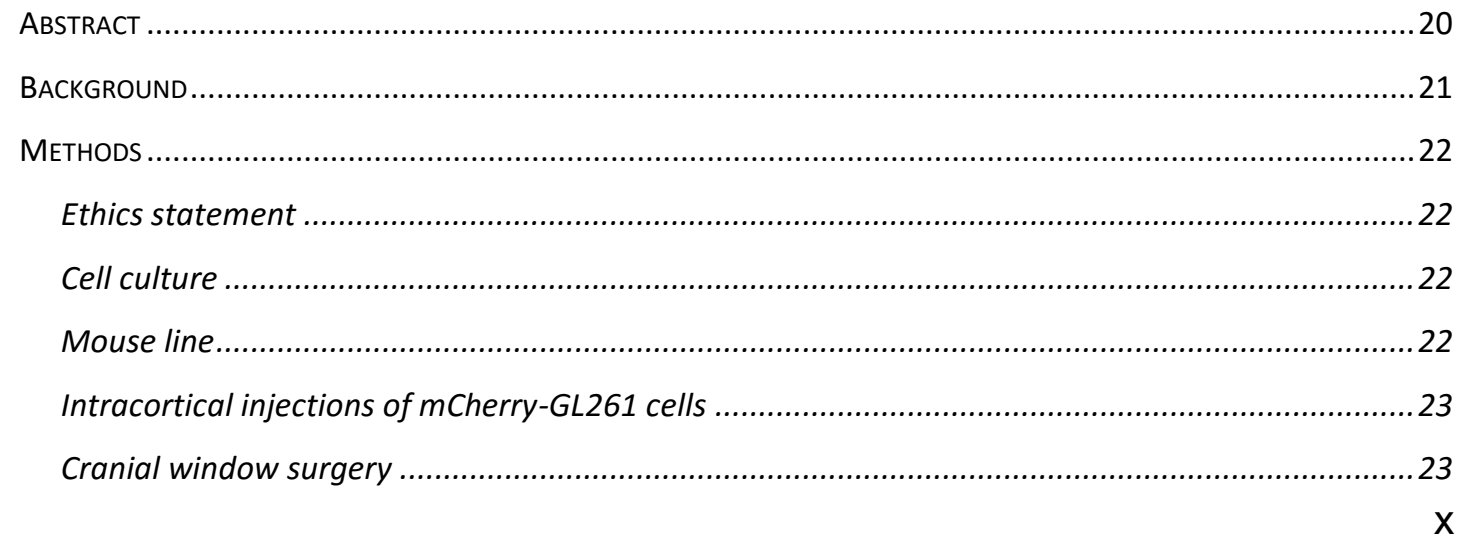


Microscopic analysis

Morphometric analysis of microglia based on skeletonization, measurement of cell length, soma

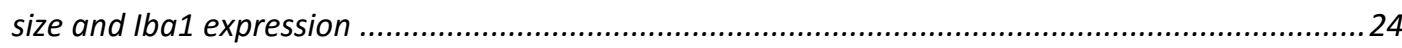

Two-photon laser-scanning microscopy and image acquisition ................................................2

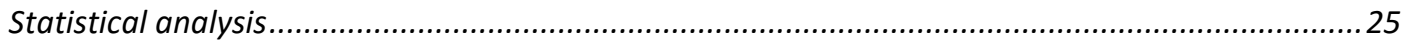

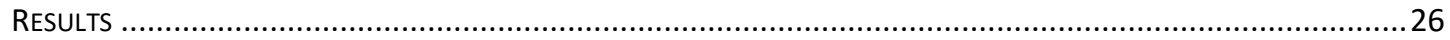

Analysis of microglial cells infiltration during glioma growth.................................................26

Tracking microglial morphological changes and quantitative cell analysis during their infiltration into the tumor mass.

Longitudinal measure of microglial activation and morphometrical analysis of microglia during the

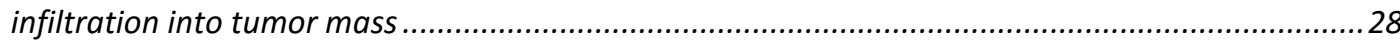

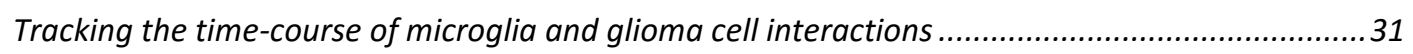

In vivo imaging by 2P-LSM reveals the kinetics of microglial interaction with glioma cells ..............33

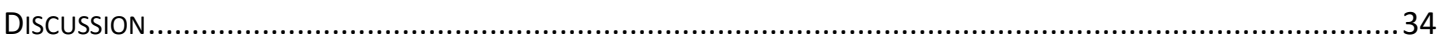

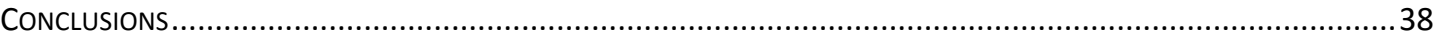

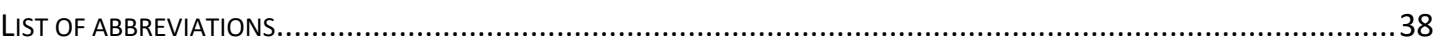

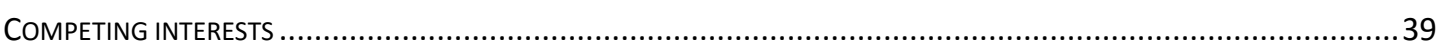

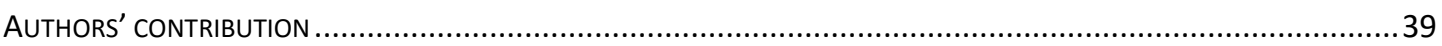

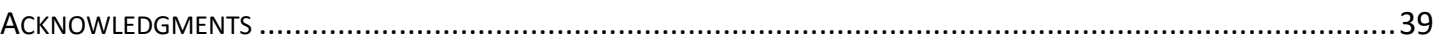

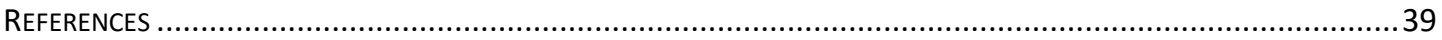

CAPÍTULO 2 - SOBRE O PAPEL DO CANAL DE POTÁSSIO KV 10.1 NA INTERAÇÃO MICRÓGLIA - GLIOMA

TÍTULO DO ARTIGO: POTASSIUM CHANNEL KV 10.1 EXPRESSION IN MICROGLIA-GLIOMA INTERACTION

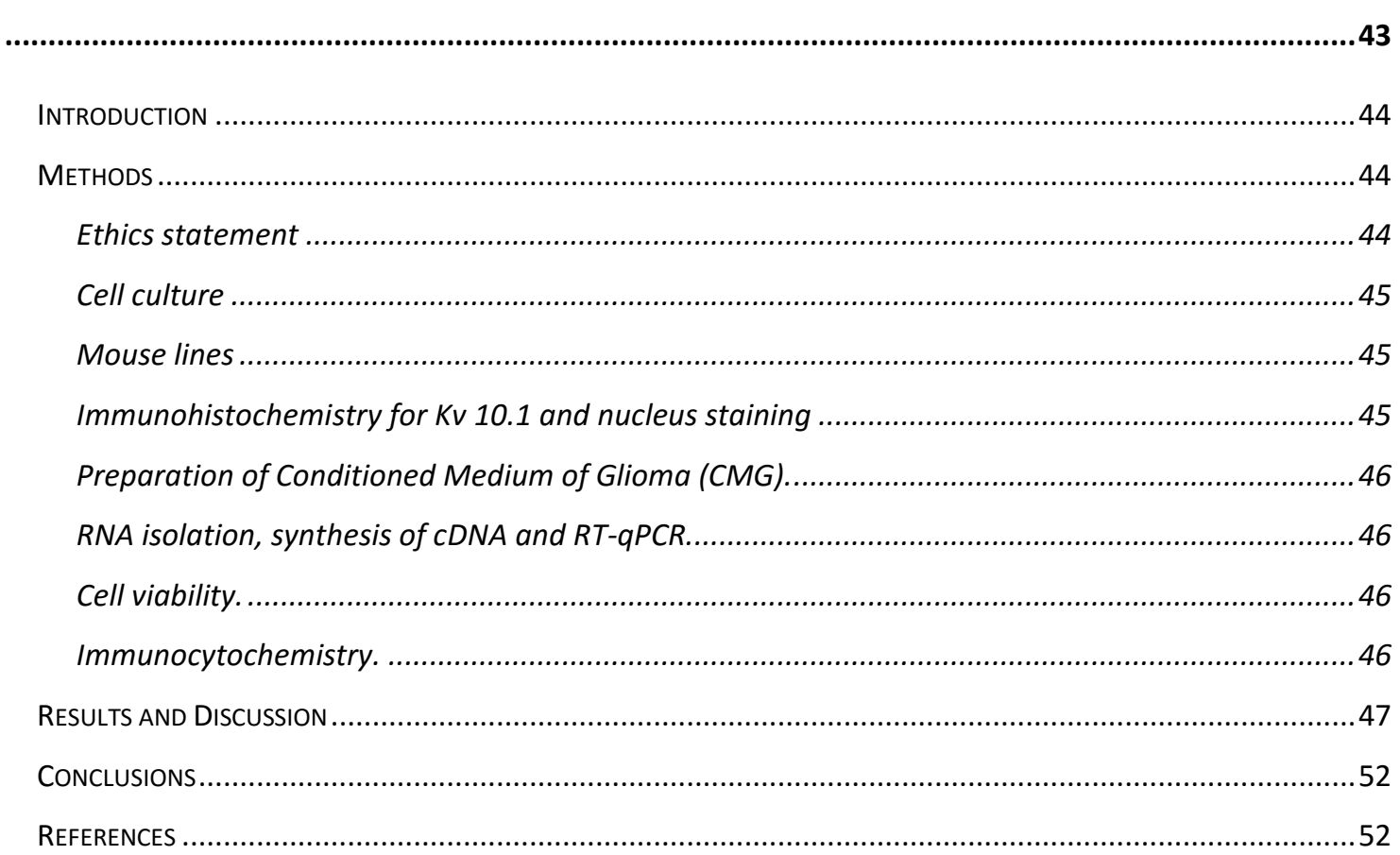




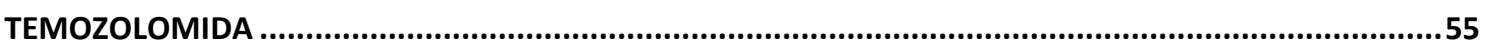

TÍTULO DO ARTIGO: SUPPRESSION OF THE EAG1 $\mathrm{K}^{+}$CHANNEL SENSITIZES GLIOBLASTOMA CELLS TO THE

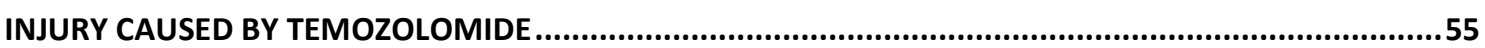

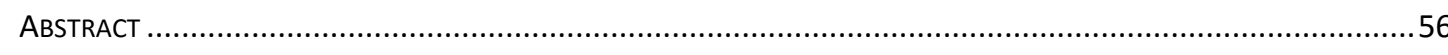

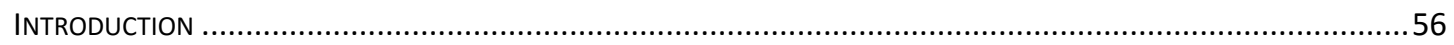

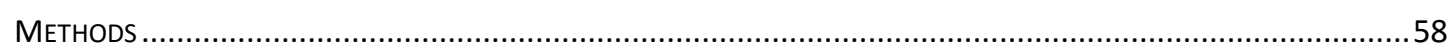

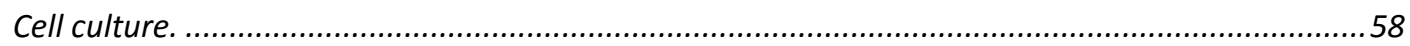

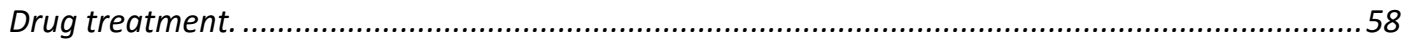

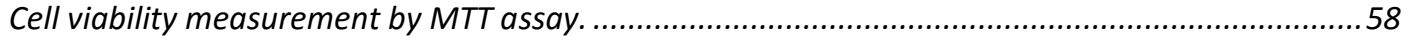

Cell transfection method ....................................................................................................... 58

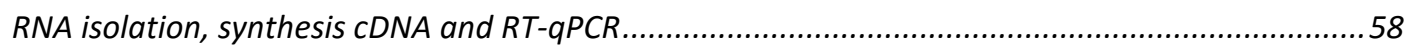

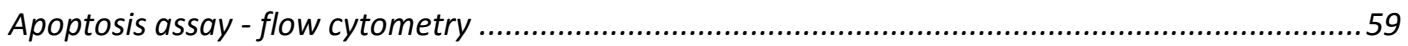

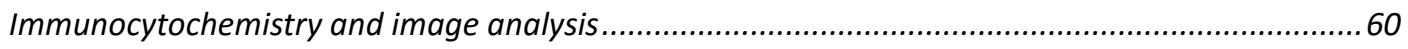

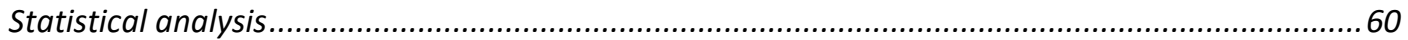

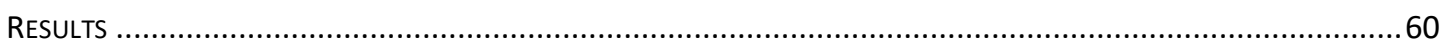

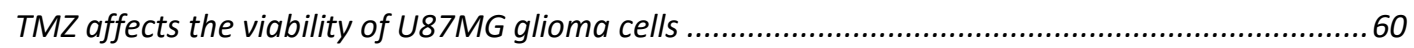

Effects of TMZ and pKv10.1-3 on glioma cell viability and Eag1 expression.................................61

Astemizole and pKv10.1-3 reduce the viability of glioma cells ................................................62

Suppression of Eag1 by astemizole or pKv10.1-3 sensitize cells to TMZ injury. ...........................63

Apoptosis of GBM cells determined by flow cytometry .............................................................6 65

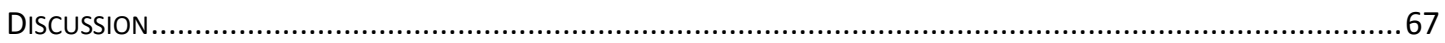

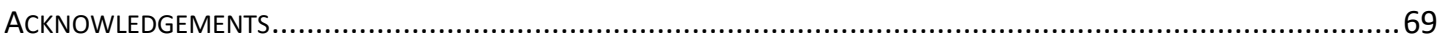

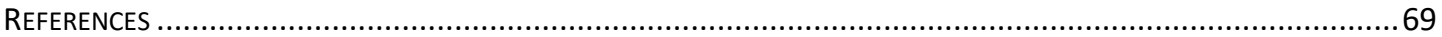

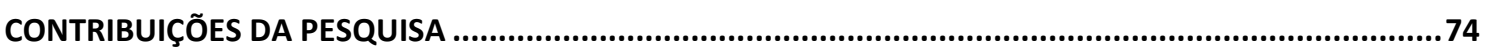

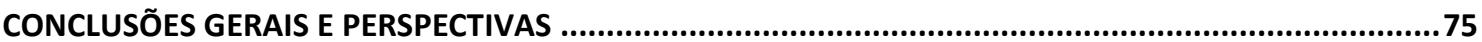

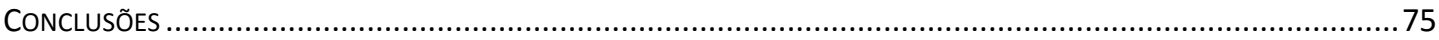

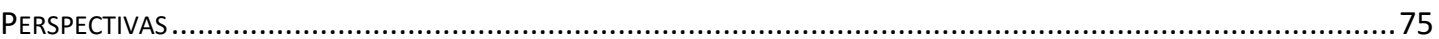

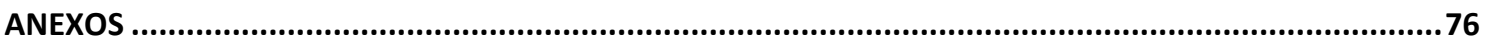

ANEXO 1 - THE ROLE OF NEURONAL NITRIC OXIDE SYNTHASE ENZYME (NNOS) IN THE CELL DAMAGE OF GLIOBLASTOMA

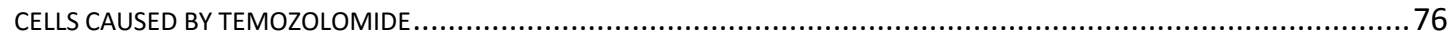

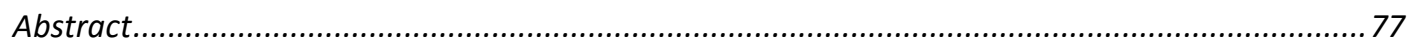

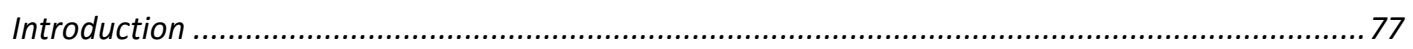

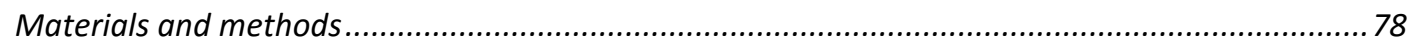

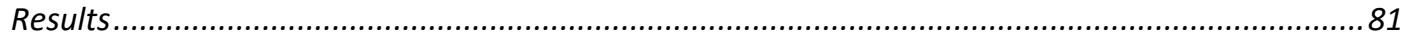




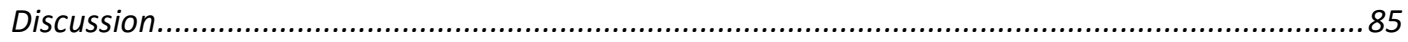

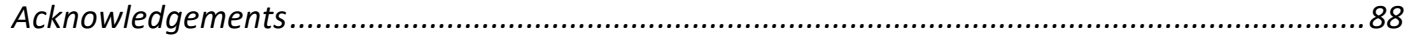

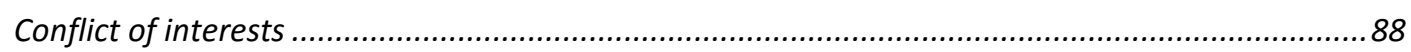

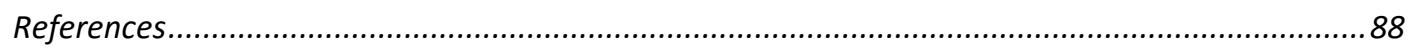

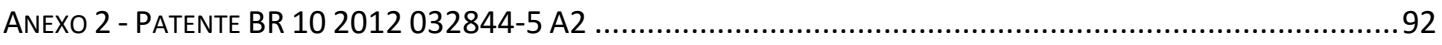

ANEXO 3 - POTENTIAL ROLE OF NEURONAL NITRIC OXIDE SYNTHASE ISOFORM IN THE ONSET OF INTERVERTEBRAL DISC

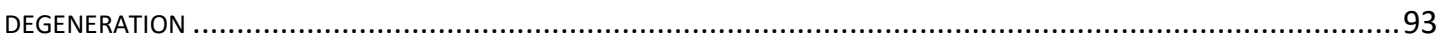

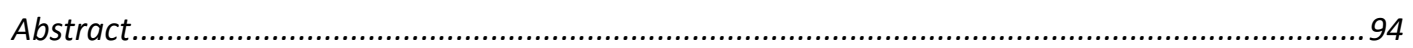

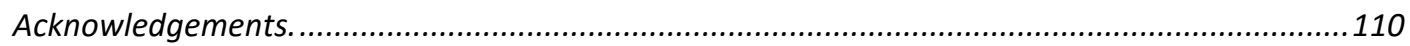

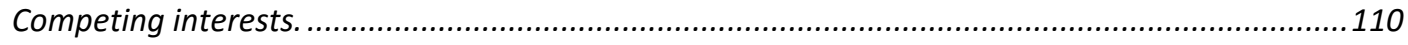

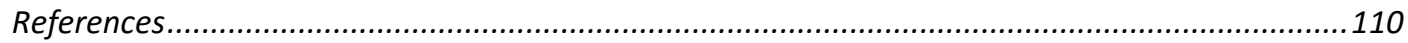

ANEXO 4 - E-BOOK: BIOLOGIA MOLECULAR - FUNDAMENTOS E TÉCNICAS BÁSICAS ...........................................114

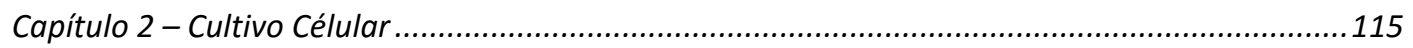

Capítulo 12 - Quantificando sequências de RNAm de interesse ..............................................115 


\section{Revisão de literatura}

\section{Gliomas como tumores do Sistema Nervoso Central}

Gliomas são tumores intracerebrais derivados das células da glia. Portanto, são classificados histologicamente de acordo com a semelhança das células neoplásicas em relação às células gliais normais e os relativos graus de malignidade. Neste sentido, o astrocitoma é composto de células tumorais que se assemelham aos astrócitos, enquanto o oligodendroglioma contêm células compatíveis com oligodendrócitos.

Do ponto de vista epidemiológico, o glioma é o tumor primário intracerebral de maior incidência e agressividade em humanos. Corresponde a $20 \%$ dos todos tumores cerebrais primários e $80 \%$ dos tumores primários malignos localizados no cérebro de humanos adultos (OSTROM et al., 2013). A incidência atinge, aproximadamente, seis em cada 100 mil pessoas ao ano. Segundo a Organização Mundial da Saúde (OMS), os astrocitomas podem ser classificados em uma escala de quatro níveis de malignidade, dividida de acordo com o padrão histológico e as alterações genéticas apresentadas (OSTROM et al., 2013). Dentre estes, o glioblastoma multiforme (GBM) está classificado na mais alta escala, ou seja, nível IV. Este representa $54,7 \%$ do total de tumores originados por células da glia (Figura 1).

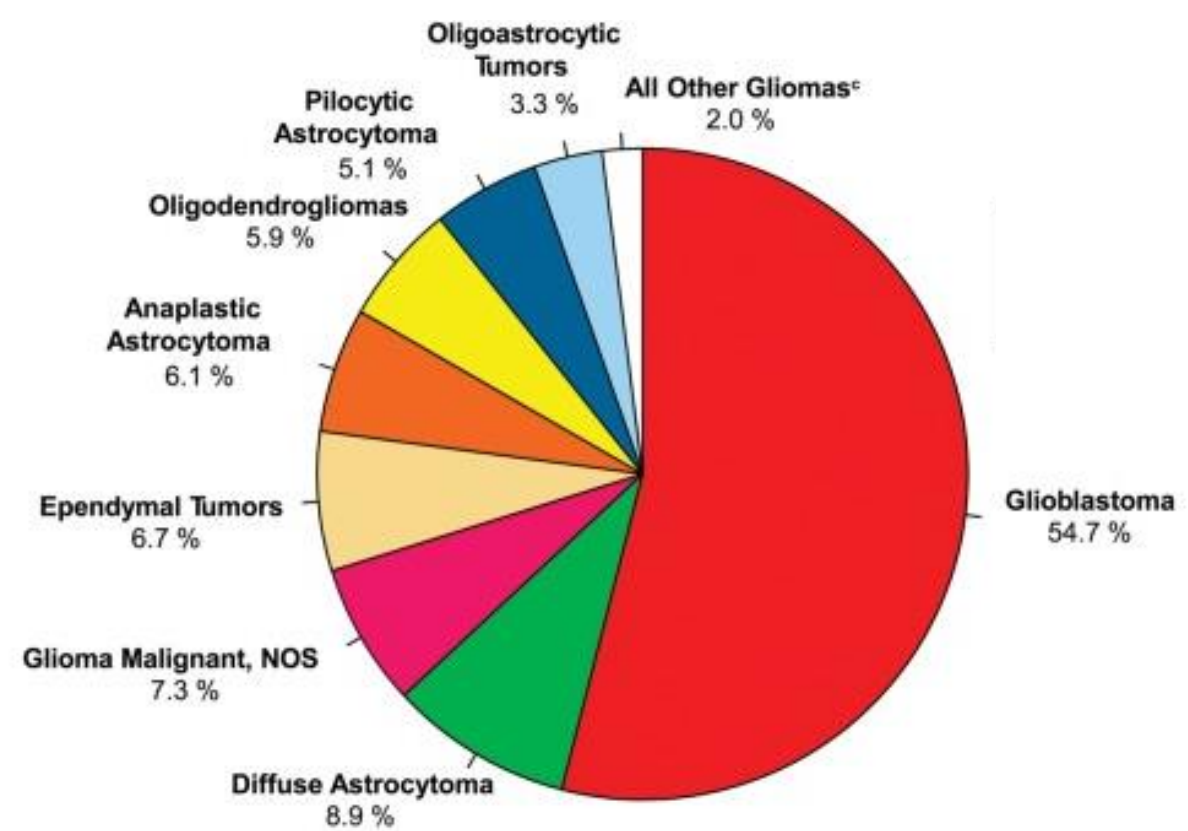

Figura 1. Distribuição por histologia e tipos de gliomas na população americana nos períodos de 2007-2011. (OSTROM et al., 2013). 
A incidência fica em torno de 3,19 casos para 100.000 pessoas. Os pacientes afetados apresentam sobrevida média de apenas 15 meses (MCLENDON; HALPERIN, 2003; STUPP et al., 2009). Devido à sua localização, o GBM representa um risco aumentado para a excisão cirúrgica. A recorrência do tumor, com subsequente invasão de outras áreas, é comum em pacientes após a ablação cirúrgica do GBM (WATKINS; SONTHEIMER, 2012). Finalmente, o GBM frequentemente desenvolve resistência aos tratamentos de quimioterapia e radioterapia atuais (NAGASAWA et al., 2012; RICARD et al., 2012).

\section{Temozolimida como estratégia terapêutica ao glioma}

O tratamento de escolha para o glioblastoma inclui remoção cirúrgica, seguida de radioterapia e quimioterapia com temozolomida (TMZ). Isto aumenta em aproximadamente 2,5 meses a sobrevida dos portadores humanos (STUPP et al., 2009).

A apresentação comercial da temozolomida denomina-se Temodal ${ }^{\circledR}$ (ScheringPlough, EUA). O fármaco é classificado como um agente alquilante de segunda geração, da classe dos Triazenos, derivado da imidazotetrazina, que sofre uma rápida conversão química, a um pH fisiológico, no ativo monometil triazenoimidazol carboxamida (MTIC). A ação citotóxica do MTIC é devida à metilação do DNA nas posições $\mathrm{O}^{6} \mathrm{e}^{7}$ da guanina e $\mathrm{N}^{3}$ da adenina (DENNY et al., 1994). Desta forma, tem a capacidade de reduzir a proliferação das células tumorais por dificultar as ações de reparo do ciclo celular, resultado em correção aberrante da adução metilo (NAGASAWA et al., 2012). A temozolomida é uma substância lipofílica de baixa massa molecular (194.15 g/mol), capaz de ser absorvida pelo sistema gastrointestinal. Além disso, atravessa a barreira hematoencefálica (BHE), alcançando os tumores intracerebrais (NAGASAWA et al., 2012; NEWLANDS et al., 1992).

Embora a associação de TMZ com radioterapia aumente a expectativa de vida do paciente, os efeitos do fármaco são limitados. O processo de metilação do DNA, por exemplo, pode ser contornado devido aos mecanismos de adaptação que as células tumorais desenvolvem, causando resistência ao tratamento (TENTORI; GRAZIANI, 2009). 


\section{Aspectos gerais da micróglia, como célula constituinte do sistema nervoso central (SNC)}

O SNC é composto por outros tipos celulares além dos neurônios. Cerca de 50\% da população são células da glia (Figura 2), que tem a função de sustentar, proteger, isolar e nutrir os neurônios (JESSEN, 2004).

Entre as principais células da glia está a micróglia - objeto do atual estudo, além dos astrócitos, e oligodendrócitos. Há evidências de que estas células, juntamente com a linha celular endotelial, fornecem suporte a todo o microambiente cerebral, como controlar a liberação de neurotransmissores, regulação iônica, eliminação de metabólitos, liberação de neuropeptídios e neurotrofinas, além de regular a neurogênese (JESSEN, 2004).

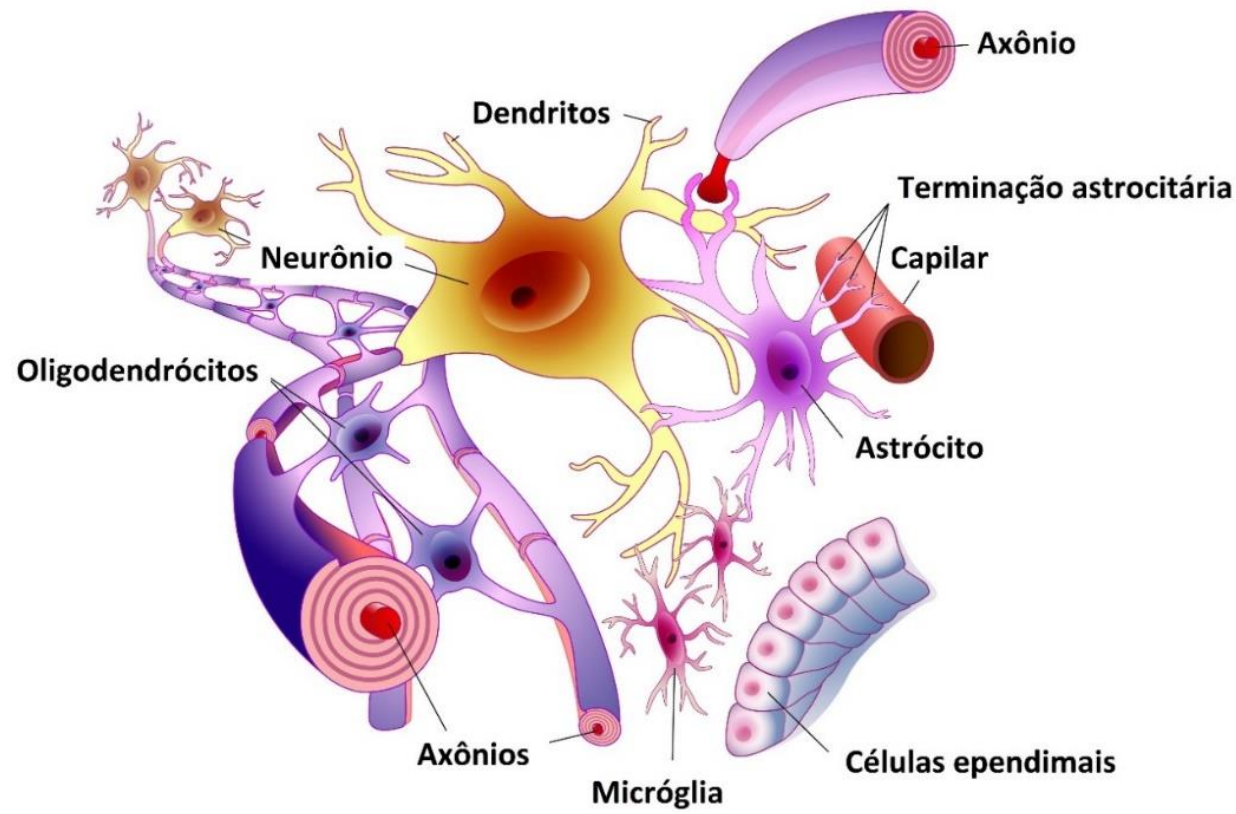

Figura 2. Representação das células residentes no sistema nervoso central. O SNC de mamíferos é composto de neurônios, células da glia (micróglia, astrócitos e oligodendrócitos), além de outros tipos celulares de suporte. Imagem gentilmente cedida pelo Prof. Dr. Frank Kirchhoff (Departamento de Fisiologia Molecular, UKS, Homburg, Alemanha).

Evidências científicas mostram que o SNC não está isolado do sistema imunológico pela barreira hematoencefálica ou a falta de drenagem, mas possui um mecanismo único de proteção, apto a responder ativamente a processos inflamatórios ou qualquer tipo de injúria (BECHMANN; NITSCH, 2001; MARTINO; PLUCHINO, 2007). A micróglia é a célula responsável por executar a função dos macrófagos no SNC, 
fagocitando debris celulares decorrentes de apoptose, além de responder aos estímulos imunológicos, provenientes de dentro ou fora do SNC (CARSON, 2002; ROCK et al., 2004). A micróglia apresenta características de células mielóides no SNC (PETERS; JOSEPHSON; VINCENT, 1991). Em seres humanos e outros vertebrados, representam entre 5 a 20\% de todas as células da glia (PELVIG et al., 2008). Exercem papel fundamental na regulação fisiológica e patológica do cérebro (KETTENMANN et al., 2011; KREUTZBERG, 1996; RANSOHOFF; PERRY, 2009). No cérebro saudável, a micróglia é marcada pela heterogeneidade e exibe um fenótipo quiescente, caracterizado morfologicamente pela grande quantidade de ramificações. A micróglia não reativa é dinâmica, permanece em constante vigilância e é capaz de modificar sua morfologia, resultando em motilidade celular (DAVALOS et al., 2005; NIMMERJAHN; KIRCHHOFF; HELMCHEN, 2005).

Trabalhos anteriores também sugerem que a micróglia participa no desenvolvimento normal do cérebro por meio da secreção de fatores neurotróficos, tais como o fator de crescimento semelhante à insulina 1 (IGF-1), fator neurotrófico derivado do cérebro (BDNF), fator de crescimento transformante- $\beta$ (TGF- $\beta$ ) e fator de crescimento do nervo (NGF) (TREMBLAY et al., 2011). Além disso, funções fagocíticas de micróglia apoiam a neurogênese e a sinaptogênese (MADINIER et al., 2009). A micróglia responde rapidamente a patógenos e estímulos traumáticos, mudando seu fenótipo para ativado, com formato amebóide. Os estágios de ativação da micróglia também foram definidos com base em dados morfológicos, moleculares e funcionais. Assim, a micróglia totalmente ativada apresenta-se como macrófagos periféricos. Uma vez ativada, a micróglia pode produzir diversos mediadores pró-inflamatórios que contribuem para o combate a patógenos, por exemplo. No entanto, embora uma resposta imune eficiente seja necessária para a defesa do SNC, a ativação excessiva pode causar danos no tecido e levar à neurodegeneração. Como uma primeira linha de defesa no SNC, a função crucial da micróglia é gerar resposta imune inata e adaptativa. A imunidade inata é a resposta antígeno inespecífica inicial que resulta em fagocitose microglial e rápida produção de citocinas inflamatórias (FU, et al., 2014). Ao apresentar antígenos, a imunidade adaptativa pode ser induzida pela micróglia (SCHWARTZ et al., 2006). 


\section{Infiltração da micróglia no glioma}

Esta etapa da revisão de literatura irá abordar aspectos da multiplicação celular e migração da micróglia em direção ao interior da massa tumoral do glioma, tipo tumoral a ser investigado no presente estudo (Capítulo 1).

Ao que se refere à biologia do tumor, a gliomagenesis é marcada por mudanças no fenótipo e migração das células microgliais (WEI; GABRUSIEWICZ; HEIMBERGER, 2013). Durante o crescimento tumoral, as células microgliais atuam primeiramente como os macrófagos do sistema nervoso central, migrando para os sítios tumorais para apresentar antígenos e liberar citocinas (ALOISI, 2001). No entanto, esta atividade antitumoral esperada é descrita apenas em estudos in vitro (SUTTER; HEKMAT; LUCKENBACH, 1991). Publicações anteriores sugerem que a micróglia promove a migração de células tumorais e contribui para o crescimento tumoral (ZHAI; HEPPNER; TSIRKA, 2011). Fatos estes que ajudam a explicar o termo "gliomaassociated micróglia/macrophages" (GAM), que se refere à micróglia/macrófagos associados ao glioma. Células tumorais recrutam ativamente os GAMs através de moléculas de sinalização como citocinas, aumentando assim o crescimento do tumor, invasão, angiogênese e imunossupressão (DA FONSECA; BADIE, 2013). Sob a influência do glioma, as células microgliais não apresentam o seu papel natural na defesa imunológica. Ao contrário, adquirem o fenótipo ativado alternativo, chamado de M2, que se caracteriza por mudanças na expressão de receptores e na produção de citocinas, alterações que coletivamente proporcionam um microambiente favorável à gliomagênese (LI; GRAEBER, 2012).

\section{Kv 10.1 no câncer}

Canais iônicos são proteínas que, inseridas na membrana plasmática, desenvolvem um papel importante no funcionamento e na homeostase das células. Possuem a função de regular o fluxo de íons $\left(\mathrm{Na}^{+}, \mathrm{K}^{+}, \mathrm{Ca}^{2+}, \mathrm{Cl}^{-}\right)$através da bicamada lipídica (HILLE, 1978).

Oficialmente denominado de Kv 10.1, mas também conhecido como Eag1, este canal de potássio foi inicialmente clonado a partir de mioblastos em cultura. O Kv 10.1 é membro da família de canais de $\mathrm{K}^{+}$dependentes de voltagem (Kv) (GUTMAN et al., 2005; OCCHIODORO et al., 1998). São constituídos por estrutura tetramérica. Cada uma 
das quatro $\alpha$-subunidades é composta por seis domínios transmembrana (S1-S6). A região do poro (P) está localizada entre os domínios S5 e S6. Possuem regiões terminais, amino $(\mathrm{N})$ e carboxila $(\mathrm{C})$, localizadas no citoplasma. $\mathrm{O}$ terminal $\mathrm{N}$ consiste de um domínio per-Arnt-Sim (PAS), que funciona como um sensor de hipóxia. Este sensor é capaz de ativar o fator HIF1 $\alpha$ (hypoxia-inducible factor $1 \alpha$ ), promovendo a angiogênese e, consequentemente, favorecendo o crescimento de células tumorais em um ambiente hipóxico (DOWNIE et al., 2008). Já o terminal C contém o domínio de ligação de nucleotídeos cíclicos (cNBD, cyclic nucleotide-binding domain), diretamente envolvido na expressão funcional dos canais de $\mathrm{K}^{+}$dependentes de voltagem (Figura 3) (ASHER et al., 2010; SCHWARZ; BAUER, 1999).

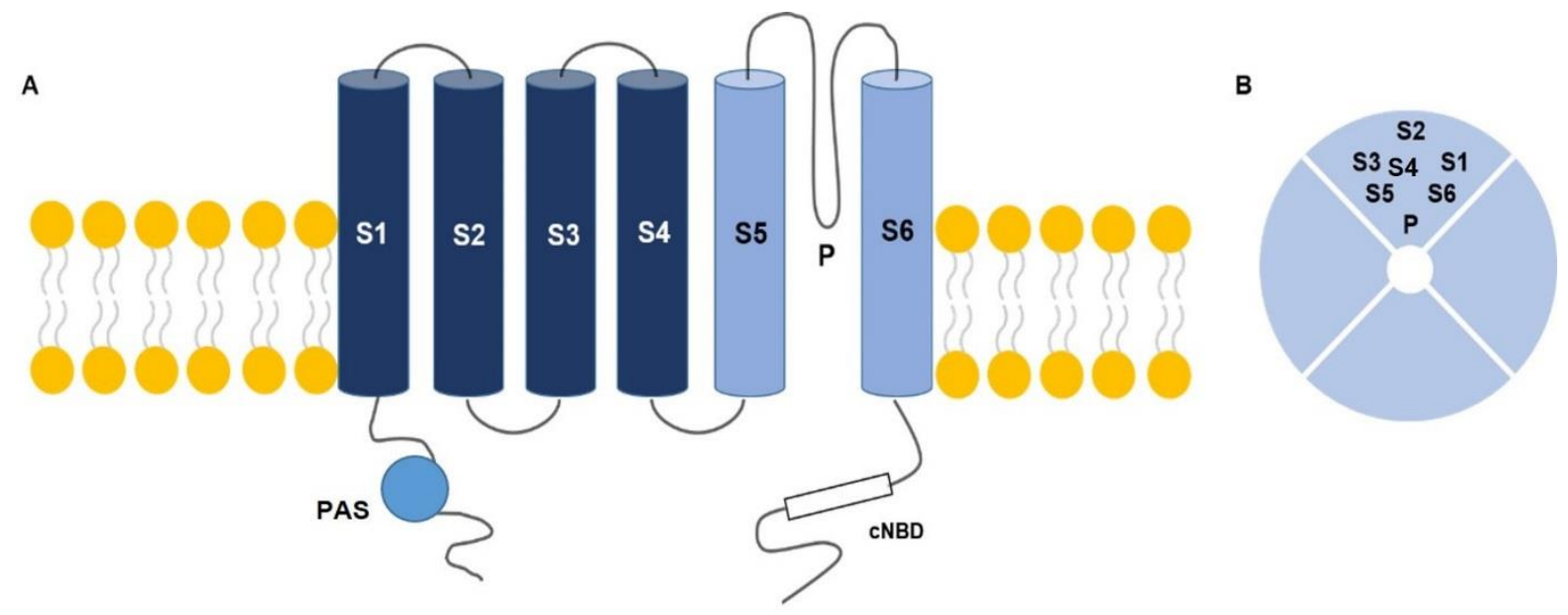

Figura 3. Representação esquemática do canal Kv 10.1. (A) $\alpha$-subunidades compostas por 6 domínios que atravessam a membrana plasmática (S1-S6). (B) estrutura composta por $4 \alpha$-subunidades e região do poro (P). Modificado (SCHWARZ; BAUER, 1999).

O papel pró-tumorigênico do Kv 10.1 foi descrito pela primeira vez em 1999 por Pardo e colaboradores, com a descoberta de que a inibição da sua expressão reduzia a proliferação celular de diversas linhagens de câncer (PARDO et al., 1999). Além disto, a expressão do canal $\mathrm{Kv} 10.1$ foi detectada em aproximadamente $70 \%$ das biópsias de tumores humanos de diversas origens (DING et al., 2007; WU et al., 2013).

No glioma, estudos anteriores revelaram que o Kv 10.1 mostrava-se hiperexpresso em amostras de tecidos tumorais de pacientes, com diferentes subtipos e graus de malignidade (PATT et al., 2004). Nenhum trabalho, entretanto, avaliou o papel do canal Kv 10.1 na comunicação de células de glioma com a micróglia associada, tema do

\section{Capítulo 2.}




\section{Efeitos da supressão do canal de potássio Kv 10.1 no câncer}

Após a detecção da expressão do Kv 10.1 em diversos tipos de câncer, estudos foram realizados com o objetivo de reduzir a proliferação celular ou o desenvolvimento tumoral. O canal Kv 10.1 pode ser inibido farmacologicamente pela imipramina e pelo astemizol (GAVRILOVA-RUCH et al., 2002), mediante o uso de anticorpos (GÓMEZVARELA et al., 2007), e também em nível pós-transcripcional por interferência de RNA (RNAi) (CUNHA et al., 2013; GONZALEZ-ALEGRE; PAULSON, 2007).

O antidepressivo tricíclico imipramina e o anti-histamínico astemizol são capazes de bloquear as funções eletrofisiológicas do $\mathrm{Kv} 10.1$, sendo que o tratamento com estes fármacos reduziu significativamente a taxa de proliferação celular em tumores mamários e melanomas (GARCÍA-QUIROZ; CAMACHO, 2011; GARCÍA-QUIROZ et al., 2014; GAVRILOVA-RUCH et al., 2002; OUADID-AHIDOUCH et al., 2001). No entanto, ambos os fármacos são inespecíficos e não seletivos, podendo causar efeitos colaterais (SANGUINETTI; TRISTANI-FIROUZI, 2006).

Pesquisadores liderados pelo Prof. Dr. Luis Pardo, do Instituto Max Planck for Experimental Medicine - Göttingen, desenvolveram o primeiro anticorpo monoclonal contra o canal Kv 10.1 (mAb56) capaz de inibi-lo imunologicamente (GÓMEZVARELA et al., 2007). O estudo demonstrou que o anticorpo reduziu a corrente de íons $\mathrm{K}^{+}$no canal $\mathrm{Kv} 10.1$ em células isoladas e não provocou qualquer alteração sobre os canais Eag2 e hERG, mostrando-se seletivo. Dessa forma, houve a inibição do crescimento de células de diferentes linhagens tumorais humanas. Porém, o mAb56 não foi eficaz em todas as linhagens celulares testadas (GÓMEZ-VARELA et al., 2007; PARDO; STÜHMER, 2008; ZHOU; MA; HUANG, 1998).

No tocante à interferência de RNA (RNAi), esta é uma estratégia de degradação parcial ou total de um RNA mensageiro (RNAm) alvo, por meio de sequências curtas de nucleotídeos (TIEMANN; ROSSI, 2009). O processo pode ser desencadeado experimentalmente mediante o uso siRNAs ou vetores de expressão. Este mecanismo celular é composto de duas etapas (Figura 4). No presente estudo, os grampos curtos expressos pelo vetor pKv10.1-3 são clivados dentro da célula em fragmentos de 21 - 23 nucleotídeos pela enzima nuclease Dicer. Em seguida, os pequenos fragmentos de dsRNA conhecidos como small interfering RNAs (siRNAs) se associam a proteínas celulares formando um complexo chamado RISC (RNA Induced Silencing Complex). Uma enzima presente no complexo abre a dupla-fita dos siRNAs e elimina uma das fitas (denominada 
passenger), permanecendo a fita guide (antisense), que irá guiar o complexo RISC até o RNAm alvo para posterior degradação (ALTON, 2007). Como resultado deste processo, ocorre a redução do conteúdo da proteína de interesse, tanto in vitro como in vivo. $\mathrm{O}$ tratamento com siRNAs (small interfering RNA), direcionados ao $\mathrm{Kv} 10.1$, resultou na redução do nível celular de RNAm e da proliferação em linhagens de células de câncer, tais como glioblastoma multiforme (U138 MG), rabdomiossarcoma (TE-671, A204), fibrossarcoma (HT1080, Hs633t), câncer de mama (MCF-7, MDA-MB435S), melanoma (IGR39, IPC298), câncer de colo do útero (HeLa), neuroblastoma (SH-SY5Y) e meduloblastoma (Daoy) (CUNHA et al., 2013; WEBER et al., 2006). Esses estudos apontam para o potencial do Kv 10.1 como um alvo para a terapia do câncer.

O silenciamento gênico do Kv 10.1 pelo uso de shRNAs (short hairpin RNA) inibiu a formação e proliferação de colônias de células de osteossarcoma (MG-63), reduzindo a taxa de crescimento e progressão do ciclo celular. Nos experimentos in vivo, mostrou inibição do crescimento de osteossarcoma no modelo de xenoenxerto em camundongo nude (WU et al., 2014). A interferência de RNA mediada por vetor de expressão shRNA foi um dos objetos do atual estudo. Portanto, desenvolvemos um vetor plasmidial capaz de expressar shRNAs, que tem como alvo o RNAm do canal de potássio Kv 10.1, chamado pKv10.1-3. Em estudo anterior realizado pelo nosso grupo, este vetor de expressão reduziu a viabilidade das células de glioma e potencializou efeitos do interferon-gama (CUNHA et al., 2013). Dessa forma, o silenciamento da expressão dos canais $\mathrm{Kv} 10.1$ pode ser potencialmente usado em associação com o agente quimioterápico clássico, a TMZ, conforme abordaremos no Capítulo 3.

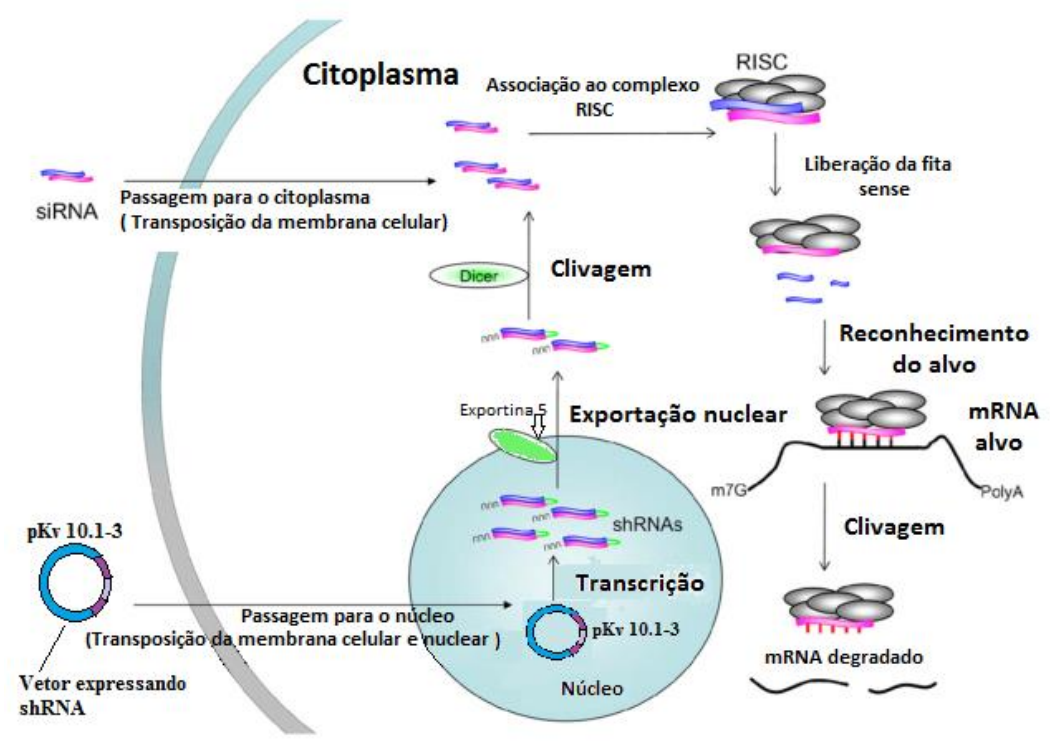


Figura 4. Esquema ilustrativo dos eventos de interferência de RNA (RNAi), adaptado de Takahashi et al., (2009). Os shRNAs são transcritos a partir de vetores de expressão (ex.: pKv 10.1-3) e exportados ao citoplasma da célula pela proteína exportina 5. São processados pela enzima Dicer e incorporados ao sistema enzimático RISC (RNA-induced silencing complex). A seguir a fita sense - passenger - (na cor roxa) é eliminada e a fita antisense - guide, representada em rosa, terá o papel de reconhecer a sequência de RNAm alvo (Ex.: Kv 10.1) e "guiar” o complexo RISC a ele, que será posteriormente degradado. Os siRNAs são RNAs exógenos curtos, e em dupla fita, que podem ser transfectados para o interior das células e diretamente incorporados ao complexo RISC, sem a necessidade de um vetor de expressão.

\section{Abordagens metodológicas inovadoras}

\section{Camundongo transgênico TgH(CX3CR1-EGFP) e células de glioma GL261mCherry}

Os camundongos transgênicos utilizados no presente estudo denominam-se TgH(CX3CR1-EGFP). Nestes animais, a expressão do gene CX3CR1 murino (presente em monócitos do sangue periférico, subconjuntos de células NK, células dendríticas e a micróglia do cérebro) está vinculada à expressão conjunta da proteína verde fluorescente melhorada (EGFP) (JUNG et al., 2000). O locus CX3CR1 mutante contém o gene de EGFP em substituição dos primeiros 390 pares de nucleotídeos do segundo exon. CX3CR1 é uma proteína G transmembrânica com receptor acoplado e expresso por leucócitos, que desempenha um papel na migração e adesão celular (IMAI et al., 1997). O ligante deste receptor é chamado fractalcina (FKN) (BAZAN et al., 1997). Em síntese, o camundongo knock-in CX3CR1-EGFP apresenta uma expressão fluorescente verde no receptor FKN pelas células microgliais, fato que permitiu estudos sobre o papel da micróglia no desenvolvimento da medula espinhal e neurodegeneração (MENTEYNE et al., 2009; RIGATO et al., 2011).

Quanto à linhagem de glioma, há muitos tipos celulares disponíveis para o uso em modelos animais desta doença (CHEN et al., 2013; DAI; HOLLAND, 2001; HUSZTHY et al., 2012). A linhagem GL261, utilizada no atual estudo, é um modelo clássico de GBM, que foi desenvolvido em 1939 por indução química com metilcolantreno (MCA) em camundongos C3H (ARNOLD M. SELIGMAN, M. J. SHEAR, 1939). A partir daí o modelo foi mantido pelo transplante de fragmentos do tumor para outros hospedeiros singeneicos, no caso a linhagem C57BL/6 de camundongo. Na década de 1990 foi então 
estabelecida a linhagem celular permanente GL261 (AKBASAK; OLDFIELD; SARIS, 1991). Este modelo apresenta uma vantagem notável: o tumor cresce em animais com sistema imune intacto. Como a GL261 não requer o uso de animais do tipo "nude", os resultados obtidos no modelo animal se aproximam mais ao glioblastoma humano $(\mathrm{OH}$ et al., 2014). Avaliando como as células microgliais se comportam na presença de gliomas implantados, esse modelo torna-se muito relevante. Assim, a GL261 foi amplamente utilizada em pesquisas sobre imunoterapia e, além disso, em muitos estudos sobre a biologia do glioma (MAES; VAN GOOL, 2011). O modelo que utiliza as células GL261 em camundongos mostra padrões semelhantes aos encontrados no GBM humano, como segue: morfologia semelhante das células, fenótipo invasivo no cérebro normal e mutações genéticas que sinaliza a desregulação de vias de expressão gênica responsáveis pela proliferação celular, bem como um quadro característico de estágios de formação de tumores no homem (JACOBS et al., 2011; MAES; VAN GOOL, 2011; OH et al., 2014).

Estudos anteriores já haviam utilizado o modelo GL261 para examinar como as interações micróglia-glioma afetam o desenvolvimento do tumor. Gliomas influenciam a micróglia para expressar metaloprotease do tipo 1, presente na membrana celular, o que contribui para a expansão dos tumores (MARKOVIC et al., 2009). Os autores utilizaram imagens em série de áreas afetadas por tumores para produzir uma imagem tridimensional, o que revelou a presença de células microgliais na vizinhança do tumor implantado. Um outro estudo com o fármaco ganciclovir, capaz de reduzir o número de células da micróglia no interior do tecido tumoral, causou diminuição acentuada no crescimento do tumor, o que confirma que a micróglia contribui para gliomagênese (ZHAI; HEPPNER; TSIRKA, 2011). Em comum, ambos os estudos utilizaram um modelo de camundongo com base em células GL261 expressando GFP. Além disso, detectaram aumento microglial e infiltração tumoral por detecção da proteína Iba1 (ionized calcium-binding adapter molecule 1) através de imunohistoquímica. Em todos os casos, é mostrado que dois tipos de células distintas poderiam exercer influências recíprocas que contribuam para a expansão do tumor.

\section{Microscopia de varredura tipo 2-photon - Laser Scanning Microscopy (2P-LSM)}

Um tipo específico de microscopia foi utilizado neste estudo para obtenção das imagens do camundongo implantado com as células tumorais. Trata-se do 2P-LSM, 
tecnologia que faz uso da detecção de fluorescência por absorção de dois fótons em um corante expresso intrinsicamente por uma população celular alvo que foi geneticamente modificada, no caso o camundongo $\mathrm{TgH}(\mathrm{CX} 3 \mathrm{CR} 1-\mathrm{EGFP})$ com células da micróglia fluorescentes e as células de glioma GL261, geneticamente modificadas para expressar a proteína fluorescente mCherry. Esta abordagem trouxe várias vantagens para imagens de fluorescência, possibilitando o escaneamento in vivo de células e tecidos (RUBART, 2004). Em comparação com a microscopia confocal clássica, o método proporciona um aumento de 100 vezes na penetração dos feixes de luz, o que é valioso para estudos sobre os tecidos cerebrais (CENTONZE; WHITE, 1998; LEVENE et al., 2004). Além disso, o 2P-LSM discrimina sinais fluorescentes em uma escala submicrométrica, com intensidade de sinal suficiente em profundidades maiores (OHEIM et al., 2001). Com o método, é possível construir uma imagem tridimensional de ótima qualidade de uma região do córtex, por exemplo. Eventos sequenciais podem, ainda, serem gravados no mesmo espécime em períodos prolongados. Na neurociência, o uso do 2P-LSM tem permitido diversos estudos sobre o desenvolvimento do sistema nervoso, fisiologia celular, plasticidade, e degeneração neuronal (DIBAJ et al., 2011; KASISCHKE et al., 2004; LICHTMAN; FRASER, 2001; SVOBODA; TANK; DENK, 1996).

\section{Referências bibliográficas}

AKBASAK, A.; OLDFIELD, E. H.; SARIS, S. C. Expression and modulation of major histocompatibility antigens on murine primary brain tumor in vitro. Journal of neurosurgery, v. 75, n. 6, p. 922-9, 19 dez. 1991.

ALOISI, F. Immune function of microglia. Glia, v. 36, n. 2, p. 165-79, nov. 2001.

ALTON, E. Progress and Prospects: Gene Therapy Clinical Trials (Part 1). Gene Therapy, v. 14, n. 20, p. 1439-1447, out. 2007.

ARNOLD M. SELIGMAN, M. J. SHEAR, L. A. Studies in Carcinogenesis: VIII. Experimental Production of Brain Tumors in Mice with Methylcholanthrene. The American Journal of Cancer, v. 37, p. 364-395, 1939.

ASHER, V. et al. Eag and HERG potassium channels as novel therapeutic targets in cancer. World journal of surgical oncology, v. 8, p. 113, 2010.

BAZAN, J. F. et al. A new class of membrane-bound chemokine with a CX3C motif. Nature, v. 385, n. 6617, p. 640-4, 13 fev. 1997.

BECHMANN, I.; NITSCH, R. Plasticity following lesion: help and harm from the immune system. Restorative neurology and neuroscience, v. 19, n. 3-4, p. 189-98, jan. 2001. 
CARSON, M. J. Microglia as liaisons between the immune and central nervous systems: functional implications for multiple sclerosis. Glia, v. 40, n. 2, p. 218-31, nov. 2002.

CENTONZE, V. E.; WHITE, J. G. Multiphoton excitation provides optical sections from deeper within scattering specimens than confocal imaging. Biophysical journal, v. 75, n. 4, p. 2015-24, out. 1998.

CHEN, L. et al. Vertebrate animal models of glioma: understanding the mechanisms and developing new therapies. Biochimica et biophysica acta, v. 1836, n. 1, p. 158-65, ago. 2013.

CUNHA, L. C. et al. RNA interference with EAG1 enhances interferon gamma injury to glioma cells in vitro. Anticancer research, v. 33, n. 3, p. 865-70, mar. 2013.

DA FONSECA, A. C. C.; BADIE, B. Microglia and macrophages in malignant gliomas: recent discoveries and implications for promising therapies. Clinical \& developmental immunology, v. 2013, p. 264124, jan. 2013.

DAI, C.; HOLLAND, E. C. Glioma models. Biochimica et biophysica acta, v. 1551, n. 1, p. M19-27, 31 ago. 2001.

DAVALOS, D. et al. ATP mediates rapid microglial response to local brain injury in vivo. Nature neuroscience, v. 8, n. 6, p. 752-8, jun. 2005.

DENNY, B. J. et al. NMR and Molecular Modeling Investigation of the Mechanism of Activation of the Antitumor Drug Temozolomide and Its Interaction with DNA. Biochemistry, v. 33, n. 31, p. 9045-9051, ago. 1994.

DIBAJ, P. et al. In vivo imaging reveals rapid morphological reactions of astrocytes towards focal lesions in an ALS mouse model. Neuroscience letters, v. 497, n. 2, p. 14851, 22 jun. 2011.

DILGER, R. N.; JOHNSON, R. W. Aging, microglial cell priming, and the discordant central inflammatory response to signals from the peripheral immune system. Journal of leukocyte biology, v. 84, n. 4, p. 932-9, out. 2008.

DING, X.-W. et al. Aberrant expression of ether à go-go potassium channel in colorectal cancer patients and cell lines. World journal of gastroenterology, v. 13, n. 8, p. 125761, 28 fev. 2007.

DOWNIE, B. R. et al. Eag1 expression interferes with hypoxia homeostasis and induces angiogenesis in tumors. The Journal of biological chemistry, v. 283, n. 52, p. 3623440, 26 dez. 2008.

FU, R. et al. Phagocytosis of Microglia in the Central Nervous System Diseases. Molecular Neurobiology, v. 49, n. 3, p. 1422-1434, 7 jun. 2014.

GARCÍA-QUIROZ, J. et al. In vivo dual targeting of the oncogenic Ether-à-go-go-1 potassium channel by calcitriol and astemizole results in enhanced antineoplastic effects in breast tumors. BMC cancer, v. 14, p. 745, 2014.

GARCÍA-QUIROZ, J.; CAMACHO, J. Astemizole: an old anti-histamine as a new promising anti-cancer drug. Anti-cancer agents in medicinal chemistry, v. 11, n. 3, p. 307-14, mar. 2011.

GAVRILOVA-RUCH, O. et al. Effects of imipramine on ion channels and proliferation 
of IGR1 melanoma cells. The Journal of membrane biology, v. 188, n. 2, p. 137-49, 15 jul. 2002.

GÓMEZ-VARELA, D. et al. Monoclonal antibody blockade of the human Eag1 potassium channel function exerts antitumor activity. Cancer research, v. 67, n. 15, p. 7343-9, 1 ago. 2007.

GONZALEZ-ALEGRE, P.; PAULSON, H. L. Technology insight: therapeutic RNA interference--how far from the neurology clinic? Nature clinical practice. Neurology, v. 3, n. 7, p. 394-404, jul. 2007.

GUTMAN, G. A. et al. International Union of Pharmacology. LIII. Nomenclature and molecular relationships of voltage-gated potassium channels. Pharmacological reviews, v. 57, n. 4, p. 473-508, dez. 2005.

HILLE, B. Ionic channels in excitable membranes. Current problems and biophysical approaches. Biophysical Journal, v. 22, n. 2, p. 283-294, maio 1978.

HUSZTHY, P. C. et al. In vivo models of primary brain tumors: pitfalls and perspectives. Neuro-oncology, v. 14, n. 8, p. 979-93, ago. 2012.

IMAI, T. et al. Identification and molecular characterization of fractalkine receptor CX3CR1, which mediates both leukocyte migration and adhesion. Cell, v. 91, n. 4, p. 521-30, 14 nov. 1997.

JACOBS, V. L. et al. Current review of in vivo GBM rodent models: emphasis on the CNS-1 tumour model. ASN neuro, v. 3, n. 3, p. e00063, jan. 2011.

JESSEN, K. R. Glial cells. The international journal of biochemistry \& cell biology, v. 36, n. 10, p. 1861-7, out. 2004.

JUNG, S. et al. Analysis of fractalkine receptor CX(3)CR1 function by targeted deletion and green fluorescent protein reporter gene insertion. Molecular and cellular biology, v. 20 , n. 11, p. 4106-14, jun. 2000.

KASISCHKE, K. A. et al. Neural activity triggers neuronal oxidative metabolism followed by astrocytic glycolysis. Science (New York, N.Y.), v. 305, n. 5680, p. 99-103, 2 jul. 2004.

KetTenmann, H. et al. Physiology of microglia. Physiological reviews, v. 91, n. 2, p. 461-553, abr. 2011.

KREUTZBERG, G. W. Microglia: a sensor for pathological events in the CNS. Trends in neurosciences, v. 19, n. 8, p. 312-8, ago. 1996.

LEVENE, M. J. et al. In vivo multiphoton microscopy of deep brain tissue. Journal of neurophysiology, v. 91, n. 4, p. 1908-12, abr. 2004.

LI, W.; GRAEBER, M. B. The molecular profile of microglia under the influence of glioma. Neuro-oncology, v. 14, n. 8, p. 958-78, ago. 2012.

LICHTMAN, J. W.; FRASER, S. E. The neuronal naturalist: watching neurons in their native habitat. Nature neuroscience, v. 4 Suppl, p. 1215-20, nov. 2001.

MADINIER, A. et al. Microglial involvement in neuroplastic changes following focal brain ischemia in rats. PloS one, v. 4, n. 12, p. e8101, jan. 2009. 
MAES, W.; VAN GOOL, S. W. Experimental immunotherapy for malignant glioma: lessons from two decades of research in the GL261 model. Cancer immunology, immunotherapy : CII, v. 60, n. 2, p. 153-60, fev. 2011.

MARKOVIC, D. S. et al. Gliomas induce and exploit microglial MT1-MMP expression for tumor expansion. Proceedings of the National Academy of Sciences of the United States of America, v. 106, n. 30, p. 12530-5, 28 jul. 2009.

MARTINO, G.; PLUCHINO, S. Neural stem cells: guardians of the brain. Nature cell biology, v. 9, n. 9, p. 1031-4, set. 2007.

MCLENDON, R. E.; HALPERIN, E. C. Is the long-term survival of patients with intracranial glioblastoma multiforme overstated? Cancer, v. 98, n. 8, p. 1745-8, 15 out. 2003.

MENTEYNE, A. et al. Predominant functional expression of Kv1.3 by activated microglia of the hippocampus after Status epilepticus. PloS one, v. 4, n. 8, p. e6770, jan. 2009.

NAGASAWA, D. T. et al. Temozolomide and other potential agents for the treatment of glioblastoma multiforme. Neurosurgery clinics of North America, v. 23, n. 2, p. 30722, ix, abr. 2012.

NEWLANDS, E. S. et al. Phase I trial of temozolomide (CCRG 81045: M\&B 39831: NSC 362856). British journal of cancer, v. 65, n. 2, p. 287-91, fev. 1992.

NIMMERJAHN, A.; KIRCHHOFF, F.; HELMCHEN, F. Resting microglial cells are highly dynamic surveillants of brain parenchyma in vivo. Science (New York, N.Y.), v. 308, n. 5726, p. 1314-8, 27 maio 2005.

OCCHIODORO, T. et al. Cloning of a human ether-a-go-go potassium channel expressed in myoblasts at the onset of fusion. FEBS letters, v. 434, n. 1-2, p. 177-82, 28 ago. 1998.

$\mathrm{OH}$, T. et al. Immunocompetent murine models for the study of glioblastoma immunotherapy. Journal of translational medicine, v. 12, n. 1, p. 107, 29 abr. 2014.

OHEIM, M. et al. Two-photon microscopy in brain tissue: parameters influencing the imaging depth. Journal of neuroscience methods, v. 111, n. 1, p. 29-37, 15 out. 2001.

OSTROM, Q. T. et al. CBTRUS statistical report: Primary brain and central nervous system tumors diagnosed in the United States in 2006-2010. Neuro-oncology, v. 15 Suppl 2, p. ii1-56, nov. 2013.

OUADID-AHIDOUCH, $\mathrm{H}$. et al. Changes in the $\mathrm{K}+$ current-density of MCF-7 cells during progression through the cell cycle: possible involvement of a h-ether.a-gogo $\mathrm{K}+$ channel. Receptors \& channels, v. 7, n. 5, p. 345-56, 2001.

PARDO, L. A; STÜHMER, W. Eag1: an emerging oncological target. Cancer research, v. 68 , n. 6 , p. 1611-3, 15 mar. 2008.

PARDO, L. A. et al. Oncogenic potential of EAG K(+) channels. The EMBO journal, v. 18, n. 20 , p. $5540-7,15$ out. 1999.

PATT, S. et al. Expression of ether à go-go potassium channels in human gliomas. Neuroscience Letters, v. 368, p. 249-253, 2004.

PELVIG, D. P. et al. Neocortical glial cell numbers in human brains. Neurobiology of 
aging, v. 29, n. 11, p. 1754-62, nov. 2008.

PETERS, A.; JOSEPHSON, K.; VINCENT, S. L. Effects of aging on the neuroglial cells and pericytes within area 17 of the rhesus monkey cerebral cortex. The Anatomical record, v. 229, n. 3, p. 384-98, mar. 1991.

RANSOHOFF, R. M.; PERRY, V. H. Microglial physiology: unique stimuli, specialized responses. Annual review of immunology, v. 27, p. 119-45, jan. 2009.

RICARD, D. et al. Primary brain tumours in adults. Lancet, v. 379, n. 9830, p. 1984-96, 26 maio 2012.

RIGATO, C. et al. Pattern of invasion of the embryonic mouse spinal cord by microglial cells at the time of the onset of functional neuronal networks. Glia, v. 59, n. 4, p. 67595, abr. 2011.

ROCK, R. B. et al. Role of microglia in central nervous system infections. Clinical microbiology reviews, v. 17, n. 4, p. 942-64, table of contents, out. 2004.

RUBART, M. Two-photon microscopy of cells and tissue. Circulation research, v. 95, n. 12, p. 1154-66, 10 dez. 2004.

SANGUINETTI, M. C.; TRISTANI-FIROUZI, M. hERG potassium channels and cardiac arrhythmia. Nature, v. 440, n. 7083, p. 463-9, 23 mar. 2006.

SCHWARTZ, M. et al. Microglial phenotype: is the commitment reversible? Trends in neurosciences, v. 29, n. 2, p. 68-74, fev. 2006.

SCHWARZ, J. R.; BAUER, C. K. The ether-à-go-go-Related Gene K(+) Current: Functions of a Strange Inward Rectifier. News in physiological sciences: an international journal of physiology produced jointly by the International Union of Physiological Sciences and the American Physiological Society, v. 14, p. 135-142, ago. 1999.

STUPP, R. et al. Effects of radiotherapy with concomitant and adjuvant temozolomide versus radiotherapy alone on survival in glioblastoma in a randomised phase III study: 5year analysis of the EORTC-NCIC trial. The lancet oncology, v. 10, n. 5, p. 459-66, maio 2009.

SUTTER, A.; HEKMAT, A.; LUCKENBACH, G. A. Antibody-mediated tumor cytotoxicity of microglia. Pathobiology : journal of immunopathology, molecular and cellular biology, v. 59, n. 4, p. 254-8, jan. 1991.

SVOBODA, K.; TANK, D. W.; DENK, W. Direct Measurement of Coupling Between Dendritic Spines and Shafts. Science, v. 272, n. 5262, p. 716-719, 3 maio 1996.

TAKAHASHI, Y.; NISHIKAWA, M.; TAKAKURA, Y. Nonviral vector-mediated RNA interference: Its gene silencing characteristics and important factors to achieve RNAibased gene therapy. Advanced Drug Delivery Reviews, v. 61, n. 9, p. 760-766, jul. 2009.

TENTORI, L.; GRAZIANI, G. Recent approaches to improve the antitumor efficacy of temozolomide. Current medicinal chemistry, v. 16, n. 2, p. 245-57, 2009.

TIEMANN, K.; ROSSI, J. J. RNAi-based therapeutics-current status, challenges and prospects. EMBO Molecular Medicine, v. 1, n. 3, p. 142-151, jun. 2009. 
TREMBLAY, M.-È. et al. The role of microglia in the healthy brain. The Journal of neuroscience : the official journal of the Society for Neuroscience, v. 31, n. 45, p. 16064-9, 9 nov. 2011.

WATKINS, S.; SONTHEIMER, H. Unique biology of gliomas: challenges and opportunities. Trends in neurosciences, v. 35, n. 9, p. 546-56, set. 2012.

WEBER, C. et al. Silencing the activity and proliferative properties of the human EagI Potassium Channel by RNA Interference. The Journal of biological chemistry, v. 281, n. 19, p. 13030-7, maio 2006.

WEI, J.; GABRUSIEWICZ, K.; HEIMBERGER, A. The controversial role of microglia in malignant gliomas. Clinical \& developmental immunology, v. 2013, p. 285246, jan. 2013.

WU, J. et al. Silencing of Ether à Go-Go 1 by shRNA Inhibits Osteosarcoma Growth and Cell Cycle Progression. International Journal of Molecular Sciences, v. 15, n. 4, p. 5570-5581, 1 abr. 2014.

WU, X. et al. p38 MAPK regulates the expression of ether à go-go potassium channel in human osteosarcoma cells. Radiology and oncology, v. 47, n. 1, p. 42-9, mar. 2013.

ZHAI, H.; HEPPNER, F. L.; TSIRKA, S. E. Microglia/macrophages promote glioma progression. Glia, v. 59, n. 3, p. 472-85, mar. 2011.

ZHOU, B. Y.; MA, W.; HUANG, X. Y. Specific antibodies to the external vestibule of voltage-gated potassium channels block current. The Journal of general physiology, v. 111, n. 4, p. 555-63, abr. 1998. 


\section{Objetivo geral}

Estudar aspectos da biologia do glioma referentes à infiltração e ativação microglial, bem como o papel do canal de potássio Kv 10.1.

\section{Objetivos específicos}

1. Desenvolver e validar um modelo animal para o estudo da interação gliomamicróglia;

2. Estudar o papel do canal de potássio Kv 10.1 na interação glioma-micróglia;

3. Examinar os efeitos da supressão de Kv 10.1 sobre a injúria celular de gliomas causada pela temozolomida in vitro. 


\section{Preâmbulo}

O atual preâmbulo discorre sobre a estrutura de apresentação dos resultados alcançados nos últimos quatro anos, relacionados ao desenvolvimento de nosso modelo animal e à pesquisa focada no canal de potássio Kv 10.1. Assim, estes resultados foram organizados em capítulos, sendo que cada capítulo corresponde a determinado artigo relacionado ao tema desta tese e que se correlacionam entre si. O primeiro capítulo trata do desenvolvimento do modelo GL261/CX3CR1 e dos avanços alcançados na análise da dinâmica da infiltração e ativação microglial no glioma. O seguinte trata da expressão do canal Kv 10.1 no modelo GL261/CX3CR1 e os demais ensaios que associam a expressão deste canal, pela micróglia, com a influência das células de glioma. O capítulo três enfoca os efeitos causados pela inibição de $\mathrm{Kv} 10.1$ em células tumorais tratadas com temozolomida, quimioterápico de eleição para o tratamento do glioma. Por último, pontuamos as contribuições científicas geradas pelo estudo, bem como apresentamos as

conclusões gerais acerca dos resultados obtidos durante o curso do meu doutorado. É importante lembrar que cada capítulo, como um artigo completo, já carrega sua própria discussão. Portanto, no intuito de deixar a leitura mais fluida, optamos por não criar um texto redundante sobre discussões gerais.

Finalmente, em anexo, disponibilizamos um conjunto de trabalhos paralelos que foram desenvolvidos durante o tempo de doutorado, mas que não dizem respeito ao nosso tema principal. O primeiro e o segundo anexos são trabalhos que fizeram uso da tecnologia de RNAi direcionado às células de glioma, porém focados na enzima óxido nítrico sintase neuronal (nNOS). Trata-se de um artigo científico, submetido a periódico internacional que mostra os efeitos da inibição da nNOS na viabilidade celular do glioma, e de uma patente sobre as sequências de siRNAs e insertos utilizados no artigo anterior. O anexo três é um artigo focado também nas enzimas NO sintases, mas agora sob o ponto de vista de uma lesão no disco intervertebral. O anexo quatro é composto por dois capítulos de um livro eletrônico publicado pelo grupo de pesquisa, e pelos quais fui responsável pela escrita. 


\section{Capítulo 1 - Desenvolvimento e validação de um modelo animal para o estudo da interação glioma-micróglia}

Título do artigo: Evaluation of $\operatorname{TgH}(\mathrm{CX} 3 \mathrm{CR} 1-\mathrm{EGFP})$ mice implanted with mCherry-GL261 cells as an in vivo model for morphometrical analysis of glioma-microglia interaction

$\underline{\text { Fernando F.B. Resende }}^{\text {a,b, }}{ }^{\text {Xianshu Bai }}{ }^{\mathrm{b}}$, Elaine Aparecida Del Bel ${ }^{\mathrm{c}}$, Frank Kirchhoff ${ }^{\mathrm{b}}$, Anja Scheller ${ }^{\mathrm{b}}$ and Ricardo Titze-de-Almeida ${ }^{\mathrm{a},}$.

${ }^{a}$ Laboratório de Tecnologias para Terapia Gênica, ASS 128, ICC Sul. Universidade de Brasília - UnB, Campus Darcy Ribeiro, FAV. Brasília, DF, Brasil, 70910-970.

${ }^{b}$ Molecular Physiology, Center for Integrative Physiology and Molecular Medicine (CIPMM), University of Saarland, Homburg, Germany

${ }^{c}$ Laboratório de Neurofisiologia e Biologia Molecular, Dept. Morfologia Fisiologia e Patologia Básica, FORP, Universidade de São Paulo - USP, Ribeirão Preto, SP, Brasil, 14040-904.

Publicado no Periódico BMC Cancer - Fator de impacto 3.36, qualis A1 - Medicina Veterinária.

DOI: $10.1186 / \mathrm{s} 12885-016-2118-3$ 


\section{Abstract}

Background. Glioblastoma multiforme is the most aggressive brain tumor. Microglia are prominent cells within glioma tissue and play important roles in tumor biology. This work presents an animal model designed for the study of microglial cell morphology in situ during gliomagenesis. It also allows a quantitative morphometrical analysis of microglial cells during their activation by glioma cells. Methods. The animal model associates the following cell types: 1- mCherry red fluorescent GL261 glioma cells and; 2- EGFP fluorescent microglia, present in the $\mathrm{TgH}(\mathrm{CX} 3 \mathrm{CR} 1-\mathrm{EGFP})$ mouse line. First, mCherryGL261 glioma cells were implanted in the brain cortex of TgH(CX3CR1-EGFP) mice. Epifluorescence - and confocal laser-scanning microscopy were employed for analysis of fixed tissue sections, whereas two-photon laser-scanning microscopy (2P-LSM) was used to track tumor cells and microglia in the brain of living animals. Results. Implanted mCherry-GL261 cells successfully developed brain tumors. They mimic the aggressive behavior found in human disease, with a rapid increase in size and the presence of secondary tumors apart from the injection site. As tumor grows, mCherry-GL261 cells progressively lost their original shape, adopting a heterogeneous and diffuse morphology at $14-18 \mathrm{~d}$. Soma size increased from 10 to $52 \mu \mathrm{m}$. At this point, we focused on the kinetics of microglial access to glioma tissues. 2P-LSM revealed an intense microgliosis in brain areas already shortly after tumor implantation, i.e. at 30 minutes. By confocal microscopy, we found clusters of microglial cells around the tumor mass in the first 3 days. Then cells infiltrated the tumor area, where they remained during all the time points studied, from 6 to 18 days. Microglia in contact with glioma cells also present changes in cell morphology, from a ramified to an amoeboid shape. Cell bodies enlarged from $366 \pm 0.0 \mu \mathrm{m}^{2}$, in quiescent microglia, to $1310 \pm 146.0 \mu \mathrm{m}^{2}$, and the cell processes became shortened. Conclusions. The GL261/CX3CR1 mouse model reported here is a valuable tool for imaging of microglial cells during glioma growth, either in fixed tissue sections or living animals. Remarkable advantages are the use of immunocompetent animals and the simplified imaging method without the need of immunohistochemical procedures.

Keywords: microglia; glioma; GL261; CX3CR1; cancer; morphology; 2P-LSM. 


\section{Background}

Previous studies about glioma biology revealed that microglia is the dominant immune cell within tumor mass, accounting for about $30 \%$ of the tumor cell content (WEI; GABRUSIEWICZ; HEIMBERGER, 2013). Glioma and microglia exert reciprocal and pro-tumorigenic influences (ZHAI; HEPPNER; TSIRKA, 2011). Glioma cells stimulate microglia to express genes that favor tumor growth. A well-known example is the membrane type-1 matrix metalloproteinase (MT1-MMP), that disrupts the extracellular matrix of brain tissues, opening anatomic spaces for tumor expansion (MARKOVIC et al., 2009). Glioma cells also influence microglia to present an activated alternative phenotype; activated microglia in turn expresses pro-tumorigenic receptors and cytokines (LI; GRAEBER, 2012; SZULZEWSKY et al., 2015).

Studies on the role of microglia in glioma development have taken advantage of animal models and innovative microscopy techniques (DAI; HOLLAND, 2001; JACOBS et al., 2011; OH et al., 2014); (DONG et al., 2012; MADDEN et al., 2013; RANKIN; ZHU; BAKER, 2012). The TgH(CX3CR1-EGFP) is a mouse strain in which the fractalkine receptor gene (CX3CR1) was replaced by the green fluorescent protein (GFP) reporter gene (JUNG et al., 2000). CX3CR1 is a seven-transmembrane G-protein-coupled receptor that plays a role in leukocyte migration and adhesion (IMAI et al., 1997). Peripheral blood monocytes, subsets of natural killer cells (NK) and dendritic cells, and also microglia naturally express CX3CR1 (JUNG et al., 2000). This transgenic mouse strain (C57BL/6N background) can develop brain tumors when implanted with the GL261 cell line, an established model of glioblastoma multiforme (MAHER et al., 2001). GL261 cells do not require a suppressed immune system to generate tumors. Therefore, this feature simplifies the methodology and provides a model that represents various aspects of the human disease (AGNIHOTRI et al., 2013).

Advanced imaging techniques are also important to follow brain tumor development and microgliosis. Regarding brain imaging, two-photon laser-scanning microscopy (2P-LSM) has brought significant improvements in the fields of neuroscience and oncology. First, the method allows fluorescence imaging of cells and tissues from living animals (RUBART, 2004). Indeed, the three-dimensional images captured by 2PLSM present a 100-fold increase in penetration depth compared with confocal microscopy. This advantage is especially important for images of brain tumors recorded in vivo (CENTONZE; WHITE, 1998; LEVENE et al., 2004). 
This study reports on a glioma model dedicated to the study of microglial cells in tumor tissues. The model comprises a fluorescent glioma cell, mCherry-GL261, that was implanted in the cortex of $\operatorname{TgH}(\mathrm{CX} 3 \mathrm{CR} 1-\mathrm{EGFP})$ mice with fluorescent microglia. This GL261/CX3CR1 model allowed analysis of microglia morphology during tumor growth and morphometrical measure of parameters of microglia activation in tumor areas.

\section{Methods}

\section{Ethics statement}

This work was conducted at the University of Saarland in strict accordance to the European and German guidelines for the welfare of experimental animals under the license 65/2013, approved by the Saarland state's "Landesamt fuer Gesundheit und Verbraucherschutz" in Saarbrücken/Germany.

\section{Cell culture}

This study used the mCherry-GL261 tumor cells (VINNAKOTA et al., 2013), a glioma cell line with expression of the fluorescent protein mCherry, kindly provided by Helmut Kettenmann (Max-Delbrück-Center for Molecular Medicine, Berlin, Germany). Cells were maintained on $75 \mathrm{~cm}^{3}$ culture flasks with DMEM/F12 [supplemented with $10 \%$ (volume/volume) heat-inactivated fetal calf serum, and $1 \%$ of penicillin/streptomycin solution, all obtained from Invitrogen (Karlsruhe, Germany)]. When the confluence reached about $90 \%$, the cells were harvested using $0.25 \%$ Trypsin solution (Invitrogen, Karlsruhe, Germany). A pellet was formed by centrifugation at $1200 \mathrm{~g}$ for $3 \mathrm{~min}$ (Hettich Universal 30F, Tuttlingen, Germany). Cells were diluted in $1.0 \mathrm{ml}$ PBS and counted in Moxi-Z (Orflo, Hailey, USA). Aliquots containing $5 \times 10^{4}$ cells in PBS were made and centrifuged at $1200 \mathrm{~g}$ for $3 \mathrm{~min}$ (Eppendorf MiniSpin, Hamburg, Germany). The pellet was re-suspended in $3 \mu \mathrm{L}$ of PBS by gently mixing, and the $5 \mu \mathrm{L}$ resulting solution was immediately injected into the mouse brain by using a microliter syringe (Hamilton) with a 25 gauge needle.

\section{Mouse line}

Adult TgH(CX3CR1-EGFP) heterozygous mice (JUNG et al., 2000) backcrossed to C57BL/6N background for more than 10 generations were maintained at a temperature and light controlled animal facility, and received food and water ad libitum. 


\section{Intracortical injections of mCherry-GL261 cells}

All animals were anesthetized with Ketamine/Xylazine (Bayer, Germany) (140 mg/10 $\mathrm{mg} / \mathrm{kg}$ body weight) by intraperitoneal injection. They had the top of head shaved, and the surgery site cleaned with iodine antiseptic. Bepanthen ${ }^{\circledR}$ cream (Bayer, Germany) was used to cover and protect the eyes. After proper mouse fixation in the stereotaxic instrument, a single skin cut of about $0.5 \mathrm{~cm}$ was performed by using scissors, followed by gently divulsion of the sub-cutaneous tissue. A $2.0 \mathrm{~mm}$ hand drill (Fine Science Tools, Heidelberg, Germany) was used to thin the skull at the injection site, approximately at $2.0 \mathrm{~mm}$ posterior and $1.5 \mathrm{~mm}$ lateral of the bregma. Five microliters of the mCherryGL261 cell suspension (a total of 50.000 cells) were aspired with a micro-syringe and slowly injected, first $2.0 \mathrm{~mm}$ below skull surface into the cortex, and then the needle was pushed back $0.5 \mathrm{~mm}$ to inject the rest of the volume. About $5 \mathrm{~min}$ were spent to complete the injection and two additional min for totally removing of the needle. The sub-cutaneous tissue was gently washed with $\mathrm{NaCl}, 0.9 \%$ and the skin closed with simple interrupted sutures. Iodine antiseptic was applied on the suture after the surgery to prevent infections. Immediately afterwards, the mice were kept on a heating plate until woken up. To release the pain, buprenorphine $(0.09 \mathrm{~g} / 30 \mathrm{~g}$ body weight $)$ was administrated after the surgery and at the following day. Once the tumor cells were injected, the mice were housed individually in the same conditions as described before. For in vivo imaging, the procedure to inject the glioma cells was the same. However, after injection a cranial window was formed in the same area, to acquire the images as described below. Mice, which received injections of mCherry-GL261 cells, were daily monitored for weight and clinical status. If an animal's weight dropped 15\% below the baseline or became symptomatic, it was euthanized.

\section{Cranial window surgery}

The procedures were carried out under anesthesia initiated by Ketamine/Xylazine (Bayer, Germany) (140 mg/10 mg/kg body weight). Afterwards mice were placed on a heating pad, heads were stabilized in a stereotactic frame using ear bars, artificial ventilation was continued with a gas mixture of $\mathrm{O}_{2}(50 \%)$, and $\mathrm{N}_{2} \mathrm{O}(50 \%)$ at 120 strokes/min (100-160 $\mu 1 /$ stroke depending on the body weight). A longitudinal incision of the skin was performed between the occiput and the forehead. The subcutaneous membrane was completely removed. A $0.5 \mathrm{~mm}$ hand drill (Fine Science Tools, Heidelberg, Germany) was used to thin the skull and to open a $5.0 \mathrm{~mm}$ diameter window, approximately at 2.0 
$\mathrm{mm}$ posterior and $1.5 \mathrm{~mm}$ lateral of the bregma. The dura mater was continuously rinsed with artificial cerebro-spinal fluid: $125 \mathrm{mM} \mathrm{NaCl}, 25 \mathrm{mM} \mathrm{NaHCO}_{3}, 2.5 \mathrm{mM} \mathrm{KCl}, 1.25$ $\mathrm{KH}_{2} \mathrm{PO}_{4}, 1 \mathrm{mM} \mathrm{MgCl} 2,2 \mathrm{mM} \mathrm{CaCl}{ }_{2} * \mathrm{H}_{2} \mathrm{O}$ and $10 \mathrm{mM}$ glucose. To cover the window and make the surface flat, a $5.0 \mathrm{~mm}$ cover glass (Thermo-Scientific, Germany) was fixed by Self-Adhesive Resin Cement ESPE RelyX U200 (3M, Seefeld, Germany). In addition, the head was rigidly fixed with a custom-made clamp. The rectal body temperature was measured and kept between 36 and $38^{\circ} \mathrm{C}$ by a heating plate. The depth of anesthesia was tested by provoking the corneal reflex and reactions to noxious stimuli.

\section{Microscopic analysis}

Photographic overview images were captured using an epifluorescence microscope Axio Imager Z2 (Zeiss, Oberkochen, Germany) equipped with a 5x objective. Confocal images were taken using a laser-scanning microscope LSM-710 (Zeiss, Oberkochen, Germany) with appropriate excitation and emission filters. Z-stack images were taken at $0.8-2.0 \mu \mathrm{m}$ intervals and processed with the ZEN software (Zeiss, Oberkochen, Germany). All data were collected from three randomly selected pictures, from three different slices of at least three mice per group.

\section{Morphometric analysis of microglia based on skeletonization, measurement of cell length, soma size and Iba1 expression}

This study carried out a morphometrical analysis of microglial cells present in brain tumor tissues (region 2, tumor border, and region 3, tumor core) in comparison with the contralateral non-inoculated hemisphere (region 1). First, the number of microglial cells was counted in each region. Data included confocal stacks $(n=14)$ of $0.8-2.0 \mu$ m intervals of each individual cell, present in three randomized images of each region, in four animals. In addition, an immunohistochemical detection of Iba1 (ionized calcium binding adaptor molecule 1), a marker of microglia / macrophage, was carried out. For that, slices were first treated with a blocking solution $(0.3 \%$ Triton $\mathrm{X}-100$ and $5.0 \%$ horse serum in PBS) for $1 \mathrm{~h}$ at room temperature (RT). They were incubated with primary antibody to Iba1 (1:500, polyclonal, rabbit - Wako Chemicals, Neuss, Germany) at $4.0^{\circ} \mathrm{C}$ overnight, then washed 3 times in PBS. The fluorescent secondary antibody (AlexaFluor® 633labeled anti-mouse IgG, Invitrogen, Grand Island NY, USA), diluted 1:2000 in $2.0 \%$ horse serum in PBS, was incubated for $2 \mathrm{~h}$ at RT. After that, sequences of 14 stacks were evaluated by using the ZEN Software to determine the mean intensity value. 
For skeletonization, first, images from brain regions were acquired with a confocal microscope. Maximum intensity projections were treated to remove background noise. The images were converted to binary, presented to skeletonization, and analyzed by the ImageJ plugin AnalyzeSkeleton (ARGANDA-CARRERAS et al., 2010). The parameter end points express the complexity of microglial cell structure. It corresponds to branch ends, determined by voxels with less than two neighbors (FONTAINHAS et al., 2011; ORR et al., 2009; STENCE; WAITE; DAILEY, 2001). To measure the soma size, sequences of 14 stacks were examined with the ZEN Software (Zeiss, Oberkochen, Germany). Each microglial soma was marked with Spline contour tool, which revealed the area in $\mu \mathrm{m}^{2}$. Finally, the total length of each microglia was quantified, with the maximum intensity projections, by using the ImageJ plugin ROI manager.

\section{Two-photon laser-scanning microscopy and image acquisition}

High resolution in vivo imaging was performed using a custom-made 2P-LSM equipped with fs-pulsed titanium-sapphire laser (Chameleon Ultra II; Coherent, USA). For 2Precordings, a Zeiss W Plan Apochromat 20× (NA 1.0) water immersion objective was used. Laser excitation was set at $895 \pm 5 \mathrm{~nm}$ for EGFP and mCherry detection. Emitted light was split by a $520 \mathrm{~nm}$ longpass dichroic mirror (Semrock, Rochester, USA) and collected by photo-multiplier tubes (Hamamatsu, Japan) through two bandpass filters: a $494 \pm 20.5 \mathrm{~nm}$ (FF01-494/41-25) and a 542 $\pm 25 \mathrm{~nm}$ (FF01-542/50-25 (Semrock). In parallel, uniformly spaced $(1.5$ to $2.4 \mu \mathrm{m})$ planes of $100 * 100$ to $600 * 600 \mu \mathrm{m}^{2}$ regions were recorded, digitized and processed to obtain $\mathrm{Z}$-stacks of images $(256 \times 256$ to $1024 \times 1024$ pixels in size). Voxel sizes ranged from $0.2 \times 0.2 \times 1.5$ to $1.17 \times 1.17 \times 2.4 \mu \mathrm{m}$ for the xyz-axes. Recordings of, at most, $100 \mu \mathrm{m}$ stack depth were obtained.

\section{Statistical analysis}

All data were analyzed by using the Statistical Package for Social Sciences (IBM SPSS Statistics for Windows, Version 20. Armonk, NY) and expressed as mean \pm standard error of the mean. We used the one-way analysis of variance (ANOVA) followed by Tukey's test to test intergroup differences. Differences between pairs of experimental groups were analyzed by the Student - $t$ test. The level of statistical significance adopted was $\mathrm{p}<0.05$. 


\section{Results}

In this study, we evaluated a mouse model designed to monitor the microglial infiltration into tumor tissues and, in addition, being able to track changes in the morphology of microglia under glioma influence. All TgH(CX3CR1-EGFP) immunocompetent mice $(n=24)$ developed brain tumors within 3 to 18 days after intracortical injections of mCherry-GL261 glioma cells. This GL261/CX3CR1 model revealed the pattern of microglial infiltration into glioma tumor mass, in terms of changes in cell shape and counting, and provided data for morphometrical analysis of activated microglia.

\section{Analysis of microglial cells infiltration during glioma growth}

First, our GL261/CX3CR1 model allowed imaging of microglia and glioma cells, easily discriminated by specific fluorescence. Intracortically implanted mCherry-GL261 cells formed clusters of red-fluorescent glioma cells, as shown in Figure 1. Green-fluorescent microglia interacted with these tumors, as examined at 3,6 and 18 dpi Microglial cells presented a time- and space-dependent pattern of infiltration into developing tumor areas. In sections examined three days after inoculation, we identified microglial cells next to mCherry-GL261 cells (Fig. 1 A and D). The density of microglia close to developing glioma was higher in comparison with other brain regions. Indeed, all cells avoided to cross the tumor borders. However, six days after tumor injection, many activated microglial cells had infiltrated the tumor mass (Fig. 1 B and E). Some activated microglia also remained growing around the tumor, in close contact with glioma cells. At 18 dpi, we found an increased number of microglial cells into the enlarged and diffuse mass of glioma cells (Fig. $1 \mathrm{C}$ and F).

The mCherry-GL261 cells used in our model mimicked the typical aggressive behavior also reported in patients with glioblastoma multiforme. Tumor cells rapidly grew and infiltrated surrounding tissues. As shown in Figure $1 \mathrm{C}$, at day 18 the tumor mass compressed the left hippocampus, deforming regions CA1, CA2, CA3, and the dentate gyrus. Implanted mCherry-GL261 cells also developed secondary tumors apart from the main tumor mass, formed by cell migration or metastasis. They were present in the border of left lateral ventricle in the early 3 dpi (Fig. 1 A, red arrow). Secondary tumors also appeared at $6 \mathrm{dpi}$ in the margins of the right lateral ventricle (Fig. $1 \mathrm{~B}$, red arrows). Finally, a more prominent mass apart from the injection site developed next to hypothalamus at $18 \mathrm{dpi}$ (Fig. $1 \mathrm{C}$, red outlined arrow). 


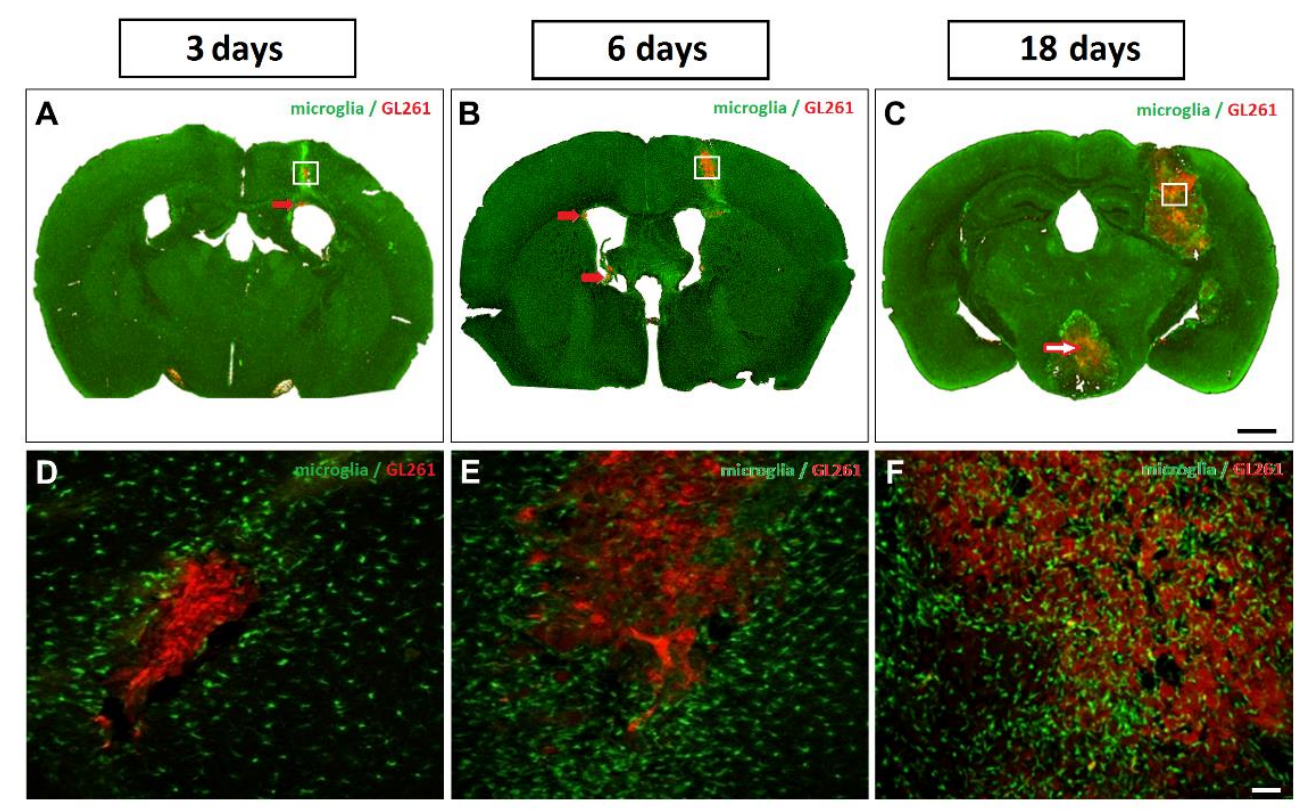

Figure 1. Epifluorescence imaging (A) 3, (B) 6 and (C) 18 dpi reveals tumor growth and metastasis. Coronal sections of a TgH(CX3CR1-EGFP) mouse brain implanted with mCherry-GL261 cells. (A and D) Glioma cells infiltrated the cortex and surrounding areas; red arrow (A) points to a secondary tumor in the left ventricle. Injection site three dpi of mCherry-GL261 cells, showing an intense microgliosis around the tumor tissue. (B and E) red arrows (B) point to secondary tumors in the right ventricle. Microglial infiltration in tumor core 6 days after injection, while microgliosis remained present in tumor border. (C and F) An enlarged and diffuse mass of glioma cells developed $18 \mathrm{dpi}$, including metastasis in the hypothalamus (red outlined arrow, C). Epifluorescence imaging in A, B and C, confocal microscopy of the region indicated by white boxes in $A-C$ in D, E and F. Scale bars: (A - C), $500 \mu \mathrm{m}$; (D - F), $100 \mu \mathrm{m}$.

\section{Tracking microglial morphological changes and quantitative cell analysis during their infiltration into the tumor mass}

The present GL261/CX3CR1 glioma model also allowed imaging of microglial cells present in tumor areas for analysis of morphology and cell density. Confocal microscopy successfully captured cell fluorescences, organized in stacks of images from fixed brain slices mounted on glass slides. We first focused on cells present in non-inoculated brain regions, like region 1 (Fig. $2 \mathrm{~A}, \mathrm{C}$, and F). These surveilling microglia showed a ramified morphology, with a small cell body and fine processes. In contrast, cells near the tumor regions assumed an amoeboid shape, a sign of microglial activation. Cell bodies were enlarged and the cellular processes displayed reduced lengths and ramifications. Amoeboid cells were present either on the borders as shown in region 2 (Fig. 2 A, D, and G) or infiltrated into the tumor core, region 3 (Fig. 2 A, E, and H) at 14 dpi.

Our model also allowed to quantify microglial cell numbers in regions 1, 2, and 3. Both tumor regions (border and core) presented a higher number of microglial cells in comparison with the contralateral brain hemisphere (Fig. 2 B, p < 0.05). In addition, cell density was significantly higher in the core region of tumors compared to the borders. These results reinforced the notion that glioma cells recruit microglia and induce its activation. 

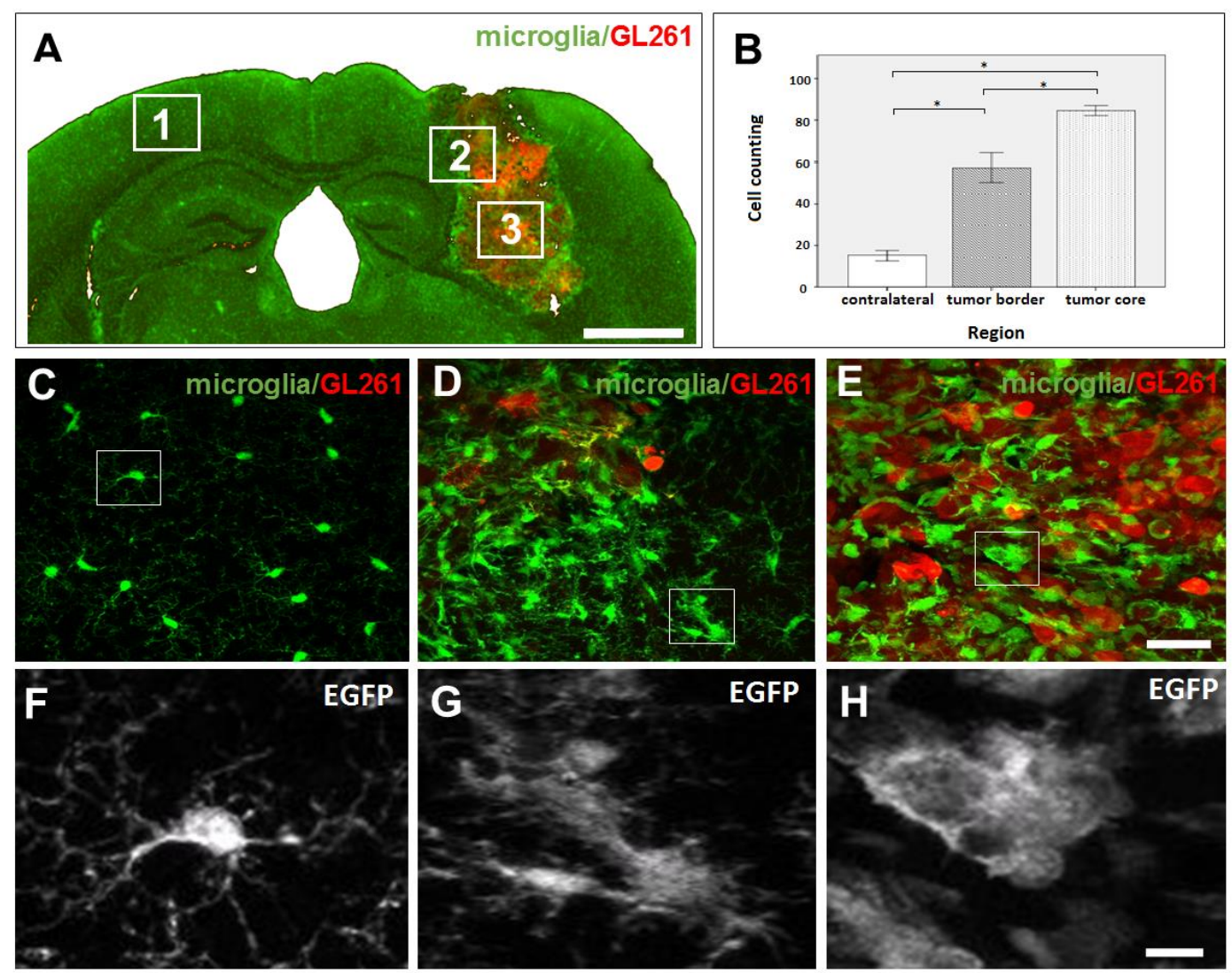

Figure 2. Analysis of microglial cells shows morphological changes depending on their location towards the tumor tissue. (A) Coronal section of a TgH(CX3CR1-EGFP) mouse brain implanted with mCherryGL261 cells at 14 dpi. White boxes indicate the following regions in analysis: 1 - contralateral hemisphere (control non-implanted site); 2 - tumor border and; 3 - tumor core. (B) Quantitative analysis of microglia cell numbers in regions $1-3$, showing an increased number of microglial cells in tumor regions 2 and 3 (border and core, respectively) in comparison with the control region $1(\mathrm{p}<0,05)$. In addition, the number increase also in the core compared to the border tumor region. $(\mathrm{C}-\mathrm{E})$ Higher magnification of the brain areas $1-3$ (white squares) in (A); maximum intensity projections acquired by confocal microscopy. $(\mathrm{F}-\mathrm{H})$ Magnified views of single cells (white boxes in $\mathrm{C}-\mathrm{E}$ ) to show details in cell morphology. In the presence of glioma cells, microglial morphology changes from a ramified $(\mathrm{C}$ and $\mathrm{F})$ to an amoeboid shape in the tumors border (D and $\mathrm{G})$ and core $(\mathrm{E}$ and H). Scale bars: $(\mathrm{A}), 500 \mu \mathrm{m} ;(\mathrm{C}-\mathrm{E}), 20 \mu \mathrm{m} ;(\mathrm{F}-\mathrm{H}), 10 \mu \mathrm{m}$.

\section{Longitudinal measure of microglial activation and morphometrical} analysis of microglia during the infiltration into tumor mass

We examined microglial cells at 14 dpi to quantify parameters of microglial activation. First, we confirmed that EGFP-positive cells of the GL261/CX3CR1 glioma model express Iba1 (Fig. 3 A - C). Iba1 is a marker of microglia/macrophages and can also indicate the activated status of microglia. Iba1 expression was higher in tumor regions in comparison with the contralateral hemisphere. The mean intensity values of anti-Iba1 were $611.4 \pm 49.0$ and $453.0 \pm 6.0$ in tumor border (Fig. 3 E) and tumor core (Fig. 3 F), respectively, in comparison with $24.8 \pm 2.8$ found in non-inoculated sites (Fig. 3 D and G; p < 0.05). 
To quantify the changes in microglial morphology, we used maximum intensity projections of confocal images (EGFP channel). We first determined the number of endpoints per cell, that represents the branch ends. Microglial cells in the border or the tumor core showed less end points (35.7 \pm 3.1 and $26.0 \pm 0.5$, respectively) in comparison with those in the contralateral control hemisphere $(108.0 \pm 16.8)$ (Fig. $3 \mathrm{H} ; \mathrm{p}<0.05)$. Microglial cells in the tumor core region also showed an enlarged soma size $\left(1310 \pm 146.0 \mu \mathrm{m}^{2}\right)$ in comparison with those in tumor borders and the contralateral hemisphere $\left(661 \pm 37.4 \mu \mathrm{m}^{2}\right.$ and $366 \pm 0.0 \mu \mathrm{m}^{2}$, respectively) (Fig. $3 \mathrm{I} ; \mathrm{p}<$ $0.05)$. Finally, the cell perimeter lengths in tumor regions $(74.3 \pm 7.0 \mu \mathrm{m}$ in tumor center and $86.7 \pm 13.4 \mu \mathrm{m}$ in the border) were smaller than those found in the contralateral control site $(268.0 \pm 38.8 \mu \mathrm{m})$ (Fig. $3 \mathrm{~J} ; \mathrm{p}<0.05)$.

In summary, our morphometric results showed that microglial cells apart from glioma tissues have a more ramified morphology. They present a higher number of thin processes extending away from their small soma. When growing next to tumor regions, cells reduced the number of processes and enlarged their soma, assuming a typical amoeboid shape. These data suggest that glioma tumors influence microglial cells to become activated and change their morphology. 

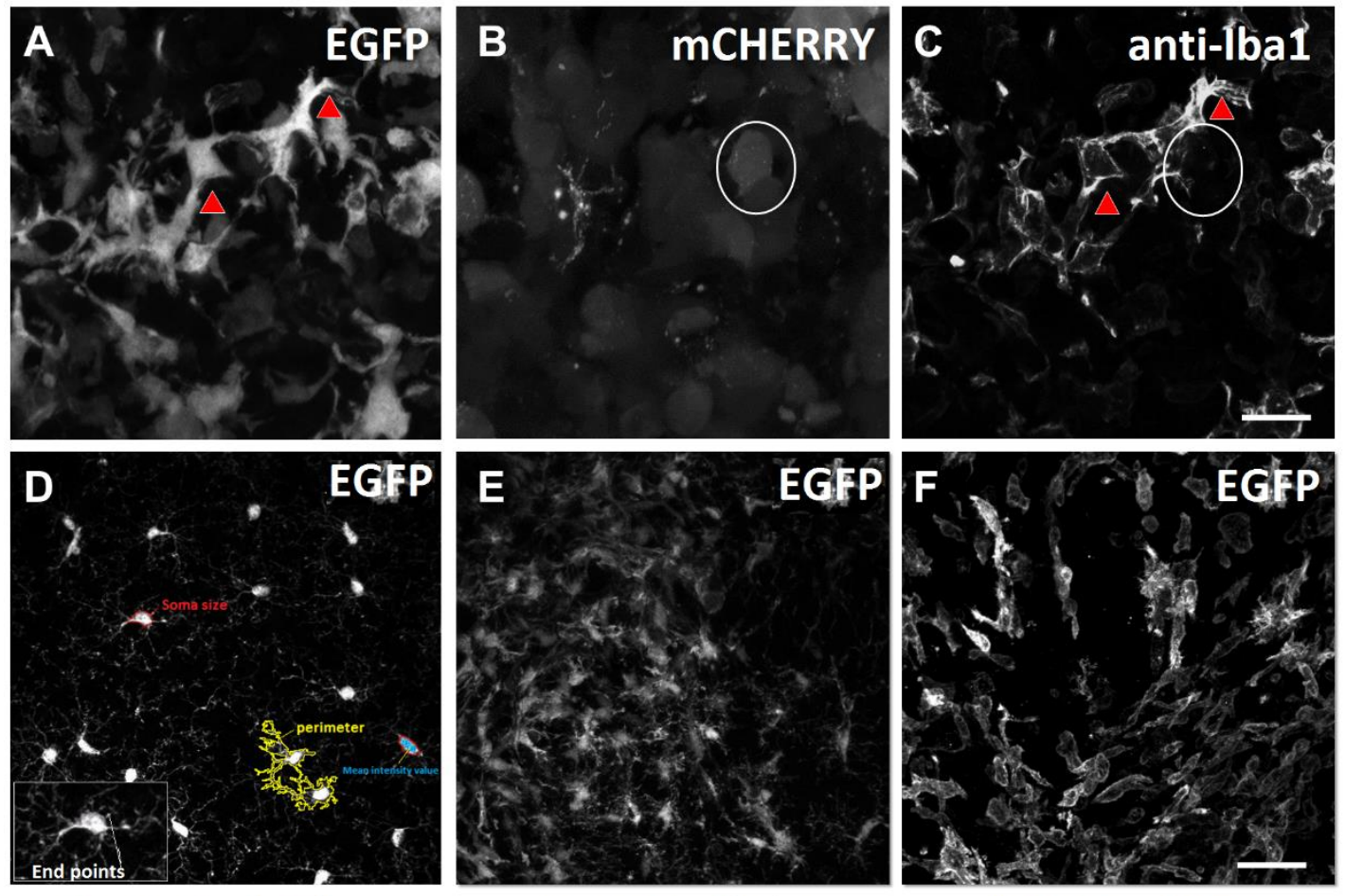

Region 1 - contralateral

Region 2 - tumor border

Region 3 - tumor core
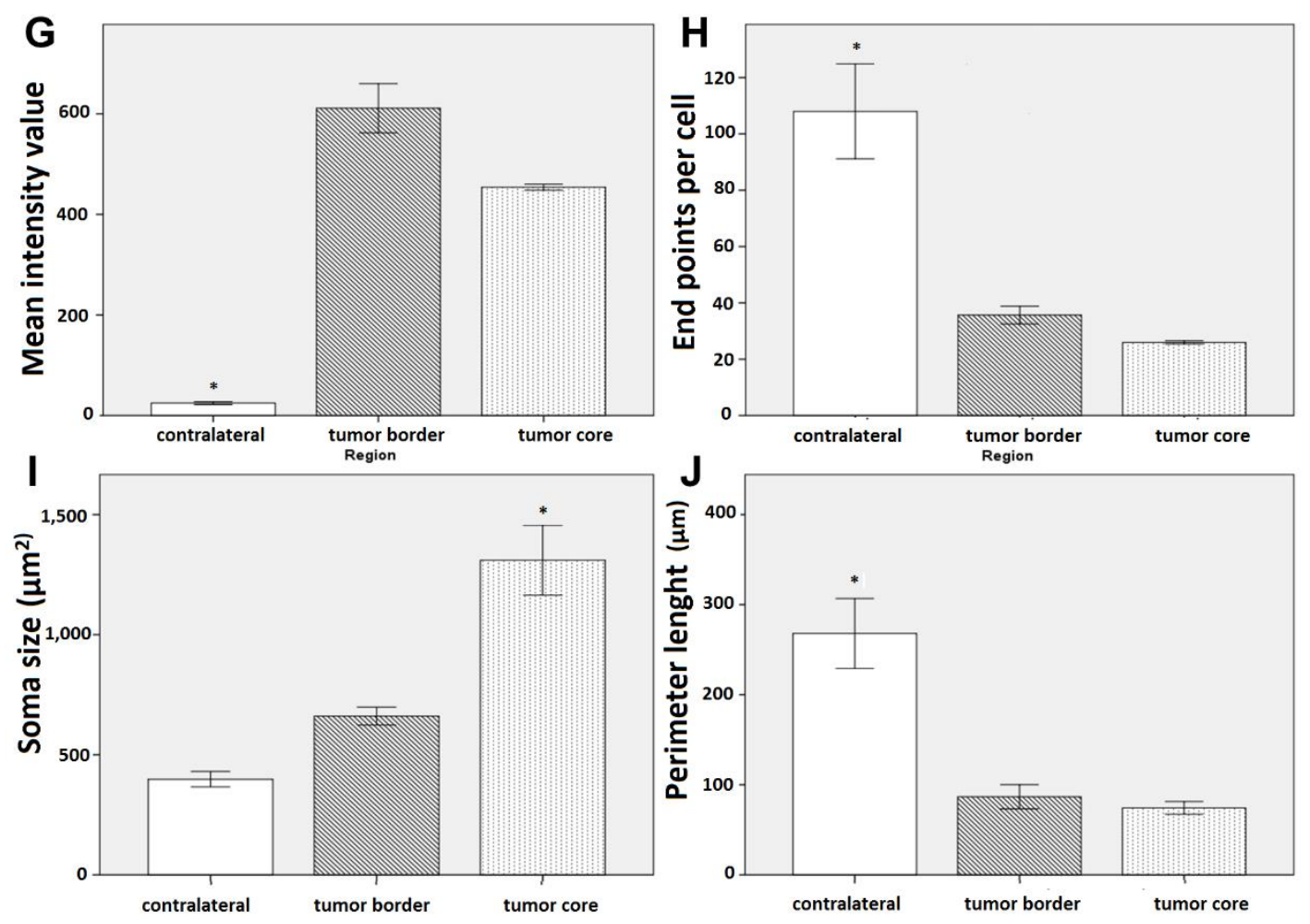

Figure 3. Quantitative morphometrical analysis of microglial activation during glioma growth reveals regional differences between core, border and control regions. Images from cortical regions implanted with glioma cells at 14 dpi. (A) Endogenous EGFP fluorescence in microglial cells (red arrowheads) in the tumor core in relation to (B) GL261 cells labeled with mCherry (white circle) were immunopositive for the microglial/macrophage marker Iba1 (C, red arrowheads). (D - F) EGFP channel of representative slices showing morphological changes in microglia, from the non-inoculated region 1 (D) to the tumor regions 2 (E) and $3(F)$. In (D), a set of parameters for morphometrical analysis of individual microglial cells is represented as follows. Blue filled in red outline: mean intensity value of Iba1 expression $(\mathrm{G})$; End points, 
the ImageJ plugin processed Skeleton tags of all pixel/voxels in a skeleton image. All junctions were classified in different categories depending on their 26 neighbors. When they had less than 2 neighbors, they were counted as end-points voxels $(\mathrm{H})$; Red contour: soma size measured in $\mu \mathrm{m}^{2}$ (I); yellow contour: total perimeter length in $\mu \mathrm{m}(\mathrm{J})$. Data were expressed as mean \pm SEM. $(* \mathrm{p}<0.05$ statistical significance, ANOVA one way followed by Tukey's test). Scale bar: $20 \mu \mathrm{m}$.

\section{Tracking the time-course of microglia and glioma cell interactions}

The time-course of microglial growth in tumor regions was examined by confocal laser scanning microscopy at 3, 6, 9, 12,14, and 18 dpi (Fig. 4 A - R). At 3 dpi, we found activated microglia (in green) surrounding glioma mCherry-GL261 cells without infiltrating the tumor mass (Fig. 4 A, B, and C). From 6 to 18 dpi, green fluorescent microglial cells infiltrated the tumor mass (in red), as shown in merge images of Fig. 4 F, I, L, O, R. Indeed, cells in close contact with glioma presented a typical activated morphology, with amoeboid shape and pseudopodia (Fig. 4, right column).

Diameter and mean intensity value of glioma cells were determined by using the ImageJ plugin ROI. For each time point, 10 cells (mCherry channel) per image, of three animals were randomly analyzed. mCherry-GL261 tumor cells displayed significant differences in cell morphology during their growth. At 3 dpi, they showed similar sizes and shapes, presenting a uniform and round shaped morphology (Fig. 4 B); diameters of cell bodies ranged from 10 to $20 \mu \mathrm{m}$. Tumors increased in size in later stages, and glioma cells assumed clear morphological changes, as occurred at 14 dpi (Fig. 4 N). The tumor core contained a population of cells heterogeneous in size and morphology; at this stage, diameters of glioma cell bodies varied from 14 to $52 \mu \mathrm{m}$. Cells also differed in fluorescence intensity as the tumor grows, ranging from 167 at 3 dpi to 626 at 14 dpi. In addition, we found an another cell type in tumor region at 12 dpi. They were polycariocytes, i.e. multinucleated cells, with a bizarre nuclei structure and enlarged cytoplasm up to $60 \mu \mathrm{m}$ of diameter (Fig. $4 \mathrm{~K}$ and L). 


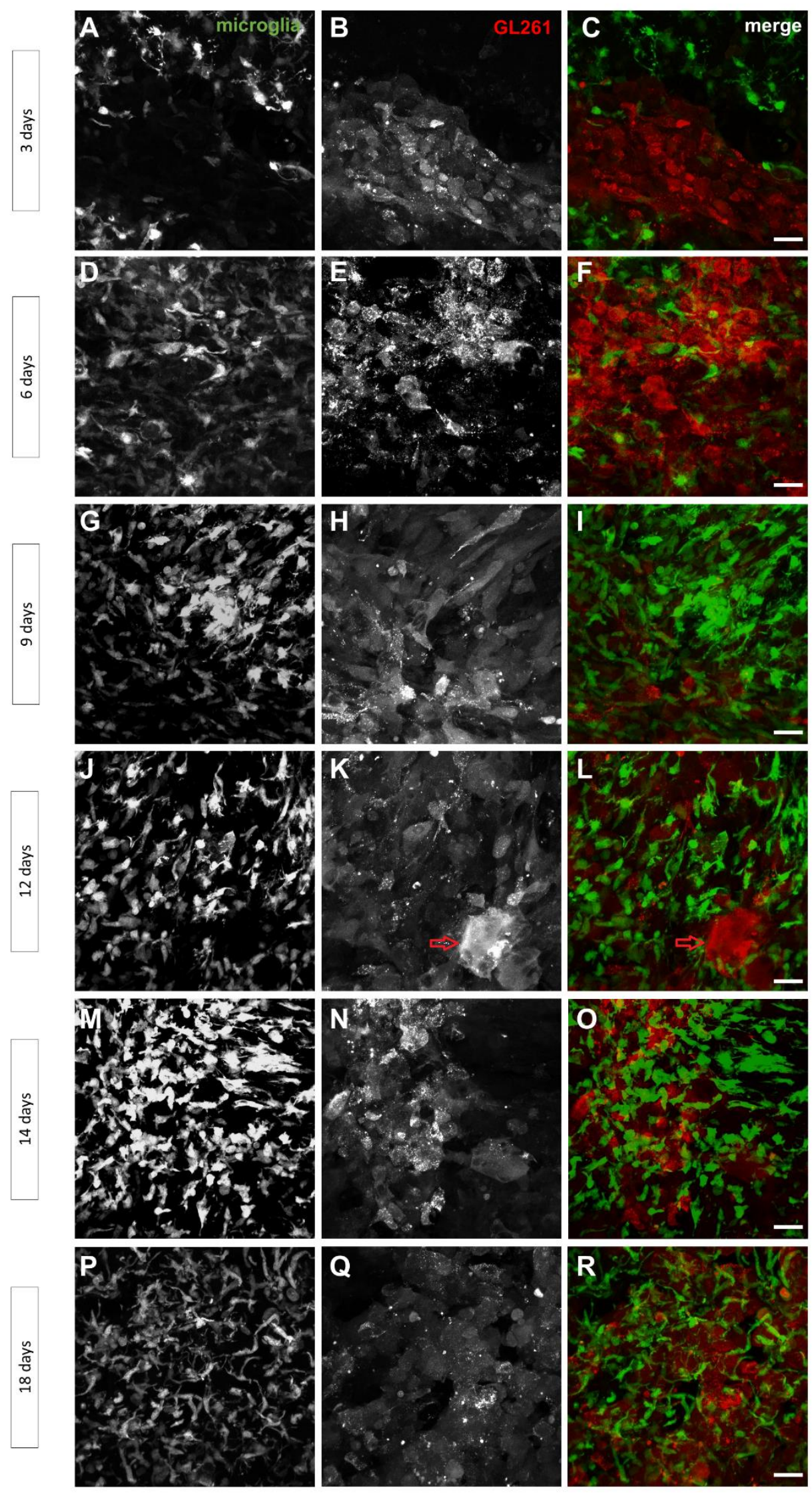


Figure 4. Observation of microglial and tumor cells reveals morphological changes in the core during gliomagenesis. (A - R) Time-course of glioma growth in mouse brain implanted with mCherry-GL261 cells 3, 6, 9, 12, 14 and 18 days after mCherry-GL261 injection in adult TgH(CX3CR1-EGFP) mice shown as maximum intensity projections of the tumor core. Channels are represented by endogenous fluorescence of EGFP in microglia (left column), mCherry in GL261 glioma cells (middle column) and merge (right column). As shown in K and L (red arrow), a polycariocytes cell appeared at 12 dpi. Scale bar: $20 \mu \mathrm{m}$.

\section{In vivo imaging by $2 \mathrm{P}$-LSM reveals the kinetics of microglial interaction with glioma cells}

The GL261/CX3CR1 model proposed in our study also provided brain tumor images of living animals. A 2P-LSM microscopy captured the fluorescence emitted by microglia and glioma cells during tumorigenesis, allowing an intravital- and noninvasive imaging. First, we could track the early stages of microglial activation. Already 30 min after injection, we noted microglia (Fig. 5 A) in close contact with mCherry-GL261 cells (Fig. $5 \mathrm{~B}$ and $\mathrm{C}$, white triangles showing glioma cells). At $36 \mathrm{~h}$, microglial cells presented different morphologies, as shown in Figure 5 D, squares. Some cells were typically amoeboid (Fig. 5 D, orange outlined square); others had a ramified morphology, with small processes (Fig. $5 \mathrm{D}$, white outlined square).

Regarding mCherry-GL261 cells, they infiltrated into the brain parenchyma and, in addition, were present at the margins of blood capillaries (Fig. 5 E and F, white arrows). This anatomic location favors the metastatic behavior of glioma cells cited above (see Fig. $1 \mathrm{C}$ ). At $36 \mathrm{~h}$ after injection, microglia remained growing in close contact with tumor cells (Fig. $5 \mathrm{G}, \mathrm{H}$ and I). 

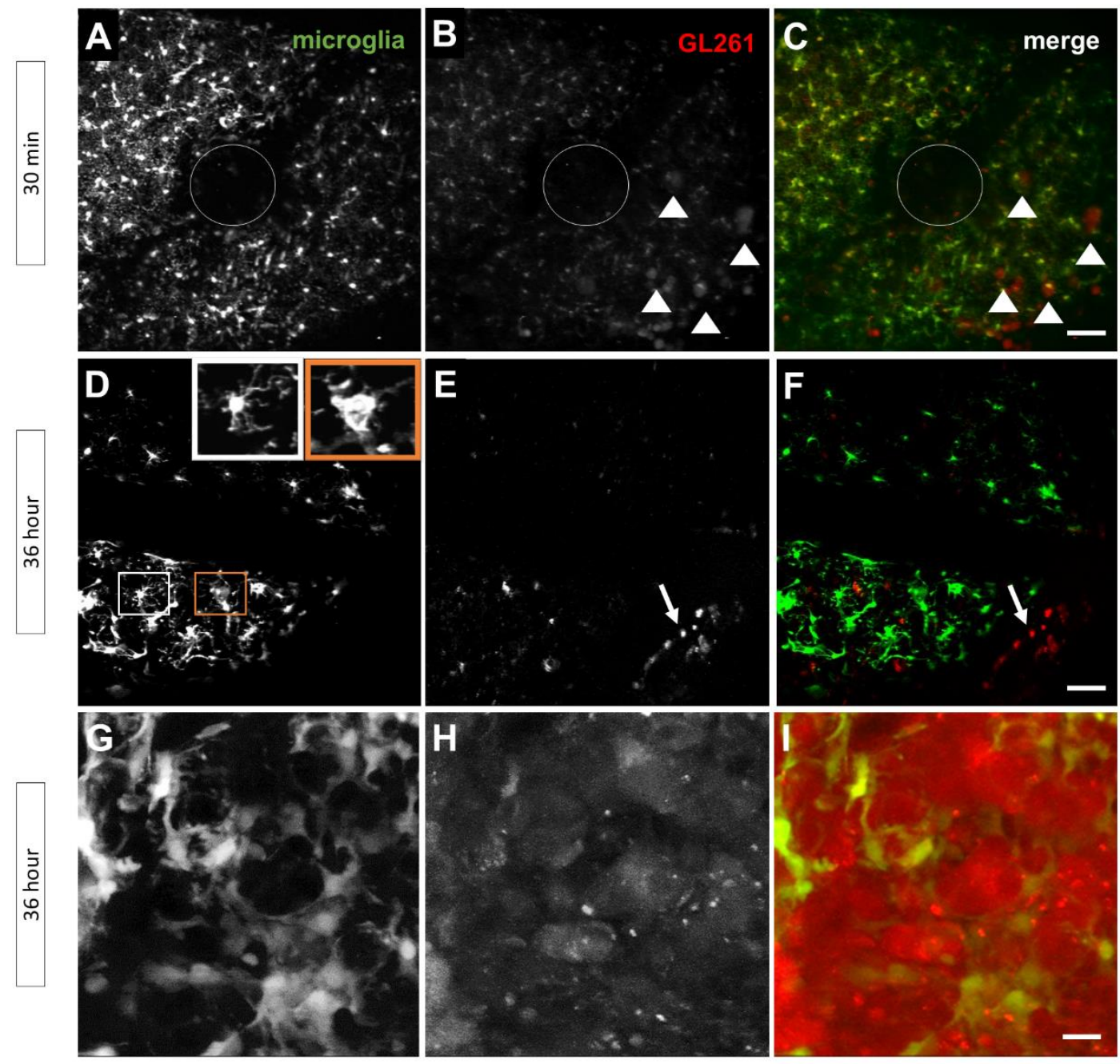

Figure 5. Two-photon laser-scanning microscopy (2P-LSM) reveals cellular responses of microglia to tumor injections in vivo in $\mathrm{TgH}(\mathrm{CX} 3 \mathrm{CR} 1-\mathrm{EGFP})$ mice. $(\mathrm{A}-\mathrm{C})$ Microgliosis around the tumor injection site (circle), $30 \mathrm{~min}$ after implantation. White triangles point to mCherry-GL261 cells infiltrating the brain cortex. (D - F) At $36 \mathrm{~h}$, microglial cells presented either a typical amoeboid shape (orange squares, D) or a ramified morphology, with a small cell body and long processes (white squares, D). mCherry-GL261 cells were present in capillary borders, suggesting a route for cancer cell spreading (white arrows, E and F). (G - I) Microglia remained infiltrated and in close contact with tumor cells, suggesting a cell-cell communication during tumor growth. Scale bars: $(A-F), 50 \mu \mathrm{m} ;(\mathrm{G}-\mathrm{I}), 20 \mu \mathrm{m}$.

\section{Discussion}

Glioblastoma multiforme (GBM) is the most aggressive and difficult to treat brain tumor (OSTROM et al., 2013; STUPP et al., 2007). To better understand glioma biology, studies have taken advantage of various animal models (AGNIHOTRI et al., 2013; CHEN; MCKAY; PARADA, 2012; MAHER et al., 2001). The cell line GL261 is a wellestablished model of GBM, developed in 1939 by chemical induction with methylcholanthrene in C3H mice (ARNOLD M. SELIGMAN, M. J. SHEAR, 1939). Injection of GL261 tumor fragments in a syngeneic host caused a glioma. A permanent 
GL261 cell line was obtained in the 1990s (AKBASAK; OLDFIELD; SARIS, 1991). Since then, GL261 cells have been used in research about immunotherapy and, in addition, in many studies addressing tumor biology (MAES; VAN GOOL, 2011). The orthotopic GL261 mouse model displays key features also found in human GBM. Cells are similar in morphology, invasive behavior and histopathological markers, presenting mutations and deregulated signaling pathways (JACOBS et al., 2011; OH et al., 2014). In our study, mCherry-GL261 cells injected into brain areas showed the typical aggressive and metastatic behavior found in patients with GBM. Three days after injection, we could note a mass of cells developing rapidly (Fig. 1). In the following days, tumor mass increased in size, compressing the hippocampus. Indeed, it spread cells to form secondary tumors in brain areas distant from the injection site, like the hypothalamus (Fig. 1 C, arrow). mCherry-GL261 cells were also found next to capillaries, suggesting blood vessels were used to spread tumor cells (Fig. $5 \mathrm{E}$ and F).

Besides recapitulating most features of human GBM, the GL261 glioma model also presents a remarkable experimental advantage - tumor grows in immunocompetent animals ( $\mathrm{OH}$ et al., 2014). Considering the biological question addressed in our study, this feature was strikingly relevant. We could examine the role of cells of the innate immune system, the microglia, in gliomas growing without immunosuppression. GL261 cell line used in our work was developed to express the mCherry fluorescence (VINNAKOTA et al., 2013). In a previous work, mCherry fluorescence was also applied to mark glioma cells. As the authors chose the U251 line, they had to use an immunosuppressed mouse line (VERREAULT et al., 2011).

Imaging of microglial cells was a critical issue in our study. In our model of glioma, we chose the TgH(CX3CR1-EGFP) mouse line, based on immunocompetent animals engineered to show fluorescent microglial cells. This mouse line was previously used to address the role of microglia in spinal cord development, during neurodegeneration and the early aspects of inflammatory response in the central nervous system (CĂTĂLIN et al., 2013; DIBAJ et al., 2010; RIGATO et al., 2011). Regarding gliomas, the $\mathrm{TgH}(\mathrm{CX} 3 \mathrm{CR} 1-\mathrm{EGFP})$ mouse strain was used to investigate aspects of tumor biology, like the role of CX3CR1 receptors in malignant glioma and a preclinical rationale for the development of stroma-directed glioma therapies in children (LIU et al., 2008, 2011; PONG et al., 2013). 
Rio-Ortega was the first to recognize microglia as a distinct population of cells in the central nervous system. He found that microglia respond to brain injury by migrating to sites of tissue damage, where cells presented marked changes in their morphology (RIO-HORTEGA, 1932). In our GL261/CX3CR1 model, microglial cells expressing EGFP allowed us to analyze and quantify that morphological changes described by RioHortega, but now during glioma development. In addition, the model allowed us to track microglial migration toward the tumor mass, and to examine the respective changes in cell morphology. The surveilling microglia - with a ramified shape and found in noninoculated areas - can become activated in tumor regions, adopting amoeboid shape.

Activation of microglia is an important change for restoring tissue integrity after injury of healthy tissues. This activation response will rapidly mitigate local infection or cell damage. During glioma development, however, microglia present a distinct role. Instead of starting the expected anti-tumor response, microglial cells switch to a protumorigenic alternative phenotype. In such conditions, microglia contributes to tumor growth, invasion, and angiogenesis. Activated microglia also cause immunosuppression by releasing cytokines/chemokines and extracellular matrix proteases (ALOISI, 2001; DA FONSECA; BADIE, 2013). This "Janus face" of microglia during gliomagenesis is still poorly understood. That results, in part, to the lack of methods able to quantify microglia activation longitudinally, in growing glioma tissues. Our study confirmed that expression of Iba1, enhanced in activated microglia, increases in tumor areas. It is a simple method to survey the cell activation in fixed brain tissues. In addition, our model also presents some advantages. It enables to examine the dynamics of microglial activation, related to changes in morphology and pattern of infiltration, after their recruitment by glioma. mCherry-GL261 cells induced changes in microglial morphology to an activated amoeboid shape. Amoeboid microglia interacted with glioma cells since the early stages of tumor growing, when glioma cells have shown a homogeneous shape. This close contact remained until the last time point of our study, $18 \mathrm{dpi}$, in which glioma tumor cells presented a highly diverse and diffuse morphology. A previous work has also reported the same change in microglia morphology in contact with glioma tumor, in brain sections obtained 15 dpi (GABRUSIEWICZ et al., 2011). Indeed, results (as shown in Fig. 2 B) corroborated the author's finding that tumor areas presented a higher microglial density compared to control brain hemispheres. 
Previous studies with the same GL261 mouse model have examined how microglia interact with glioma cells to affect tumor growing. Glioma cells could influence microglia to express a membrane type 1 metalloprotease, which contributed to tumor expansion (MARKOVIC et al., 2009). The authors organized serial images of tumor brain areas to achieve a 3-dimensionally picture of microglial cells growing around an inside tumor mass. A further study explored the effects of ganciclovir, a drug that reduced microglia cell number in tumor tissues. The treatment caused a marked decrease in tumor growing, confirming that microglia contributes to gliomagenesis (RIVEST, 2009). In common, both studies used a mouse model based on GFP-expressing GL261 cells. In addition, they detected microglial growing and tumor infiltration by Iba1 immunofluorescence. In our study, we also identified a pattern of microglia migration toward the tumor mass. First, activated microglia growth around the tumor mass, then the cells infiltrated the tumor tissue. Taking together, these data revealed that microglia and glioma cells grow in a well-organized and close spatial relationship during gliomagenesis.

Two-photon laser scanning microscopy (2P-LSM) has brought several advantages for intravital imaging of fluorescent cells (RUBART, 2004). Compared to confocal microscopy, the method offers a 100-fold increase in penetration depth, which is valuable for studies addressing brain tissues (CENTONZE; WHITE, 1998; LEVENE et al., 2004). Also, 2P-LSM discriminates fluorescent signals at a submicrometer scale, with enough signal intensity at increased depth in brain tissues (OHEIM et al., 2001). As the method offers a true three-dimensional imaging in a living organism, sequential events can be recorded in the same specimen at extended periods. In neuroscience, 2P-LSM has allowed studies on nervous system development, cell physiology, plasticity, and neuron degeneration (DENK et al., 1994; DIBAJ et al., 2011; KASISCHKE et al., 2004; LICHTMAN; FRASER, 2001; LÜTCKE; HELMCHEN, 2011; SVOBODA; TANK; DENK, 1996). Intravital microscopy of rodents engineered to express cell-specific fluorescence has provided valuable insights into mammalian biology and the mechanism of diseases (HIRRLINGER et al., 2005; NOLTE et al., 2001; WEIGERT; PORATSHLIOM; AMORNPHIMOLTHAM, 2013). In this study, the non-invasive 2P-LSM enabled an in vivo imaging of activated microglia in brain tumors of living animals. We found activated microglia contacting glioma cells shortly after tumor seeding. In 30 minutes, activated microglia have established contact with mCherry-GL261 glioma cells. 


\section{Conclusions}

The present work evaluated a GL261/CX3CR1 model, dedicated to study microglial interaction with glioma tumors. The preparation allowed to track many features of microglial activation by glioma cells, and revealed new insights into cell-cell communication in an immunocompetent mouse. Microscopy techniques and new approaches for imaging analysis provided a quantitative assessment of microglial activation and migration toward the tumor mass. GL261/CX3CR1 revealed the close contact between microglia and glioma cells, from imaging techniques that present many advantages. Cell-cell interaction was monitored: 1- longitudinally; 2- in locus; 3- with cellular resolution; 4- from fixed tissues or living animals; 5- without the need of immunodetection; 6- on timescales from minutes to weeks. In our evaluation, the method provides a rapid unbiased technique, enabling analysis of large datasets of imaging volumes taken at multiple time-points. In conclusion, GL261/CX3CR1 is a valuable model for studies about glioma-microglia interactions.

\section{List of abbreviations}

EGFP- Enhanced Green Fluorescent Protein

GFP- Green Fluorescent Protein

MT1-MMP- Membrane Type-1 Matrix Metalloproteinase

CX3CR1- Fractalkine Receptor

NK- Natural Killer cells

2P-LSM- Two-Photon Laser Scanning Microscopy

DMEM-Dulbecco's Modified Eagle's Medium

PBS- Phosphate-Buffered Saline

Iba1- Ionized Calcium Binding Adaptor Molecule 1

IgG- Immunoglobulin G

RT- Room Temperature

CA1, CA2, CA3-Cornu Ammonis areas

GBM- Glioblastoma Multiforme

dpi- days post-injection 


\section{Competing interests}

The author(s) declare that they have no competing interests.

\section{Authors' contribution}

FFBR designed the study, carried out the experiments, analyzed the data, prepared the figures and wrote the paper. $\mathrm{XB}$ and $\mathrm{AS}$ provided support in the microscopy methods, help in image analysis, figures layout and text revision. RTA, FK, AS, and EADB contributed with the study conception and design, revision of data collected and the manuscript edition. All authors read and approved the final manuscript.

\section{Acknowledgments}

The authors thank Daniel Rhode and Tamara Vogelgesang for excellent animal husbandry. The mCherry-GL261 tumor cell line was kindly provided by Helmut Kettenmann (Max Delbrück Center for Molecular Medicine, Berlin, Germany).

This work was supported by CAPES / DAAD / PROBRAL grant for the project Differentiation and regeneration potential of glial cells in acute and chronic central nervous system pathologies.

\section{References}

AGNIHOTRI, S. et al. Glioblastoma, a brief review of history, molecular genetics, animal models and novel therapeutic strategies. Archivum immunologiae et therapiae experimentalis, v. 61, n. 1, p. 25-41, fev. 2013.

AKBASAK, A.; OLDFIELD, E. H.; SARIS, S. C. Expression and modulation of major histocompatibility antigens on murine primary brain tumor in vitro. Journal of neurosurgery, v. 75, n. 6, p. 922-9, 19 dez. 1991.

ALOISI, F. Immune function of microglia. Glia, v. 36, n. 2, p. 165-79, nov. 2001.

ARGANDA-CARRERAS, I. et al. 3D reconstruction of histological sections: Application to mammary gland tissue. Microscopy research and technique, v. 73, n. 11, p. 1019-29, out. 2010.

ARNOLD M. SELIGMAN, M. J. SHEAR, L. A. Studies in Carcinogenesis: VIII. Experimental Production of Brain Tumors in Mice with Methylcholanthrene. The American Journal of Cancer, v. 37, p. 364-395, 1939.

CĂTĂLIN, B. et al. Microglia: first responders in the central nervous system. Romanian journal of morphology and embryology $=$ Revue roumaine de morphologie et embryologie, v. 54, n. 3, p. 467-72, jan. 2013. 
CENTONZE, V. E.; WHITE, J. G. Multiphoton excitation provides optical sections from deeper within scattering specimens than confocal imaging. Biophysical journal, v. 75, n. 4, p. 2015-24, out. 1998.

CHEN, J.; MCKAY, R. M.; PARADA, L. F. Malignant glioma: lessons from genomics, mouse models, and stem cells. Cell, v. 149, n. 1, p. 36-47, 30 mar. 2012.

DA FONSECA, A. C. C.; BADIE, B. Microglia and macrophages in malignant gliomas: recent discoveries and implications for promising therapies. Clinical \& developmental immunology, v. 2013, p. 264124, jan. 2013.

DAI, C.; HOLLAND, E. C. Glioma models. Biochimica et biophysica acta, v. 1551, n. 1, p. M19-27, 31 ago. 2001.

DENK, W. et al. Anatomical and functional imaging of neurons using 2-photon laser scanning microscopy. Journal of Neuroscience Methods, v. 54, n. 2, p. 151-162, out. 1994.

DIBAJ, P. et al. NO mediates microglial response to acute spinal cord injury under ATP control in vivo. GLIA, v. 58, n. 9, p. 1133-1144, 2010.

DIBAJ, P. et al. In vivo imaging reveals rapid morphological reactions of astrocytes towards focal lesions in an ALS mouse model. Neuroscience letters, v. 497, n. 2, p. 14851, 22 jun. 2011.

DONG, J. et al. Incubation and application of transgenic green fluorescent nude mice in visualization studies on glioma tissue remodeling. Chinese medical journal, v. 125, n. 24, p. 4349-54, dez. 2012.

FONTAINHAS, A. M. et al. Microglial morphology and dynamic behavior is regulated by ionotropic glutamatergic and GABAergic neurotransmission. PloS one, v. 6, n. 1, p. e15973, jan. 2011.

GABRUSIEWICZ, $K$. et al. Characteristics of the alternative phenotype of microglia/macrophages and its modulation in experimental gliomas. PLoS ONE, v. 6, n. 8, p. e23902, jan. 2011.

HIRRLINGER, P. G. et al. Expression of reef coral fluorescent proteins in the central nervous system of transgenic mice. Molecular and cellular neurosciences, v. 30, n. 3, p. 291-303, nov. 2005.

IMAI, T. et al. Identification and molecular characterization of fractalkine receptor CX3CR1, which mediates both leukocyte migration and adhesion. Cell, v. 91, n. 4, p. 521-30, 14 nov. 1997.

JACOBS, V. L. et al. Current review of in vivo GBM rodent models: emphasis on the CNS-1 tumour model. ASN neuro, v. 3, n. 3, p. e00063, jan. 2011.

JUNG, S. et al. Analysis of fractalkine receptor CX(3)CR1 function by targeted deletion and green fluorescent protein reporter gene insertion. Molecular and cellular biology, v. 20, n. 11, p. 4106-14, jun. 2000.

KASISCHKE, K. A. et al. Neural activity triggers neuronal oxidative metabolism followed by astrocytic glycolysis. Science (New York, N.Y.), v. 305, n. 5680, p. 99-103, 2 jul. 2004.

LEVENE, M. J. et al. In vivo multiphoton microscopy of deep brain tissue. Journal of neurophysiology, v. 91, n. 4, p. 1908-12, abr. 2004.

LI, W.; GRAEBER, M. B. The molecular profile of microglia under the influence of 
glioma. Neuro-oncology, v. 14, n. 8, p. 958-78, ago. 2012.

LICHTMAN, J. W.; FRASER, S. E. The neuronal naturalist: watching neurons in their native habitat. Nature neuroscience, v. 4 Suppl, p. 1215-20, nov. 2001.

LIU, C. et al. CX3CL1 and CX3CR1 in the GL261 murine model of glioma: CX3CR1 deficiency does not impact tumor growth or infiltration of microglia and lymphocytes. Journal of neuroimmunology, v. 198, n. 1-2, p. 98-105, 31 jul. 2008.

LIU, C. et al. Chemokine receptor CXCR3 promotes growth of glioma. Carcinogenesis, v. 32, n. 2, p. 129-37, fev. 2011.

LÜTCKE, H.; HELMCHEN, F. Two-photon imaging and analysis of neural network dynamics. Reports on Progress in Physics, v. 74, n. 8, p. 086602, 1 ago. 2011.

MADDEN, K. S. et al. Brain tumor imaging: live imaging of glioma by two-photon microscopy. Cold Spring Harbor protocols, v. 2013, n. 3, mar. 2013.

MAES, W.; VAN GOOL, S. W. Experimental immunotherapy for malignant glioma: lessons from two decades of research in the GL261 model. Cancer immunology, immunotherapy : CII, v. 60, n. 2, p. 153-60, fev. 2011.

MAHER, E. A. et al. Malignant glioma: genetics and biology of a grave matter. Genes \& development, v. 15, n. 11, p. 1311-33, 1 jun. 2001.

MARKOVIC, D. S. et al. Gliomas induce and exploit microglial MT1-MMP expression for tumor expansion. Proceedings of the National Academy of Sciences of the United States of America, v. 106, n. 30, p. 12530-5, 28 jul. 2009.

NOLTE, C. et al. GFAP promoter-controlled EGFP-expressing transgenic mice: a tool to visualize astrocytes and astrogliosis in living brain tissue. Glia, v. 33, n. 1, p. 72-86, jan. 2001.

$\mathrm{OH}$, T. et al. Immunocompetent murine models for the study of glioblastoma immunotherapy. Journal of translational medicine, v. 12, n. 1, p. 107, 29 abr. 2014.

OHEIM, M. et al. Two-photon microscopy in brain tissue: parameters influencing the imaging depth. Journal of neuroscience methods, v. 111, n. 1, p. 29-37, 15 out. 2001.

ORR, A. L. A. G. et al. Adenosine A(2A) receptor mediates microglial process retraction. Nature neuroscience, v. 12, n. 7, p. 872-8, jul. 2009.

OSTROM, Q. T. et al. CBTRUS statistical report: Primary brain and central nervous system tumors diagnosed in the United States in 2006-2010. Neuro-oncology, v. 15 Suppl 2, p. ii1-56, nov. 2013.

PONG, W. W. et al. Reduced microglial CX3CR1 expression delays neurofibromatosis1 glioma formation. Annals of Neurology, v. 73, n. 2, p. 303-308, 2013.

RANKIN, S. L.; ZHU, G.; BAKER, S. J. Review: insights gained from modelling highgrade glioma in the mouse. Neuropathology and applied neurobiology, v. 38, n. 3, p. 254-70, jun. 2012.

RIGATO, C. et al. Pattern of invasion of the embryonic mouse spinal cord by microglial cells at the time of the onset of functional neuronal networks. Glia, v. 59, n. 4, p. 67595, abr. 2011.

RIO-HORTEGA, P. DEL. Microglia. In Cytology and Cellular Pathology of the Nervous System. Vol. 2 ed. New York, NY: W. Penfield, 1932.

RIVEST, S. Regulation of innate immune responses in the brain. Nature reviews. 
Immunology, v. 9, n. 6, p. 429-39, jun. 2009.

RUBART, M. Two-photon microscopy of cells and tissue. Circulation research, v. 95, n. 12, p. 1154-66, 10 dez. 2004.

STENCE, N.; WAITE, M.; DAILEY, M. E. Dynamics of microglial activation: a confocal time-lapse analysis in hippocampal slices. Glia, v. 33, n. 3, p. 256-66, 1 mar. 2001.

STUPP, R. et al. Chemoradiotherapy in malignant glioma: standard of care and future directions. Journal of clinical oncology : official journal of the American Society of Clinical Oncology, v. 25, n. 26, p. 4127-36, 10 set. 2007.

SVOBODA, K.; TANK, D. W.; DENK, W. Direct Measurement of Coupling Between Dendritic Spines and Shafts. Science, v. 272, n. 5262, p. 716-719, 3 maio 1996.

SZULZEWSKY, F. et al. Glioma-Associated Microglia/Macrophages Display an Expression Profile Different from M1 and M2 Polarization and Highly Express Gpnmb and Spp1. PLOS ONE, v. 10, p. e0116644, 2015.

VERREAULT, M. et al. Development of glioblastoma cell lines expressing red fluorescence for non-invasive live imaging of intracranial tumors. Anticancer Research, v. 31, p. 2161-2171, 2011.

VINNAKOTA, K. et al. Toll-like receptor 2 mediates microglia/brain macrophage MT1MMP expression and glioma expansion. Neuro-oncology, v. 15, n. 11, p. 1457-68, nov. 2013.

WEI, J.; GABRUSIEWICZ, K.; HEIMBERGER, A. The controversial role of microglia in malignant gliomas. Clinical \& developmental immunology, v. 2013, p. 285246, jan. 2013.

WEIGERT, R.; PORAT-SHLIOM, N.; AMORNPHIMOLTHAM, P. Imaging cell biology in live animals: ready for prime time. The Journal of cell biology, v. 201, n. 7, p. 969-79, 24 jun. 2013.

ZHAI, H.; HEPPNER, F. L.; TSIRKA, S. E. Microglia/macrophages promote glioma progression. Glia, v. 59, n. 3, p. 472-85, mar. 2011. 


\section{Capítulo 2 - Sobre o papel do canal de potássio Kv 10.1 na interação micróglia - glioma}

\section{Título do artigo: Potassium channel Kv 10.1 expression in microglia-glioma interaction}

$\underline{\text { Fernando F. Borges Resende }}^{1}$; Ricardo Titze-de-Almeida ${ }^{1}$

1- Laboratório de Tecnologias para Terapia Gênica, ASS 128, ICC Sul. Universidade de Brasília - UnB, Campus Darcy Ribeiro, FAV. Brasília, DF, Brasil, 70910-970.

Artigo em desenvolvimento. Os resultados preliminares aqui apresentados servem de base para o capítulo seguinte (Capítulo 3). 


\section{Introduction}

Glioblastoma multiforme matches for $70 \%$ of all adult malignant primary brain tumors (OSTROM et al., 2013). The tumor present the highest malignancy grade, level IV, with a median survival time of about 15 months (MCLENDON; HALPERIN, 2003; STUPP et al., 2009). Therapeutic choices for patients with glioma are risky and limited. As tumor grows within brain tissues, surgical ablations represent an increased harm, and recurrence commonly occurs (WATKINS; SONTHEIMER, 2012). Indeed, chemotherapy and radiation may fail because of cancer cell resistance (NAGASAWA et al., 2012; RICARD et al., 2012). Studies on glioma biology reveal that microglia is the dominant immune cell within tumor mass and account for $30 \%$ of the tumor cell content (WEI; GABRUSIEWICZ; HEIMBERGER, 2013). Glioma and microglia exert reciprocal and pro-tumorigenic influences (ZHAI; HEPPNER; TSIRKA, 2011). Glioma cells stimulate microglia to express genes that favor tumor growing.

Microglial responses under glioma influence are affected by the activity of potassium channels (KETTENMANN et al., 2011). Gliomas present an increased expression of the $\mathrm{Kv} 10.1$ potassium channel. In addition, both glioma and microglia express the Kv 10.1 related gene product (ERG) (CAYABYAB; SCHLICHTER, 2002; PATT et al., 2004; ZHOU, 1998). Another voltage-gated potassium channel involved in microglial physiology is the Kv 1.3. Microglia expresses this channel in response to brain injury caused by radiation, and a specific $\mathrm{Kv} 1.3$ blocker could restrain microglia activation (PENG et al., 2014). The channel also allows microglia to be activated by proinflammatory stimulus like lipopolysaccharides (PANNASCH et al., 2006). In a recent work, D'Alessandro et al. (2013) found the potassium channel $\mathrm{KCa} 3.1$ contributing to both glioma invasiveness and activation of microglia. Therefore, the present work was aimed to investigate the role of $\mathrm{Kv} 10.1$ in the reciprocal influences between glioma cells and microglia.

\section{Methods}

\section{Ethics statement}

This work was conducted at the University of Saarland in strict accordance to the European and German guidelines for the welfare of experimental animals under the 
license 65/2013, approved by the Saarland state's "Landesamt fuer Gesundheit und Verbraucherschutz" in Saarbrücken/Germany.

\section{Cell culture}

This study used the mCherry-GL261 tumor cells (VINNAKOTA et al., 2013), a glioma cell line with expression of the fluorescent protein mCherry, kindly provided by Helmut Kettenmann (Max-Delbrück-Center for Molecular Medicine, Berlin, Germany) and microglia cell line BV-2, purchased from BCRJ (Rio de Janeiro, Brazil). Cells were maintained on $75 \mathrm{~cm}^{3}$ culture flasks with DMEM/F12 [supplemented with $10 \%$ (volume/volume) heat-inactivated fetal calf serum, and $1 \%$ of penicillin/streptomycin solution, all obtained from Invitrogen (Karlsruhe, Germany)]. When the confluence reached about $90 \%$, the cells were harvested using $0.25 \%$ Trypsin solution (Invitrogen, Karlsruhe, Germany).

\section{Mouse lines}

Adult C57BL/6N and TgH(CX3CR1-EGFP) heterozygous mice (JUNG et al., 2000) backcrossed to $\mathrm{C} 57 \mathrm{BL} / 6 \mathrm{~N}$ background for more than 10 generations were maintained at a temperature and light controlled animal facility, and received food and water ad libitum.

\section{Immunohistochemistry for Kv 10.1 and nucleus staining. After tumor} implantation, as cited by Resende, et al (2016), three animals were deeply anesthetized by injection of a mixed solution of ketamine $(1.4 \%)$ and xylazine $(0.2 \%)(5.0 \mathrm{ml} / \mathrm{kg}$ body weight) and intracardially perfused with $4.0 \%$ paraformaldehyde (PFA) in $0.1 \mathrm{M}$ phosphate buffer $(\mathrm{pH}=7.4)$. After perfusion, the tissue was post-fixed in PFA for $24 \mathrm{~h}$ at $4.0^{\circ} \mathrm{C}$. Brains were washed in PBS and cut with a vibrotome VT1000S (Leica, Nussloch, Germany) to prepare free-floating brain slices of $40 \mu \mathrm{m}$. Slices were treated with a blocking solution (0.3\% Triton X-100 and $5.0 \%$ horse serum in PBS) for $1 \mathrm{~h}$ at room temperature (RT). They were incubated with primary monoclonal antibody mAb62 anti$\mathrm{Kv} 10.1$ (mouse, 1:500) overnight at $4.0^{\circ} \mathrm{C}$. Then, brain slices were washed 3 times in PBS and incubated with the fluorescent secondary antibody (1:2000) diluted in the secondary antibody solution (2.0\% horse serum in PBS) for $2 \mathrm{~h}$ at RT. AlexaFluor ${ }^{\circledR} 633-$ labeled anti-mouse IgG antibody, and AlexaFluor ${ }^{\circledR} 488$-labeled anti-mouse IgG antibody (Molecular Probes) was used as secondary antibodies. For nucleus staining, TO-PRO-3 were added before the last wash step. Then, confocal images were taken using a laser- 
scanning microscope LSM-710 (Zeiss, Oberkochen, Germany) with appropriate excitation and emission filters. Z-stack images were taken at 0.8-2.0 $\mu \mathrm{m}$ intervals and processed with the ZEN software (Zeiss, Oberkochen, Germany). All data were collect from three randomly selected pictures, from three different slices from at least three mice per group.

Preparation of Conditioned Medium of Glioma (CMG). Glioma cells were maintained with DMEM in $25 \mathrm{~cm}^{3}$ culture flasks at $37{ }^{\circ} \mathrm{C}$ in a $5 \% \mathrm{CO}_{2}$ atmosphere for $24 \mathrm{~h}$. Conditioned mediums were centrifuged to remove debris and dead cells, filtered and immediately used in the experiments.

RNA isolation, synthesis of cDNA and RT-qPCR. Monolayer cell cultures were grown in six well plates with a density of $6 \times 10^{5}$ cells per well. Total RNA was extracted with the RNeasy Mini Kit following the manufacturer's instructions, and quantified by fluorometry. The cDNA synthesis was performed from $1000 \mathrm{ng}$ total RNA, by using oligo (dT). RT-qPCR reaction was carried out in QuantStudio $12 \mathrm{~K}_{\text {Flex }}{ }^{\mathrm{TM}}$ RealTime PCR System. The forward and reverse primers for $\mathrm{Kv} 10.1$ were 5'TTGGAGATGTGTTCTGGAAGGAA - 3' and 5' - AGGGCATCCCGCTTGATC - 3'. For the reference gene, we used the poly(A) polymerase alpha (PAPOLA) primers 5' GCTACGAAGACCAGTCCATTG - 3' and 5' - TGTTGGTCACAGATGCTGCT - 3'. Amplification products were detected via intercalation of the fluorescent dye Fast SYBR Green. $\Delta \Delta \mathrm{Ct}$ relative quantification method was used to express the $\mathrm{Kv} 10.1 \mathrm{mRNA}$ content.

Cell viability. Cell viability was determined by the MTT method. Briefly, 10000 cells were cultivated in 96-well plates. After each experimental condition, the cells were incubated with $15 \mu \mathrm{L}$ MTT (5 mg/mL in DMEM) for $4 \mathrm{~h}$ at $37{ }^{\circ} \mathrm{C}$. The medium was removed, and $150 \mu \mathrm{L}$ of DMSO was added to each well to dissolve formazan crystals. To quantity formazan product, we used a microplate reader calibrated to read the absorbance at $595 \mathrm{~nm}$. All experiments were performed in triplicate.

Immunocytochemistry. For detection of Kv 10.1, GL261mCherry and BV-2 microglia cells $\left(1 \times 10^{5}\right)$ were first cultured on coverslips in 24 -well plates. Then, they were fixed with $4 \%$ p-formaldehyde for 5 min, and permeabilized with $10 \%$ Triton X-100 in PBS for $10 \mathrm{~min}$. Then, were mounted and observed in a fluorescence microscope. Nonspecific binding was blocked with $5 \%$ serum Horse in PBS for $1 \mathrm{~h}$. We used the 
previously described Kv 10.1 monoclonal antibody anti-Eag1.62.mAb. This primary antibody $(1 \mu \mathrm{g} / \mathrm{mL})$ was diluted 1:1000 and incubated overnight at room temperature. AlexaFluor ${ }^{\circledR} 488$ labeled anti-mouse $\operatorname{IgG}$ antibody was used as a secondary antibody. Cell nucleus was labeled with Hoechst 33342 dye or TO-PRO-3. The coverslips were mounted and observed in a fluorescence microscope.

\section{Results and Discussion}

In the present study, the expression of $\mathrm{Kv} 10.1$ potassium channel in glioma cells was examined by using confocal microscopy with mAb62 antibody. We first investigated whether Kv 10.1 was expressed in glioma cells in culture. As shown in Fig. 1 D, Kv 10.1 channels (in green) were abundantly expressed by GL261-mCherry cells (in red). Confocal laser-scanning images suggests channel location in the plasma membrane, where they exert their physiological role in potassium ion flux. Negative controls are represented by assays without mAb62 primary antibody (Fig $1 \mathrm{E}$ )
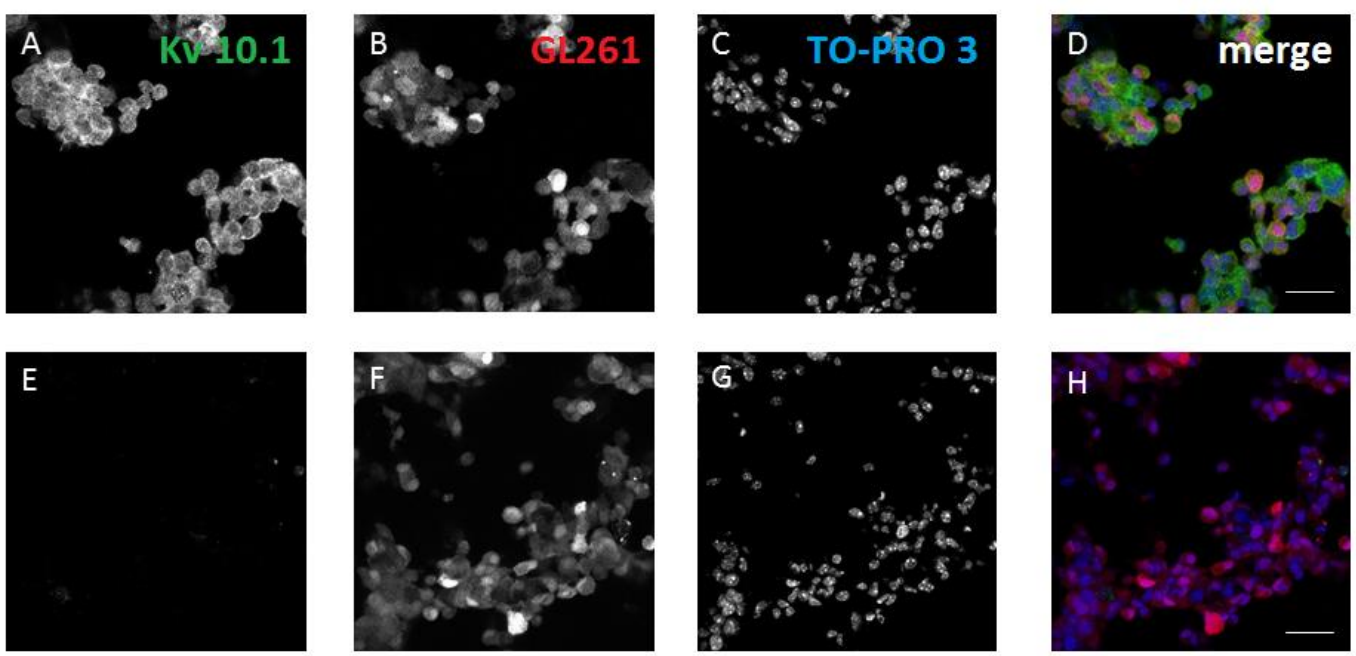

Figure 1. Expression of Kv 10.1 in glioma cells (GL261mCherry) in culture. Confocal microscopy with $\mathrm{Kv} 10.1 \mathrm{mAB}-62$ antibody in cultured. In first row, immunocytochemistry showing (A) Kv 10.1; (B) GL261; (C) To-Pro 3 staining cell nucleus; (D) merge image with Kv 10.1 (green), glioma cells (red), and cell nucleus (blue), $100 \mathrm{x}$ magnification. The following rows present (E) negative control without mAB-62 primary antibody; (F) GL261; (G) To-Pro 3 staining cell nucleus; (H) merge image with glioma cells (red), and cell nucleus (blue), $100 \mathrm{x}$ magnification. Scale bar $=100 \mu \mathrm{m}$.

In a second experiment, we investigated whether GL261-mCherry cells implanted in mouse brain would also express Kv 10.1. First, we injected glioma cells in the cortex of wild type mice. In Fig. 2D, we present glioma cells (red) and cell nucleus stained with 
To-Pro-3® (blue), and Kv 10.1 detection in green. The results reveal that injected glioma cells express $\mathrm{Kv} 10.1$.
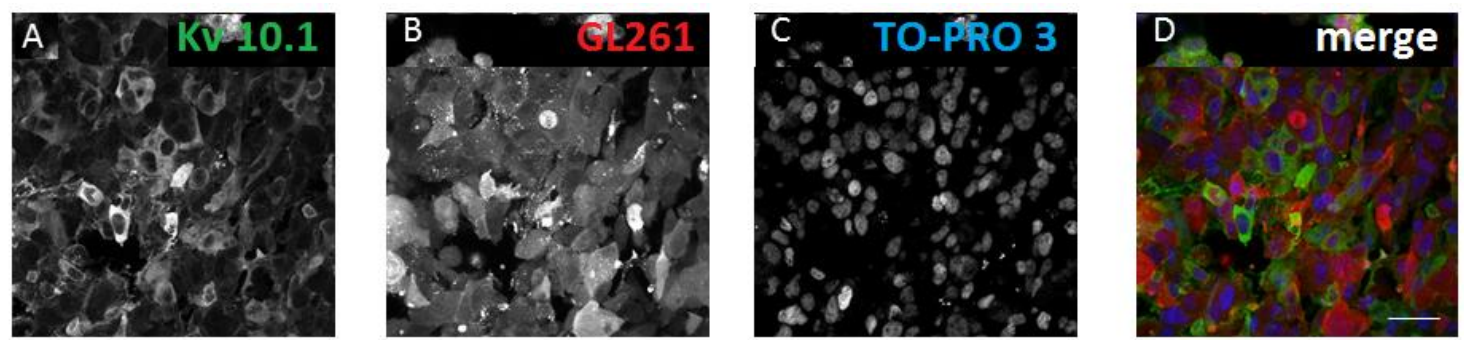

Figure 2. Expression of Kv 10.1 in C57BL/6N mice orthotopically injected with GL261mCherry glioma cells. 14 days post injection. Confocal microscopy images showing (A) Kv 10.1; (B) GL261; (C) To-Pro 3 staining cell nucleus; (D) merge image with Kv 10.1 (green), glioma cells (red), and cell nucleus (blue), 40 $\mathrm{x}$ magnification. Scale bar $=20 \mu \mathrm{m}$.

Then, we examined $\mathrm{Kv} 10.1$ expression in glioma cells in close contact with microglia. Glioma cells (red) growing in close contact with activated microglia (green) expressed $\mathrm{Kv} 10.1$ (blue), as shown in Figures $3 \mathrm{~A}$ to $\mathrm{G}$ (40 x magnification and $100 \mathrm{x}$ magnification, respectively). For comparison, we show a ramified microglia (green) found in the tumor-free contralateral hemisphere (Fig. 3 E) without Kv 10.1 detection. Immunohistochemical inspection detects $\mathrm{Kv} 10.1$ along contacts between microglial processes and surrounding glioma cells. Kv 10.1 immunosignal was also found in glioma cells growing with or without any contacting microglia (Fig. 3D).
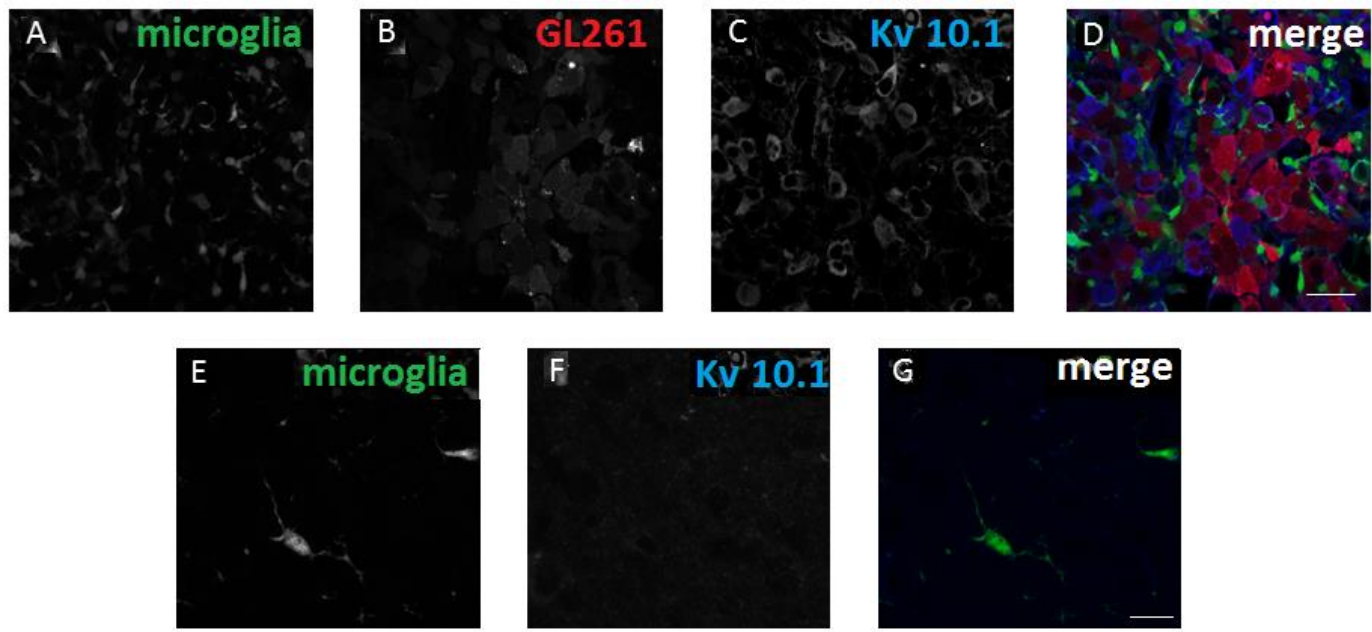

Figure 3. Expression of $\mathrm{Kv} 10.1$ in $\mathrm{TgH}(\mathrm{CX} 3 \mathrm{CR} 1-\mathrm{EGFP})$ mice orthotopically injected with GL261mCherry glioma cells. 14 days post injection. Confocal microscopy images showing (A) Microglia; (B) GL-261; (C) Kv 10.1; (D) merge image with microglia (green), glioma cells (red), and Kv 10.1 (blue), $100 \mathrm{x}$ magnification, scale bar $=20 \mu \mathrm{m}$. Kv 10.1 in contralateral brain hemisphere (E-G); (E) microglia; (F) $\mathrm{Kv} 10.1$; (G) merge image with Kv 10.1 (blue) and microglia (green), 100 x magnification. 
Immunohistochemical inspection detects $\mathrm{Kv} 10.1$ along contacts between microglial processes and surrounding glioma cells. Kv 10.1 immunosignal was also found in glioma cells growing with (Fig. 4, color arrows).

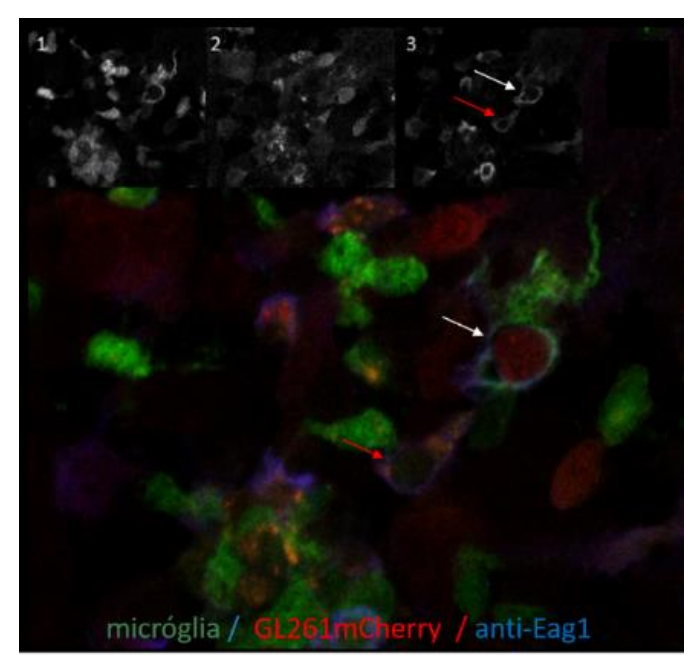

Figure 4. Expression of $\mathrm{Kv} 10.1$ in $\mathrm{TgH}(\mathrm{CX} 3 \mathrm{CR} 1-\mathrm{EGFP})$ mice orthotopically injected with GL261mCherry glioma cells. 14 days post injection. Maximum intensity projection of Kv 10.1 (blue) expression in glioma cells (red) surrounded by a microglial process (green). Color arrows indicate: a microglial process surrounding a glioma cell in parallel with $\mathrm{Kv} 10.1$ detection in glioma cells. Upper boxes (1-3) refers to microglia-EGFP (1), GL261 mCherry (2) and Kv 10.1 immunodetection. 40x. Scale bar $=20$ $\mu \mathrm{m}$.

In a second attempt, we examined the influence of glioma cells on microglia growth in vitro, exposing microglia cells to a CMG. Thus, CMG caused a significant increase in microglia viability, in comparison with the group that receive only a conventional medium, as determined by MTT test (Fig. 5).

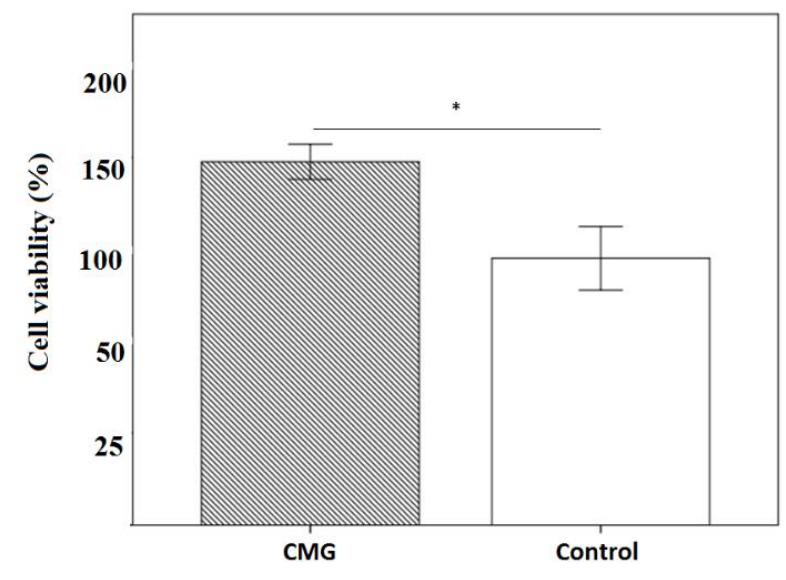

Figure 5. MTT assay indicating differences in viability rate between BV-2 cells that received the conditioned medium from glioma (CMG) and conventional medium, after 24-hour incubation. Results were expressed as mean \pm SEM. ${ }^{*} \mathrm{p}<0.05$. $(\mathrm{n}=4)$. 
Those data reinforces the notion that microglia are attracted by glioma cell during gliomagenesis (RESENDE et al., 2016). They migrate to tumor sites to present antigens, releasing cytokines and cytotoxins (ALOISI, 2001). However, the expected anti-tumor activity was found only in studies in vitro (SUTTER; HEKMAT; LUCKENBACH, 1991). Under glioma influence, microglia cells lack their natural role in immunological defenses, and acquire a pro-tumorigenic phenotype. Distinct classes of molecules released by glioma cells may promote the change to an alternative microglial phenotype, including the cytokine IL 10, tumor growth factor $\beta$, and the hormone prostaglandin E2 (DA FONSECA; BADIE, 2013; WEI; GABRUSIEWICZ; HEIMBERGER, 2013). Thus, we examined, in a cell culture model, whether a CMG will affect the Kv 10.1 expression in BV-2 microglia cell line. As shown in Fig. 6, CMG caused almost a 1.5-fold increase in expression of $\mathrm{Kv} 10.1$ in microglia cells.

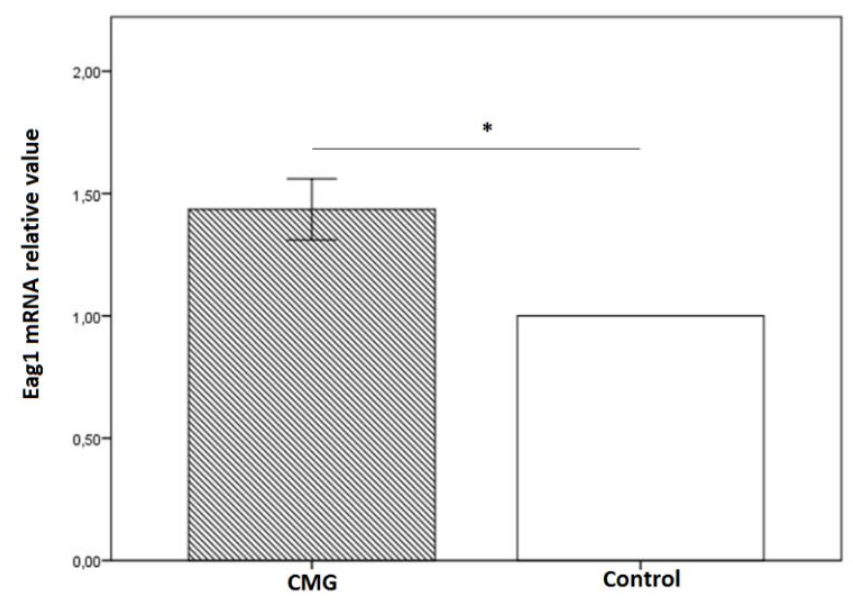

Figure 6. Real time qPCR showing the content of Kv 10.1 mRNA in BV-2 cells cultured with conditioned medium from glioma (CMG) per 24 hours. Data were normalized by the reference gene PAPOLA and compared by $2^{-\Delta \Delta C t}$ method $(n=4)$. Results were expressed as mean \pm SEM. ${ }^{*} p<0.05$.

Finally, Kv 10.1 expression in BV-2 cells was examined by immunocytochemistry (Fig. 7). Nuclei were stained with Hoechst 33342 (blue) and Kv 10.1 was detected by anti-Eag1.62.mAb labeled with green fluorescence. These immunofluorescence results confirmed the qPCR data and show that Kv 10.1 protein is highly expressed in cells that received the CMG. 

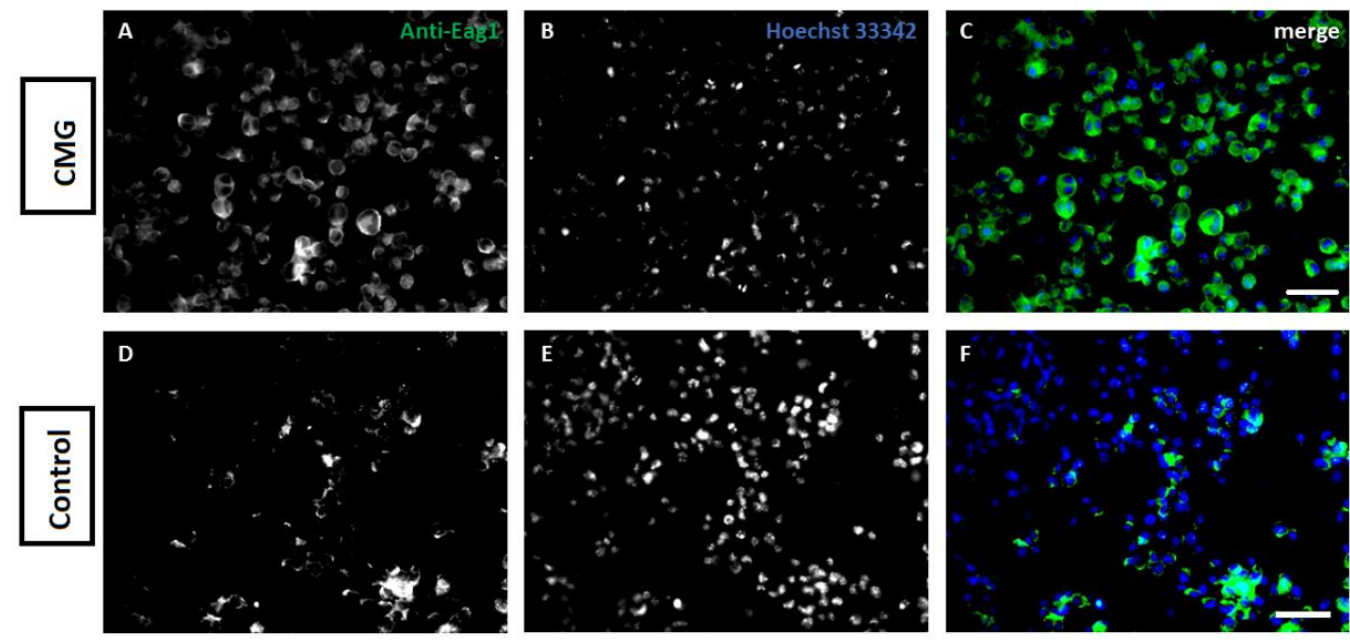

Figure 7. Kv 10.1 immunocytochemistry on BV-2 cell line. Representative images showing the increase in $\mathrm{Kv} 10.1$ expression in CMG group (A-C) in comparison with the controls (D-F). Images were acquired by fluorescence microscopy. Scale bar for all figures $=20 \mu \mathrm{m}$.

Voltage-gated potassium channels have gained increased attention in research about tumor biology and therapeutics (PARDO; STÜHMER, 2014). Kv 10.1 plays a role in tumorigenesis and is overexpressed in various types of tumors (HEMMERLEIN et al., 2006; PARDO et al., 1999). Both the low- and high-grade human gliomas express this potassium channel (PATT et al., 2004). Then, previous results, published by our group, confirms that the $\mathrm{Kv} 10.1$ inhibition affect the viability of glioma cells, confirming the need for Kv 10.1 in glioma cell growth. Also, cells silenced for Kv 10.1 exhibited a higher drop in cell viability when exposed to the apoptotic agent IFN-gamma (CUNHA et al., 2013). Regards to the glioma treatment, the standard protocol consists of the maximum surgical resection, radiotherapy, and chemotherapy with temozolomide (TMZ). Thus, TMZ leads to an increase in p53 protein, which accounts for its antitumor effects (HERMISSON et al., 2006). In addition, technologies that restore wild-type p53 function improves the effects of TMZ on glioma cells (KIM et al., 2014). Protein p53 negatively regulates Kv 10.1 (ESSMANN; SCHULZE-OSTHOFF, 2012; LIN et al., 2011). These facts suggest that TMZ, at least indirectly, might reduce $\mathrm{Kv} 10.1$ expression, favoring the drug effects on glioma cells.

The reciprocal influences between microglia and glioma that contributes to tumor expansion is a matter of capital importance in oncology. Besides chemical signaling, potassium channels also modulate the activation of microglial cells (KETTENMANN et al., 2011; RICHTER et al., 2014). Among them are Kv 10.1 related gene product (ERG), 
Kv1.3, and KCa3.1 (CAYABYAB; SCHLICHTER, 2002; D'ALESSANDRO et al., 2013; PATT et al., 2004; PENG et al., 2014; ZHOU, 1998)

\section{Conclusions}

In summary, we found that glioma cells in close contact with microglia present a high $\mathrm{Kv}$ 10.1 expression. As shown in Fig. $1 \mathrm{Y}, \mathrm{Kv} 10.1$ was detected at the contact between microglia and surrounded glioma cell. Microglia and glioma cells set up a close reciprocity during tumourigenesis. Previous works shown that microglia is recruited by glioma cells, changing its morphology to an amoeboid activated shape and promoting infiltration within tumor mass (RESENDE et al., 2016). In this way, the present study clarify some aspects of how glioma and microglial cells are involved in a reciprocal interaction in the tumor microenvironment. In light of our results, we can assert that glioma cells release soluble factors which increase Kv 10.1 expression in microglia cells, promoting vitality of these cells.

A further study may explore how the Kv 10.1 expression in microglia, induced by glioma cells, contributes to its growth and, if RNAi technology can regulate this effects. Therefore, we expected results that could underscore the potential of inhibiting $\mathrm{Kv} 10.1$ potassium channel as a therapeutic intervention against the growth of glioma.

\section{References}

ALOISI, F. Immune function of microglia. Glia, v. 36, n. 2, p. 165-79, nov. 2001.

CAYABYAB, F. S.; SCHLICHTER, L. C. Regulation of an ERG K+ current by Src tyrosine kinase. Journal of Biological Chemistry, v. 277, p. 13673-13681, 2002.

CUNHA LC, et al. RNA Interference with EAG1 Enhances Interferon Gamma Injury to Glioma Cells in Vitro. Anticancer Res. 33: 865-870, 2013.

D'ALESSANDRO, G. et al. KCa3.1 channels are involved in the infiltrative behavior of glioblastoma in vivo. Cell death \& disease, v. 4, p. e773, Jan. 2013.

DA FONSECA, A. C. C.; BADIE, B. Microglia and macrophages in malignant gliomas: recent discoveries and implications for promising therapies. Clinical \& developmental immunology, v. 2013, p. 264124, Jan. 2013. 
ESSMANN F AND SCHULZE-OSTHOFF K: Translational approaches targeting the p53 pathway for anticancer therapy. Br J Pharmacology. 165: 328-344, 2012.

HERMISSON M, et al: O6-methylguanine DNA methyltransferase and p53 status predict temozolomide sensitivity in human malignant glioma cells. J Neurochemical. 96: 766-76, 2006.

KETTENMANN, H. et al. Physiology of microglia. Physiological reviews, v. 91, n. 2, p. 461-553, abr. 2011.

KIM SS, et al: A nanoparticle carrying the p53 gene targets tumors including cancer stem cells, sensitizes glioblastoma to chemotherapy and improves survival. ACS Nano 8: 5494-514, 2014.

LIN H, et al: Transcriptional and post-transcriptional mechanisms for oncogenic overexpression of ether a go-go K+ channel. PLoS One. 6: e20362, 2011.

MCLENDON, R. E.; HALPERIN, E. C. Is the long-term survival of patients with intracranial glioblastoma multiforme overstated? Cancer, v. 98, n. 8, p. 1745-8, 15 out. 2003.

NAGASAWA, D. T. et al. Temozolomide and other potential agents for the treatment of glioblastoma multiforme. Neurosurgery clinics of North America, v. 23, n. 2, p. 307-22, ix, abr. 2012.

OSTROM, Q. T. et al. CBTRUS statistical report: Primary brain and central nervous system tumors diagnosed in the United States in 2006-2010. Neuro-oncology, v. 15 Suppl 2, p. ii1-56, nov. 2013.

PANNASCH, U. et al. The potassium channels Kv1.5 and Kv1.3 modulate distinct functions of microglia. Molecular and Cellular Neuroscience, v. 33, p. 401-411, 2006.

PATT, S. et al. Expression of ether à go-go potassium channels in human gliomas. Neuroscience Letters, v. 368, p. 249-253, 2004.

PENG, Y. et al. Blockade of Kv1.3 channels ameliorates radiation-induced brain injury. Neuro-Oncology, v. 16, p. 528-539, 2014.

RESENDE, F.F.B. et al. Evaluation of TgH(CX3CR1-EGFP) mice implanted with mCherry-GL261 cells as an in vivo model for morphometrical analysis of gliomamicroglia interaction. BMC cancer. No prelo, 2016. 
RICARD, D. et al. Primary brain tumours in adults. Lancet, v. 379, n. 9830, p. 1984-96, 26 maio 2012.

RICHTER, N. et al. Glioma-associated microglia and macrophages/monocytes display distinct electrophysiological properties and do not communicate via gap junctions. Neuroscience Letters, v. 583, p. 130-135, 2014.

STUPP, R. et al. Effects of radiotherapy with concomitant and adjuvant temozolomide versus radiotherapy alone on survival in glioblastoma in a randomised phase III study: 5year analysis of the EORTC-NCIC trial. The lancet oncology, v. 10, n. 5, p. 459-66, maio 2009.

SUTTER, A.; HEKMAT, A.; LUCKENBACH, G. A. Antibody-mediated tumor cytotoxicity of microglia. Pathobiology: journal of immunopathology, molecular and cellular biology, v. 59, n. 4, p. 254-8, Jan. 1991.

WATKINS, S.; SONTHEIMER, H. Unique biology of gliomas: challenges and opportunities. Trends in neurosciences, v. 35, n. 9, p. 546-56, set. 2012.

WEI, J.; GABRUSIEWICZ, K.; HEIMBERGER, A. The controversial role of microglia in malignant gliomas. Clinical \& developmental immunology, v. 2013, p. 285246, Jan. 2013.

ZHAI, H.; HEPPNER, F. L.; TSIRKA, S. E. Microglia/macrophages promote glioma progression. Glia, v. 59, n. 3, p. 472-85, mar. 2011.

ZHOU, W. HERG-like K+ Channels in Microglia. The Journal of General Physiology, 1998. 


\section{Capítulo 3 - Sobre o papel do canal de potássio Kv 10.1 na morte celular causada pela temozolomida}

\section{Título do artigo: Suppression of the Eag1 $\mathrm{K}^{+}$channel sensitizes glioblastoma cells to the injury caused by temozolomide}

Thais Torquato Sales*1, Fernando Francisco Borges Resende ${ }^{* 1}$, Natália Lemos Chaves $^{2}$, Sônia Nair Báo ${ }^{2}$, Marcella Lemos Brettas ${ }^{2,3}$ and Ricardo Titze-de-Almeida ${ }^{1}$

${ }^{1}$ Technology for Gene Therapy Laboratory, University of Brasilia (UnB), Brasília, Brazil.

${ }^{2}$ Department of Cellular Biology, Institute of Biological Sciences, University of Brasilia (UnB), Brasília, Brazil.

${ }^{3}$ Campus Planaltina, University of Brasília (UnB), Brasília, Brasil.

* Both authors contributed equally to this work

Aceito para publicação no Períodico Oncology Letters - Fator de impacto 1.55, qualis B1 - Medicina Veterinária. 


\begin{abstract}
Glioblastoma multiforme (GBM) is the most aggressive primary human brain tumor. The standard therapy protocol includes radiotherapy in combination with temozolomide (TMZ). Despite some advances in GBM treatment, the survival time of patients diagnosed with glioma is 14.5 months. About tumor biology, cancer cells overexpress the ether à go-go 1 (Eag1) potassium channel. The present study examined the role of Eag1 in the cell damage caused by TMZ on U87MG glioma cell line. For that, Eag1 was inhibited by using a channel blocker (astemizole) or a short-hairpin RNA expression vector (pKv10.13) that silences Eag1. pKv10.1-3 (0.2 $\mu \mathrm{g})$ improved the Eag1 silencing caused by TMZ $250 \mu \mathrm{M}$, as determined by RT-qPCR and immunocytochemistry. Inhibiting Eag1 with the vector or astemizole $(5 \mu \mathrm{M})$ reduced glioma cell viability, and sensitized cells to TMZ. Cell viability decreased by $63 \%$ for pKv10.1-3 + TMZ vs. $34 \%$ for TMZ alone and by $77 \%$ for astemizole + TMZ vs. $46 \%$ for TMZ alone, as determined by MTT assay. In addition, both the vector and astemizole increased the apoptosis of glioma cells triggered by TMZ. Taking collectively, our data reveal Eag1 plays a relevant role in the cell damage of glioma cells caused by TMZ. Moreover, suppression of this channel can improve the action of TMZ on U87MG glioblastoma cells. Silencing Eag1 is a promising strategy to improve GBM treatment, and merits further studies in animal models of glioma.
\end{abstract}

\title{
Introduction
}

Glioblastoma multiforme (GBM) is an astrocytoma of malignancy grade 4, i.e., a glioma with the highest degree of histological abnormality $(1,2)$. This malignant glioma grows rapidly due to the loss of signals that inhibit cell cycle and the increased signaling mediated by growth factors $(3,4)$. The standard treatment consists of the maximum surgical resection, radiotherapy, and chemotherapy with temozolomide (TMZ), the firstline therapeutic agent for $\operatorname{GBM}(3,5)$. The drug is a lipophilic substance with a low molecular weight (194.15), thus it is well absorbed by the oral route and crosses the blood-brain barrier to reach the target site (6). This alkylating agent generates cytotoxic DNA lesions in tumor cells, which results in cell cycle arrest and apoptosis. Chemotherapy with TMZ has shown clinical benefits in increasing the mean survival time and improving the patients' quality of life (7). However, the extended survival time reaches only 2.5 months in comparison with radiation therapy alone. Indeed, about $70 \%$ 
of patients with GBM present no benefit after TMZ treatment, which implies there is an urgent need for new anticancer approaches (8).

Voltage-gated potassium channels have gained increased attention in research about tumor biology and therapeutics (9). Our work focused on the ether à go-go 1 (Eag1), a channel that plays a role in tumorigenesis and is overexpressed in various types of tumors $(10,11)$. Both the low-grade and high-grade human gliomas express Eag1 (12). No previous work evaluated whether TMZ would affect Eag1 expression in glioblastoma cells. However, TMZ leads to an increase in p53 protein, which accounts for its antitumor effects (13). In addition, technologies that restore wild-type p53 function improves the effects of TMZ on glioma cells (14). Protein p53 negatively regulates Eag1 $(15,16)$. These results allowed us to hypothesize that $\mathrm{TMZ}$, at least indirectly, might reduce Eag1 expression, favoring the drug effects on glioma cells.

Eag1 is a definitive oncological target. Studies with different approaches reveal that decreasing Eag1 activity can undermine tumor progression (17). First, the Eag1 blockers imipramine and astemizole could reduce tumor cell growth (18-20). Monoclonal antibodies to Eag1 had also ability to control tumor development. They were as effective as the standard agent cyclophosphamide in a mouse model of breast cancer (21). Finally, RNA interference (RNAi) - the "state of art" tool for gene therapy. RNAi-based drugs for cancer therapy are already in clinical testing and will become approved treatments in the coming years (22). Small-interfering RNAs (siRNAs) designed to silence Eag1 could reduce the growth of different cancer cells in culture (23). Our group developed a plasmid vector able to express short-hairpin RNAs that targets the Eag1 mRNA, named pKv10.13. This expression vector also reduced the viability of glioma cells. In addition, pKv10.13 increased the cell damage caused by interferon gamma, a therapeutic agent for brain tumors $(24,25)$.

In this study, we first examined the effect of TMZ on Eag1 expression in U87MG glioma cells. We also evaluated whether silencing Eag1 with a short hairpin RNA would increase the cell damage caused by TMZ, the first-line therapeutic agent for GBM. 


\section{Methods}

Cell culture. Human glioblastoma U87MG lineage was purchased from the Bank of Cells of Rio de Janeiro (BCRJ; Rio de Janeiro, Brazil). Cells were maintained with DMEM/F12 [supplemented with 10\% (volume/volume) heat-inactivated fetal calf serum, $1 \%$ Glutamax and $1 \%$ of penicillin/streptomycin solution, all obtained from Invitrogen (California, USA)] in $25 \mathrm{~cm}^{3}$ culture flasks at $37{ }^{\circ} \mathrm{C}$ in a $5 \% \mathrm{CO} 2$ atmosphere.

Drug treatment. Temozolomide (Orion Corporation, Turku, Finland) and astemizole (Sigma-Aldrich, Madrid, Spain) were dissolved in Dimethyl Sulfoxide (DMSO, SigmaAldrich, Madrid, Spain) and stored at $-20^{\circ} \mathrm{C}$. The final concentration of DMSO in culture medium did not exceed $0.01 \%$, causing no influence in cell viability, according to preliminary experiments (data not shown). Details of each experimental procedure are presented in the figure legends and schematic representations.

Cell viability measurement by MTT assay. Cell viability was determined by 3(4,5-dimethylthiazol-2yl)2,5-diphenyl-2H-tetrazolium bromide (MTT) method. Briefly, 10.000 cells were cultivated in 96-well plates. After each experimental treatment, the cells were incubated with $15 \mu \mathrm{L}$ MTT $\left(5 \mathrm{mg} / \mathrm{mL}\right.$ in DMEM) for $4 \mathrm{~h}$ at $37{ }^{\circ} \mathrm{C}$. Then, the medium was removed, and $150 \mu \mathrm{L}$ of DMSO was added to each well to dissolve formazan crystals. To quantity formazan product, we used a microplate reader (SpectraMax ${ }^{\circledR}$ M2 Microplate Reader, Molecular Devices, California, USA) calibrated to read the absorbance at $595 \mathrm{~nm}$. All experiments were performed in triplicate. The number of independent assays is presented in the figure legends.

Cell transfection method. This study used a previously described shRNA expression vector targeting Eag1 mRNA sequence 5'GTCCACTTGGTCCATGTCCAG-3', named pKv10.1-3 (24). Lipofectamine 2000 and Opti-MEM (Invitrogen, California, USA) were used to transfect pKv10.1-3 and the negative control pScramble, according to the manufacturer's instructions. Both vectors were built in pSilencer® 3.1-H1 platform (Applied Biosystems, California, USA).

RNA isolation, synthesis cDNA and RT-qPCR. Monolayer cell cultures were grown in six well plates with a density of 6x105 cells per well. Total RNA was extracted with the RNeasy® Mini Kit (Qiagen, Hilden, Germany) following the manufacturer's instructions, and quantified by fluorometry (Qubit, Invitrogen, California, USA). The 
purity was considered acceptable for RNA/protein ratios above 1.8. RNA integrity was analyzed by agarose gel electrophoresis. The cDNA synthesis was performed from 2.500 ng total RNA, by using oligo (dT) (SuperScript First-Strand Synthesis System for RTPCR, Invitrogen, California, USA). Real time PCR reaction was carried out in QuantStudio 12K Flex ${ }^{\mathrm{TM}}$ Real-Time PCR System (Applied Biosystems, California, USA). The forward and reverse primers for Eag1 were 5' TTGGAGATGTGTTCTGGAAGGAA - 3' and 5' - AGGGCATCCCGCTTGATC - 3' (26). For the reference gene, we used the poly(A) polymerase alpha (PAPOLA) primers 5' - GCTACGAAGACCAGTCCATTG - 3' and 5' - TGTTGGTCACAGATGCTGCT $3^{\prime}(24,27)$. This gene was selected from a previous study that evaluated the stability of many endogenous reference genes in tumor cells. We tested four genes that presented a high gene expression stability score in that study: TBP, GPB, CUL1 and PAPOLA. Among them, PAPOLA showed the lowest rate of variation of $\mathrm{Ct}$ values (qPCR) in glioma cells silenced from Eag1 compared with controls (about 2\%), an experimental condition that also reduces cell viability. Amplification products were detected via intercalation of the fluorescent dye Fast SYBR Green (Applied Biosystems, California, USA). Briefly, $10 \mu \mathrm{L}$ reaction mix contained 5.0 $\mu \mathrm{L}$ Fast SYBR Green Master mix, 2.0 $\mu \mathrm{L}$ of cDNA, and $0.4 \mu \mathrm{L}$ each sense and antisense primer $(10 \mathrm{pmol} / \mu \mathrm{L})$. The PCR program included an initial denaturation at $95^{\circ} \mathrm{C}$ for $5 \mathrm{~min}$, followed by 40 cycles of amplification $\left(95^{\circ} \mathrm{C}\right.$ for $1 \mathrm{~min}, 60^{\circ} \mathrm{C}$ for $1 \mathrm{~min}$ ). Each sample was carried out in triplicate, and the assay included a non-template negative RT controls. Relative quantification method $(\Delta \Delta \mathrm{Cq})$ was used to express the RNAi effects on Eag1 mRNA content.

Apoptosis assay - flow cytometry. For apoptosis analysis, we used the commercialized Alexa Fluor ${ }^{\circledR} 488$ Annexin V / Dead Cell Apoptosis Kit (Invitrogen, California, USA). Samples were prepared according to the manufacturer's protocol with short modifications. In brief, 1x105 cells were plated in 12-well plates. After treated, they were washed with PBS and resuspended in a solution containing $100 \mu \mathrm{L}$ of binding buffer, $5 \mu \mathrm{L}$ of Annexin V-FITC and $10 \mu \mathrm{L}$ of propidium iodide. In this step, cells were incubated for 10 minutes in the dark at room temperature. Next, $400 \mu \mathrm{L}$ of binding buffer were added to the cells and 10,000 events for each sample were acquired by flow cytometry (FACSVerse ${ }^{\mathrm{TM}}$, BD Biosciences, New Jersey, USA). After the acquisition, we executed the analysis by using the software FlowJo (Tree Star Inc., Ashland, USA). 
Immunocytochemistry and image analysis. For immunocytochemical detection of Eag1, U87MG cells (1x105) were first cultured on coverslips in 24-well plates. Then, they were fixed with $4 \%$ p-formaldehyde for $15 \mathrm{~min}$, and permeabilized with $10 \%$ Triton $\mathrm{X}-100$ in PBS for 10 min. Nonspecific binding was blocked with 5\% serum Horse in PBS for $1 \mathrm{~h}$. We used the previously described Eag1 monoclonal antibody anti-Eag1.62.mAb (21). This primary antibody $(1 \mu \mathrm{g} / \mathrm{mL})$ was diluted 1:500 and incubated overnight at 4 ${ }^{\circ}$ C. Alexa Fluor ${ }^{\circledR} 488$ labeled anti-mouse IgG antibody (1:2000, Molecular Probes, Oregon, USA) was used as a secondary antibody. The cell's nucleus was labeled with Hoechst 33342 dye (Sigma-Aldrich, Madrid, Spain). To evaluate the morphology of cytoskeleton, we used a commercial kit for Phalloidin detection (Alexa Fluor ${ }^{\circledR} 532$ Phalloidin, 200 units/mL, Molecular Probes, Oregon, USA), following the manufacturer's protocol. The coverslips were mounted and observed with a confocal microscope (Leica TCS SP5, Wetzlar, Germany).

To measure the corrected total cell fluorescence (CTCF) for Eag1, we used the formula CTCF = Integrated Density - (Area of selected cell X Mean fluorescence of background readings). Cell morphology was visualized using a binary (mask-like) image of Phalloidin detection, and cell's nucleus was labeled with Hoechst 33342 dye (Sigma-Aldrich, Madrid, Spain). Image analysis was executed by using ImageJ software. Each experimental condition was performed in triplicate, in three independent experiments.

Statistical analysis. All data were analyzed by using the Statistical Package for Social Sciences (SPSS) version 20.0 and expressed as mean \pm standard error of the mean. We used the one-way analysis of variance (ANOVA) followed by Tukey's test, to test the differences between groups. Differences between pairs of experimental groups were analyzed by the Student - $t$ test. The level of statistical significance adopted was $\mathrm{p}<0.05$.

\section{Results}

TMZ affects the viability of U87MG glioma cells. We first carried out a doseresponse curve to examine the cell damage of TMZ on glioblastoma cells, by using the MTT assay. The mock control group, without any treatment, was taken as $100 \%$ viability. TMZ caused a decrease in cell viability in all periods of time examined, 24, 48 and $72 \mathrm{~h}$. As shown in Fig. 1A, the intensity of cell damage varied according to each TMZ concentration and the time points examined. At $125 \mu \mathrm{M}$, TMZ caused a slight but stable 
decrease in cell viability to $91 \%, 87 \%$ and $89 \%$ during the time points 24,48 and $72 \mathrm{~h}$, respectively (Fig. 1A). However, cells exposed to TMZ $250 \mu \mathrm{M}$ presented a timedependent change in their viability, from $84 \%$ at $24 \mathrm{~h}$ to $54 \%$ at $72 \mathrm{~h}$ (Fig. $1 \mathrm{~A} ; \mathrm{p}<0.05$ ). At the highest concentration evaluated, $500 \mu \mathrm{M}$, TMZ also caused a time-dependent effect. The viability of glioma cells varied from $59 \%$ to $13 \%$ between the time points 24 $h$ and $72 \mathrm{~h}$ (Fig. 1A; p<0.05).

In summary, at $72 \mathrm{~h}$ glioma cells presented a more linear response to the increasing doses of TMZ (Fig.1A). At this time point, the $250 \mu \mathrm{M}$ drug concentration decreased cell viability to a value close to $50 \%$. We chose this condition for the following tests on the role of Eag1 in the effects of TMZ.

\section{Effects of TMZ and pKv10.1-3 on glioma cell viability and Eag1}

expression. We first determined the content of Eag1 mRNA in temozolomide-injured glioma cells, by RT-qPCR. Temozolomide $(250 \mu \mathrm{M})$ caused a 0.78 fold decrease in Eag1 mRNA at $72 \mathrm{~h}$ after injury (Fig. 1B). Indeed, the shRNA expression vector, pKv10.1-3 $(0.2 \mu \mathrm{g})$, was capable to knock down Eag1 mRNA. Transfected cells presented a 0.57 fold decrease in Eag1 content compared to the pScramble $(0.2 \mu \mathrm{g})$ negative control group, as expressed by the $2-\Delta \Delta \mathrm{Cq}$ (Fig. $1 \mathrm{C} ; \mathrm{p}<0.05$ ). Finally, we examined the effect of temozolomide on Eag1 in cells pre-transfected with pKv10.1-3. The vector significantly improved the down regulation of Eag 1 caused by temozolomide on glioma cells at $72 \mathrm{~h}$. Eag1 mRNA content was reduced from 0.78 fold, for temozolomide $250 \mu \mathrm{M}$ alone, to 0.31 fold for temozolomide plus pKv10.1-3 (Fig. 1D; p<0.05).

Eag1 expression in U87MG cells was also examined by immunocytochemistry (Fig. 1EH). Nuclei were counterstained with Hoechst 33342 (blue) and Eag1 detected by antiEag1.62.mAb labeled with green fluorescence, and then examined by confocal microscopy. Merged squares show the combined images of both Hoechst staining and Eag1 immunodetection (Fig. 1E-H). We found that Eag1 is highly expressed in human glioblastoma multiforme U87MG cells (Fig. 1E, CTCF=19.65 \pm 0.76 ). Indeed, TMZ and the vector pKv10.1-3 significantly decreased this expression of Eag1 (Fig. 1F-H). Treatments with pKv10.1-3, TMZ 250 $\mu \mathrm{M}$ or pKv10.1-3 in association with TMZ 250 $\mu \mathrm{M}$ reduced the CTCF values to $6.97 \pm 0.79,5.37 \pm 0.37$ and $3.86 \pm 0.49$, respectively (Fig. 1I). 


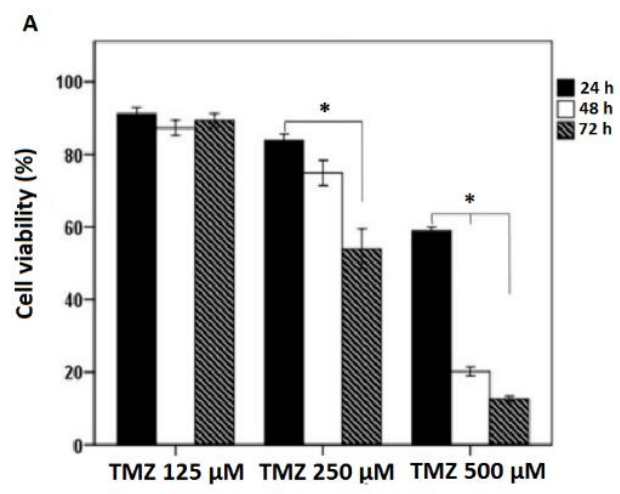

C

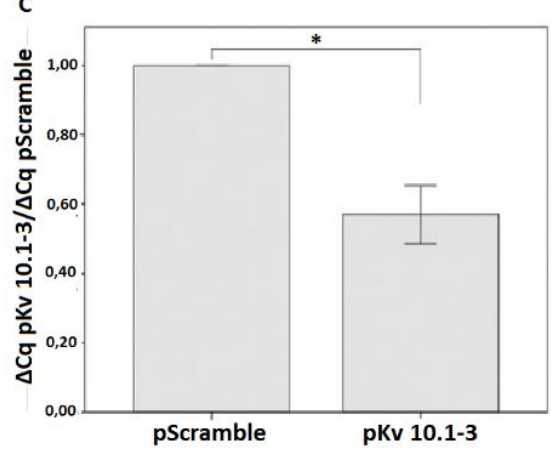

B

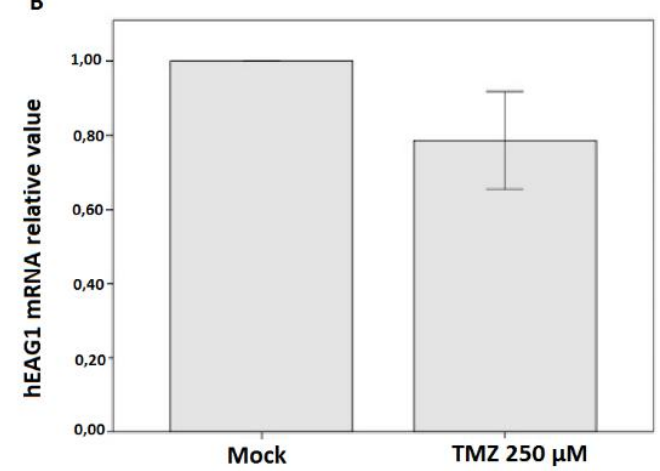

D

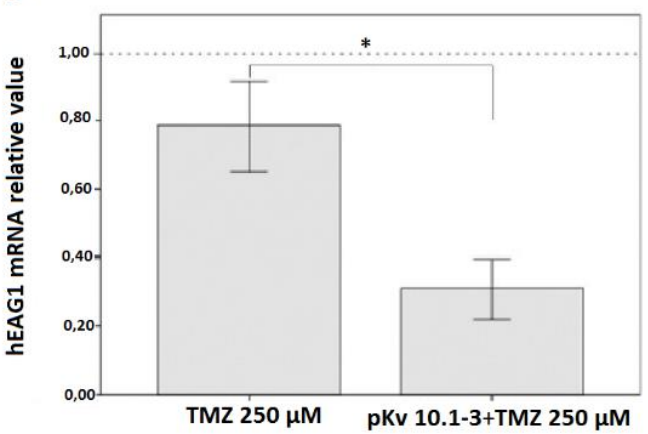

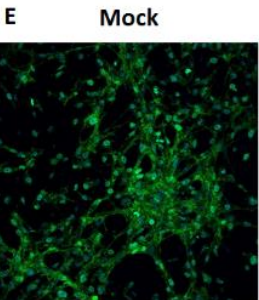

F $\quad$ pKv 10.1-3
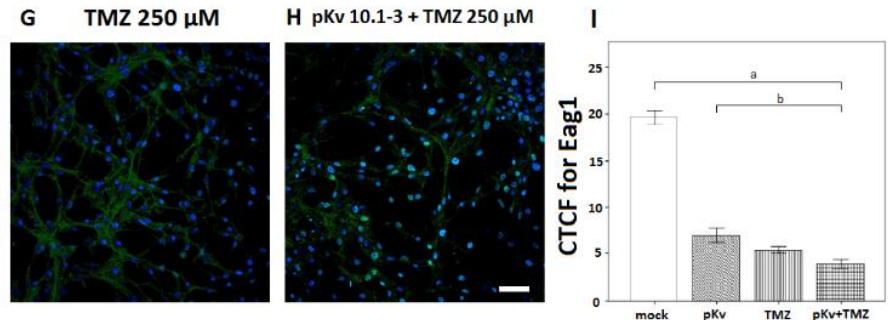

Figure 1. TMZ and pKv10.1-3 affect U87MG cell viability and Eag1 expression. Cell viability in each TMZ-treated group $(125,250$ or $500 \mu \mathrm{M})$ was expressed in comparison to the mock control values at 24 , 48 and 72 hours, as determined by MTT assay (A). All experimental groups were analyzed in triplicate in eight independent assays. The results were represented by a percentage of the value found in the mock control group and expressed by mean \pm SEM. $* p<0.05$. Eag1 mRNA content in glioma cells injured by TMZ $250 \mu \mathrm{M}$ per $72 \mathrm{~h}$, as revealed by qPCR (B). Effects of pKv10.1-3 (0.2 $\mu \mathrm{g})$ on Eag1 mRNA compared to a control vector pScramble (C). pKv10.1-3 increased the effect of TMZ 250 $\mu \mathrm{M}$ on Eag1 mRNA (D). Data were normalized by the reference gene poly(A) polymerase alpha (PAPOLA) and compared by 2$\Delta \Delta \mathrm{Cq}$ method $(\mathrm{n}=3)$. Eag1 immunocytochemistry in U87MG cells $(\mathrm{E}-\mathrm{H})$. Representative images showing the expression of Eag1 in Mock control group (E), and the respective decrease after treatments with pKv10.1-3 (F), TMZ 250 $\mu \mathrm{M}(\mathrm{G})$, or association of pKv10.1-3 and TMZ $250 \mu \mathrm{M}(\mathrm{H})$. Corrected total cell fluorescence (CTCF) for Eag1 (I). pKv10.1-3 was referred as pKv for simplicity. Eag1 intensity was decreased in all treated groups in relation to the mock $(a=p<0.05)$. Eag1 intensity was significantly lower in cell group treated with pKv10.1-3 in association with TMZ 250 $\mu \mathrm{M}$ in comparison with pKv10.1-3 alone $(b=p<0.05)$. Images were acquired by confocal microscopy. Scale bar $=20 \mu \mathrm{m}$.

\section{Astemizole and pKv10.1-3 reduce the viability of glioma cells. We}

examined the role of Eag1 in the viability of glioma cells by using astemizole, a channel blocker, and pKv10.1-3, a plasmid that silences this target. First, we found that astemizole caused a dose-dependent effect on the viability of glioma cells that remained for $72 \mathrm{~h}$, as determined by MTT assay (Fig. 2A-C). At $24 \mathrm{~h}$, cells treated with astemizole $2.5 \mu \mathrm{M}, 5$ 
$\mu \mathrm{M}$ or $10 \mu \mathrm{M}$ presented reduction in values of viability of $23 \%, 57 \%$ and $85 \%$, respectively (Fig. 2A). At the same concentrations, the drug also caused a dose-response effect at $48 \mathrm{~h}$, to values ranging from $42 \%$ to $93 \%$ in relation to the same treatments (Fig. 2B). Moreover, at $72 \mathrm{~h}$, astemizole also reduced the viability of glioma cells by $41 \%$, $72 \%$, and 93\%, according to the dose used, $2.5 \mu \mathrm{M}, 5 \mu \mathrm{M}$ and $10 \mu \mathrm{M}$ (Fig. 2C).

RNAi with Eag1 also affected glioma cells. Cells transfected with pKv10.1-3 (0.2 $\mu \mathrm{g})$ showed a stable decrease in their viability from $24 \mathrm{~h}$ to the last time point in study, $72 \mathrm{~h}$, as observed by MTT assay. Values of cell viability decreased to $47 \%, 35 \%$, and $40 \%$, at 24, 48 and $72 \mathrm{~h}$ after this transfection, respectively (Fig. 2D-F). Lipofectamine also caused a decrease in glioma cell viability that was more intense at $24 \mathrm{~h}(22 \%)$ than at 72 $\mathrm{h}(10 \%)$. Taking together, the results of astemizole and pKv10.1-3 confirmed a role for Eag1 in preserving glioma cell viability.

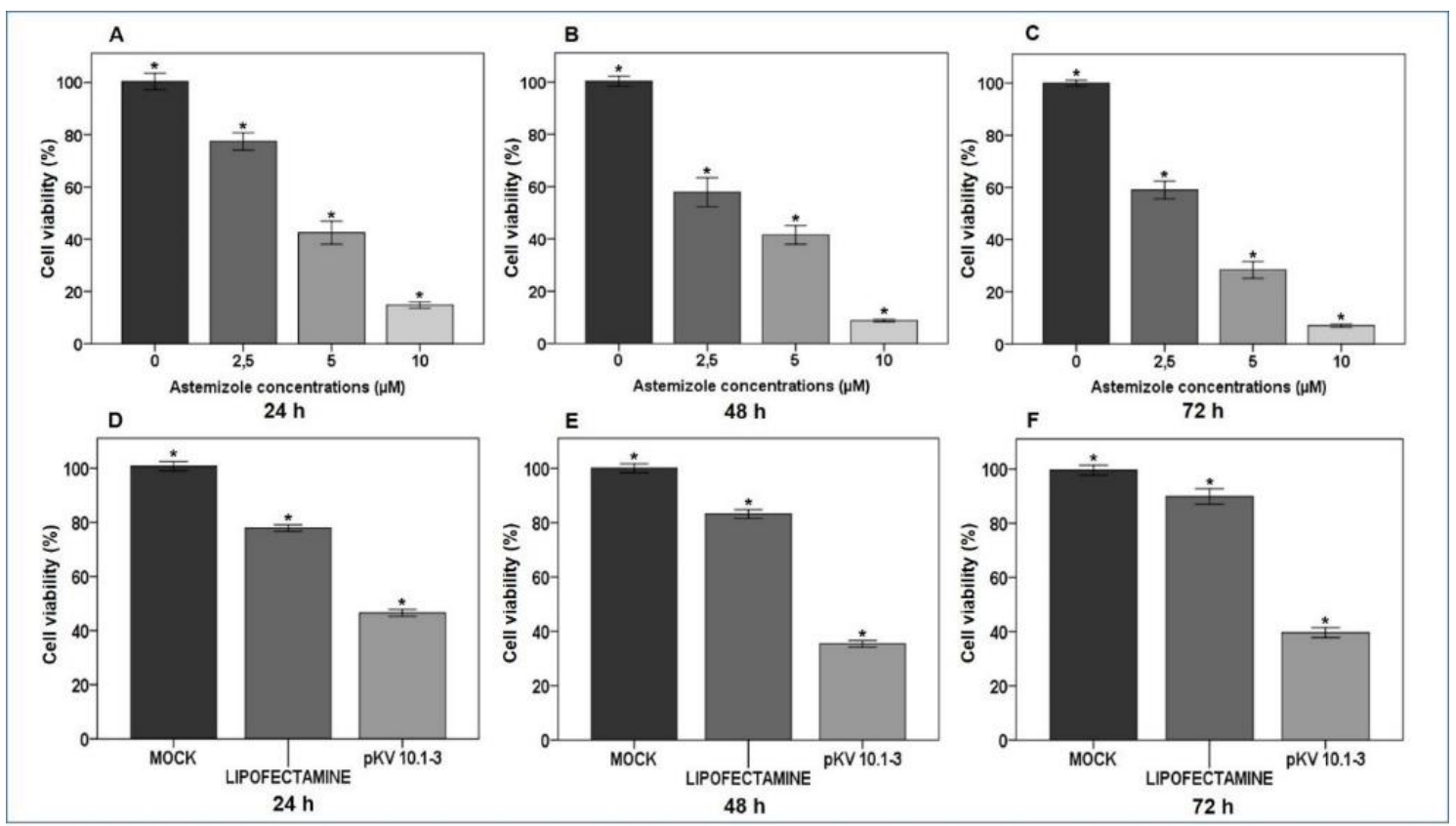

Figure 2. Effects of astemizole (ATZ) and pKv10.1-3 (0.2 $\mu \mathrm{g}$ ) on U87MG cell viability. Effects of different concentrations of ATZ $(2.5,5$ and $10 \mu \mathrm{M})$ at three time points of incubation (24, 48 and 72 hours) (A-C). Effects of pKv10.1-3 on cell viability at 24, 48 and 72 hours (D-F). Cell viability was determined by MTT assay. All experimental groups were analyzed in triplicate in eight independent assays. The results were represented by a percentage of the value found in the mock control group and expressed by mean \pm SEM. $* \mathrm{p}<0.05$.

\section{Suppression of Eag1 by astemizole or pKv10.1-3 sensitize cells to TMZ}

injury. This section explored the effects of Eag1 channel suppression in the injury caused by TMZ on glioma cells. Cell preparations received TMZ after Eag1 suppression, which varied according to each experimental method. Thirty minutes were enough for 
Eag1 blockade with astemizole, whereas six hours was the period of time needed for pKv10.1-3 transfection. Experimental groups pretreated with the Eag1 channel blocker astemizole or pKv10.1-3 showed a higher response to TMZ, as examined by MTT test. Cells received astemizole $(5 \mu \mathrm{M})$ for $30 \mathrm{~min}$, then TMZ $250 \mu \mathrm{M}$ for $72 \mathrm{~h}$ (Fig. 3A). Cell viability decreased by $77 \%$, a value significantly higher than those found in groups treated either with astemizole $(58 \%)$ or TMZ alone (46\%) (Fig. 3A; $<<0.05)$.

Indeed, glioma cells silenced from Eag1 with pKv10.1-3 (0.2 $\mu \mathrm{g})$ presented a higher drop in cell viability in response to TMZ (Fig. 3B). About TMZ $250 \mu \mathrm{M}$ plus pKv10.1-3, cell viability decreased by $77 \%$, a value significantly higher than those found in groups treated with pKv10.1-3 (54\%) or TMZ alone (48\%). Groups treated with TMZ $500 \mu \mathrm{M}$ plus pKv10.1-3 also presented a higher decrease in viability, compared with the group treated with only TMZ. Thus the vector was capable to enhance TMZ effects on glioma cells at two drug doses, $250 \mu \mathrm{M}$ and $500 \mu \mathrm{M}$, causing a dose-response effect.

A

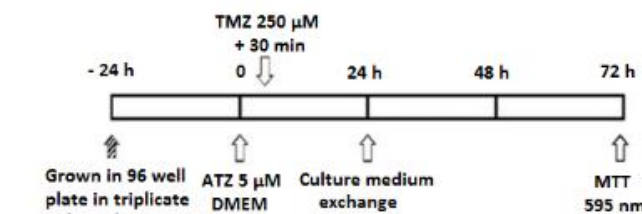
plate in triplicate DMEM exchange
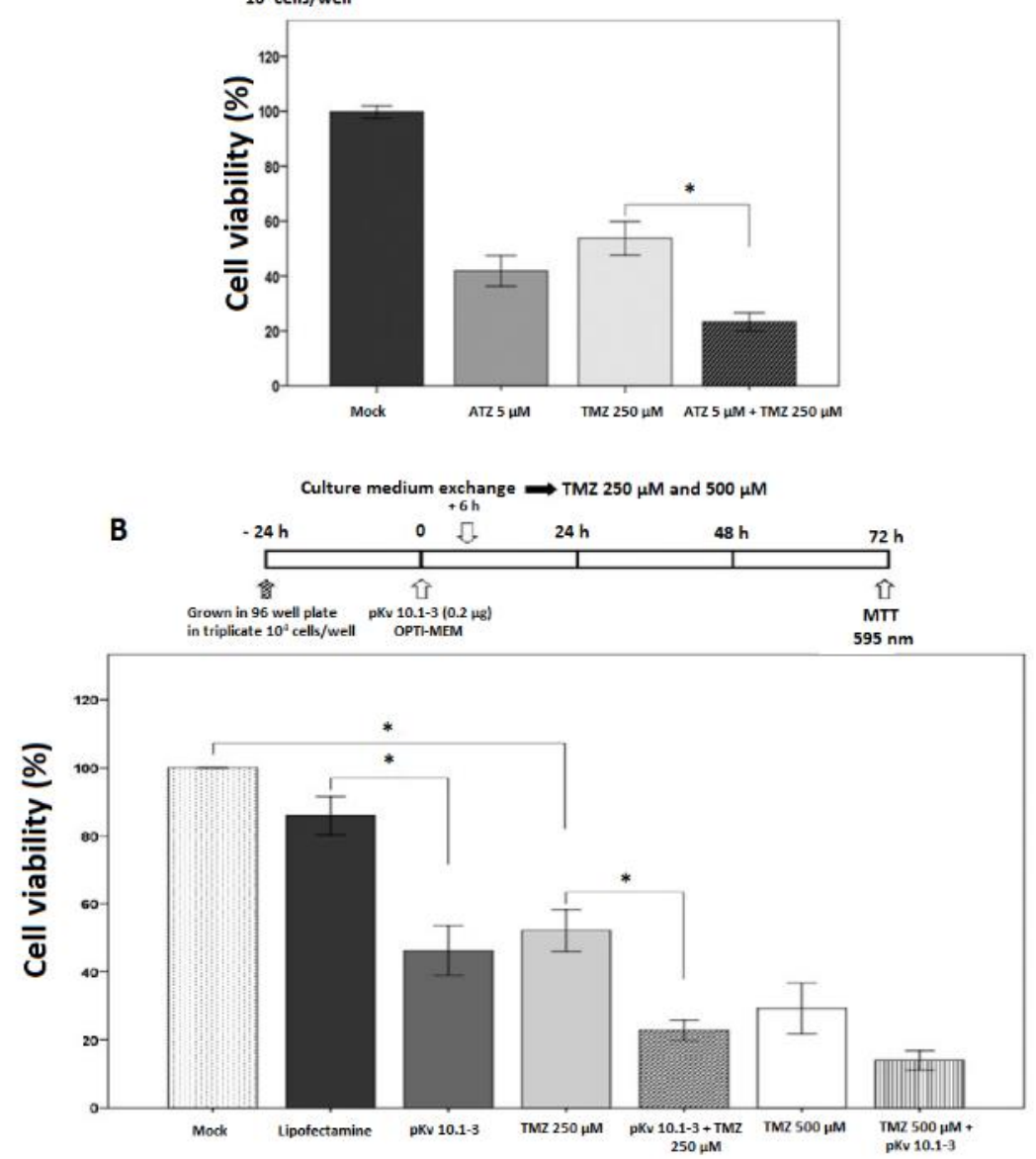
Figure 3. Effects caused by astemizole (ATZ) or pKv10.1-3, in association with temozolomide (TMZ), on U87MG cell viability. At the top of each figure, a schematic representation of the experimental procedure. Cell viability of glioma cells under pharmacological blockade of Eag1, in association with TMZ (A). Cell viability of glioma after pKv10.1-3 transfection, in combination with TMZ (B). Cell viability was determined by MTT assay. Experimental groups were analyzed in triplicate in eight independent assays. Data presented as mean \pm SEM. $* \mathrm{p}<0.05$.

Apoptosis of GBM cells determined by flow cytometry. We further examined whether Eag1 suppression would increase the rate of apoptosis in glioma cells injured by temozolomide. A flow cytometry analysis employing Annexin V-FITC / propidium iodide (PI) double staining assay was performed. As shown in Fig. 4A-G, early apoptosis (Annexin $\mathrm{V}+/ \mathrm{PI}-$ ) and later stage apoptosis (Annexin $\mathrm{V}+/ \mathrm{PI}+$ ) are represented in the quadrants Q4 and Q2, respectively. The mock control group corresponds to cells without treatment. Suppression of Eag1 increased the induction of apoptosis (Q4+Q2) caused by temozolomide (Fig. 4H). Blocking Eag1 with astemizole increased four times glioma cell apoptosis induced by temozolomide, i.e. from $17 \%$ to $82 \%$ (Fig. $4 \mathrm{~B}$ vs. $4 \mathrm{D}$, and $4 \mathrm{H}$; $\mathrm{p}<0.05$ ). In addition, silencing Eag1 with $\mathrm{pKv} 10.1-3$ tripled the rate of apoptosis triggered by TMZ (17\% vs. $63 \%$ ) (Fig. $4 \mathrm{~B}$ vs. $4 \mathrm{G}$, and $4 \mathrm{H} ; \mathrm{p}<0.05$ ).

Cell groups suppressed from Eag1 and damaged with TMZ also showed changes in cell morphology, as revealed by confocal microscopy (Fig. 4I-L). The cell filaments in pKv10.1-3 + TMZ $250 \mu \mathrm{M}$ treated group were relatively thinner compared to the controls (Fig. 4I-L, gray arrows). Mock group (Fig. 4I) and those that received pKv10.1-3 (Fig. $4 \mathrm{~J}$ ) or TMZ $250 \mu \mathrm{M}$ (Fig. 4K) alone showed a more stable morphology and survival rate, compared with the group treated with pKv10.1-3 + TMZ $250 \mu \mathrm{M}$ (Fig. 4L). These cells groups also presented a lower adherence and round floating shapes. 


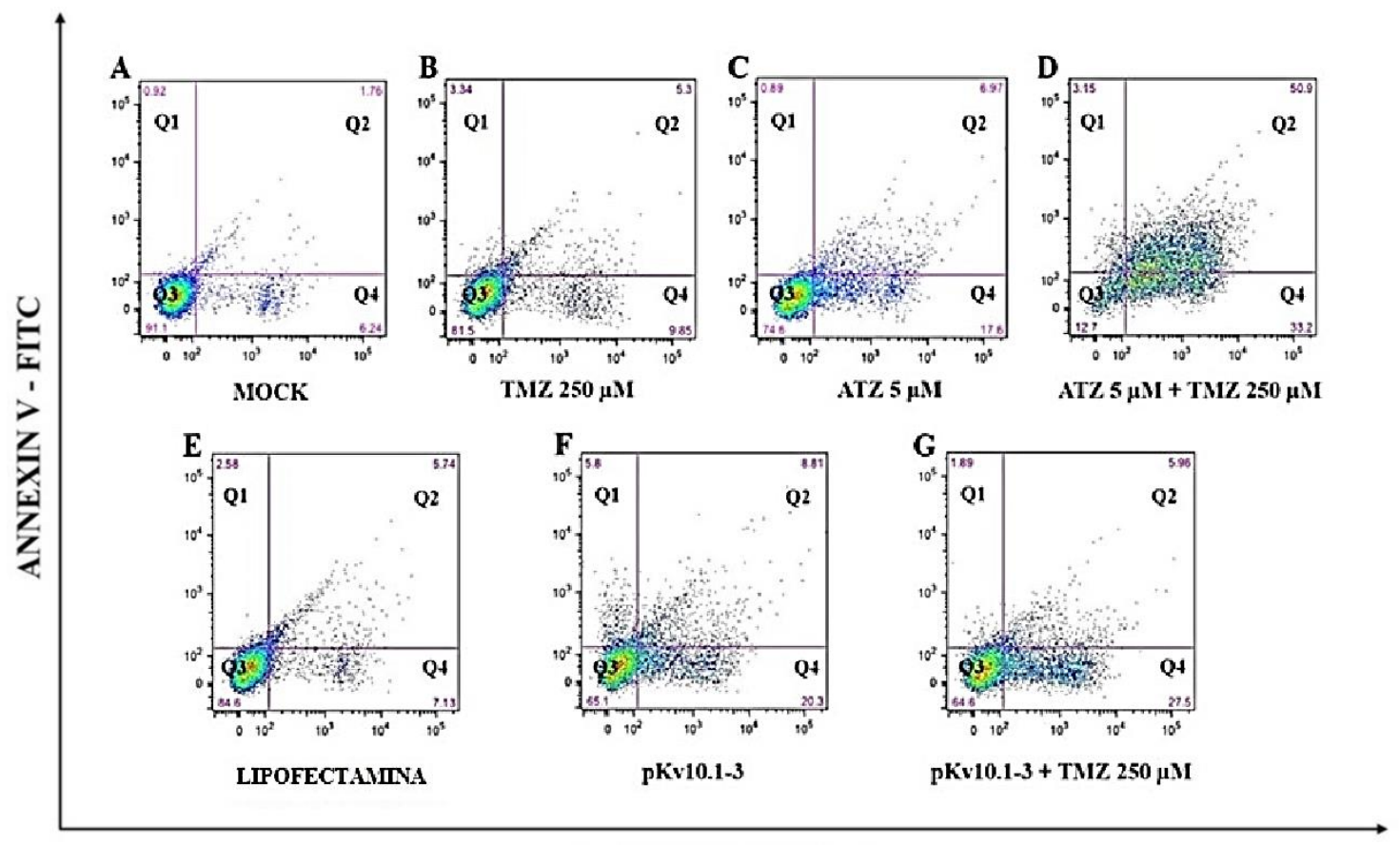

\section{PROPIDIUM IODIDE}
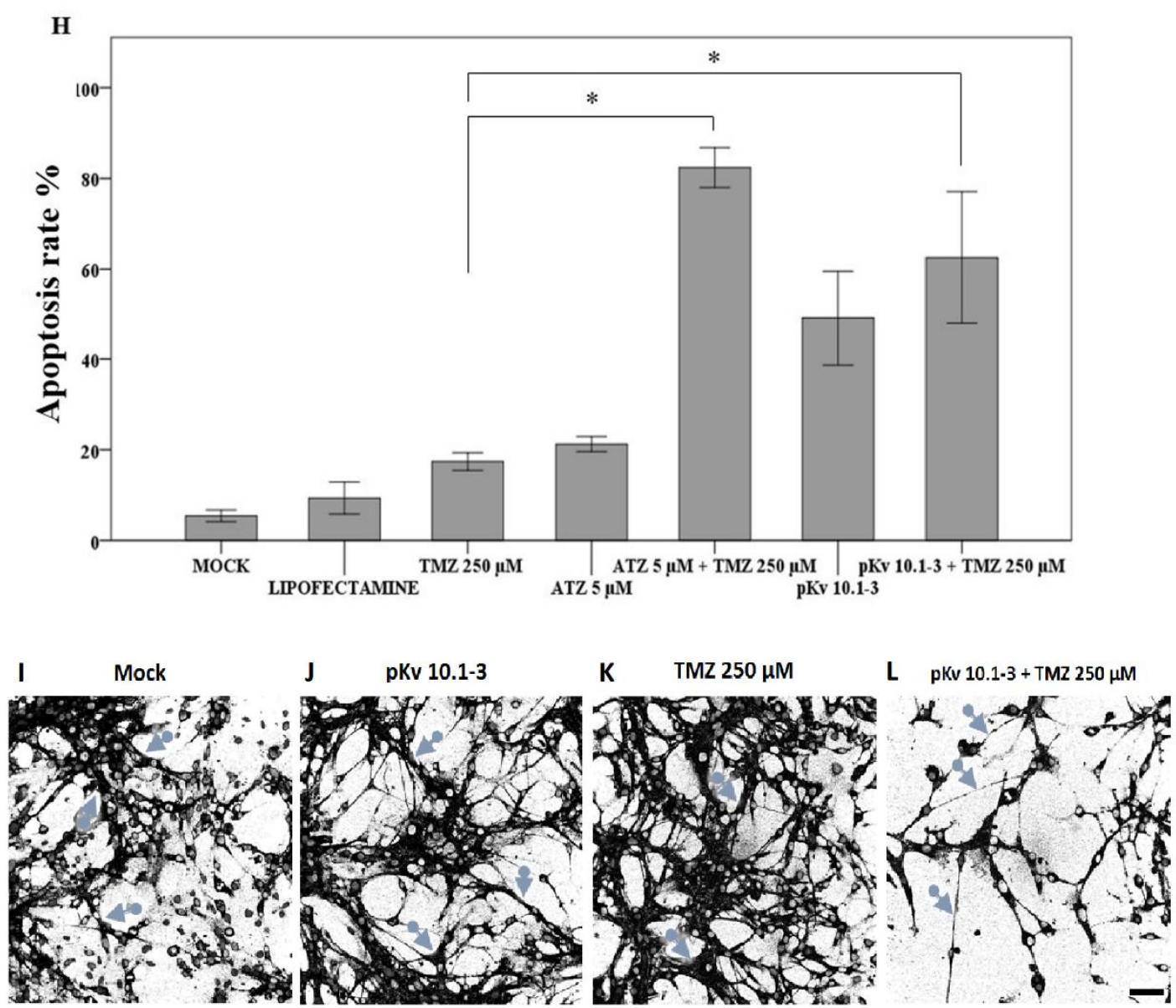

Figure 4. Induction of apoptosis by Eag1 suppression in U87MG glioblastoma cells exposed to TMZ. Experimental groups were analyzed at 72 hours by FACS Annexin V/propidium iodide (PI). The assay was performed according to the manufacturer's protocol. Representative scatter plots are showing the distribution of Annexin V-and PI-stained cells (A-G). The X-axis indicates PI fluorescence detected at 617 
$\mathrm{nm}$, and the Y-axis indicates Annexin V-FITC fluorescence detected at $488 \mathrm{~nm}$. The lower left (Q3) quadrant indicates live cells, the upper left (Q1) quadrants indicate necrotic cells, the upper right (Q2) quadrants indicate late apoptotic cells, and lower right (Q4) quadrant indicates early apoptotic cells. Average of sum between early and late apoptosis in U87MG cells $(\mathrm{H})$. Results were expressed as a percentage of total cell numbers, and represented as mean \pm SEM (bars). Assays were carried out in triplicate of three independent experiments. ${ }^{*} p<0.05$. Representative images acquired by confocal microscope (I-L). Binary images obtained by Phalloidin detection in U87MG monolayer cell culture, showing morphological changes caused by different treatments. Gray arrows points to differences in cell filaments between the group treated with the association of $\mathrm{pKv} 10.1-3$ and TMZ $250 \mu \mathrm{M}$ and the other groups $(\mathrm{I}-\mathrm{L})$. Scale bar $=20 \mu \mathrm{m}$.

\section{Discussion}

Ion channels play a critical role in tumorigenesis (28). They regulate the flux of ions across the plasma membrane, which influences cell cycle, growth and apoptosis (29). Thus, a deregulated activity or expression of ion channels will favor the loss of normal control of cell division, a classic hallmark of cancer (30). Previous work revealed that Eag1 potassium channels play a role in cell growth, neoplastic behavior and malignancy $(10,17)$. Many tumor types display a deregulated Eag1 function, including breast cancer cells (20), tumors of head and neck (31), colon (32,33), esophagus (34), cervix (35), and leukemia (36). Gliomas also overexpress Eag1, irrespective of their malignancy grade (12). In the present work, we confirmed that U87MG glioblastoma cells in culture display a high expression of Eag1 (Fig. 1E).

Those results confirmed a role for Eag1 in tumorigenesis, highlighting Eag1 as a promising target for anticancer therapy. However, as Eag1 plays a role in electrophysiology, restraint of channel work might cause adverse effects. In a previous study, an Eag1 knock-out mouse was developed and characterized (37). The animals showed no changes in embryogenesis, brain development, and electrical properties of cerebellar Purkinge cells; only mild behavioral changes occurred. Animals that lack an active channel showed no remarkable changes in physiology, thus we consider Eag1 is a safe and a promising target for cancer treatment. In fact, studies with monoclonal antibodies, siRNAs, astemizole and imipramine, have confirmed that Eag1 restraint can control cancer development $(18,21,23,38)$.

Astemizole is an antihistamine that also blocks the Eag1 channel. The drug showed activity against different cancer types, including hepatocellular carcinoma, breast tumors, and cervical cancer cells (39-41). Our results corroborated those findings, reinforcing the role of Eag1 in cancer cell growth. Astemizole caused a dose-dependent decrease in glioma cell viability, which remained for 24,48 and $72 \mathrm{~h}$ after treatment. The 
potential use of astemizole in cancer treatment, however, is hampered by its side effects (38). The drug may cause ventricular arrhythmia, a rare but potentially fatal toxic effect $(42,43)$. For brain tumors, a second pharmacological property of astemizole would also undermine its effectivity - the inability to penetrate the blood-brain barrier. Curiously, this pharmacokinetic is valuable for antihistamines to avoid sedation. In contrast, it is undesirable for drugs that must reach injured brain tissues, as occurs for infiltrating gliomas (44). The blood-brain tumor barrier also represents an obstacle for antiglioma chemotherapy. In the core part of glioblastomas this barrier is leaky, but in large parts it remains unchanged, blocking the access of anticancer drugs to tumor tissues (45). A new therapeutic strategy to inhibit Eag1 is an urgent demand.

In a previous work, synthetic small-interfering RNAs (siRNAs) showed the ability to silence Eag1 expression in various types of cancer cells (23). Glioma cells were not examined in that study. However, Eag1-targeted siRNAs decreased the Eag1 mRNA and protein contents, which resulted in a decreased growth of most cell types. Among the four siRNAs tested, Kv10.1-3 caused the highest silencing effect on Eag1. It targets the nucleotide sequence 1793-1813 of Eag1 mRNA (NM_172362). We employed the same Eag1 target sequence in the present study, which was cloned in a short-hairpin RNA expression vector named pKv10.1-3. We recently reported that glioma cells transfected with pKv10.1-3 were less viable than the controls (cells without treatment). Indeed, this Eag1 silencing vector also intensified interferon gamma cell damage on glioma cells (24). In the present work, we found that pKv10.1-3 sensitized glioma cells to TMZ, the drug of choice for treatment of glioblastoma multiforme. We observed that Eag1 plays a role in the cell damage caused by TMZ on glioma cells. First, Eag1 is highly expressed in glioma cells (Fig. 1E). Second, pKv10.1-3 in association with TMZ increased the silencing effect on Eag1 mRNA caused by TMZ alone (0.31 vs. 0.78 fold reduction; Fig. 1B and C). Third, the effect displayed by pKv10.1-3 on glioma cell viability at 24,48 , and $72 \mathrm{~h}$ was also found in a dose-dependent scale for astemizole, an Eag1 channel blocker (Fig. 2). Fourth, both treatments sensitized cells to TMZ injury; they decreased glioma cell viability, as found in pKv10.1-3 (63\% for pKv10.1-3 + TMZ vs. 34\% for $\mathrm{TMZ}$ alone) and astemizole (77\% for astemizole $+\mathrm{TMZ}$ vs. $46 \%$ for TMZ alone) (Fig. $3 \mathrm{~A}$ and B). Fifth, these treatments also caused changes in glioma cell morphology and poor adherence in culture flasks (Fig. 4I). Finally, both astemizole and pKv10.1-3 
significantly increased the rate of apoptosis caused by TMZ, as determined by flow cytometry (Fig. 4A-G).

The use of RNAi for Eag1 silencing was previously reported in other cancer cell lines. A viral vector expressing shRNAs to Eag1 also reduced tumor growth and angiogenesis of osteosarcoma (46). Indeed, small interfering RNAs to Eag1 sensitized ovarian cancer cells to cisplatin (47). No previous work has examined whether Eag1 gene silencing would sensitize glioma cells to TMZ.

In summary, our study reveals that suppression of Eag1 improves the action of TMZ on glioma cells. While pointing out a role for Eag1 in TMZ injury, our findings also project an anticancer strategy. A further study would test pKv10.1-3 in animal models of glioma, as a preclinical study to confirm if Eag1 is a target for an RNAi-based gene therapy.

\section{Acknowledgements}

This study received financial support from the Brazilian agencies FINEP, CAPES and CNPq.

\section{References}

1. Maher EA, Furnari FB, Bachoo RM, Rowitch DH, Louis DN, Cavenee WK, et al: Malignant glioma: genetics and biology of a grave matter. Genes Dev 15: 13111333, 2001.

2. Lassman AB: Molecular Biology of Gliomas. Curr Neurol Neurosci Rep 4: 228233, 2004.

3. Wen PY and Kesari S: Malignant Gliomas in Adults. N Engl J Med 359: 492-507, 2008.

4. Gladson CL, Prayson RA and Liu WM: The Pathobiology of Glioma Tumors. Annu Rev Pathol 5: 33-50, 2010.

5. Furnari FB, Fenton T, Bachoo RM, Mukasa A, Stommel JM, Stegh A, et al: Malignant astrocytic glioma: genetics, biology, and paths to treatment. Genes Dev 21: 2683-710, 2007.

6. Nagasawa DT, Chow F, Yew A, Kim W, Cremer N and Yang I: Temozolomide and Other Potential Agents for the Treatment of Glioblastoma Multiforme. Neurosurg Clin N Am 23: 307-22, 2012. 
7. Omuro A and DeAngelis LM: Glioblastoma and other malignant gliomas: a clinical review. JAMA 310: 1842-50, 2013.

8. Chamberlain MC: Temozolomide: Therapeutic Limitations in the Treatment of Adult High-Grade Gliomas. Expert Rev Neurother 10: 1537-44, 2010.

9. Pardo LA and Stümer W: The roles of $\mathrm{K}(+)$ channels in cancer. Nature 14: 39$48,2014$.

10. Pardo LA, del Camino D, Sánchez A, Alves F, Brüggemann A, Beckh S, et al: Oncogenic potential of EAG K+ channels. EMBO J 18: 5540-7, 1999.

11. Hemmerlein B, Weseloh RM, Queiroz FM, Knötgen H, Sánchez A, Rubio ME, et al: Overexpression of Eag1 potassium channels in clinical tumours. Mol Cancer 5: 41, 2006.

12. Patt S, Preussat K, Beetz C, Kraft R, Schrey M, Kalff R, et al: Expression of ether a go-go potassium channels in human gliomas. Neurosci Lett 368: 249-253. 2004.

13. Hermisson M, Klumpp A, Wick W, Wischhusen J, Nagel G, Roos W, et al: O6methylguanine DNA methyltransferase and p53 status predict temozolomide sensitivity in human malignant glioma cells. J Neurochem 96: 766-76, 2006.

14. Kim SS, Rait A, Kim E, Pirollo KF, Nishida M, Farkas N, et al: A nanoparticle carrying the p53 gene targets tumors including cancer stem cells, sensitizes glioblastoma to chemotherapy and improves survival. ACS Nano 8: 5494-514, 2014.

15. Lin H, Li Z, Chen C, Luo X, Xiao J, Dong D, et al: Transcriptional and posttranscriptional mechanisms for oncogenic overexpression of ether a go-go $\mathrm{K}+$ channel. PLoS One 6: e20362, 2011.

16. Essmann F and Schulze-Osthoff K: Translational approaches targeting the p53 pathway for anticancer therapy. Br J Pharmacol 165: 328-344, 2012.

17. Pardo LA and Stühmer W: EAG1: an emerging oncological target. Cancer Res 68: 1611-1613, 2008.

18. Gavrilova-Ruch O, Schönherr K, Gessner G, Schönherr R, Klapperstuck T, Wohlrab W, et al: Effects of imipramine on ion channels and proliferation of IGR1 melanoma cells. J Membr Biol 188: 137-149, 2002.

19. García-Ferreiro RE, Kerschensteiner D, Major F, Monje F, Stühmer W and Pardo LA: Mechanism of block of hEag1 $\mathrm{K}+$ channels by imipramine and astemizole. $\mathrm{J}$ Gen Physiol 124: 301-317, 2004. 
20. Roy J, Vantol B, Cowley EA, Blay J and Linsdell P: Pharmacological separation of hEAG and hERG $\mathrm{K}+$ channel function in the human mammary carcinoma cell line MCF-7. Oncol Rep 19: 1511-1516, 2008.

21. Gómez-Varela D, Zwick-Wallasch E, Knötgen H, Sánchez A, Hettmann T, Ossipov D, et al: Monoclonal antibody blockade of the human Eag1 potassium channel function exerts antitumor activity. Cancer Res 67: 7343-49, 2007.

22. Burnett JC and Rossi JJ: RNA-based therapeutic: current progress and future prospects. Chem Biol 19: 60-71, 2012.

23. Weber C, Mello de Queiroz F, Downie BR, Suckow A, Stühmer W and Pardo LA: Silencing the activity and proliferative properties of the human EagI Potassium Channel by RNA Interference. J Biol Chem 281: 13030-7, 2006.

24. Cunha LC, Del Bel E, Pardo L, Stühmer W and Titze-DE-Almeida R: RNA Interference with EAG1 Enhances Interferon Gamma Injury to Glioma Cells In Vitro. Anticancer Res 33: 865-870, 2013.

25. Kane A and Yang I: Interferon-gamma in brain tumor immunotherapy. Neurosurg Clin N Am 21: 77-86, 2010.

26. Mareschi K, Novara M, Rustichelli D, Ferrero I, Guido D, Carbone E, et al: Neural differentiation of human mesenchymal stem cells: evidence for expression of neural markers and each K+ channel type. Exp Hematol 34: 1563-1572, 2006.

27. Kwon MJ, Oh E, Lee S, Roh MR, Kim SE and Lee Y: Identification of novel reference genes using multiplatform expression data and their validation for quantitative gene expression analysis. PLoS One 4: e6162, 2009.

28. Kunzelmann K: Ion Channels and Cancer. J Membr Biol 205: 159-173, 2005.

29. Kondratskyi A, Kondratska K, Skryma R and Prevarskaya N: Ion channels in the regulation of apoptosis. Biochim Biophys Acta 1848(10 Pt B): 2532-46, 2014.

30. Lang F, Föller M, Lang KS, Lang PA, Ritter M, Gulbins E, et al: Ion channels in cell proliferation and apoptotic cell death. J Membr Biol 205: 147-157, 2005.

31. Menéndez ST1, Villaronga MA, Rodrigo JP, Alvarez-Teijeiro S, GarcíaCarracedo D, Urdinguio RG, et al: Frequent aberrant expression of the human ether a go-go (hEAG1) potassium channel in head and neck cancer: pathobiological mechanisms and clinical implications. J Mol Med (Berl) 90: 1173-1184, 2012. 
32. Ding XW, Yan JJ, An P, Lü P, Luo HS: Aberrant expression of ether a go-go potassium channel in colorectal cancer patients and cell lines. World J. Gastroenterol 13: 1257-1261, 2007.

33. Ousingsawat J, Spitzner M, Puntheeranurak S, Terracciano L, Tornillo L, Bubendorf L, et al: Expression of voltage-gated potassium channels in human and mouse colonic carcinoma. Clin. Cancer Res. 13: 824-31, 2007.

34. Ding XW, Luo HS, Jin X, Yan JJ, Ai YW: Aberrant expression of Eag1 potassium channels in gastric cancer patients and cell lines. Med. Oncol. 24: 345-350, 2007.

35. Ortiz CS, Montante-Montes D, Saqui-Salces M, Hinojosa LM, GamboaDominguez A, Hernández-Gallegos E, et al: Eag1 potassium channels as markers of cervical dysplasia. Oncol. Rep. 26: 1377-1383, 2011.

36. Agarwal JR, Griesinger F, Stühmer W, Pardo LA: The potassium channel Ether a go-go is a novel prognostic factor with functional relevance in acute myeloid leukemia. Mol. Cancer 9: 18, 2010.

37. Ufartes R, Schneider T, Mortensen LS, de Juan Romero C, Hentrich K, Knoetgen $\mathrm{H}$, et al: Behavioural and functional characterization of Kv10.1 (Eag1) knockout mice. Hum Mol Genet 22: 2247-62, 2013.

38. García-Quiroz J, Camacho J: Astemizole: an old anti-histamine as a new promising anti-cancer drug. Anticancer Agents Med Chem 11: 307-14, 2011.

39. de Guadalupe Chávez-López M, Pérez-Carreón JI, Zuñiga-García V, DíazChávez J, Herrera LA, Caro-Sánchez $\mathrm{CH}$, et al: Astemizole-based anticancer therapy for hepatocellular carcinoma (HCC), and Eag1 channels as potential early-stage markers of HCC. Tumour Biol 36: 6149-58, 2015.

40. García-Quiroz J, García-Becerra R, Santos-Martínez N, Barrera D, Ordaz-Rosado D, Avila E, et al: In vivo dual targeting of the oncogenic Ether-à-go-go-1 potassium channel by calcitriol and astemizole results in enhanced antineoplastic effects in breast tumors. BMC Cancer 14: 745, 2014.

41. de Guadalupe Chávez-López M, Hernández-Gallegos E, Vázquez-Sánchez AY, Gariglio P, Camacho J: Antiproliferative and proapoptotic effects of astemizole on cervical cancer cells. Int J Gynecol Cancer 24 :824-8, 2014.

42. de Abajo FJ and Rodríguez LA: Risk of ventricular arrhythmias associated with nonsedating antihistamine drugs. Br J Clin Pharmacol 47: 307-13, 1999. 
43. Oppenheimer JJ and Casale TB: Next generation antihistamines: therapeutic rationale, accomplishments and advances. Expert Opin Investig Drugs 11: 807$17,2002$.

44. González MA, Estes KS: Pharmacokinetic overview of oral second-generation H1 antihistamines. Int J Clin Pharmacol Ther. 36: 292-300, 1998.

45. van Tellingen O, Yetkin-Arik B, de Gooijer MC, Wesseling P, Wurdinger T, de Vries HE: Overcoming the blood-brain tumor barrier for effective glioblastoma treatment. Drug Resist Updat 19: 1-12, 2015.

46. Wu J, Wu X, Zhong D, Zhai W, Ding Z, Zhou Y: Short Hairpin RNA (shRNA) Ether à go-go 1 (Eag1) inhibition of human osteosarcoma angiogenesis via VEGF/PI3K/AKT signaling. Int J Mol Sci 13: 12573-83, 2012.

47. Hui C, Lan Z, Yue-Li L, Li-Lin H, Li-Lin H: Knockdown of Eag1 Expression by RNA Interference Increases Chemosensitivity to Cisplatin in Ovarian Cancer Cells. Reprod Sci pii: 1933719115590665, 2015. 


\section{Contribuições da Pesquisa}

O presente trabalho desenvolveu e avaliou o modelo GL261/CX3CR1, dedicado a estudar a interação do glioma com a micróglia. Este modelo possibilitou o acompanhamento de diversas características da ativação microglial intermediada pelas células de glioma, e revelou detalhes sobre a comunicação célula-célula em camundongos imunocompetentes. As técnicas de microscopia utilizadas permitiram novas abordagens direcionadas à análise de imagens, fornecendo uma avaliação quantitativa da ativação microglial e da migração destas células em direção à massa tumoral. O modelo GL261/CX3CR1 apresentou diversas vantagens, permitindo a monitorização da interação micróglia-glioma 1- longitudinalmente; 2- in loco; 3- com boa resolução celular; 4- a partir de tecidos fixados ou animais vivos; 5- sem a necessidade de imunodetecção; 6- em escalas de tempo de minutos a semanas. Em resumo, o método proposto fornece uma técnica rápida, que permite a análise de grandes conjuntos de dados adquiridos em vários pontos temporais.

Com ajuda do modelo GL261/CX3CR1, observou-se que havia expressão do canal de potássio Kv 10.1 na interação do glioma com a micróglia. A partir do conhecimento da presença deste canal no microambiente tumoral, infiltrado pela micróglia, o presente estudo possibilitou elucidar que as células de glioma em cultura liberam fatores que aumentam a expressão do Kv 10.1 em células microgliais e elevam a sua viabilidade.

Da mesma maneira, nosso estudo revela que a supressão do canal Kv 10.1 melhora a ação da temozolomida em células de glioma. Lançando luz sobre o papel do Kv 10.1 nas respostas do glioma a este tratamento de escolha, projeta-se uma estratégia anticancerígena inovadora para desenvolvimento biotecnológico. 


\section{Conclusões gerais e perspectivas}

\section{Conclusões}

1. O modelo GL261/CX3CR1, devidamente implementado e validado, mostrou-se como ferramenta valiosa nos estudos sobre a processo infiltrativo da micróglia na massa tumoral de glioma.

a. A micróglia, quando atraída pelas células de glioma, altera sua morfologia, passando da forma ramificada para amebóide. Essas mudanças puderam ser quantificadas adequadamente pelo modelo desenvolvido no presente estudo;

b. As técnicas de análise de imagens empregadas no atual trabalho forneceram informações consistentes, com boa qualidade de definição e, portanto, úteis ao estudo da interação micróglia-glioma.

2. Células de glioma são capazes de liberar fatores solúveis que aumentam a expressão do canal de potássio Kv 10.1 em células de micróglia em cultivo.

a. O aumento da expressão de RNAm do canal Kv 10.1 é acompanhado pelo aumento da imunodetecção da proteína;

b. Este aumento de Kv 10.1 ocorre paralelamente ao aumento da viabilidade em células de micróglia em cultivo, o que sugere que este canal tenha papel na comunicação célula-célula.

3. O canal de potássio $\mathrm{Kv}$ 10.1, quando inibido, potencializa os efeitos da temozolomida no processo de morte celular.

\section{Perspectivas}

1. Avaliar o papel do $\mathrm{Kv} 10.1$ na interação glioma-micróglia no modelo GL261/CX3CR1, mediante técnicas de silenciamento gênico;

2. Elucidar se miRNAs e exossomos participam da interação célula-célula, desta forma regulando o canal $\mathrm{Kv} 10.1$;

3. Avaliar se os efeitos de potencialização da TMZ, via supressão de $\mathrm{Kv}$ 10.1, ocorrem in vivo. 


\section{Anexos}

\section{Anexo 1 - The role of neuronal nitric oxide synthase enzyme (nNOS) in the cell damage of glioblastoma cells caused by temozolomide}

Fernando Francisco Borges Resende $^{1 *}$; Simoneide Souza Titze-de-Almeida ${ }^{1 *}$; Ricardo Titze-de-Almeida ${ }^{1}$.

${ }^{1}$ Technology for Gene Therapy Laboratory, University of Brasilia (UnB), Brasília, Brazil.

* Both authors contributed equally to this work.

Submetido à Oncology letters - fator de impacto 1.55, qualis B1 - Medicina Veterinária. 


\section{Abstract}

Glioblastoma multiforme (GBM) is the most prevalent primary brain tumor. Treatment for GBM includes radiotherapy, chemotherapy with temozolomide (TMZ), and surgical ablation. Despite some therapeutic advances, the survival time of patients with GBM is no longer than 12-14 months. About tumor biology, cancer cells overexpress the neuronal isoform of the nitric oxide synthase (nNOS). In the present study, we examined whether nNOS enzyme plays a role in the cell damage of glioma cells caused by TMZ. First, TMZ $250 \mu \mathrm{M}$ triggered an increase in oxidative stress at 2, 48 and $72 \mathrm{~h}$ in glioblastoma cell lines U87MG, U251MG and U138MG, as revealed by DCFH-DA assay. The drug also reduced the cell viability, as measured by 3-(4,5-dimethylthiazol-2-y1)-2,5diphenyltetrazolium bromide (MTT). U87MG cells presented a more linear decline in cell viability in time-points $2 \mathrm{~h}, 48 \mathrm{~h}$ and $72 \mathrm{~h}$. The peak of oxidative stress occurred at $48 \mathrm{~h}$. To examine the role of nitric oxide synthase (NOS) enzymes in the cell damage of temozolomide (TMZ), we used N( $\omega)$-nitro-L-arginine methyl ester (L-NAME) and 7Nitroindazole (7-NI). L-NAME increased the cell damage of TMZ on glioma cells, while reducing the oxidative stress at $48 \mathrm{~h}$. The preferential nNOS inhibitor, 7-NI, also improved the TMZ effects. It caused a $12.8 \%$ decrease in the viability of TMZ-injured cells. Indeed, 7-NI was more effective than L-NAME in restraining the increase in oxidative stress triggered by TMZ. Silencing nNOS with a synthetic siRNA (siRNAnNOShum_4400) increased by $20 \%$ the effects of TMZ $250 \mu \mathrm{M}$ on cell viability $(\mathrm{P}<0.05)$. nNOS knock-down also enhanced the rate of apoptosis triggered by TMZ. Taking together, our data reveal that nNOS enzymes play a role in the cell damage of TMZ on glioma cells. RNAi with nNOS merits further studies in animal models to disclose its potential use in glioma anticancer therapy.

\section{Introduction}

Glioblastoma multiforme (GBM) is the most frequent and malignant primary brain tumor. The prognosis for patients with glioma is poor, with a median survival of 12 - 14 months (HENSON, 2006; OSTROM et al., 2013). A standard therapy for GBM consists of maximal safe resection of the tumor mass followed by radio- and chemotherapy (STUPP et al., 2007). The drug of choice is temozolomide (TMZ), but the treatment yields a median survival benefit of only 2.5 months. In addition, tumor recurrence and resistance 
to temozolomide often occur (PEDRETTI et al., 2010; SATHORNSUMETEE; RICH, 2006).

Cancer cells commonly present an increased metabolic activity, which results in oxidative stress (CAIRNS; HARRIS; MAK, 2011; KARDEH; ASHKANI-ESFAHANI; ALIZADEH, 2014). The precise role of oxidative stress in tumor biology and its implication in cancer therapy remains a complex matter. The excessive levels of reactive oxygen molecules (ROS) may result in cell damage and apoptosis (NOGUEIRA; HAY, 2013). However, ROS production, which includes nitric oxide (NO), may improve survival, growth, and the neoplastic phenotype found in cancer cells, including gliomas (CONTI et al., 2010; KIM; KWON; NAKANO, 2014).

Neuronal nitric oxide enzymes (nNOS) synthesize the largest amount of NO in the body, exerting an important role for homeostasis (MONCADA; BOLAÑOS, 2006). However, nNOS and NO are also involved in brain diseases and cancer pathogenesis (LUO; ZHU, 2011; THOMSEN; MILES, 1998). In general, brain tumors and peritumoral areas express nitric oxide synthases (NOS), which improves the blood supply need for cancer development (BAKSHI et al., 1998; FUKUMURA; JAIN, 1998). NO formed by nNOS contributes to angiogenesis, vasodilation, and vascular permeability, thus playing a role in tumor growing and malignancy (TANRIOVER et al., 2008). Also, the nonselective NOS inhibitor L-NAME controlled glioma growth in a rat model (SWAROOP et al., 2000).

In summary, oxidative stress is a biochemical change that affects tumor growth and cancer cell's response to antineoplastic drugs. Disclosing molecules that regulate oxidative stress in TMZ-injured glioma cells will enrich our knowledge on tumor biology and responses to anticancer therapy. In this study, we examined whether nNOS enzymes play a role in the effects of TMZ on glioma cells.

\section{Materials and methods}

Cell culture. Human glioblastoma cell lines U87MG, U251MG and U138MG were maintained in DMEM/F12 [supplemented with 10\% (volume/volume) heat-inactivated fetal bovine serum, $1 \%$ GlutaMAX $^{\mathrm{TM}}$ all obtained from Gibco (New York, USA), $1 \%$ of penicillin/streptomycin solution and $250 \mathrm{ng} / \mathrm{mL}$ amphotericin B (Sigma Aldrish, Madrid, Spain)]. The cells were seeded into flasks and maintained at $37{ }^{\circ} \mathrm{C}$ in a humidified atmosphere with $5 \% \mathrm{CO}_{2}$. 
Determination of cell viability. Glioma cells were seeded in 96-well plates at a concentration of $0.5 \times 10^{4}$ cells/well. Details on each experimental procedure are present in the figure legends. The cells were incubated with $200 \mu \mathrm{M}$ of $\mathrm{N}(\omega)$-nitro-L-arginine methyl ester (L-NAME) or $100 \mu \mathrm{M}$ of 7-Nitroindazole (7-NI) 1 hour before the addition of temozolomide (TMZ) $250 \mu \mathrm{M}$. After a specific time of treatment, cell viability was measured by a quantitative colorimetric assay with 3-(4,5-dimethylthiazol-2-y1)-2,5diphenyltetrazolium bromide (MTT), which shows the mitochondrial activity of living cells. Briefly, $50 \mu \mathrm{L}$ of the MTT-labeling reagent $(0.5 \mathrm{mg} / \mathrm{mL})$ were added to each well, and the plate was incubated for an additional $3 \mathrm{~h}$ period. The insoluble formazan was dissolved with dimethylsulfoxide, and the MTT reduction was measured at $595 \mathrm{~nm}$ in an absorbance plate reader SpectraMax ${ }^{\circledR}$ M2 (Molecular Devices, California, USA). Control cells without treatment were taken as $100 \%$ viability. To determine the effects of nNOS gene silencing by siRNAs on cell viability, we also used the MTT assay. For that, glioma cells mixed with $200 \mu \mathrm{L}$ of the supplemented DMEM/F12 were first cultured for $24 \mathrm{~h}$. Then, the first medium was removed and replaced by Opti-MEM ${ }^{\circledR}$ (Gibco, New York, USA) without supplements. Transfection of siRNAnNOShum_4400 was carried out by using Lipofectamine ${ }^{\circledR} 2000$, according to the manufacturer's instructions (Invitrogen, California, USA). Twenty-four hours later, the Opti-MEM ${ }^{\circledR}$ was removed and replaced by the supplemented DMEM/F12. Then we added TMZ to achieve a $250 \mu \mathrm{M}$ final concentration. After $48 \mathrm{~h}$ of incubation, cell viability was determined by the MTT assay.

Reactive oxygen species (ROS) test. The $2^{\prime}, 7^{\prime}$-dichlorfluorescein-diacetate (DCFH-DA) assay was used to measure ROS production in glioma cells. Briefly, cells were seeded in 96-well plates at a concentration of $0.5 \times 10^{4}$ cells/well. After $24 \mathrm{~h}$, the cells were treated with TMZ $250 \mu \mathrm{M}$ for $2 \mathrm{~h}, 48 \mathrm{~h}$ or $72 \mathrm{~h}$. Specific groups received L-NAME or 7-NI one hour before TMZ cell damage. Following that, the medium was removed and cells were incubated with DCFH-DA at a final concentration of $20 \mu \mathrm{M}$ in DMEM/F12, for $30 \mathrm{~min}$ at $37^{\circ} \mathrm{C}$, and washed with DPBS. DCFH-DA levels were measured in a microplate reader SpectraMax ${ }^{\circledR}$ M2 (Molecular Devices, California, USA) with excitation and emission wavelengths set at 485 and $535 \mathrm{~nm}$, respectively.

Synthetic siRNAs. This study used a previously described small-interfering RNA (siRNA) to silence nNOS mRNA, found by the Biopredsi algorithm (HUESKEN et al., 2005; TITZE-DE-ALMEIDA et al., 2014). SiRNAnNOShum_4400 recognizes a 
nucleotide sequence present in exon 28 of all nNOS splicing variants $\alpha, \beta$, and $\gamma\left(5^{\prime}\right.$ GCGAACGTACGAAGTGACCAA - 3’; nt 4898 - 4918, NM_000620.2). It was synthesized by Qiagen as double-stranded RNA sequences with 21 nucleotides. This study also used the AllStars ${ }^{\circledR}$ Negative Control siRNA (Qiagen, California, USA).

Cell transfection. Transfections of three different glioblastoma lineages (U87MG, U251MG and U138MG) with siRNAnNOShum_4400 were carried out with Lipofectamine ${ }^{\circledR} 2000$ Transfection Reagent (Invitrogen, California, USA) and Opti$\operatorname{MEM}^{\circledR}$ (Gibco, New York, USA), according to the manufacturer's instructions.

\section{Reverse transcription real-time quantitative polymerase chain reaction (RT-qPCR).}

First, total RNA was extracted with the RNeasy ${ }^{\circledR}$ Mini Kit (Qiagen, Hilden, Germany) following the manufacturer's instructions, and quantified by fluorometry (Qubit ${ }^{\circledR}$, Invitrogen, California, USA). The purity was considered acceptable for RNA/protein ratios above 1.8 RNA integrity was analyzed by agarose gel electrophoresis. The cDNA synthesis was performed from $500 \mathrm{ng}$ total RNA, by using random primers (SuperScript ${ }^{\circledR}$ First-Strand Synthesis System for RT-PCR, Invitrogen, California, USA). Real time PCR reaction was carried out in a 7500 Fast Real-Time PCR (Applied Biosystems ${ }^{\circledR}$, California, USA). The forward and reverse primers for nNOS were 5' GGTGGAGATCAATATCGCGGTT - 3' and 5' - CCGGCAGCGGTACTCATTCT 3' (DÖTSCH et al., 2000). For the housekeeping gene, we used the GC-rich promoter binding protein 1 (GPBP1) primers 5' - TCACTTGAGGCAGAACACAGA - 3' and 5' AGCACATGTTTCATCATTTTCAC - 3' (KWON et al., 2009). Amplification products were detected via intercalation of the fluorescent dye SYBR $^{\circledR}$ Green (Applied Biosystems $^{\circledR}$, California, USA). Briefly, $10 \mu \mathrm{L}$ reaction mix contained $5.0 \mu \mathrm{L}$ Fast SYBR $^{\circledR}$ Green Master mix, $2.0 \mu \mathrm{L}$ of cDNA diluted 1:10, and $0.4 \mu \mathrm{L}$ each sense and antisense primer $(10 \mathrm{pmol} / \mu \mathrm{L})$. The PCR program included an initial denaturation at 95 ${ }^{\circ} \mathrm{C}$ for $5 \mathrm{~min}$, followed by 40 cycles of amplification $\left(95^{\circ} \mathrm{C}\right.$ for $1 \mathrm{~min}, 60{ }^{\circ} \mathrm{C}$ for $1 \mathrm{~min}$ ). Each run was carried out in triplicate, and the assay included non-template negative RT controls. Delta delta $\mathrm{Ct}\left(2^{-\Delta \Delta \mathrm{Cq}}\right)$ relative quantification method was used to express the RNAi effects on nNOS message content (LIVAK; SCHMITTGEN, 2001).

Nuclear staining with Hoechst 33342. Hoechst 33342 staining was used to detect cells in apoptosis. GBM cells were cultured in 24-well plates, and transfected with 
siRNAnNOShum_4400 as above described. After $24 \mathrm{~h}$, cells received TMZ for $48 \mathrm{~h}$. We also included injured and nontransfected cell groups, as positive controls. Briefly, the cells were fixed in $4.0 \%$ paraformaldehyde for $10 \mathrm{~min}$ before staining with Hoechst $33342(5.0 \mu \mathrm{g} / \mathrm{mL}) /$ well in the dark for $10 \mathrm{~min}$, at room temperature. Subsequently, the coverslips were washed twice with PBS, air-dried, mounted onto glass slides and observed under a fluorescence microscope. The nuclear condensation, fragmentation, and bright staining of apoptotic cells were identified by intense local staining in the nucleus, in contrast to the diffused staining of DNA in normal cells.

Statistical analysis. Statistical package for social sciences (SPSS) version 17 (IBM, New York, USA) was used to analyze our data. All results were expressed as means \pm standard error of the means (SEM). One-way analysis of variance (ANOVA) with Tukey's posttest was applied to test inter-group differences. Differences between paired groups were analyzed by the Student t test. $P$ values of $<0.05$ were considered significant.

\section{Results}

The present work evaluated whether nitric oxide synthase enzymes (NOS) play a role in the cell damage caused by TMZ on GBM cell lines. We first examined the effects of TMZ $250 \mu \mathrm{M}$ on oxidative stress and glioma cell viability. They were evaluated in three cell lines (U87MG, U251MG and U138MG) at $2 \mathrm{~h}, 48 \mathrm{~h}$, and $72 \mathrm{~h}$. Then we investigated whether NOS enzymes would affect the cell damage caused by TMZ. For that, L-NAME (a nonspecific NOS inhibitor) and 7-NI (a nNOS inhibitor) were used. Finally, we applied a second strategy - RNA interference, to explore the involvement of nNOS enzyme in such cell responses.

TMZ affects glioma cell viability and increases oxidative stress. All glioblastoma cell lines exposed to TMZ $250 \mu \mathrm{M}$ presented a decreased cell viability with higher levels of ROS. These effects varied in intensity according to the time-points and cell lines studied. As shown in Figure 1A, TMZ caused a progressive decline in cell viability at $2 \mathrm{~h}, 48 \mathrm{~h}$ or $72 \mathrm{~h}$ in U87MG cells. The values varied from $92 \%$ ( $2 \mathrm{~h})$ to $52 \%(72 \mathrm{~h})$, and they were significantly different. The cells produced ROS at increased levels, reaching the peak at $48 \mathrm{~h}(* \mathrm{P}<0.05)$. On U251MG cells, TMZ caused the highest cell damage at $48 \mathrm{~h}$ (Fig. 1B). Compared to other cell lines, the differences in cell viability among time points $2 \mathrm{~h}$, $48 \mathrm{~h}$, and $72 \mathrm{~h}$ were mild (84\%-88\%) and not statistically significant. The highest 
oxidative stress response in U251MG cells was found at $72 \mathrm{~h}$ post-TMZ. Finally, TMZ caused a progressive reduction in U138MG cell viability, with a parallel increase in ROS production (Fig. $1 \mathrm{C} ; * \mathrm{P}<0.05$ ). Both effects peaked at $72 \mathrm{~h}$ post-TMZ.
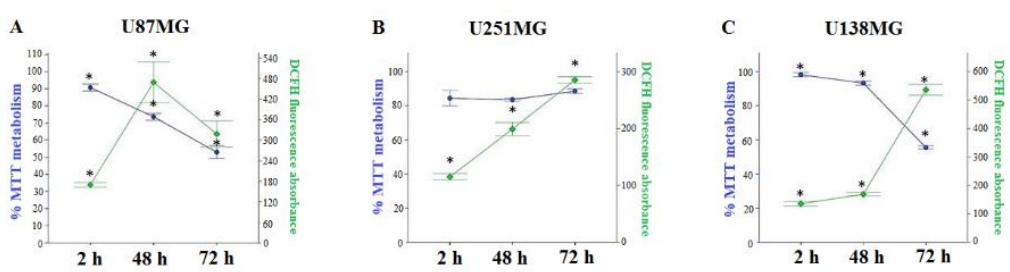

Figure 1. TMZ reduced the viability of U87MG, U251MG, and U138MG cell lines, and increased their oxidative stress. Experiments were carried out in triplicate, in eight independent assays. Circles and squares represent mean values \pm SEM regarding MTT or DCFH assay results in each time-point. GBM cells were injured by TMZ $250 \mu \mathrm{M}$ for $2 \mathrm{~h}, 48 \mathrm{~h}$ or $72 \mathrm{~h}$. TMZ affected cell viability and the production of ROS, as determined by MTT and DCFH assays, respectively. From $2 \mathrm{~h}$ to $48 \mathrm{~h}$ post-TMZ, all cell lines showed a significant reduction in cell viability along with an increase in oxidative stress response. Asterisks represent statistically significant differences $(* \mathrm{P}<0.05$, ANOVA one-way followed by Tukey's test).

nNOS-targeted siRNAs reduced nNOS mRNA content in glioma cell lines. The present assay was carried out to evaluate whether the enzyme nNOS could be silenced by RNA interference. For that, we examined the effect of a previously described siRNAnNOShum_4400 $(37.5 \mathrm{nM})$ on nNOS mRNA content, at $24 \mathrm{~h}$ post-transfection. All transfected glioblastoma cell lines, U87MG, U251MG, and U138MG presented their content of nNOS mRNA reduced to about $50 \%$ at $24 \mathrm{~h}$ (Fig. 2). This strategy to suppress nNOS expression will be further employed to examine the role of this enzyme in TMZ injured glioma cells.

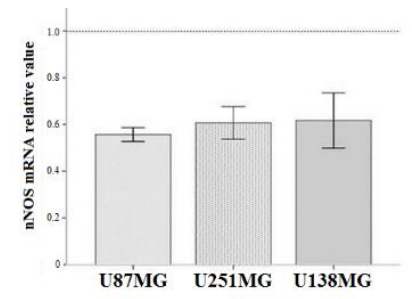

Figure 2. Effects of siRNAnNOShum_4400 on nNOS mRNA content of U87MG, U251MG and U138MG cells. Cells were transfected with siRNAnNOShum_4400 (37.5 nM) mixed with Lipofectamine ${ }^{\circledR} 2000$ for $24 \mathrm{~h}$. RT-qPCR results were presented as the relative expression to the scramble control group $\left(2^{-\Delta \Delta C q}\right)$. 
Bars represent the fold changes in nNOS mRNA to the control group, arbitrarily assigned the value 1. siRNAnNOShum_4400 reduced the content of nNOS mRNA in glioma cells.

\section{Effects of NO synthase inhibitors on cell viability and oxidative stress of U87MG}

cells exposed to TMZ for $48 \mathrm{~h}$. Inhibiting NOS enzymes cause effects on TMZ cell damage at $48 \mathrm{~h}$. As shown in Figure 3A, L-NAME and 7-NI decreased the viability of TMZ-damaged U87MG cells by $9.6 \%$ and $12.8 \%$, respectively $(* \mathrm{P}<0.05)$. In parallel, the inhibitors also hampered the increase in ROS production caused by TMZ (Fig. 3B; $* \mathrm{P}<0.05)$. As noted, 7-NI was more effective than L-NAME to improve the effects of TMZ, as well as in controlling the oxidative stress response. These data highlight a relevant role for nNOS in the actions of TMZ against glioma cells.

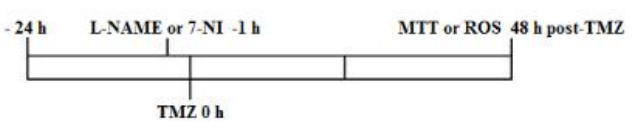

$\mathbf{A}$

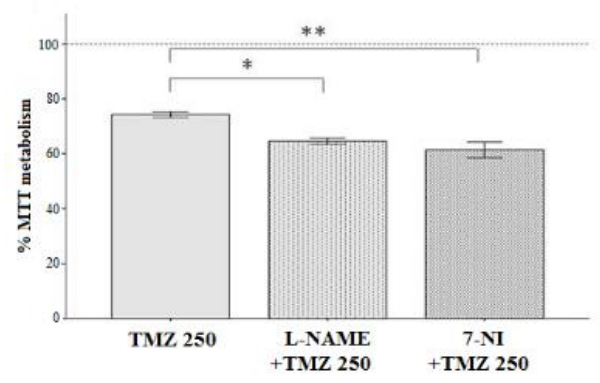

B

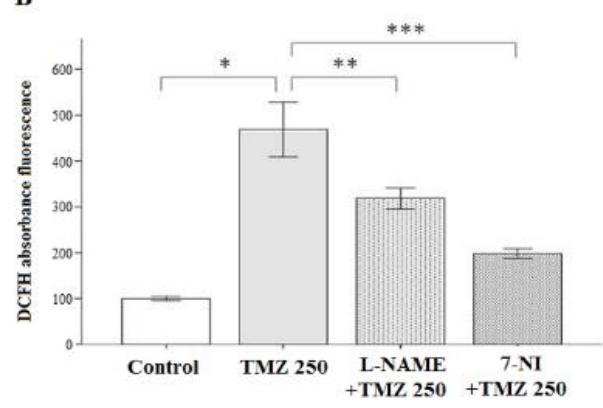

Figure 3. Effects of NOS inhibition in U87MG glioma cells exposed to TMZ for $48 \mathrm{~h}$. Cell viability and ROS production were measured by the MTT and DCFH-DA assays, respectively. Bars express mean \pm SEM regarding MTT or DCFH assays. Experiments were carried out in triplicate, in eight independent assays. At the top, we present a schematic representation of the experimental procedure. Briefly, either LNAME or 7-NI was added to cell preparations 1 hour before TMZ treatment. Then the cells received TMZ $250 \mu \mathrm{M}$ at the time point $0 \mathrm{~h}$. They were incubated for an additional period of $48 \mathrm{~h}$, following to the MTT and DCFH-DA assays. Pretreatment with L-NAME $(200 \mu \mathrm{M})$ or 7-NI $(100 \mu \mathrm{M})$ in cells injured by TMZ reduced their viability (A) and decreased ROS production (B). Asterisks represent statistically significant differences $(* \mathrm{P}<0.05$, ANOVA one-way followed by Tukey's test). 
nNOS-targeted siRNAs potentiated the effects of TMZ. We knocked-down nNOS enzyme by using siRNAnNOShum_4400, transfected $24 \mathrm{~h}$ before TMZ cell damage. This siRNA alone caused no significant changes in glioma cell viability. However, siRNAtransfected cells were more susceptible to the effects of TMZ at $48 \mathrm{~h}$. They presented an additional $20 \%$ decrease in viability compared to the injured mock-transfected group $(70 \%$ versus $50 \%$; *P<0.05) (Fig. $4 \mathrm{~A})$. Cell groups damaged by a higher TMZ concentration $(500 \mu \mathrm{M})$ also presented the same response $(44 \%$ versus $26 \%$; $* \mathrm{P}<0.05)$ (Fig. 4B).
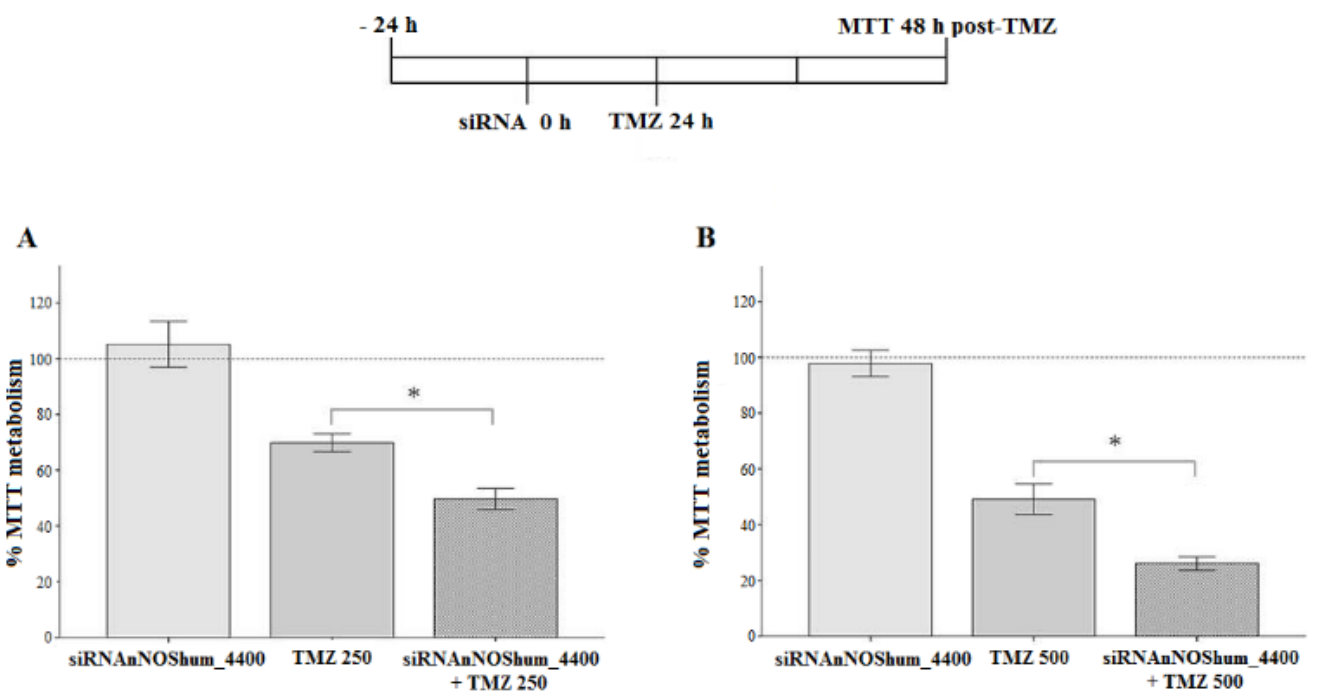

Figure 4. Effects of siRNAnNOShum_4400 on the viability of U87MG cells injured by TMZ. Bars express mean \pm SEM regarding MTT assays. Glioma cells were first transfected with siRNAnNOShum_4400 (37.5 $\mathrm{nM})$ for $24 \mathrm{~h}$. Then cells received TMZ $(250 \mu \mathrm{M}$ or $500 \mu \mathrm{M})$. Cell viability was determined at $48 \mathrm{~h}$ postTMZ by MTT in four independent assays. Bars represent the absorbance values found in treated groups normalized to the mock control group (hatched line). ${ }^{*} \mathrm{P}<0.05$ (ANOVA one-way followed by Tukey's test) for the following groups: pretreated with siRNAnNOShum_4400 followed by TMZ $250 \mu \mathrm{M}$ versus TMZ $250 \mu \mathrm{M}$ (A); pretreated with siRNAnNOShum_4400 followed by TMZ $500 \mu \mathrm{M}$ versus TMZ $500 \mu \mathrm{M}$ (B). siRNAnNOShum_4400 improved the effects of TMZ on glioma cells, for both drug concentrations.

nNOS-targeted siRNAs increase the apoptosis of glioblastoma cells damaged by TMZ. This experimental section focused on apoptosis-induced glioma cell death. We first found that TMZ $250 \mu \mathrm{M}$ alone could trigger the apoptosis of U87MG cells, as determined by the Hoechst assay (Fig. 5A). Silencing nNOS enzyme with 
siRNAnNOShum_4400 caused no increase in GBM cell apoptosis. However, glioblastoma cells silenced from nNOS were more susceptible to have their apoptosis triggered by TMZ. As shown in Figure 5B, the rate of apoptosis caused by TMZ was significantly higher in the group transfected with nNOS-targeted siRNAs $(* \mathrm{P}<0.05)$.

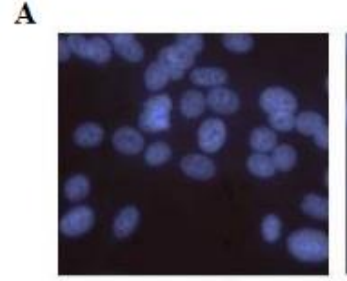

Control

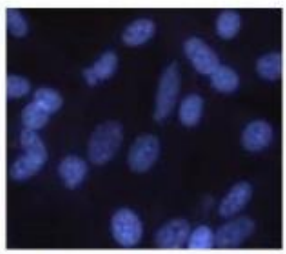

SiRNAnNOShum_4400

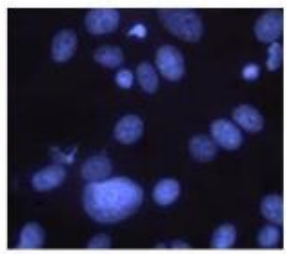

TMZ 250

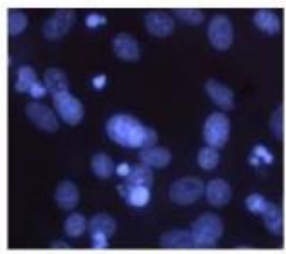

siRNAnNOShum_4400 + TMZ 250

B

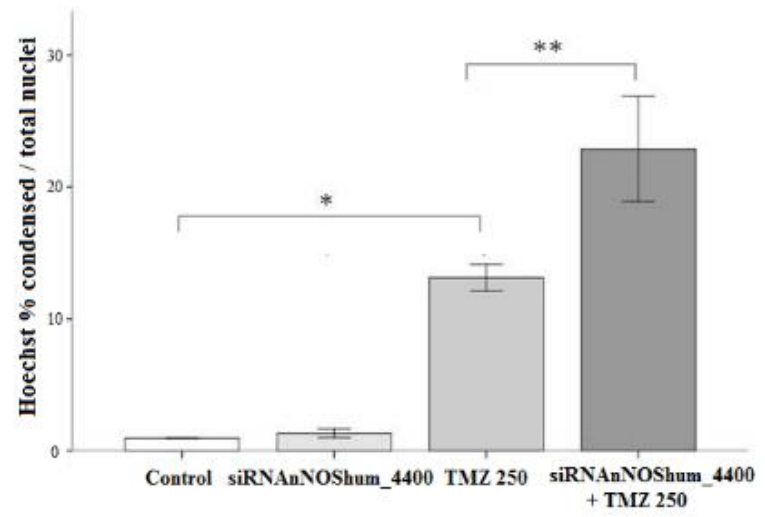

Figure 5. Effects of siRNAnNOShum_4400 on the apoptosis of U87MG cells induced by TMZ. Bars express mean \pm SEM regarding Hoechst 33342 nuclear staining results. Experiments were carried out in triplicate, in 8-12 independent assays. Treatments and time points correspond to that presented in Fig. 4 panel. Briefly, apoptosis was examined in cells injured by TMZ $250 \mu \mathrm{M}$ for $24 \mathrm{~h}$. Transfected cell groups received siRNAnNOShum_4400 $(37.5 \mathrm{nM})$ for $24 \mathrm{~h}$, mixed with Lipofectamine ${ }^{\circledR} 2000$. One of them was exposed to TMZ $250 \mu \mathrm{M}$. Apoptosis was examined at the time point $48 \mathrm{~h}$ post-TMZ. TMZ $250 \mu \mathrm{M}$ induced glioma cell apoptosis, which was reinforced by the previous treatment with siRNAnNOShum_4400. $* \mathrm{P}<0.05$, TMZ $250 \mu \mathrm{M}$ versus control (ANOVA one-way followed by Tukey's test). $* * \mathrm{P}<0.05$, pretreated with siRNAnNOShum_4400 followed by TMZ $250 \mu \mathrm{M}$ versus TMZ $250 \mu \mathrm{M}$ (ANOVA one-way followed by Tukey’s test).

\section{Discussion}

Growing evidence has implied NOS enzymes in the biology of tumor cells (JIA; JACKSON-COOK; GRAF, 2010; MUNTANÉ; LA MATA, 2010; SIKORA et al., 2010). This work examined whether nNOS enzymes affect glioma cell responses to TMZ cell damage. 
TMZ acts by forming $\mathrm{O}^{6}$-methylguanine nucleotides, which mispairs with thymine during DNA replication. In consequence, the drug causes a cell-cycle arrest in $\mathrm{G}_{2} / \mathrm{M}$ phase in glioma cells, which finally induces cell death (SANG; LI; LAN, 2014). TMZ also reduces the membrane potential of the mitochondria, releases cytochrome $c$ from this organelle, and increases activated caspases 3 and 9 cell content (JAKUBOWICZ-GIL et al., 2013a). Indeed, studies with U87MG cells reported an increase in ROS production at two and four hours post TMZ. This oxidative stress contributes to TMZ effects on glioma cells, as confirmed by a protective effect obtained with the antioxidant $\mathrm{N}$-acetylcysteine. Also, TMZ $300 \mu \mathrm{M}$ caused a 10-fold increase in ROS levels in TMZ-sensitive U251MG cells, but no effect occurred on resistant ones (OLIVA et al., 2011). Our study used TMZ at $250 \mu \mathrm{M}$. The drug increased oxidative stress in glioma cell lines U87MG, U251MG, and U138MG. The peak of ROS concentration occurred at $48 \mathrm{~h}$ or $72 \mathrm{~h}$, according to each cell line (Fig. 1). Corroborating previous studies, cell groups with increased levels of ROS showed a lower cell viability (OLIVA et al., 2011; ZHANG et al., 2010).

The gas nitric oxide (NO) contributes to oxidative stress in gliomas (CONTI et al., 2010). NO is often referred as a toxic and reactive molecule. However, it inhibits the apoptosis of glioma cells associated with caspase 3-like enzymes, via S-nitrosylation or through a cGMP-dependent pathways (BLAISE et al., 2005). At micromolar concentration, it also inhibits catalase and cytochrome P-450 enzymes (BRUNELLI; YERMILOV; BECKMAN, 2001; WINK et al., 1993). NO is delivery during the synthesis of L-citrulline, catalyzed by NOS enzymes (KIM; KWON; NAKANO, 2014). This gaseous molecule will form two metabolites, nitrite and nitrate (MONCADA; BOLAÑOS, 2006). Nitrite damages DNA strands, leading to various biochemical features found in cancer cells like changes in p53 activity and epidermal growth factor signaling (COBBS et al., 2003; XU et al., 2002; ZHANG et al., 2000). The increased NOS activity reported in glioma cells also contributes to oxidative stress (CONTI et al., 2010; WINK et al., 1993). In the same sense, inhibiting NOS enzymes by L-NAME will result in a lower nitrite concentration in rat glioma tumor tissues. This inhibitor also decreases tumor volume, which reinforces the benefits of reducing NOS activity in glioma cells (OYOSHI et al., 2003; SWAROOP et al., 2000). No previous work, however, has addressed the involvement of NOS enzymes in the cell damage of glioma cells caused by TMZ. In our study, we pretreated cells with L-NAME to evaluate the resulting effects on oxidative stress and viability. We found that NOS enzymes affect 
both responses. L-NAME sensitized U87MG cells to TMZ $250 \mu \mathrm{M}$. The viability of glioma cells and oxidative stress were decreased at the time point $48 \mathrm{~h}$. Taking together, these data reveal that NOS enzymes contribute to oxidative stress in glioblastoma cells injured by TMZ. We might speculate that inhibition of NOS enzymes during TMZ cell damage may converge to the same apoptotic pathway described above, improving the damage of glioma cells.

The neuronal isoform of NOS enzymes (nNOS) is highly expressed in gliomas. Expression of nNOS occurs in both the tumor and peritumoral areas of glioma (BAKSHI et al., 1998). Indeed, tumors with high histological grades also present higher levels of nNOS expression (BROHOLM et al., 2003; TANRIOVER et al., 2008). Although these findings suggest a possible role for $\mathrm{nNOS}$ in gliomagenesis, no previous work has addressed its involvement in glioma cells injured by TMZ. Our study tested the nNOS inhibitor 7-NI and a synthetic siRNA targeting nNOS. At $48 \mathrm{~h}, 7-\mathrm{NI}$ decreased the viability of U87MG, restraining the oxidative stress response to TMZ $250 \mu \mathrm{M}$ (Fig. 3). The place of nNOS enzyme in glioma cell responses to TMZ was confirmed by RNAi experiments. U87MG cells silenced from nNOS for $24 \mathrm{~h}$ were more vulnerable to TMZ. They showed a lower viability with and increased rate of apoptosis (Fig. 4 and 5). Results from nNOS knock-down reinforces the other ones obtained with the nNOS inhibitor 7NI, suggesting the enzyme plays at least a partial role in glioma cell defenses against TMZ.

TMZ is the standard chemotherapeutic agent for malignant glioma. Tumor recurrence and drug resistance unfortunately often occur, and the mean survival period is about 12-14 months (HENSON, 2006). To increase the efficacy of TMZ, recent studies have associated this drug with structures that silence critical genes for tumor biology. Heat shock proteins (Hsp27 and Hsp72), Src kinases, and the GTPase-activating protein RLIP76 are examples of targets for RNAi that improve TMZ effects on glioma cells (JAKUBOWICZ-GIL et al., 2013b; WANG et al., 2013a, 2013b). In the present study, we showed a new target for RNAi - the nNOS enzyme, which also improved anticancer effects of TMZ on glioma cells. The synthetic duplex for silencing nNOS, siRNAnNOShum_4400, merits further studies to explore its potential use for glioma anticancer therapy. 


\section{Acknowledgements}

The present research received financial support from CAPES, CNPq, and FAP-DF.

\section{Conflict of interests}

The nNOS sequence used for designing siRNAnNOShum_4400 is under patent registration at the Brazilian Institute for Industrial Property - "Instituto Nacional da Propriedade Industrial”, INPI.

\section{References}

BAKSHI, A. et al. The expression of nitric oxide synthases in human brain tumours and peritumoral areas. Journal of the neurological sciences, v. 155, n. 2, p. 196-203, 5 mar. 1998.

BLAISE, G. A. et al. Nitric oxide, cell signaling and cell death. Toxicology, v. 208, n. 2, p. 177-92, 15 mar. 2005.

BROHOLM, H. et al. Nitric oxide synthase expression and enzymatic activity in human brain tumors. Clinical neuropathology, v. 22, n. 6, p. 273-81, 2003.

BRUNELLI, L.; YERMILOV, V.; BECKMAN, J. S. Modulation of catalase peroxidatic and catalatic activity by nitric oxide. Free radical biology \& medicine, v. 30, n. 7, p. 709-14, 1 abr. 2001.

CAIRNS, R. A.; HARRIS, I. S.; MAK, T. W. Regulation of cancer cell metabolism. Nature reviews. Cancer, v. 11, n. 2, p. 85-95, mar. 2011.

COBBS, C. S. et al. Inactivation of wild-type p53 protein function by reactive oxygen and nitrogen species in malignant glioma cells. Cancer research, v. 63, n. 24, p. 86703, 15 dez. 2003.

CONTI, A. et al. Role of inflammation and oxidative stress mediators in gliomas. Cancers, v. 2, n. 2, p. 693-712, jan. 2010.

DÖTSCH, J. et al. Gene expression of neuronal nitric oxide synthase and adrenomedullin in human neuroblastoma using real-time PCR. International journal of cancer. Journal international du cancer, v. 88 , n. 2, p. 172-5, 15 out. 2000.

FUKUMURA, D.; JAIN, R. K. Role of nitric oxide in angiogenesis and microcirculation in tumors. Cancer metastasis reviews, v. 17, n. 1, p. 77-89, mar. 1998. 
HENSON, J. W. Treatment of glioblastoma multiforme: a new standard. Archives of neurology, v. 63, n. 3, p. 337-41, mar. 2006.

HUESKEN, D. et al. Design of a genome-wide siRNA library using an artificial neural network. Nature biotechnology, v. 23, n. 8, p. 995-1001, ago. 2005.

JAKUBOWICZ-GIL, J. et al. Apoptosis induction in human glioblastoma multiforme T98G cells upon temozolomide and quercetin treatment. Tumour biology : the journal of the International Society for Oncodevelopmental Biology and Medicine, v. 34, n. 4, p. 2367-78, ago. 2013a.

JAKUBOWICZ-GIL, J. et al. Silencing of Hsp27 and Hsp72 in glioma cells as a tool for programmed cell death induction upon temozolomide and quercetin treatment. Toxicology and applied pharmacology, v. 273, n. 3, p. 580-9, 15 dez. 2013b.

JIA, W.; JACKSON-COOK, C.; GRAF, M. R. Tumor-infiltrating, myeloid-derived suppressor cells inhibit $\mathrm{T}$ cell activity by nitric oxide production in an intracranial rat glioma + vaccination model. Journal of neuroimmunology, v. 223, n. 1-2, p. 20-30, jun. 2010.

KARDEH, S.; ASHKANI-ESFAHANI, S.; ALIZADEH, A. M. Paradoxical action of reactive oxygen species in creation and therapy of cancer. European journal of pharmacology, v. 735, p. 150-68, 15 jul. 2014.

KIM, S.-H.; KWON, C.-H.; NAKANO, I. Detoxification of oxidative stress in glioma stem cells: Mechanism, clinical relevance, and therapeutic development. Journal of neuroscience research, v. 92, n. 11, p. 1419-24, nov. 2014.

KWON, M. J. et al. Identification of novel reference genes using multiplatform expression data and their validation for quantitative gene expression analysis. PloS one, v. 4, n. 7, p. e6162, jan. 2009.

LIVAK, K. J.; SCHMITTGEN, T. D. Analysis of relative gene expression data using real-time quantitative PCR and the 2(-Delta Delta C(T)) Method. Methods (San Diego, Calif.), v. 25, n. 4, p. 402-8, dez. 2001.

LUO, C.-X.; ZHU, D.-Y. Research progress on neurobiology of neuronal nitric oxide synthase. Neuroscience bulletin, v. 27, n. 1, p. 23-35, fev. 2011.

MONCADA, S.; BOLAÑOS, J. P. Nitric oxide, cell bioenergetics and neurodegeneration. Journal of neurochemistry, v. 97, n. 6, p. 1676-89, jun. 2006. 
MUNTANÉ, J.; LA MATA, M. DE. Nitric oxide and cancer. World journal of hepatology, v. 2, n. 9, p. 337-44, 27 set. 2010.

NOGUEIRA, V.; HAY, N. Molecular pathways: reactive oxygen species homeostasis in cancer cells and implications for cancer therapy. Clinical cancer research : an official journal of the American Association for Cancer Research, v. 19, n. 16, p. 4309-14, 15 ago. 2013.

OLIVA, C. R. et al. Acquisition of chemoresistance in gliomas is associated with increased mitochondrial coupling and decreased ROS production. PloS one, v. 6, n. 9, p. e24665, jan. 2011.

OSTROM, Q. T. et al. CBTRUS statistical report: Primary brain and central nervous system tumors diagnosed in the United States in 2006-2010. Neuro-oncology, v. 15 Suppl 2, p. ii1-56, nov. 2013.

OYOSHI, T. et al. Pathodynamics of nitric oxide production within implanted glioma studied with an in vivo microdialysis technique and immunohistochemistry. Journal of pharmacological sciences, v. 91, n. 1, p. 15-22, jan. 2003.

PEDRETTI, M. et al. Combination of temozolomide with immunocytokine F16-IL2 for the treatment of glioblastoma. British journal of cancer, v. 103, n. 6, p. 827-36, 7 set. 2010.

SANG, D.-P.; LI, R.-J.; LAN, Q. Quercetin sensitizes human glioblastoma cells to temozolomide in vitro via inhibition of Hsp27. Acta pharmacologica Sinica, v. 35, n. 6, p. 832-8, jun. 2014.

SATHORNSUMETEE, S.; RICH, J. N. New treatment strategies for malignant gliomas. Expert review of anticancer therapy, v. 6, n. 7, p. 1087-104, jul. 2006.

SIKORA, A. G. et al. Targeted inhibition of inducible nitric oxide synthase inhibits growth of human melanoma in vivo and synergizes with chemotherapy. Clinical cancer research : an official journal of the American Association for Cancer Research, v. 16, n. 6, p. 1834-44, 15 mar. 2010.

STUPP, R. et al. Chemoradiotherapy in malignant glioma: standard of care and future directions. Journal of clinical oncology : official journal of the American Society of Clinical Oncology, v. 25, n. 26, p. 4127-36, 10 set. 2007.

SWAROOP, G. R. et al. The effects of chronic nitric oxide synthase suppression on 
glioma pathophysiology. British journal of neurosurgery, v. 14, n. 6, p. 543-8, dez. 2000.

TANRIOVER, N. et al. Neuronal nitric oxide synthase expression in glial tumors: correlation with malignancy and tumor proliferation. Neurological research, v. 30, n. 9, p. $940-4$, nov. 2008.

THOMSEN, L. L.; MILES, D. W. Role of nitric oxide in tumour progression: lessons from human tumours. Cancer metastasis reviews, v. 17, n. 1, p. 107-18, mar. 1998.

TITZE-DE-ALMEIDA, S. S. et al. Interferon Gamma Potentiates the Injury Caused by MPP(+) on SH-SY5Y Cells, Which is Attenuated by the Nitric Oxide Synthases Inhibition. Neurochemical research, 9 out. 2014.

WANG, Q. et al. Knockdown of RLIP76 expression by RNA interference inhibits invasion, induces cell cycle arrest, and increases chemosensitivity to the anticancer drug temozolomide in glioma cells. Journal of neuro-oncology, v. 112, n. 1, p. 73-82, mar. 2013a.

WANG, Z. et al. Downregulation of Src enhances the cytotoxic effect of temozolomide through AKT in glioma. Oncology reports, v. 29, n. 4, p. 1395-8, abr. 2013 b.

WINK, D. A. et al. Reactions of the bioregulatory agent nitric oxide in oxygenated aqueous media: determination of the kinetics for oxidation and nitrosation by intermediates generated in the $\mathrm{NO} / \mathrm{O} 2$ reaction. Chemical research in toxicology, v. 6 , n. 1, p. 23-7, 1993.

XU, W. et al. The role of nitric oxide in cancer. Cell research, v. 12, n. 5-6, p. 311-20, dez. 2002.

ZHANG, P. et al. Peroxynitrite targets the epidermal growth factor receptor, Raf-1, and MEK independently to activate MAPK. The Journal of biological chemistry, v. 275, n. 29, p. 22479-86, 21 jul. 2000.

ZHANG, W. et al. Activation of AMP-activated protein kinase by temozolomide contributes to apoptosis in glioblastoma cells via p53 activation and mTORC1 inhibition. The Journal of biological chemistry, v. 285, n. 52, p. 40461-71, 24 dez. 2010. 


\section{Anexo 2 - Patente BR 102012 032844-5 A2 - Pequenos RNAs interferentes e insertos para expressão desses RNAs para inibição da expressão da enzima óxido nítrico sintase neuronal; métodos e usos em associação com IFN- $\gamma$ ou neomicina para tratamento de distúrbios neurológicos}

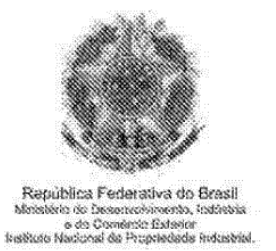

(21) BR 102012 032844-5 A2

(22) Data de Depósito: 21/12/2012

(43) Data da Publicação: 17/03/2015

(RPI 2306)
(54) Título: PEQUENOS RNAs INTERFERENTES E INSERTOS PARA EXPRESSÃO DESSES RNAS PARA INIBIÇÃO DA EXPRESSÃO DA ENZIMA ÓXIDO NITRICO SINTASE NEURONAL; MÉTODOS E USOS EM ASSOCIAÇÃO COM IFN-y OU NEOMICINA PARA TRATAMENTO DE DISTÚRBIOS NEUROLÓGICOS

(51) Int.Cl.: C12N15/113; A61K48/00; A61P25/28

(73) Titular(es): Fundação Universidade de Brasilia, Universidade de São Paulo - USP

(72) Inventor(es): CÁTIA VALDERÊS DOS SANTOS FARIA LUSTOSA, ELAINE APARECIDA DEL BEL BELLUZ GUIMARÃES, FERNANDO FRANCISCO BORGES RESENDE, FATIMA MARIA CAETANO CALDEIRA, LINUS DE QUEIROZ PEREIRA, NADIA RUBIA FERREIRA, RICARDO TITZE DE ALMEIDA, SIMONEIDE SOUZA SILVA, FERNANDO FRANCISCO BORGES RESENDE, FATIMA MARIA CAETANO CALDEIRA
(57) Resumo: PEQUENOS RNAs INTERFERENTES E INSERTOS PARA EXPRESSAO DESSES RNAS PARA INIBIÇAO DA EXPRESSAO DA ENZIMA ÓXIDO NITRICO SINTASE NEURONAL; METODOS E USOS EM ASSOCIAÇAO COM IFN-y OU NEOMICINA PARA TRATAMENTO DE DISTÚRBIOS NEUROLÓGICOS. A presente invenção refere-se a construtos de nucleotideos, denominados de duplex, grampos e insertos capazes de promover interferência de RNA sobre o RNA mensageiro (RNAm) da enzima óxido nítrico sintase neuronal (nNOS), reduzindo a sua expressão. Adicionalmente a invençäo também se refere a um método para inibição da expressão do RNAm da enzima nNOS que causa, em consequência, efeitos de redução da viabilidade de células tumorais de glioma e melhora da viabilidade de células dopaminérgicas submetidas a injúria. Outro aspecto da invenção consiste na utilização dos insertos para clonagem e expressão em vetores plasmidiais visando a obtenção de RNAs capazes de provócar interferência de RNA sobre a enzima nNOS. Além disso, os construtos da invenção uma vez utilizados em associação comneomicina e INF-'y mostram potencial para tratamento de distúrbios neurológicos. 


\section{Anexo 3 - Potential role of neuronal nitric oxide synthase isoform in the onset of intervertebral disc degeneration}

Vitor Castania ${ }^{1}$, Ana Carolina Issy ${ }^{1,4}$, João Walter Silveira ${ }^{1}$, Frederico Rogério Ferreira ${ }^{2,4}$, Simoneide S Titze-de-Almeida ${ }^{3}$, Fernando F B Resende ${ }^{3}$, Nádia Rubia Ferreira ${ }^{1}$, Ricardo Titze-de-Almeida ${ }^{3}$, Helton L A Defino ${ }^{5}$, Elaine Del Bel ${ }^{1,4 *}$

1- Department of Morphology, Physiology and Basic Pathology, Dental School, University of São Paulo (USP), Ribeirão Preto, Brazil

2- Oswaldo Cruz Foundation (FIOCRUZ), Rio de Janeiro, Brazil

3- Technology for Gene Therapy Laboratory, University of Brasilia - UnB/FAV, Brasília, DF, Brazil

4- Center for Interdisciplinary Research on Applied Neurosciences (NAPNA), University of São Paulo (USP), Brazil

5- Department of Biomechanics, Medicine and Rehabilitation of the Locomotor Apparatus, School of Medicine, University of São Paulo (USP), Ribeirão Preto, Brazil

Submetido ao Journal of Orthopaedic Research - fator de impacto 2.98, qualis A2 Medicina Veterinária. 


\begin{abstract}
Intervertebral disc degeneration is a progressive and debilitating disease with multifactorial causes. Nitric oxide (NO) might contribute to the cell death pathway. We evaluated the presence of the constitutive form of the neuronal NOS (nNOS) in both health and degenerated intervertebral disc through qPCR and immunohistochemistry. We also analyzed the potential role of nNOS modulation in the tail needle puncture model of intervertebral disc degeneration. Male Wistar rats were submitted to percutaneous disc puncture with a 21-gauge needle of coccygeal vertebras. The selective nNOS pharmacological inhibitor N( $\omega)$-propyl-L-arginine (NPLA) or a nNOS-target siRNA (siRNAnNOShum_4400) were injected immediately after the intervertebral disc puncture with a 30-gauge needle. Signs of disc degeneration were analyzed by in vivo MR imaging and histological score. We found that intact intervertebral discs express low levels of nNOS mRNA. Disc injury caused a 4 fold increase in nNOS mRNA content at 5 hours post disc lesion. However, NPLA or nNOS-target siRNA slight mitigate the intervertebral disc degenerative progress. Our data show evidence of the nNOS presence in the intervertebral disc and its upregulation during degeneration. Further studies would disclose the nNOS role and its potential therapeutical value in the intervertebral disc degeneration.
\end{abstract}

Key words: Nitric Oxide, Intervertebral disc degeneration, Animal Model, nNOS, siRNA. 


\section{Introduction}

Intervertebral disc degeneration is a multifactorial disorder. Several aspects have been associated with its etiology, including genetic predisposing factors, aging, mechanical loading, environmental factors and their interaction (1). The intervertebral disc is composed of two interdependent tissues, a thick outer ring of fibrous cartilage (collagen I) termed the annulus fibrosus which surrounds the nucleus pulposus a more gelatinous core composed by sparse chondrocytes surrounded by an extracellular matrix of collagen II and the proteoglycan aggrecan. Except for the outermost annulus fibrosus, the normal intervertebral disc is both avascular and aneural (2).

Among others, nitric oxide (NO) is suggested as a biochemical mediator that plays a role in the intervertebral disc pathogenesis (2-5). Studies have shown that herniated cervical intervertebral discs produce NO, and elevated production of NO has been found in cerebrospinal fluid of patients with degenerative lumbar disease $(2,4,5)$. NO is a small molecule with a short half-life that regulates several biological functions. Mammals produce NO thought three genetically different, but closely related NO synthase (NOS) isoforms, which have the same active site and catalyze the same reaction. Molecular cloning has shown that these isoforms share 50-60\% of homology (6). Neuronal (nNOS) and endothelial (eNOS) isoforms are constitutive and activated by the calciumcalmodulin complex (7). Both nNOS and eNOS are mainly expressed in brain/spinal cord, and in vascular tissue, respectively (7). The inducible form (iNOS) is insensible to calcium influx and has the expression regulated by cell receptors for inflammatory cytokines (8). Increased levels of NO possibly will play key roles in the onset of disc degradation, as follows: (i) collagen type II and aggrecan synthesis inhibition; (ii) metalloproteinases increasing; (iii) restraint of chondrocyte proliferation; and (iv) chondrocyte apoptosis (9-14).

No work examined the role of constitutive NOS in the disc degeneration. Noteworthy, the neurogenesis and the angiogenesis are tissue changes associated with advanced disc degeneration process (1). In addition, constitutive NOS activation seems to be implicated in the mechanical forces modulation of the disc degeneration (15). To study the implication of NO production in the disc degeneration the present study has the following aims: (i) to examine the nNOS expression in healthy and degenerated discs, using a rat model of induced disc degeneration; and (ii) to evaluate the impact of nNOS inhibition in the intervertebral disc degeneration. 


\section{Material and Methods}

2.1 Animals. All experiments were conducted in accordance with the National Institute of Health Guidelines for Welfare of Experimental Animals. The methodology was approved by the Ethics Committee of the University of São Paulo/FORP. Male Wistar rats $(\mathrm{n}=42)$ weighing $300-350 \mathrm{~g}$ were used in this study. The animals were housed in groups of four and kept at a controlled temperature of $23{ }^{\circ} \mathrm{C}( \pm 1)$ with a $12-12 \mathrm{~h}$ light-dark cycle. Food and drinking water were available ad libitum.

The study was carried out in three steps. In the first step the nNOS isoform was detected in the normal and induced-degenerated discs of the Wistar rat at coccygeal region. In the second step, we assessed the effects of the pharmacological inhibition of nNOS on induced-degenerated discs. The third study phase addressed the effects of a synthetic small interfering RNA (siRNA) against nNOS in the same rat model. Levels of gene silencing were quantified in both in vitro and in vivo tests.

2.2 Surgical protocol. In all surgical procedures, the animals were anesthetized with an intraperitoneal (i.p.) injection of ketamine $(50 \mathrm{mg} / \mathrm{kg}$ ) and xylazine $(5 \mathrm{mg} / \mathrm{kg})$. The same protocol was used for magnetic resonance imaging (MRI). Three coccygeal intervertebral spaces Co6-7, Co7-8 and Co8-9 were chosen for this study. To induce the rat disc degeneration, a needle puncture model was carefully standartizated. The intervertebral level Co7-8 remained undisturbed as the control level. The coccygeal intervertebral levels Co6-7 and Co8-9 were identified by digital palpation and confirmed by fluoroscopy. After tail skin antisepsis with iodate alcohol, a 21-gauge needle was inserted through the annulus fibrosus crossing the nucleus pulposus until the contralateral annulus fibrosus. Depth of needle penetration was controlled by the resistance of the contralateral annulus fibrosus. Then the needle was twice rotated $360^{\circ}$, and held for 30 seconds before extraction (16).

2.3 Intradiscal injection procedure. Intradiscal injection was performed in the second and third phases of the study, immediately after the puncture disc procedure. The injection

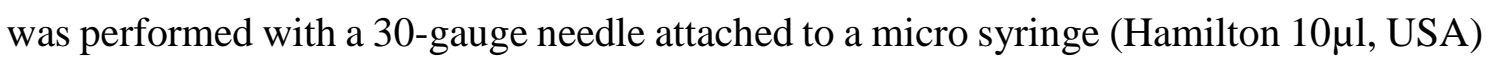
by using an infusion pump interposed by a polyethylene catheter (PE10) at $1 \mu \mathrm{l} / \mathrm{min}$. The needle was left for an additional 3 min period to prevent reflux. All therapeutic agents (nNOS inhibitor or nNOS target siRNA) were injected in the proximal punctured 
intervertebral disc (Co6-7). The intervertebral space Co7-8 remained undisturbed and did not receive any treatment. The distal punctured disc Co8-9 received the control solution. For all procedures the total injected volume was $2 \mu 1$. The effects of this injection volume were previously described as innocuous to the tail intervertebral discs of rats (17).

2.4 Magnetic resonance acquisition and analysis. The MRI was performed under general anesthesia to guarantee immobility 2 days after the intervertebral disc puncture. Additionally, animals that received nNOS-target siRNA were resubmitted to the MRI at 21 days post-operative. Imaging was acquired using a 3-Tesla MR scanner (Achieva, Phillips ${ }^{\circledR}$; The Netherlands) using a dedicated coil for small animals. The tail was inserted into a tube containing a $0.1 \mathrm{M} \mathrm{CuSO} 4$ solution to increase the image contrast. A 2-D spin-echo, dual echo sequence was obtained with the following parameters: repetition time $=9000 \mathrm{~ms}$; echo times $=16$ (proto density) and 80 (T2-weigthed) $\mathrm{ms}$; flip angle $=$ 90 ; number of averages $=2$; slice thickness $=0.6 \mathrm{~mm}$; field of view $=40 \times 40 \mathrm{~mm}$; in plane resolution $=0.1 \mathrm{~mm} ; 30$ sagittal slices. A linear combination of both proto density and T2-weigthed images showed excellent anatomical details and it was used to perform a qualitative evaluation of disc integrity. As the method provides an indirect measure of disc hydration, decrease in water content correlates with signal loss on T2-weighted MRIs, and would thus represent the degree of intervertebral disc degeneration (18). The analyses were conducted using the public domain image analysis program developed by the U.S. National Institutes of Health - Image J. MRI analyses were calculated from 4-5 sequential sagittal images of intervertebral discs and the mean pixel intensity value was quantified.

2.5 Histological analysis. Animals were euthanized at 2 or 21 days after the tail needle puncture and treatment (pharmacological blocking or siRNAs, respectively) by excess anesthesia with ketamine/xylazine. The whole discs with the vertebrae adjacent to the punctured segments (Co6-7 and Co8-9) and non-punctured segment (Co7-8) were

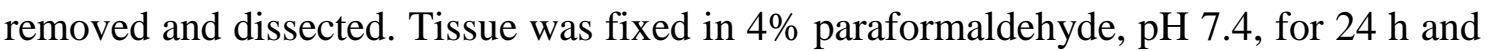
decalcified in ETDA (hydrochloric acid 12\%, EDTA $0.07 \%$, sodium tartrate $0.014 \%$, potassium and sodium tartrate $0.8 \%$ and water) during 24 hours, paraffin-embedded, and sectioned to 5-mm thickness with a microtome. Midsagittal sections were prepared for 
mounting and staining hematoxylin and eosin and nNOS immunohistochemistry respectively.

Hematoxylin and eosin histological score was graded in a blinded fashion, using the definition established by Norcross and coworkers (2003) (19), with some modifications, under a light microscope (Leica®) at a magnification of 10X (20). The histological grading scale ranged from 1 (several degenerated disc) to 5 (normal disc) and was assigned separately to both annulus fibrosus and nucleus pulposus. This histological scale mainly scores the disruption of nucleus pulposus central cavity and collagen fiber orientation of annulus fibrosus. For nucleus pulposus the better score (5) is attribute to a large central cavity with abundant nucleus pulposus material (intervertebral disc height > $2 / 3$ ), and the worse score (1) to the complete obliteration of central cavity and absence of cells. The collagen fiber orientation of annulus fibrosus is ranging to the well-opposite lamellae (score 5) to severe fragmentation (score 1).

2.6 Part I: nNOS detection. The nNOS isoform was examined in healthy and induceddegenerated coccygeal discs of Wistar rats $(n=20)$. Real time quantitative polymerase chain reaction (qPCR) and immunohistochemistry were used for mRNA and protein detection, respectively. The qPCR was performed at $5 \mathrm{~h}, 24 \mathrm{~h}$ or 5 days post-lesion. An immunohistochemical analysis was performed at 48 hours post-lesion. The induceddegenerated (Co6-7 and Co8-9) and control (Co7-8) discs were obtained from euthanized animals at different time points.

2.6.1 qPCR. Total RNA was extracted by the Trizol method (Invitrogen, Carlsbad, CA, USA). CDNA was obtained from $1 \mu \mathrm{g}$ of total RNA with a High-capacity cDNA kit, according to the manufacturer's instructions (Applied Biosystem, Foster City, CA, USA). Relative nNOS expression was quantified with StepOne real-time PCR system, using Applied Biosystems real-time master mix with Taqman ${ }^{\circledR}$ gene expression probes (nNOSAssay ID Rn01646679). Expression of nNOS was normalized based on Ct values for the GAPDH housekeeping gene (Assay ID Rn01749022_g1). All reactions were triplicated, and fold change was calculated by using the $2-\Delta \mathrm{Ct}$ method.

2.6.2 Immunohistochemistry. The immunohistochemical analysis was performed using a standard peroxidase-based method. Polyclonal primary antibodies anti-nNOS were 
purchased from Santa Cruz Biotechnology (Sc- 648) or gently provided by P. Emson (Cambridge, UK). They were tested at different concentrations (Sc- 648: 1:250 or 1:500; P. Emson: 1:2000, 1:4000 or 1:8000). Tissue sections were deparaffinized by rinsing in xylene (2 times; 10 min each) hydrated with ethanol series (100-30\%, 5-2 min each) and washed in distilled water. Antigen retrieval was performed by heating the slides for 30 min in a water bath at $50{ }^{\circ} \mathrm{C}$ in $10 \mathrm{mM}$ citrate buffer solution $\mathrm{pH}$ 6.0. Afterward, the slides were allowed to cool down to room temperature for at least 1 hour. To remove endogenous peroxidase activity, tissue sections were pre-incubated for 10 min in $3 \%$ hydrogen peroxide in PBS 0.1M. Non-specific binding sites were blocked with 5\% BSA in PBS 0.1M for 1 hour. After each step, slides were rinsed with PBS 0.1 M (3 times; 5 min each). Subsequently, the slides were incubated with the anti-nNOS primary antibody during 48 hours. Then, sections were successively washed (PBS 0.1 M) and incubated in a secondary antibody solution (PBS) for $90 \mathrm{~min}$, which contained the biotinylated antirabbit antibody (1:400; Vector Laboratories, Burlingame, CA). Next, the sections were incubated with the avidin-biotin immunoperoxidase method for 2 hours (1:300; Vectastain ABC kit, Vector Lab, Burlingame, CA, U.S.A.), and then nNOS immunoreactivity was revealed by the addition of chromogen diaminobenzidin (DAB; Sigma) with or without nickel.

\subsection{Part II: Intradiscal nNOS inhibition through the pharmacological inhibitor.} Under general anesthesia, the nNOS selective inhibitor N( $\omega)$-propyl-L-arginine (NPLA; $300 \mathrm{nmol} ; \mathrm{n}=7$ ), or saline were intradiscally injected as described before. NPLA (Tocris) was dissolved in sterile saline $(\mathrm{NaCl} 0.9 \%, \mathrm{w}: \mathrm{v})$ and freshly prepared. Analyzes of the degenerative changes in intervertebral discs were carried out by MRI and histological score at two days after nNOS blocking.

2.8 Part III: Intradiscal nNOS silencing through the nNOS siRNA. Seven animals were used to assess the role of NO from nNOS isoform in the induced disc degeneration through the nNOS siRNA. To evaluate the degenerative changes in the intervertebral discs transfected with siRNA or the control group the MRI analyze was conducted at 2 and 21 days after injection. The histological score was evaluated at 21 days after the siRNA injection. 
2.8.1 Synthetic siRNA preparation. The nNOS mRNA target sequence was determined by using the Biopredsi algorithm (21). The sequence used in this study is placed in exon 28 of the human nNOS complementary DNA sequence (NM_000620.2), 5'GCGAACGTACGAAGTGACCAA-3', nt 4898 - 4918. The synthetic siRNA display total nucleotide identity to this target sequence, which can be found in nNOS-splicing variants $\alpha, \beta$, or $\gamma$. It was synthesized as double-stranded RNA sequences with 21 nucleotides, and named siRNAnNOShum_4400 (Qiagen). The designed siRNA will establish Watson-Crick base pairs with a complementary sequence present in nNOS mRNA, thus guiding the RNA-induced silencing complex (RISC) to clive this target mRNA. We also used a commercial negative control siRNA (All stars®, Qiagen, Valencia, California, USA).

\subsubsection{In vitro study procedures}

2.8.2.1 Cell culture. To analyze the ability of siRNA described below to silence nNOS, we used four distinct cell lineages: SH-SY5Y (ATCC® CRL-2266 ${ }^{\mathrm{TM}}$ ), U-251 MG (Cell lines services CLS), U-87 MG (ATCC® HTB-14 ${ }^{\mathrm{TM}}$ ), and U-138 MG (ATCC® HTB$\left.16^{\mathrm{TM}}\right)$. Cells were maintained in DMEM/F12 medium supplemented with 1\% Glutamax (Gibco, NY, USA), 10\% heat-inactivated fetal bovine serum, $100 \mathrm{U} / \mathrm{mL}$ penicillin G, 100 $\mu \mathrm{g} / \mathrm{mL}$ streptomycin, and $250 \mathrm{ng} / \mathrm{mL}$ amphotericin B (Sigma Aldrish, Madrid, Spain). They were seeded into flasks and maintained at $37^{\circ} \mathrm{C}$ in a humidified atmosphere of $5 \%$ $\mathrm{CO} 2$ and $95 \%$ air.

2.8.2.2 Cell transfection. Transfections with siRNA were carried out with Lipofectamine (Lipofectamine 2000 Transfection Reagent, Invitrogen, Carlsbad, California, USA) and Opti-Men I (Invitrogen, Carlsbad, California, USA), according to the manufacturer's instructions. Cells received 150 pmol of siRNAnNOShum_4400, and the effects on nNOS mRNA content was determined at $24 \mathrm{~h}$ post-transfection.

2.8.2.3 Reverse transcription qPCR (RT-qPCR) in cell culture. Total RNA was extracted with a commercial kit (RNeasy ® Plus Mini Kit, Qiagen, Hilden, Germany), and quantified by fluorometry (Qubit®, Invitrogen, Carlsbad, California, USA). The purity was considered acceptable for RNA/protein ratios above 1.8. RNA integrity was analyzed by agarose gel electrophoresis. Synthesis of cDNA was performed from $500 \mathrm{ng}$ 
total RNA, by using random primers (SuperScript First-Strand Synthesis System for RTPCR, Invitrogen, Carlsbad, California, USA). We performed the RT-qPCR reaction in a 7500 Fast Real-Time PCR (Applied Biosystems, Carlsbad, California, USA). The forward and reverse primers for nNOS amplification were 5'GGTGGAGATCAATATCGCGGTT -3' and 5'-CCGGCAGCGGTACTCATTCT-3' (22). For the housekeeping gene, we used the GC-rich promoter binding protein 1 (GPBP1) primers 5'-TCACTTGAGGCAGAACACAGA-3' and 5'AGCACATGTTTCATCATTTTCAC-3' (23). Amplification products were detected via intercalation of the fluorescent dye SYBR Green. Briefly, the reaction mix contained 5.0 $\mu$ L Fast SYBR Green Master mix (Applied Biosystem, Carlsbad, California, USA), 2.0 $\mu \mathrm{L}$ of cDNA diluted 1:10, $0.4 \mu \mathrm{L}$ each sense and antisense primer (10 pmol/ $\mu \mathrm{L})$, and milli-Q pure water up to $10.0 \mu \mathrm{L}$. The polymerase chain reaction program included an initial denaturation at $95^{\circ} \mathrm{C}$ for $5 \mathrm{~min}$, followed by 40 cycles of amplification $\left(95^{\circ} \mathrm{C}\right.$ for $1 \mathrm{~min}, 60^{\circ} \mathrm{C}$ for $1 \mathrm{~min}$ ). Each run was carried out in triplicate, and the assay included negative reverse transcription (non template) controls. Delta delta $\mathrm{Ct}\left(2^{-\Delta \Delta \mathrm{Ct}}\right)$ relative quantification method was used to express the RNAi effects on nNOS message content (24).

\subsubsection{In vivo study procedures}

2.8.3 siRNA application. The nNOS siRNA injection was carried out using the transfection reagent Lipofectamine according to the manufacturer's instructions. Under general anesthesia, the siRNA against nNOS - siRNAnNOShum_4400 (150 pmol) or the control solution (RNAse free water plus Lipofectamine) were intradiscally injected.

2.9 Statistical analysis. MRI signal and nNOS mRNA expression (mean \pm SEM) were analyzed by one-way analysis of variance (ANOVA) followed by the Newman-Keuls post hoc test or multiple test $t$ analyses when appropriated. Temporal analyze on siRNA treated group was carried out by a general linear model of repeated measures. All data were expressed as the mean \pm SEM. Histological scores (median \pm SEM) were evaluated by the non-parametric Kruskal-Wallis test followed by the Mann-Whitney test. In all cases, the level of significance was set at $\mathrm{p}<0.05$. 


\section{Results}

3.1 Part I. nNOS detection in the intervertebral disc. The real time qPCR was used to evaluate nNOS mRNA expression in both intact and induced-degenerated discs. As seen in the Figure 1, nNOS mRNA expression was found in both the intact and degenerated discs of the rat coccygeal region. However, the real time qPCR suggests that NOS before lesion is quite low, practically absent. The degenerated disc showed an increase in the nNOS mRNA expression 5 hours post-lesion ( $\mathrm{p}<0.01$; $=3$; Figure 1). The nNOS mRNA expression remained increased at $24 \mathrm{~h}$ post-lesion although this difference did not reach statistical significance. Five days after the lesion procedure the nNOS mRNA was similar to the basal condition.

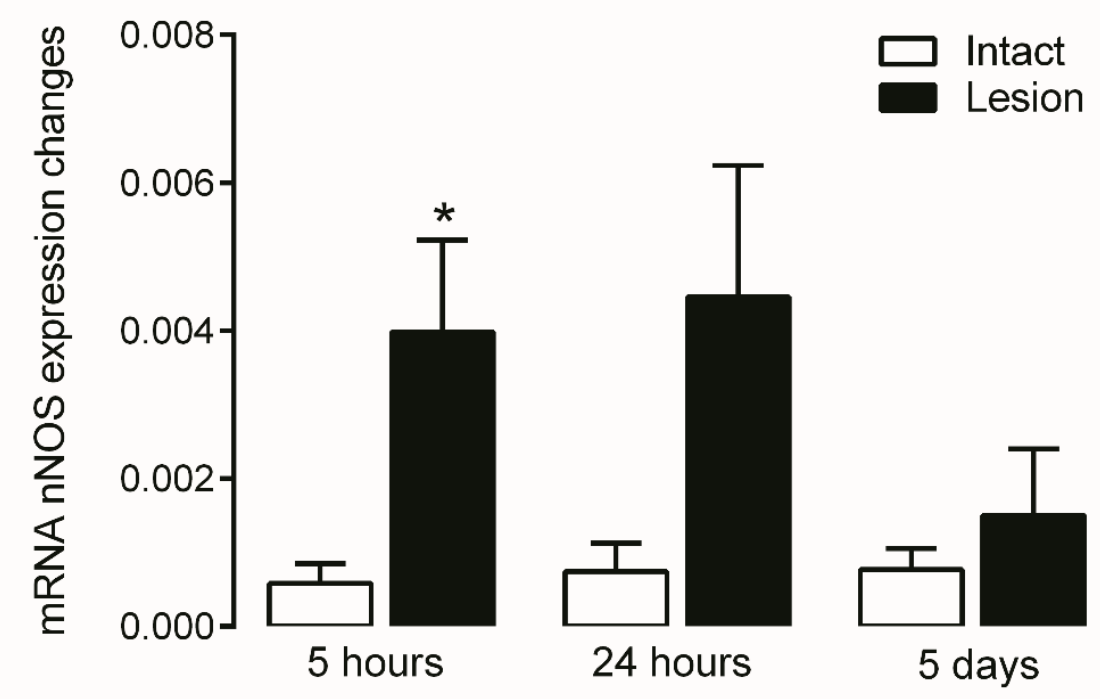

Figure 1. Changes in nNOS mRNA expression in the intervertebral disc at $5 \mathrm{~h}, 24 \mathrm{~h}$ or 5 days post-lesion. The lesion procedure induced a strong increase in nNOS mRNA expression. Data normalized by GAPDH. $* * \mathrm{p}<0.01$ compared to Intact group (one-way ANOVA; mean \pm SEM).

Accordingly, positive cells expressing nNOS protein were found in annulus fibrosus of both intact and induced-degenerated disc (Figure 2A and B). To guarantee the specificity of the nNOS positive labeling we tested two different antibodies with different concentrations (see Methods). Also, we include a sagittal section of spinal cord neurons as an "internal" positive control for the specificity of the nNOS positive immunoreaction. The absence of immunopositive cell signaling was confirmed with no primary antibody incubation. 

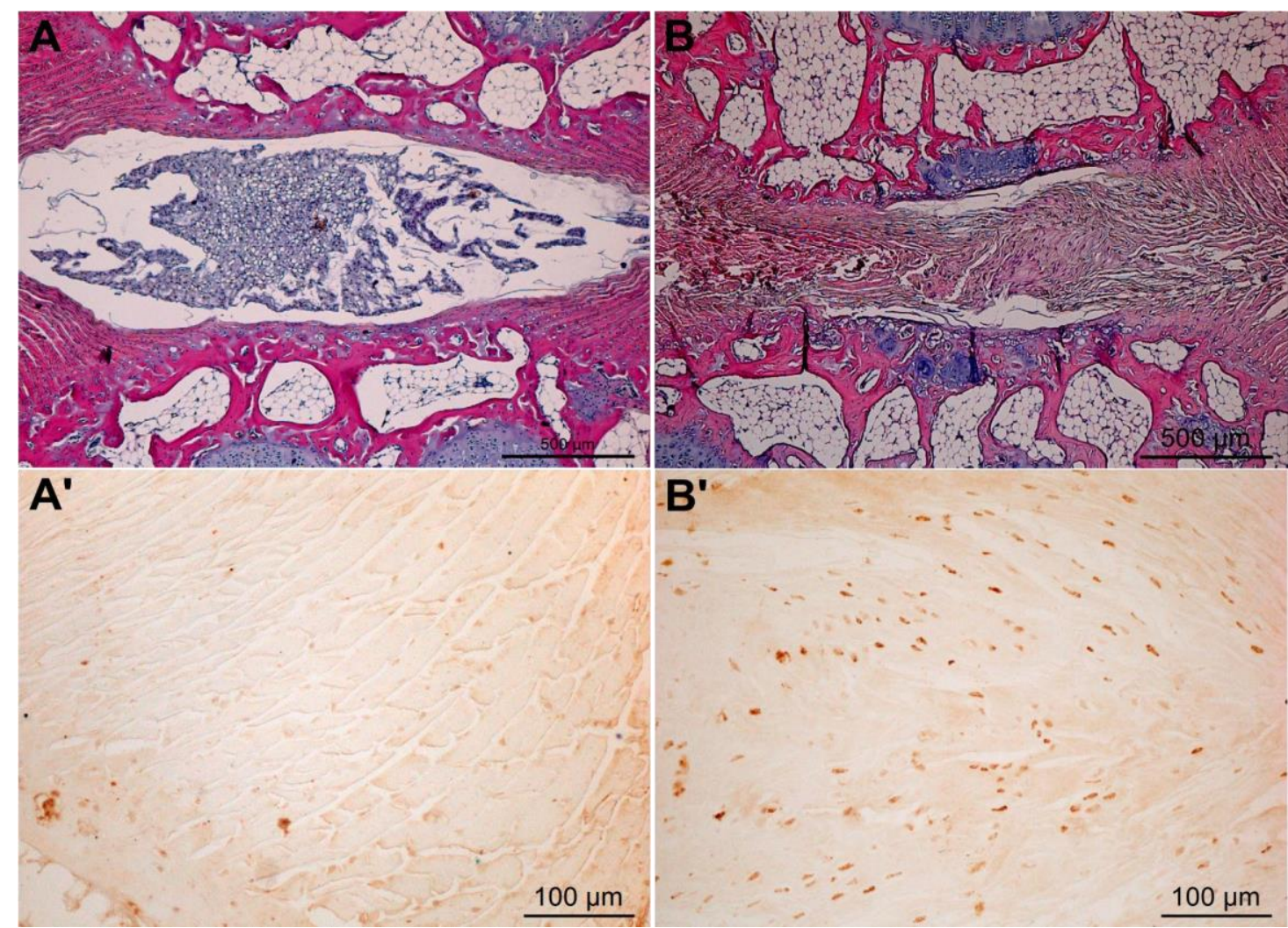

Figure 2A. Representative sections prepared with $\mathrm{H} \& \mathrm{E}$ staining (A and $\mathrm{B}$; 5X) and nNOS immunopositivity detected in the coccygeal intervertebral disc cells of annulus fibrosus (A' and B'; 10X). (A) Intact disc showing nucleus pulposus (NP) comprising at least one-half of the disc area in the sagittal sections and an intact annulus fibrosus (AF), with a clearly border between AF and NP. (B) Injured disc (21-gauge needle punctured) 2 days after lesion. The NP area is decreased with complete obliteration of its cavity with fibrous material, and with an irregular contour. In the inferior panel the nNOS immunohistochemical representative photomicrographs of AF of intact ( $\mathrm{A}^{\prime}$ - near to the endplate) and injured $\left(\mathrm{B}^{\prime}-\right.$ middle of the $\left.\mathrm{AF}\right)$ discs. The AF regions showed in $\mathrm{A}^{\prime}$ and $\mathrm{B}^{\prime}$ are represented in the superior panel. The nNOS immunoreactivity (anti-nNOS - rabbit; 1:250, Santa Cruz Biotechnology) was revealed with DAB as the chromogen. nNOS immuno-positive cells are stained in brown. 

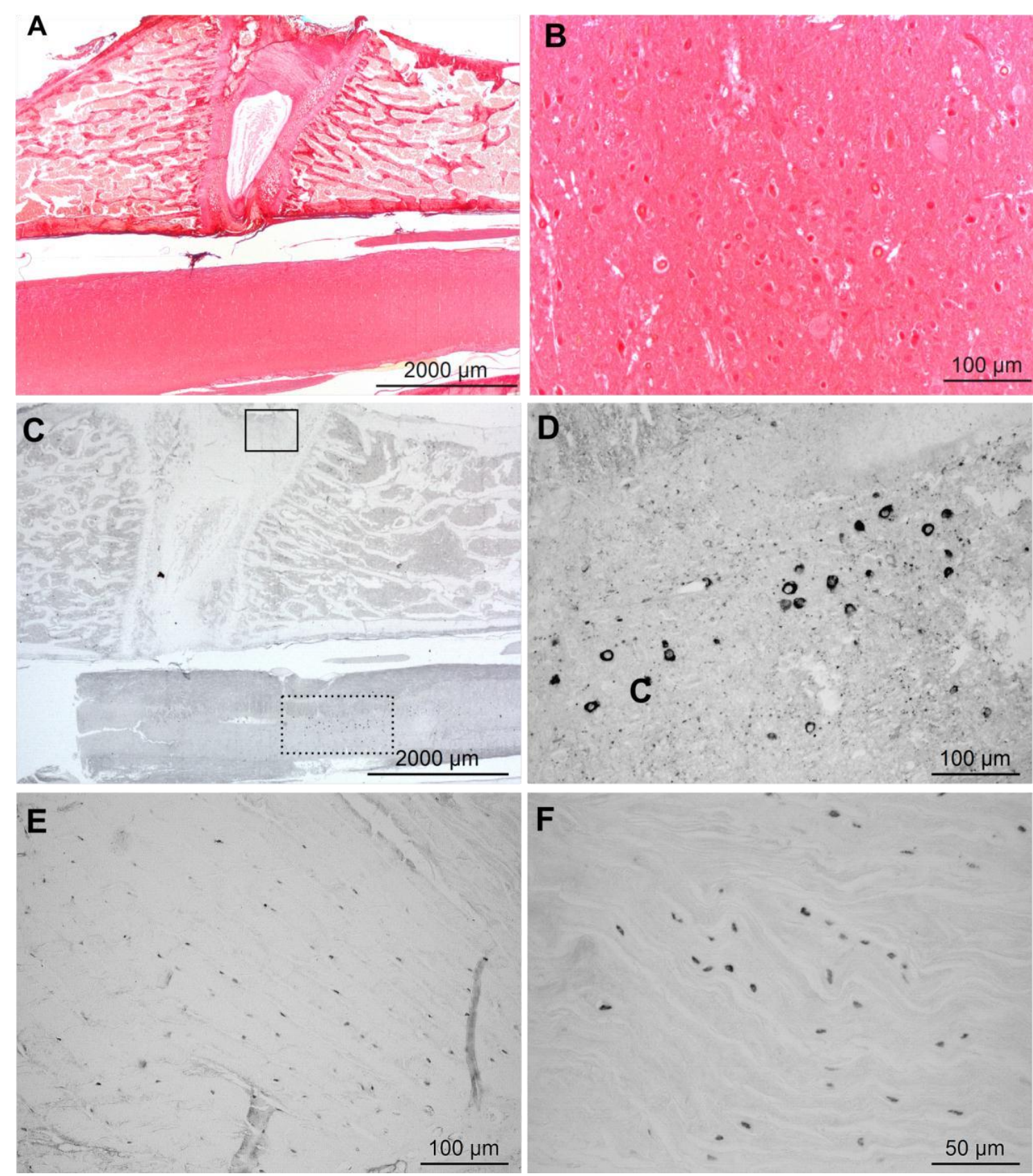

Figure 2B. Representative histological sections prepared with picrosirius red staining (A and B) and nNOS immunoreactivity in the lumbar intervertebral disc and spinal cord (C-F). A and C. Sagittal sections comprising both intact intervertebral disc and spinal cord, as a positive control of the nNOS immunoreactivity (1.6X). In the spinal cord, neurons stained by either picrosirius (A) or nNOS immunohistochemistry (C) are highlighted in the dotted frames. B and D. Spinal cord neurons stained by picrosirius (B) or nNOS immunohistochemistry (D;10X). E. Annulus fibrosus of the intact disc highlighted in the continuous frame of panel $\mathrm{C}$ showed in the high augmentation (10X). F. Nucleus pulposus of the intact disc highlighted in the continuous frame of panel $\mathrm{C}$ showed in the high augmentation (10X). The nNOS immunoreactivity (anti-nNOS - sheep; 1:4000, gift of P. Emson, Cambridge, UK) was revealed with DAB plus nickel as the chromogen (C-F). nNOS immuno-positive cells are stained in dark gray. 
3.2 Part II. Intradiscal pharmacological inhibition of nNOS. To evaluate the role of NO from nNOS isoform in the induced disc degeneration, we performed the intradiscal injection of the selective nNOS inhibitor, NPLA. The MRI signal of both lesioned discs, which received vehicle (Co8-9; sterile saline, $2 \mu 1$ ), or which received NPLA (Co6-7; $300 \mathrm{nmol}, 2 \mu \mathrm{l}$ ) was found significantly decreased at 2 days after the lesion procedure when compared to the intact group $(\mathrm{Co} 7-8 ;(F(2,18)=27.83 ; \mathrm{p}<0.001)$, Figure 3A). However, treatment with NPLA, immediately after the lesion, produced a significant increase in the MRI signal intensity when compared to the lesioned discs which received vehicle $(\mathrm{p}<0.05)$. The lesioned discs, which received vehicle $(\mathrm{Co8}-9)$, showed a $55.56 \%$ of reduction in the MRI signal intensity. The reduction in the signal intensity of lesioned discs, which received NPLA, was $38.89 \%$.

In addition, the lesioned discs, which received vehicle, showed a significant worse histological score when compared to the intact discs either the annulus fibrosus $(\mathrm{H} 2=10.25, \mathrm{p}=0.006)$ and nucleus pulposus $((\mathrm{H} 2=10.15, \mathrm{p}=0.006)$; Figure 3B $)$. NPLA mitigated the effect of intervertebral disc injury on the histological score only at annulus fibrosus. Lesioned discs treated with NPLA presented no statistical difference to the intact control group regards to the annulus fibrosus histological grading scores (Figure 3B).

A

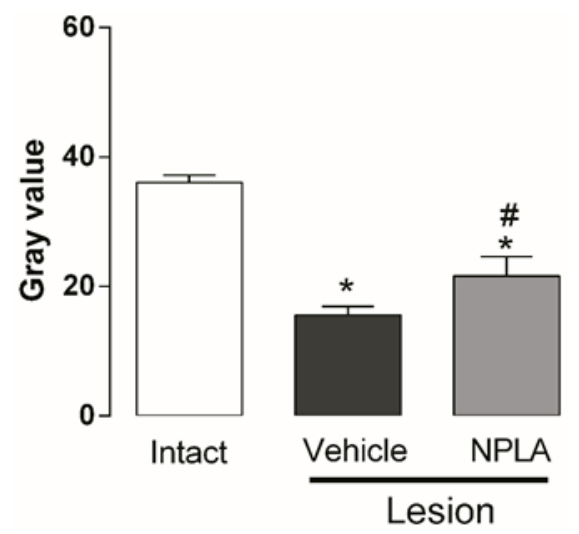

B

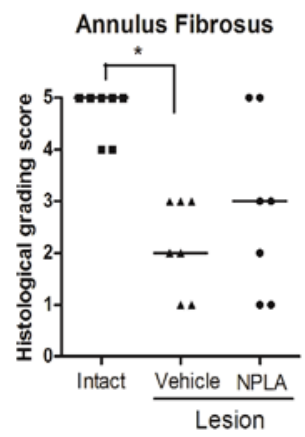

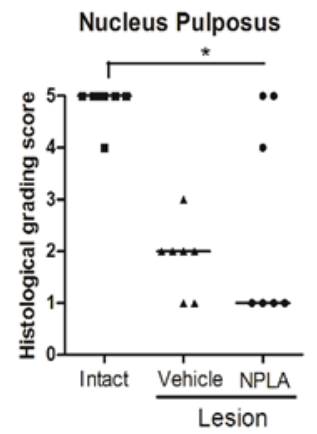

Figure 3. Effects of NPLA on MRI signal (T2 sequences) and in the histological analyses of intervertebral discs at 2 days after lesion. The lesioned discs injected with vehicle $(2 \mu \mathrm{l})$ presented a significant decrease of the MRI signal (A) and in the histological score (B) when compared to the intact segments. The injection of the preferential nNOS inhibitor NPLA ( $300 \mathrm{nmol})$ mitigates the lesion effects in the MRI signal intensity and in the histological score. (A) *p<0.05 - MRI found in vehicle and NPLA-injected discs compared to the intact discs; \#p<0.05 - lesioned discs treated with NPLA compared to those injected with vehicle; Oneway ANOVA followed by Newman-Keuls post hoc test; n=7. (B) *p $<0.05$ - Differences in histological grading scores, Kruskal-Wallis followed by Mann-Whitney, (median \pm SEM; $n=7$ ). 


\subsection{Part III. Intradiscal nNOS silencing through the nNOS siRNA}

3.3.1 In vitro study procedures. The down-regulating effects of siRNA on nNOS were confirmed in culture cells. The structure siRNAnNOShum_4400 reduced the nNOS mRNA content at $24 \mathrm{~h}$ post-transfection in all four lineages in test, as determined by RTqPCR (Table 1). Knocking down effects on nNOS message varied according to the cell lineage in test. The highest silencing effects occurred for cell lineages U-87 MG (0.55 fold), followed by U-251 MG. SH-SY5Y and U-138 MG cells showed a relatively lower reduction in nNOS mRNA content ( 0.66 fold) after transfection.

3.3.2 In vivo study procedures. To evaluate the role of NO from nNOS isoform in the induced disc degeneration we performed the intradiscal nNOS siRNA transfection. The degenerative changes were examined through the MRI analyze at 2 and 21 days post transfection, and the histological score at 21 days.

The MRI signal of the lesioned discs which received vehicle (Co8-9; transfection solution Lipofectamine 2000 and RNAse free water, $2 \mu 1$ ) was found significantly decreased either at 2 and 21 days after the lesion procedure when compared to the intact discs $(\mathrm{Co} 7-8 ;(\mathrm{F}(4,44)=10.27, \mathrm{p}<0.0001)$, Figure 4A). Treatment with 150pmol of nNOS siRNA immediately after lesion did not produce significant differences in the MRI signal intensity compared to the lesioned discs treated with vehicle either at 2 or 21 days after lesion (n=9; Figure 4A).

A

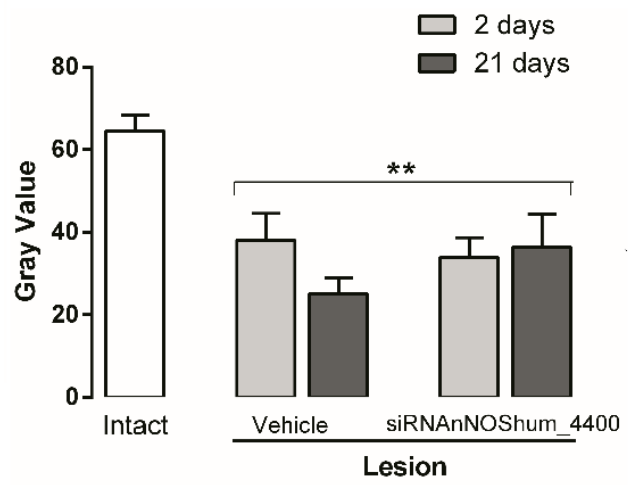

B
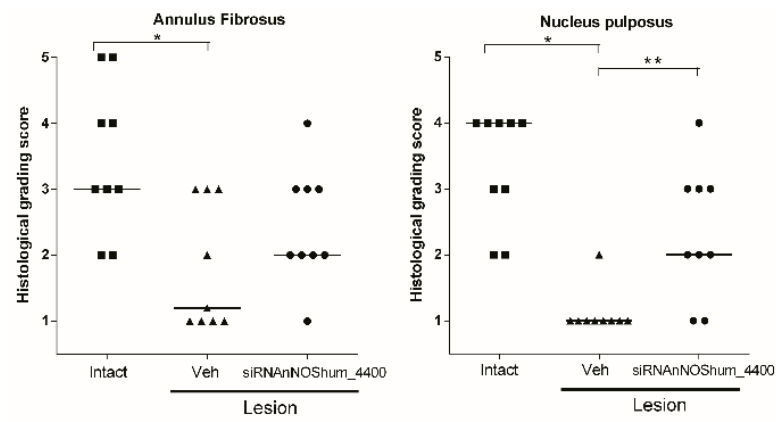

Figure 4. Effects of $150 \mathrm{pmol}$ of siRNAnNOShum_4400 in the (A) MRI (T2 sequences) of intervertebral discs at 2 and 21 days after lesion and (B) in the histological scores. (A) The lesion procedure caused significant decrease in the MRI signal intensity of either vehicle and nNOS siRNA injected discs compared to the intact discs. The injection of $150 \mathrm{pmol}$ of nNOS siRNA immediately after lesion appears to mitigate the degenerative progress at 21 days after lesion (mean of vehicle injected discs $=25.11$ and mean of 
siRNAnNOShum_4400 injected discs $=36.44)$. $* * \mathrm{p}<0.05$ compared to the intact discs, repeated measures ANOVA followed by Newman-Keuls post hoc test; $n=9$. (B) The lesioned discs injected with vehicle $(2 \mu \mathrm{l})$ showed significant decrease in the histologic scores compared to the intact discs scores. Treatment with $150 \mathrm{pmol}$ of nNOS siRNA immediately after lesion improved the histological scores of nucleus pulposus at 21 days post lesion, compared to those of the vehicle-injected discs. ${ }^{*} \mathrm{p}<0.05$; Kruskal-Wallis followed by Mann-Whitney, (median \pm SEM; $n=9$ ).

Interestingly, the lesioned group (vehicle) presented a worsening MRI signal at 21 days after lesion compared to the MRI signal at 2 days after lesion. Contrasting, the nNOS siRNA injected discs did not show increased loss of the MRI signal intensity at 21 days after lesion compared with the first time post-lesion analyzed (two days). These results suggest that probably there was a progress in the disc-degenerative process in the lesioned vehicle-treated discs. Representative MRI images collected for analysis of tissue hydration of siRNAnNOShum_4400 injected disc are represented at Figure 5.
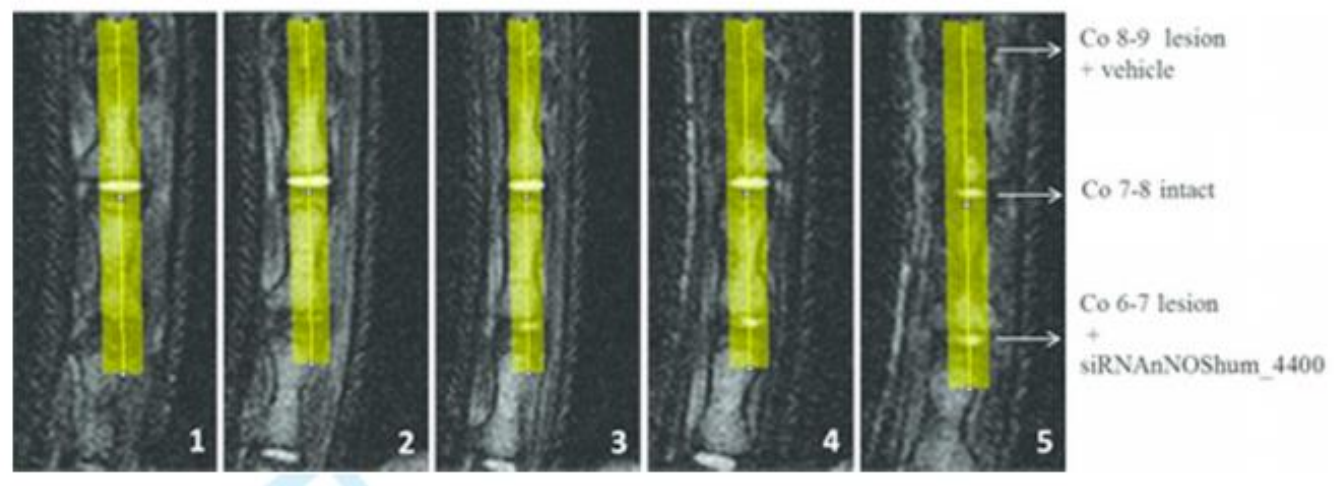

Figure 5. T2-weighted MRI from siRNAnNOShum_4400 injected disc. The Image J® software was used for analyses. The yellow tracing over the image represents the area analyzed from 5 sequential sagittal images of intervertebral discs. MRI data are presented as a gray scale value which corresponding to the MRI pixel intensity.

MRI data were corroborated by the histological analyses. The lesion procedure caused a significant decrease in the scores of the annulus fibrosus $(\mathrm{H} 2=8.31, \mathrm{p}=0.016)$ and nucleus pulposus in the mock-treated group $(\mathrm{H} 2=16.30, \mathrm{p}<0.001$, Figure 4B). Regards to the group treated with 150pmol of siRNAnNOShum_4400 after lesion, the scores of the annulus fibrosus and nucleus pulposus were not different to those found in intact discs. Indeed, siRNA treated group showed a significant higher histological scores 
in the nucleus pulposus in comparison to the group treated with vehicle (Mann-Whitney; $\mathrm{p}<0.050$; Figure 4B).

\section{Discussion}

We demonstrate the presence of the nNOS isoform, mRNA and protein, in both intact and induced-degenerated (needle punctured) rat coccygeal intervertebral discs. Our study revealed that nNOS mRNA was overexpressed in the onset of the induced disc degenerative process (mainly at 5 hours post lesion). The acute inhibition of intradiscal NO synthesis through the NPLA, a highly selective and potent nNOS inhibitor (25) induced a modest but significant improvement in the intervertebral disc revealed through the MRI analyses. In the annulus fibrosus, but not in the nucleus pulposus, NPLA treatment was able to mitigate the histological injury induced by the needle puncture. The reason for the difference in the NPLA effects in the annulus fibrosus and nucleus pulposus most likely are related to the different histology and physiology of these components. We have previously reported similar results with another pharmacological approach (26). The siRNA to silencing nNOS expression during the disc degenerative process suggested a minor modification in the disc health parameters detected through both MRI and histological analyses at 21 days after siRNA injection. The absence of siRNA-induced effects at 2 days after lesion was unexpected considering that in vitro siRNA induced a post-transcriptional silencing on nNOS mRNA content at $24 \mathrm{~h}$ post-transfection, and acute pharmacological inhibition of nNOS altered in some degree the discal degenerative process. The intervertebral disc represents the largest avascular structure in the body; as well, intervertebral discs are encapsulated and immune-privileged sites (27). The absence of blood supply to the intervertebral disc may limit the effectiveness of self-repair strategies (28). Therefore, the intervertebral disc is classified as a suitable target organ for local and direct therapy (27).

We demonstrated the presence of nNOS in the intervertebral disc through the mRNA and immunoreactivity protein. These techniques are largely used to recognize the specific NOS isoform in different organs and tissues (29). The constitutive isoforms of NOS are not localized only in the tissues from which they were originally identified. The nNOS isoform is the predominant source of NO in neurons, but is also present in the skeletal, cardiac and smooth muscles where NO controls blood flow and muscle contractility (30-32). Pharmacological NOS inhibitors represent an essential tool to 
provide the biological roles of NO (33). The NPLA was described with a considerable degree of selectivity in favor of nNOS (25). Interestingly, the potency of inhibition of nNOS by NPLA is 3158 times that of iNOS (25). In this context, inflammatory cytokines or MMPs, usually related to iNOS, are not inhibit by NPLA or nNOS-target siRNA, which helps to explain the slight improvement in the disc degeneration process described here. Despite the serial progressive changes of several other biochemical components which well characterized intervertebral disc degeneration (1).

The inappropriate release of NO has been linked to several pathologies, including the intervertebral disc degeneration. In most studies, the NO increase synthesized from the iNOS isoform had been suggested as part of the disc degenerative cascade $(2-5,34)$. It has been suggested that the NO increase might have a deleterious role in the synthesis and maintenance of important disc constituents as proteoglycan, collagen type II and chondrocytes $(2,11,35,36)$. An additional consequence of the increased NO levels is the stimulated production of the metalloproteinases (MMPs) $(12,13)$. Synthesized by disc cells, MMPs are crucial in disc degeneration by initiating matrix degradation and by promotion of catabolic processes $(37,38)$. Furthermore, MMP-2 has been implicated in the induction of neovascularization during disc degeneration (39).

Although the exact cellular origin of NO in the intervertebral disc is unknown, the NO produced by constitutive NOS may be biologically important. Previously, Pitsillides and co-workers (40) described that in bone the NO production and expression of both iNOS and nNOS isoforms are increased by mechanical stress. We found in the degenerated discs a robust increase of nNOS mRNA detection and $\mathrm{nNOS}$ immunopositivity, despite the smaller extent of these findings in the intact disc. As mentioned before, the neurogenesis and the angiogenesis are tissue changes associated with advanced disc degeneration process (1). Both events may contribute to the increase of the expression of constitutive NOS isoforms. In view of the previously described NO role in the intervertebral disc degeneration, a synergistic effect between constitutive and inducible NOS isoforms inhibitors could be considered.

Although the induced-degenerative model does not truly reflect the course of human disc degeneration, similar histological and biomechanical changes exist between rat and human disc degenerative process. Clinical studies may provide further support for the possibility of $\mathrm{NO} / \mathrm{nNOS}$ alteration in the degenerative process. 
In conclusion, our study revealed the presence of constitutive nNOS in the intervertebral disc and its overregulation during the disc degenerative cascade. Since the regeneration process in the intervertebral disc appears unlikely this knowledge may start address to the potential anti-degenerative effects of intradiscal NOS inhibition.

Acknowledgements. We would like to thank Célia Ap. da Silva for the technical support. This research was supported by CAPES/PNPD, Brazil. The equipment and drugs used in this work were acquired from FAPESP, CNPq, and CAPES, Brazil. The funders had no role in study design, data collection and analysis, decision to publish, or preparation of the manuscript.

Competing interests. The authors have declared that no competing interests exist.

\section{References}

(1) Freemont AJ. The cellular pathobiology of the degenerate intervertebral disc and discogenic back pain. Rheumatology (Oxford) (2009) 48: 5-10.

(2) Furusawa N, Baba H, Miyoshi N, Maezawa Y, Uchida K, Kokubo Y, Fukuda M. Herniation of cervical intervertebral disc: immunohistochemical examination and measurement of nitric oxide production. Spine (Phila Pa 1976) (2001) 26: 1110-1116.

(3) Liu GZ, Ishihara H, Osada R, Kimura T, Tsuji H. Nitric oxide mediates the change of proteoglycan synthesis in the human lumbar intervertebral disc in response to hydrostatic pressure. Spine (Phila Pa 1976) (2001) 26: 134-141.

(4) Kang JD, Georgescu HI, McIntyre-Larkin L, Stefanovic-Racic M, Evans CH. Herniated cervical intervertebral discs spontaneously produce matrix metalloproteinases. nitric oxide, interleukin-6, and prostaglandin E2, Spine (Phila Pa 1976) (1995) 20: 23732378.

(5) Denda H, Kimura S, Yamazaki A, Hosaka N, Takano Y, Imura K, Yajiri Y, Endo N. Clinical significance of cerebrospinal fluid nitric oxide concentrations in degenerative cervical and lumbar diseases. Eur Spine J (2011) 20: 604-611. 
(6) Lamas S, Marsden PA, Li GK, Tempst P, Michel T. Endothelial nitric oxide synthase: molecular cloning and characterization of a distinct constitutive enzyme isoform. Proc. Natl. Acad. Sci. U.S.A. (1992) 89: 6348-6352.

(7) Mungrue IN, Bredt DS Stewart DJ, Husain M. From molecules to mammals: what's NOS got to do with it? Acta Physiol. Scand. (2003) 179: 123-135.

(8) Garthwaite J, Boulton CL. Nitric oxide signaling in the central nervous system. Annu. Rev. Physiol (1995) 57: 683-706.

(9) Blanco FJ, Lotz M. IL-1-induced nitric oxide inhibits chondrocyte proliferation via PGE2. Exp Cell Res 218 (1995) 319-325.

(10) Hauselmann HJ, Oppliger L, Michel BA, Stefanovic-Racic M, Evans CH. Nitric oxide and proteoglycan biosynthesis by human articular chondrocytes in alginate culture. FEBS Lett (1994) 352: 361-364.

(11) Kohyama K., Saura R, Doita M, Mizuno K. Intervertebral disc cell apoptosis by nitric oxide: biological understanding of intervertebral disc degeneration. The Kobe journal of medical sciences (2000) 46: 283-285.

(12) Murrell GA, Jang D, Williams RJ. Nitric oxide activates metalloprotease enzymes in articular cartilage. Biochem Biophys Res Commun (1995) 206: 15-21.

(13) Sakurai H, Kohsaka H, Liu MF, Higashiyama H, Hirata Y, Kanno K, Saito I, Miyasaka N, Nitric oxide production and inducible nitric oxide synthase expression in inflammatory arthritides. J Clin Invest (1995) 96: 2357-2363.

(14) Sasaki K, Hattori T, Fujisawa T, Takahashi K, Inoue H, Takigawa M. Nitric oxide mediates interleukin-1-induced gene expression of matrix metalloproteinases and basic fibroblast growth factor in cultured rabbit articular chondrocytes. J Biochem (1998) 123: 431-439.

(15) Rannou F, Richette P, Benallaoua M, François M, Genries V, Korwin-Zmijowska C, Revel M, Corvol M., Poiraudeau S. Cyclic tensile stretch modulates proteoglycan production by intervertebral disc annulus fibrosus cells through production of nitrite oxide. J Cell Biochem (2003) 90: 148-57.

(16) Han B, Zhu K, Li FC, Xiao YX, Feng J, Shi ZL, Lin M, Wang J, Chen QX. A simple disc degeneration model induced by percutaneous needle puncture in the rat tail. Spine (Phila Pa 1976) (2008) 33: 1925-1934.

(17) Mao H, Chen Q, Han B, Li F, Feng J, Shi Z, Lin M, Wang J. The effect of injection volume on disc degeneration in a rat tail model. Spine (2011) 16: 1062-1069. 
(18) Schiebler ML, Camerino VJ, Fallon MD, Zlatkin MB, Grenier N, Kressel HY. In vivo and ex vivo magnetic resonance imaging evaluation of early disc degeneration with histopathologic correlation. Spine (1991) 16: 635-640.

(19) Norcross JP, Lester GE, Weinhold P, Dahners LE. An in vivo model of degenerative disc disease. J Orthop Res (2003) 21: 183-188.

(20) Issy AC, Castania V, Castania M, Salmon CE, Nogueira-Barbosa MH, Del Bel E, Defino HL. Experimental model of intervertebral disc degeneration by needle puncture in Wistar rats. Braz J Med Biol Res (2013) 46: 235-244.

(21) Huesken D, Lange J, Mickanin C, Weiler J, Asselbergs F, Warner J, Meloon B, Engel S, Rosenberg A, Cohen D, Labow M, Reinhardt M, Natt F, Hall J. Design of a genomewide siRNA library using an artificial neural network. Nature biotechnology (2005) 23: 995-1001.

(22) Dotsch J, Harmjanz A, Christiansen H, Hanze J, Lampert F, Rascher W. Gene expression of neuronal nitric oxide synthase and adrenomedullin in human neuroblastoma using real-time PCR. International journal of cancer (2000) 8: 172-175.

(23) Kwon MJ, Oh E, Lee S, Roh MR, Kim SE, Lee Y, Choi YL, In YH, Park T, Koh SS, Shin YK. Identification of novel reference genes using multiplatform expression data and their validation for quantitative gene expression analysis, PLoS One (2009) 4: 61-62. (24) Livak KJ, Schmittgen TD. Analysis of relative gene expression data using real-time quantitative PCR and the 2(-Delta Delta C(T)) Method. Methods (2001) 25: 402-408.

(25) Zhang HQ, Fast W, Marletta MA, Martasek P, Silverman RB. Potent and selective inhibition of neuronal nitric oxide synthase by $\mathrm{N}$ omega-propyl-L-arginine. J Med Chem (1997) 40: 3869-3870.

(26) Silveira JW, Issy AC, Castania VA, Salmon CE, Nogueira-Barbosa MH, Guimarães FS, Defino HL, Del Bel E. Protective effects of cannabidiol on lesion-induced intervertebral disc degeneration. PLoS One (2014) 9: 1-13.

(27) Nishida K, Suzuki T, Kakutani K, Yurube T, Maeno K, Kurosaka M, Doita M. Gene therapy approach for disc degeneration and associated spinal disorders. Eur Spine J Suppl 4 (2008) 17: 459-466.

(28) Burnett JC Rossi JJ. RNA-based therapeutics: current progress and future prospects. Chem Biol (2012) 19: 60-71.

(29) Mattson DL, Wu F. Nitric oxide synthase activity and isoforms in rat renal vasculature. Hypertension (2000) 35: 337-341. 
(30) Santizo R, Baughman VL, Pelligrino DA. Relative contributions from neuronal and endothelial nitric oxide synthases to regional cerebral blood flow changes during forebrain ischemia in rats. Neuroreport (2000) 11: 1549-1553.

(31) Stamler JS, Meissner G. Physiology of nitric oxide in skeletal muscle. Physiol Rev (2001) 81: 209-237.

(32) Xu KY, Huso DL, Dawson TM, Bredt DS, Becker LC. Nitric oxide synthase in cardiac sarcoplasmic reticulum. Proc Natl Acad Sci U S A (1999) 96: 657-662.

(33) Moore PK, Handy RL. Selective inhibitors of neuronal nitric oxide synthasis (NOS). Is NOS really good for the nervous system? Trends Pharmacol Sci (1997) 18: 204-211.

(34) Kang JD, Stefanovic-Racic M, McIntyre LA, Georgescu HI, Evans CH. Toward a biochemical understanding of human intervertebral disc degeneration and herniation. Contributions of nitric oxide, interleukins, prostaglandin E2, and matrix metalloproteinases. Spine (1997) 22: 1065-1073.

(35) Van de Loo FA, Arntz OJ, Van den Berg WB. Effect of interleukin 1 and leukaemia inhibitory factor on chondrocyte metabolism in articular cartilage from normal and interleukin-6-deficient mice: role of nitric oxide and IL-6 in the suppression of proteoglycan synthesis, Cytokine (1997) 9: 453-462.

(36) Blanco FJ, Geng Y, Lotz M. Differentiation-dependent effects of IL-1 and TGF-beta on human articular chondrocyte proliferation are related to inducible nitric oxide synthase expression. J Immunol (1995) 154: 4018-4026.

(37) Grang L, Gaudin P, Trocme C, Phelip X, Morel F, Juvin R. Intervertebral disk degeneration and herniation: the role of metalloproteinases and cytokines. Joint Bone Spine (2001) 68: 547-553.

(38) Melrose J, Shu C, Young C, Ho R, Smith MM, Young AA, Smith SS, Gooden B, Dart A, Podadera J, Appleyard RC, Little CB. Mechanical destabilization induced by controlled annular incision of the intervertebral disc dysregulates metalloproteinase expression and induces disc degeneration. Spine (2012) 37: 18-25.

(39) Carreon LY, Ito T, Yamada M, Uchiyama S, Takahashi HE. Neovascularization induced by annulus and its inhibition by cartilage endplate. Its role in disc absorption. Spine (1997) 22: 1429-1434.

(40) Pitsillides AA, Rawlinson SC, Suswillo RF, Bourrin S, Zaman G, Lanyon LE. Mechanical strain-induced NO production by bone cells: a possible role in adaptive bone (re)modeling? FASEB J (1995) 9: 1614-1622. 
Anexo 4 - E-book: Biologia molecular - Fundamentos e Técnicas básicas

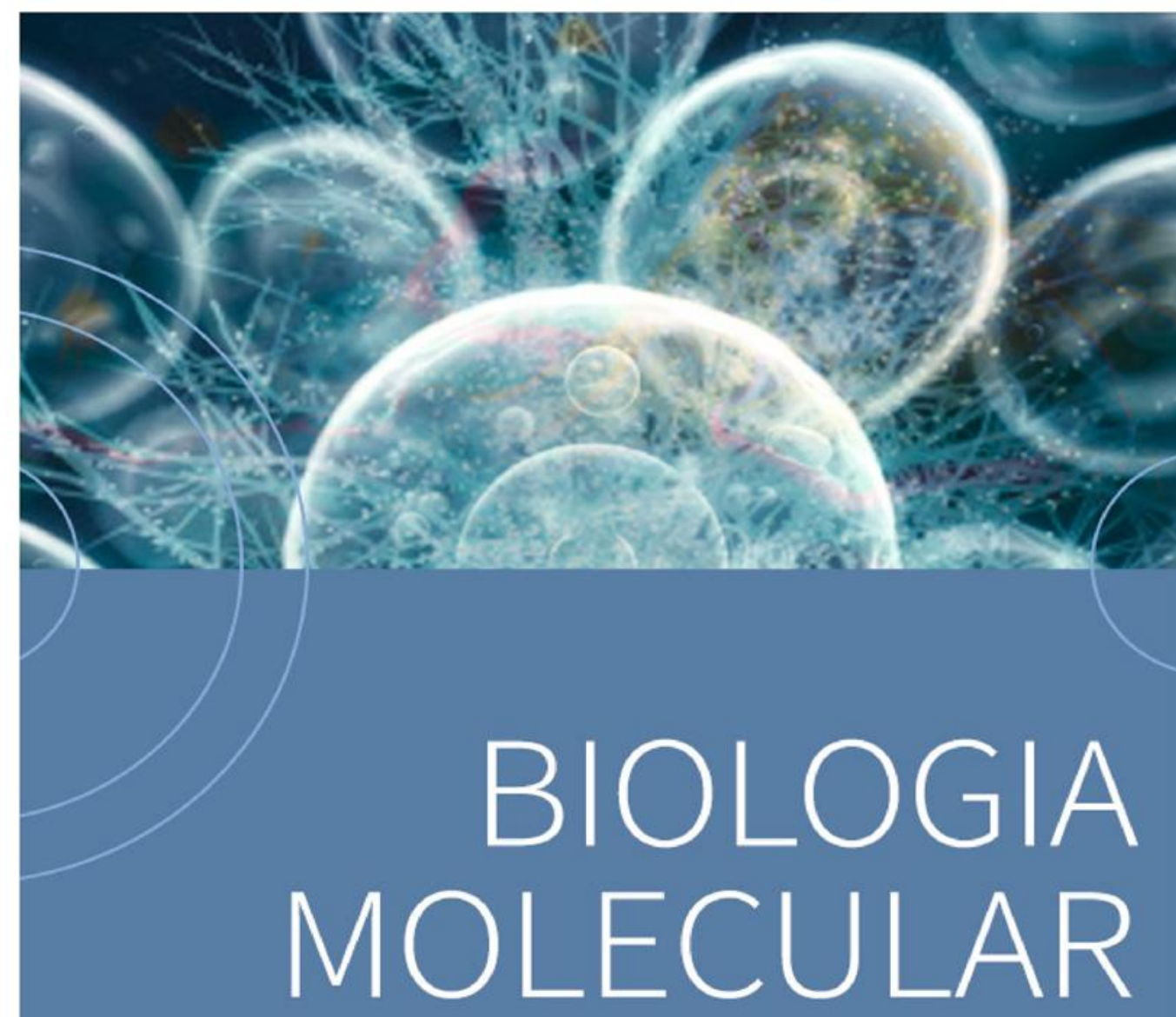

Fundamentos \& técnicas básicas RICARDO TITZE-DE-ALMEIDA 


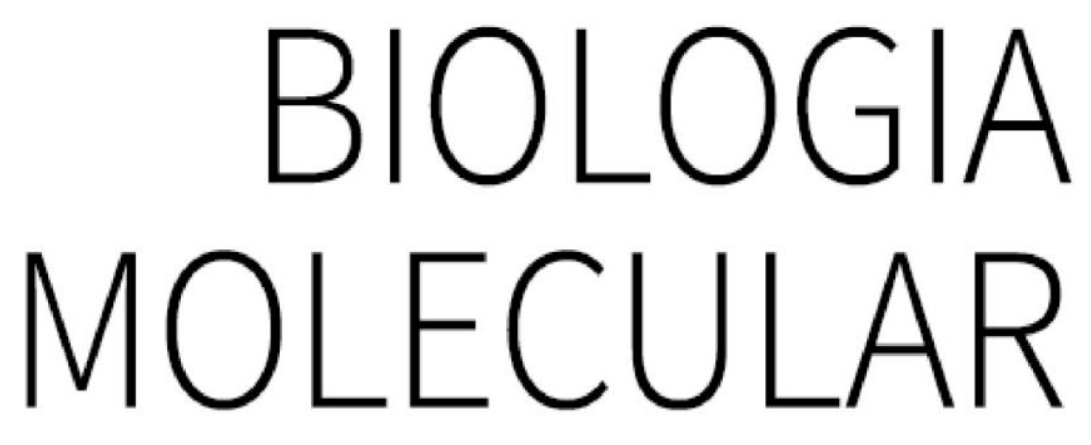

Fundamentos \& técnicas básicas

RICARDO TITZE-DE-ALMEIDA 


\section{(c) 2014, Ricardo Titze-de-Almeida}

Todos os direitos reservados e protegidos pela Lei no 9.610, de 19/02/1998.

Nenhuma parte deste eBook, sem autorização prévia por escrito do autor, poderá ser reproduzida ou transmitida sejam quais forem os meios empregados: eletrônicos, mecânicos, fotográficos, gravação ou quaisquer outros.

Editoração Eletrônica e versão eBook: Nextmidia Soluções Interativas.

\section{ISBN 978-85-917405-0-5}

0 autor não assume qualquer responsabilidade por eventuais danos ou perdas a pessoas ou bens, originados do uso desta publicação.

Dados Internacionais de Catalogação na Publicação (CIP)

\begin{tabular}{|c|c|}
\hline $\mathrm{T} 617 \mathrm{~b}$ & $\begin{array}{l}\text { Titze-de-Almeida, Ricardo } \\
\text { Biologia molecular : fundamentos \& } \\
\text { técnicas básicas [1ivro eletrônico] / Ricardo } \\
\text { Titze-de-Almeida. -- Brasilia : } 2014 \text {. } \\
\text { 2.454 Kb ; ePuB. } \\
\text { Bibliografia. } \\
\text { ISBN } 978-85-917405-0-5 \\
\text { 1. Biologia Molecular. 2. Ciência da vida. } \\
\text { I. Titulo. } \\
\text { CDD-500.570 }\end{array}$ \\
\hline
\end{tabular}

Indices para catálogo sistemático:

1. Ciência. 2. Ciência da vida; biologia. 500.570 
CAPÍTULO 2 CULTIVO CELULAR

Fernando Francisco Borges Resende

Cultivo celular é o processo pelo qual as células, sejam procarióticas ou eucarióticas, são cultivadas in vitro em condições controladas. Na prática, o termo "cultura de células" é geralmente usado em referência aos cultivos celulares eucariontes multicelulares isolados, especialmente de células animais.

\section{HISTÓRICO}

O princípio de toda a técnica de cultivo celular tem origem nos estudos do fisiologista inglês Sydney Ringer, desenvolvido em meados do século XIX. Ali foi formulada a solução salina - conhecida até hoje como solução de Ringer, à base de cloreto de sódio, potássio, cálcio e magnésio -, na qual foi mantido o coração de um animal batendo fora do corpo durante algum tempo. Em 1885, Wilhelm Roux removeu parte do tecido oriundo de embrião de galinha e o manteve vivo por vários dias em cultura, utilizando para tal uma solução salina morna, estabelecendo assim o princípio da cultura tecidual. Posteriormente, Ross Granville Harrison estabeleceu a metodologia de cultura de tecidos na Escola de Medicina da Universidade Johns Hopkins e depois na Universidade de Yale, trabalho publicado em uma série de artigos entre 1908 e 1910.

\section{ASPECTOS GERAIS SOBRE CULTIVO CELULAR}

O termo cultivo tecidual refere-se à cultura de um tecido qualquer, fora de seu organismo original. Por outro lado, cultivo celular está relacionado à manutenção in vitro de células individualizadas ou desagregadas de um tecido, sob condições controladas artificialmente. A cultura inicial, proveniente diretamente de um indivíduo, chama-se cultura primária; quando as células são transferidas de um frasco de cultivo a outro, temos o processo conhecido como passagem. Após algumas passagens esse cultivo primário torna-se, então, uma linhagem celular. As linhagens celulares podem ser classificadas como linhagens contínuas, quando as células possuem capacidade "ilimitada" de expansão, ou linhagens celulares finitas, quando as células cultivadas tem determin- 
ada vida útil, entrando em senescência após algumas passagens. Para torna-se contínua, a linhagem celular necessita "transformar-se", ou seja, sofrer uma alteração genética que a permita escapar da senescência, tornando-se "imortalizada". Quanto à forma de crescimento, as células irão crescer aderidas a determinadas superfícies, sendo denominadas de aderentes, ou, ao contrário, permanecerão livres, em suspensão. Linhagens de gliomas, HEK e HeLa, são classificadas como aderentes porque crescem fixadas a uma superfície rígida, formando monocamada. Linfócitos, por sua vez, são linhagens que crescem em suspensão, permanecendo dispersos no meio de cultura.

\section{ONDE SÃO ENCONTRADAS AS LINHAGENS CELULARES?}

A obtenção da linhagem celular de interesse pode ser feita a partir dos repositórios ou bancos de células, que comercializam, estocam e trocam diferentes tipos celulares. Entre os mais conhecidos estão a American Type Culture Collection (ATCC) (http:// www.atcc.org/) e a European Collection of Cell Culture (ECACC) (http://www.hpacultures.org.uk/collections/ecacc.jsp). Temos também repositórios em nosso País, como o Banco de Células do Rio de Janeiro (BCRJ) (http://www.bcri.hucff.ufri.br/).

\section{APLICAÇÕES BIOTECNOLÓGICAS DA CULTURA DE CÉLULAS}

O cultivo em massa de linhagens de células animais é essencial para a fabricação de vacinas virais e muitos produtos de biotecnologia. São comumente referidos como produtos biológicos obtidos pela tecnologia de DNA recombinante, mediante cultura de células. Incluem-se aqui enzimas, hormônios sintéticos, imunobiológicos (anticorpos monoclonais, interleucinas, linfocinas), conforme será abordado no capítulo 17.

\section{VANTAGENS E DESVANTAGENS DO TRABALHO COM CÉLULAS EM CULTURA}

Culturas de células têm uma série de vantagens inegáveis, mas também tem desvantagens que devem ser levadas em consideração. 


\section{VANTAGENS DA PESQUISA COM CÉLULAS EM CULTURA}

- Permite um controle preciso do ambiente. Em uma cultura é possível controlar muitos fatores ambientais: físico-químicos (temperatura, $\mathrm{pH}$, pressão osmótica, os níveis de $\mathrm{O}_{2}$, $\mathrm{CO}_{2}$ ), da tensão superficial e fisiológicos (hormônios, fatores de crescimento, a densidade celular).

- Caracterização e homogeneidade da amostra. Células de linhagem de células cultivadas são homogêneas, com morfologia e composição uniforme. Pode-se facilmente obter um grande número de réplicas idênticas, o que evita a heterogeneidade das amostras com animais vivos (ex. ratos, camundongos).

- Economia. Culturas de células comumente requerem menor quantidade de reagentes e fármacos.

- A pesquisa biomédica requer a eutanásia de animais utilizados na experimentação científica. A cultura celular nem sempre pode substituir o ensaio in vivo, mas é uma alternativa válida em muitas situações. Permite refinar os estudos ou mesmo reduzir o número de animais utilizados nos ensaios in vivo.

\section{DESVANTAGENS PARA A CULTURA DE CÉLULAS}

- Técnica sensível a contaminações. Sabe-se que as células animais em cultura crescem mais lentamente do que microrganismos que possam estar ali presentes (fungos, leveduras, bactérias, micoplasma). Portanto, cultivos celulares requerem a manutenção de condições de assepsia em todos os momentos.

- Número e custo. Há limitação em termos de quantidade de fármaco produzida, requerendo-se instalações em plantas industriais de alto custo, para quantidades acima de $100 \mathrm{~g}$, por exemplo.

- Instabilidade. Muitas das linhas de células contínuas são instáveis, devido a alterações genéticas na divisão celular. Ou seja, podem-se encontrar diferenças significativas na linhagem celular de uma geração para a seguinte. A única maneira de contornar este problema é utilizar linhagens estáveis que sejam obtidas a partir de um estoque de células congeladas. Este procedimento deve ser realizado rotineiramente, a cada certo número de gerações. 


\section{QUAIS EQUIPAMENTOS BÁSICOS SÃO NECESSÁRIOS PARA O CULTIVO CELULAR?}

Conforme citado anteriormente, a manutenção de um laboratório de cultura de células envolve cuidados rigorosos para manipulação dos cultivos, condições adequadas para crescimento celular e equipamentos auxiliares. Os equipamentos básicos de uma sala de cultivo celular são: 1. Fluxo lâminar; 2. Centrífuga; 3 . Microscópio invertido; 4. Incubadora/estufa de $\mathrm{CO}_{2} ; 5$. Câmara de Neubauer; 6. Contador de células (Fig. 2.1).

O fluxo laminar é um equipamento necessário para manter condição de isolamento em relação ao ambiente do laboratório, obtido pela geração, como o próprio nome diz, de uma lâmina de ar que impede 0 acesso de contaminantes ao ambiente interno onde as culturas são manipuladas (Fig. 2.1-1). A centrífuga é utilizada para obtenção de células via centrifugação, durante o procedimento de passagem celular (Fig. 2.1-2). 0 microscópio invertido é um tipo de microscópio no qual as objetivas situam-se na posição inferior em relação ao material a ser inspecionado, daí o termo "invertido" (Fig. 2.1-3). Permite a visualização das células para análise de sua morfologia, do grau de confluência e de eventuais contaminações com microorganismos. A incubadora ou estufa de $\mathrm{CO}_{2}$ permite a obtenção de condições necessárias para a sobrevivência e multiplicação das células em cultura (2.1-4). A câmara de Neubauer e o contador de células são utilizados para a quantificação do número de células obtido. Esta determinação permite a contagem correta para novas passagens celulares e, principalmente, para manter homogeneidade numérica entre distintos grupos experimentais submetidos a determinados tratamentos (2.1-5 e 2.1-6). 


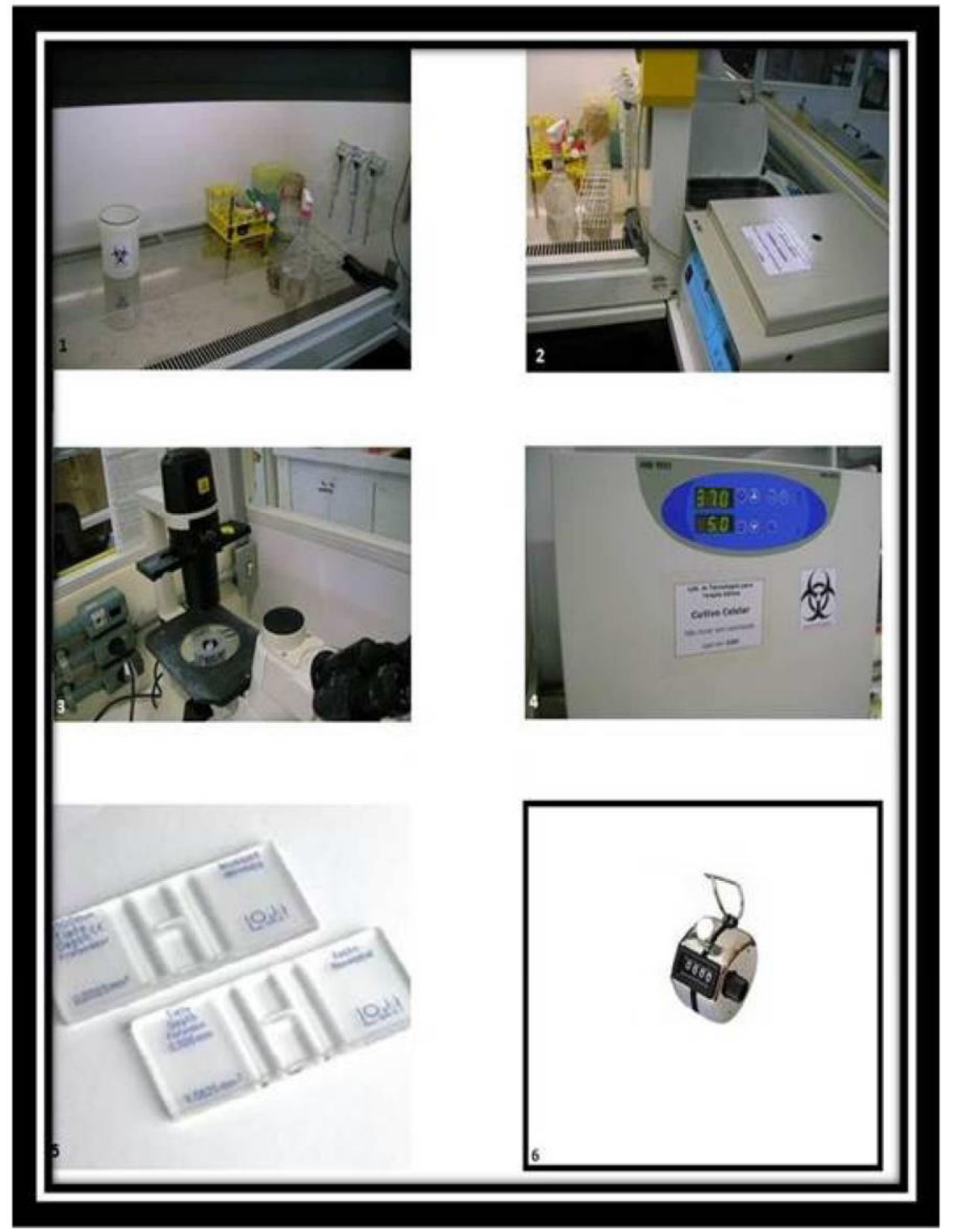

Figura 2.1 - Equipamentos básicos utilizados em uma sala de cultivo celular. 1- Fluxo lâminar. 2- Centrífuga. 3- Microscópio invertido. 4-Incubadora/estufa de $\mathrm{CO}_{2}$. 5- Câmara de Neubauer. 6-Contador de células.

Além dos equipamentos básicos da sala de cultivo, também são utilizados o botijão de nitrogênio e materiais de laboratório (Fig. 2.2). 0 botijão de nitrogênio é requerido para armazenamento de células na temperatura de $-196^{\circ} \mathrm{C}$ (Fig. 2.2-1). A correta medição de volumes é importante nestes procedimentos, o que exige micropipetas e suas ponteiras (Fig 2.2-2, 2.2-8). Também são empregados tubos plásticos graduados, comumente referidos como Falcons, e microtubos Eppendorf de 1,5mL (Fig. 2.2-5, Fig. 2.2-4). Frascos especiais para cultivo (garrafas de cultivo) permitem o crescimento das células e a exposição às condições da estufa de $\mathrm{CO}_{2}$ (Fig. 2.2-6). Finalmente, temos os pequenos tubos utilizados para armazenamento das linhagens celulares, congeladas em botijão de nitrogênio, os denominados criotubos (Fig. 2.2-3). 


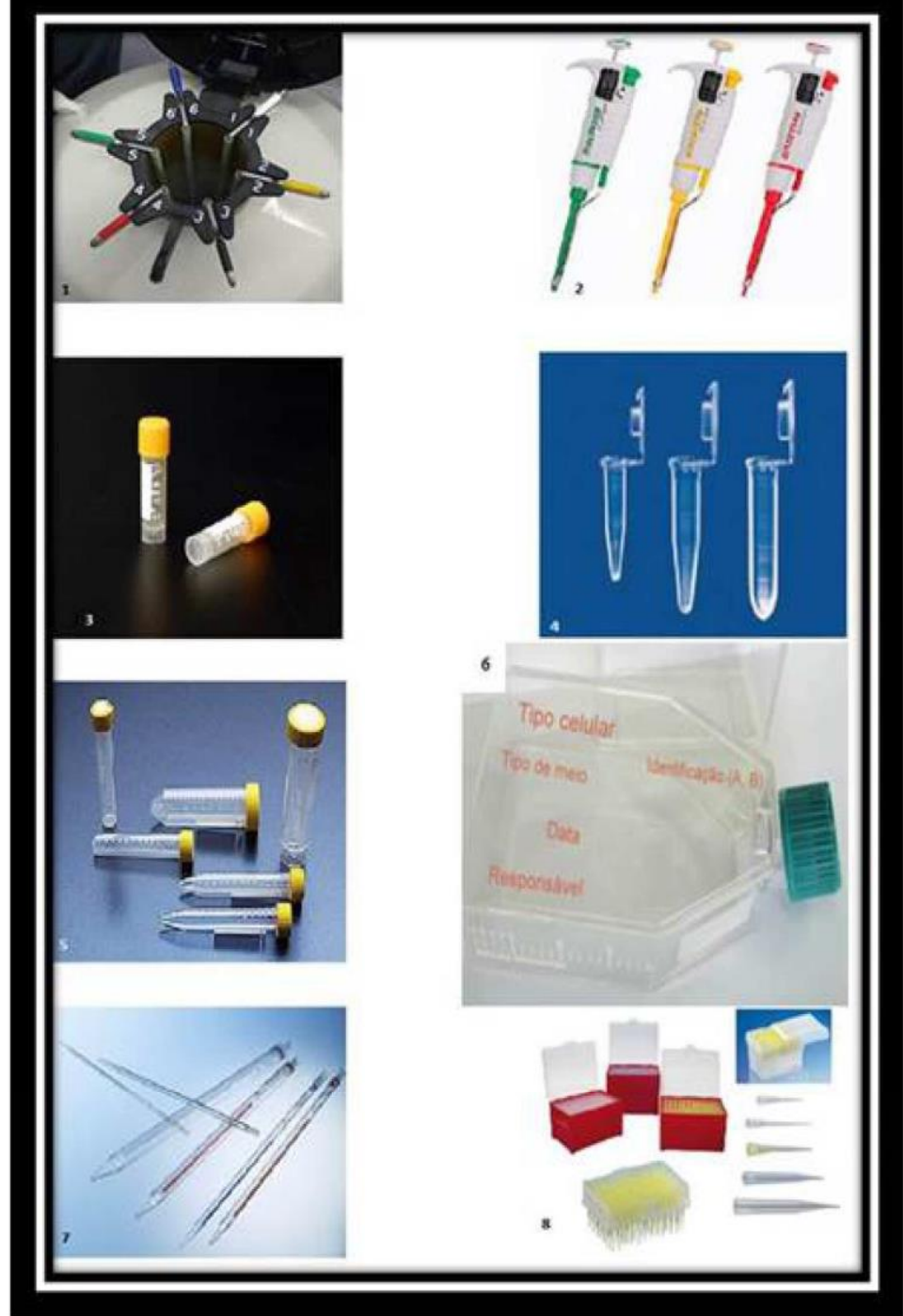

Figura 2.2 - Equipamentos e plásticos utilizados em cultivo celular. 1- Botijão de nitrogênio líquido; 2-Micropipetas automáticas; 3 - Criotubos para congelamento de células; 4- Microtubos tipo Eppendorf; 5- Tubos cônicos tipo Falcon; 6- Garrafa de cultivo celular; 7-Pipetas sorológicas; 8- Ponteiras. As imagens provêm de divulgação comercial.

\section{Quadro 1.2 - Terminologia relativa à cultura de células}

Banco de células

Repositores de linhagens celulares e materiais homólogos.

\section{Clone}

Descendência isolada de uma célula específica.

\section{Confluência}

Taxa de ocupação da área disponível para crescimento, dentro de uma garrafa de cultivo, por exemplo.

\section{Cultura de células}

Manutenção de células dissociadas em cultura. 


\section{Cultura de tecidos}

Manutenção de determinado tecido em cultura.

\section{Cultura primária}

Cultura inicial derivada de material in vivo.

\section{Imortalização}

Habilidade imposta às células que as permite sobreviver em cultura por tempo indeterminado.

\section{Linhagem celular}

Subcultura oriunda de um cultivo primário inicial.

\section{Linhagem celular contínua}

Linhagem imortalizada. Cultura que se estende por tempo indefinido.

\section{Linhagem celular finita}

Linhagem de células com passagens limitadas. Neste caso, as células irão entrar em senescência ao atingirem certo número máximo de divisões.

\section{Passagem}

Subcultura de um grupo de células provenientes de um frasco de cultivo.

\section{Substrato}

Matriz onde as células em cultivo crescem. 


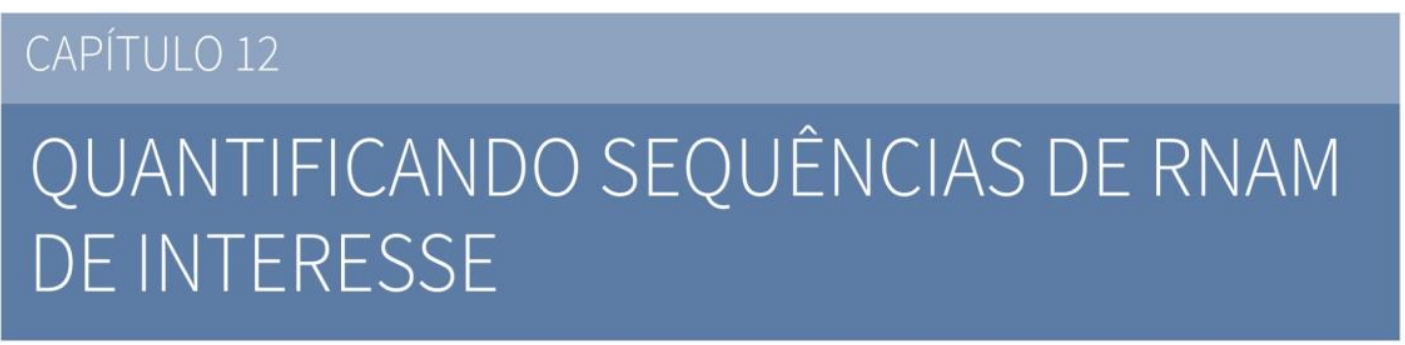

Fernando Francisco Borges Resende e Ricardo Titze-de-Almeida

No capítulo 10, vimos que é possível medir a quantidade de ácidos nucléicos presente em determinada amostra, mediante técnicas de espectrofotometria ou fluorimetria. Juntamente com a eletroforese em gel de agarose (Cap. 8), fornecem informações importantes sobre o rendimento e a qualidade dos ácidos nucléicos extraídos de seu material de origem. Tais métodos não têm capacidade de informar, entretanto, se a expressão de determinado gene está aumentada ou diminuída na condição experimental em teste. $\mathrm{A}$ partir deste momento, nosso eBook irá apresentar algumas técnicas de biologia molecular úteis para a quantificação de moléculas de RNAm de interesse. A quantificação de proteínas será vista na seção seguinte.

No presente capítulo, vamos inicialmente abordar a técnica de PCR convencional, pois fornece as bases metodológicas para a amplificação de sequências de interesse. Depois será abordado o PCR em tempo real, que permite avaliar mudanças no fluxo da expressão gênica, em particular nos níveis de RNAm.

\section{O QUE SIGNIFICA A TÉCNICA DE PCR? QUAL O PRINCÍPIO DO MÉTODO?}

Até meados da década de 80, a única maneira de alcançarmos o isolamento de um gene de interesse requeria o uso de bibliotecas gênicas ou de bibliotecas de expressão. Tais bibliotecas continham os genes de determinado organismo, clonados em plasmídeos, no interior de bactérias. A identificação do gene de interesse nas placas de cultura de $E$. coli era um processo demorado e muito laborioso. Entretanto, uma nova metodologia totalmente in vitro veio a possibilitar a identificação de genes de interesse, de maneira rápida e simples. Nos encontros informais entre colegas de trabalho à época, costumava-se ouvir a frase instigante "Um pesquisador está dizendo que desenvolveu um método no qual é possível isolar qualquer gene do organismo, em poucas horas"! 
A técnica da PCR (do inglês Polymerase Chain Reaction) foi desenvolvida nos anos 80 pelo cientista americano Kary Mullis. De forma geral, o método realiza a síntese dos fragmentos de DNA de interesse, através da ação de uma enzima DNA polimerase. A capacidade destas enzimas de realizar a polimerização de nucleotídeos durante a duplicação do DNA foi vista no capítulo 5, fig. 5.5. Esta mesma habilidade é utilizada na técnica de PCR, onde os nucleotídeos são adicionados um a um nas fitas que se elongam. Também vimos que a importância dos primers ou iniciadores para a duplicação do DNA (Fig. 5.10).

O PCR utiliza os mesmos princípios de replicação, porém a reação ocorre in vitro, em pequenos tubos eppendorf. De forma sintética, a enzima Taq DNA polimerase irá polimerizar novos nucleotídeos a partir de iniciadores (primers) que se anelam nas extremidades da sequência a ser amplificada, gerando-se inúmeras cópias ao final dos ciclos de PCR. Cada ciclo de PCR é composto por três etapas básicas (Fig. 12.1):

- Etapa 1 - Desnaturação. A amostra de DNA em dupla fita é aquecida a $94^{\circ} \mathrm{C}$, havendo quebra das pontes de hidrogênio e assim a separação das duas fitas de DNA. A desnaturação é necessária para que os primers possam reconhecer as sequências a serem amplificadas, e isto só é possível se o DNA estiver como fita simples.

- Etapa 2 - Anelamento. Após a desnaturação da etapa 1, o DNA é rapidamente resfriado. Isto permitirá que os primers se hibridizem com as seqüências complementares, situadas em cada uma das fitas de DNA (anelamento dos primers).

- Etapa 3 - Extensão. A enzima Taq DNA polimerase irá polimerizar os nucleotídeos presentes na reação ( $A, T, C$ ou $G$ ), elongando a fita de DNA a partir dos primers; assim formam-se os chamados "produtos de PCR" ou amplicons.

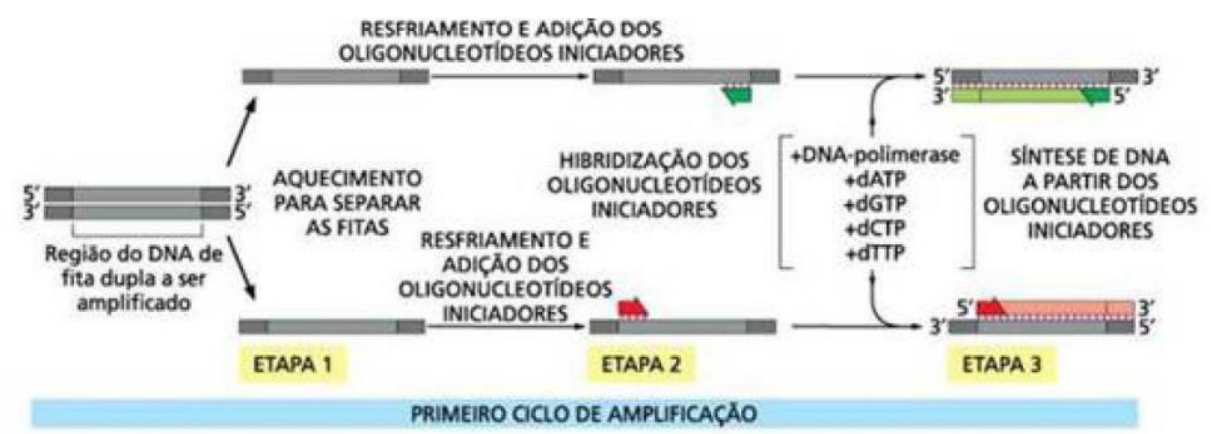

Figura 12.1 - Os primers em uma reação de PCR sinalizam o trecho de DNA que deve ser amplificado. A seqüência a ser amplificada é delimitada pelos iniciadores ou primers (setas verde e vermelha), que irão se anelar via pontes de hidrogênio nas extremidades do DNA original. A partir destes primers, a enzima Taq 
DNA polimerase irá acrescentar novos nucleotídeos, realizando a síntese de DNA em cada ciclo de PCR. Notar as três etapas básicas dos ciclos de PCR: 1 - desnaturação por aquecimento; 2 - anelamento (hibridização dos iniciadores, correspondendo às setas verde e vermelha); 3 - extensão, ou seja, síntese de DNA a partir dos iniciadores. Modificado de Alberts et al. - Fundamentos da Biologia Celular, 3. Ed., Artmed, 2011.

Os ciclos de PCR podem ser repetidos várias vezes (ex. 30 vezes), gerando milhões de cópias do fragmento de DNA de interesse. 0 esquema e a legenda da figura 12.2 facilitarão o entendimento do método de amplificação, ciclo a ciclo.

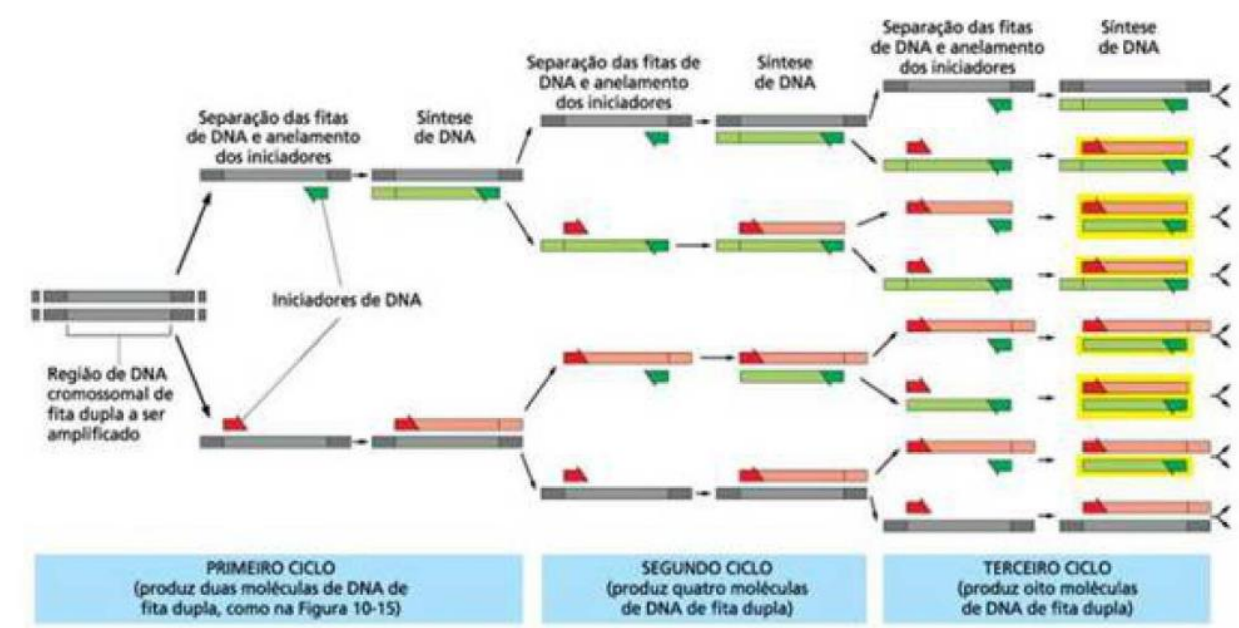

Figura 12.2 - A repetição dos ciclos da PCR permite a formação de milhões de cópias do fragmento de DNA de interesse. Como o ciclo explicado na Figura 12.1 é realizado repetidamente, os fragmentos amplificados no ciclo anterior servem de molde para o novo ciclo recém-iniciado. Cada ciclo então duplicará a quantidade de DNA sintetizado no ciclo anterior. Formam-se, após alguns ciclos, fragmentos de DNA iguais aos das sequências molde iniciais, cuja região é delimitada pelos primers (setas na cor verde e vermelha). No exemplo acima, após três ciclos de PCR, teremos 16 cadeias de DNA. Notar que as cadeias marcadas em amarelo são exatamente do mesmo comprimento e iguais às fitas originais, delimitadas pelos iniciadores. Modificado de Alberts et al. - Fundamentos da Biologia Celular, 3. Ed., Artmed, 2011.

\section{Curiosidade}

Conforme mostra a figura 12.1, o primeiro passo da reação de PCR consiste na quebra das pontes de hidrogênio entre as bases nucleotídicas do DNA, feita por aquecimento (para revisão desta ligação química, figs. 4.7 e 4.8 do Cap. 4). Trata-se da "desnaturação inicial", que é feita comumente a $94^{\circ} \mathrm{C}$. Como a enzima DNA polimerase, de natureza protéica, se mantém estável a esta temperatura?

A descoberta de uma enzima polimerase termoestável foi um dos aspectos centrais da técnica de PCR. Caso contrário, esta enzima precisaria ser reposta 30 vezes, por exemplo, em um único ensaio de PCR. A enzima termoestável foi identificada em uma bactéria termofílica capaz de sobreviver nas altas temperaturas de nascentes ter- 
mais. Assim foi obtida a enzima Taq polimerase, a partir da bactéria Thermus aquaticus isolada em um gêiser do Parque Nacional de Yellowstone, Estados Unidos.

\section{APLICAÇÕES DA TÉCNICA DE PCR}

O desenvolvimento da metodologia de PCR abriu várias perspectivas para análise de genes, diagnóstico de doenças genéticas e de agentes infecciosos. Outras aplicações especialmente úteis são a clonagem de determinado fragmento de DNA amplificado por PCR para fins de sequenciamento ou manipulação por engenharia genética.

Contudo, muitas vezes é necessário quantificar uma molécula específica de DNA ou RNA. Por exemplo, quando se pretende saber se houve mudança na expressão de determinado RNAm de interesse. Neste caso, pode-se realizar o PCR em tempo real (qPCR) ou a técnica de Northern blotting, hoje bem menos utilizada (ver quadro abaixo).

\section{Comentários importantes}

1. Uma técnica anteriormente desenvolvida para estudos de expressão gênica foi o Northern blotting. Neste caso, a amostra de RNA é inicialmente extraída das células ou tecidos e submetida à eletroforese em gel de agarose (técnicas apresentadas nos capítulos 7 e 8). Depois, é feita transferência do gel para a membrana apropriada ( blotting), seguindo-se à hibridização com uma sonda marcada, capaz de identificar o RNAm de interesse. O Northern blotting ainda é utilizado nos dias atuais, por ser um método robusto e sensível; contudo é uma ferramenta mais demorada e laboriosa quando comparada ao PCR em tempo real.

2. Conforme já comentado no capítulo 7, muitas vezes é interessante manter a morfologia do tecido para identificar áreas de expressão do RNA de interesse. Neste caso, a técnica de hibridização in situ é mais indicada do que o Northern blotting ou o qPCR.

\section{QUAL A DIFERENCCA ENTRE O PCR CONVENCIONAL E O PCR EM TEMPO REAL (qPCR)?}

A rigor, a técnica convencional da PCR não é uma metodologia quantitativa, mas sim qualitativa. Neste PCR, o material é analisado ao final do processo de amplificação, em um 
gel de agarose (para revisão sobre eletroforese, veja capítulo 8). A PCR em tempo real (RT-qPCR), por sua vez, é uma técnica quantitativa, utilizada para estimar a concentração de um determinado fragmento de DNA ou de cDNA na amostra. As duas metodologias são comparadas na Fig. 12.3, apresentada abaixo. Diferente da PCR convencional, que determina a presença ou ausência de um determinado trecho de DNA a partir da quantidade final de produto formado, a qPCR nos possibilita saber qual era a quantidade inicial de material. Com isso, é possível determinar o conteúdo do RNAm de interesse nos grupos experimentais e, assim, inferir sobre alterações na expressão do gene em estudo frente a diferentes tratamentos ou fenótipos celulares. Uma vez que método possibilita determinar a quantidade da molécula alvo obtida a cada ciclo de amplificação, recebeu a denominação de PCR em tempo real.

PCR convencional
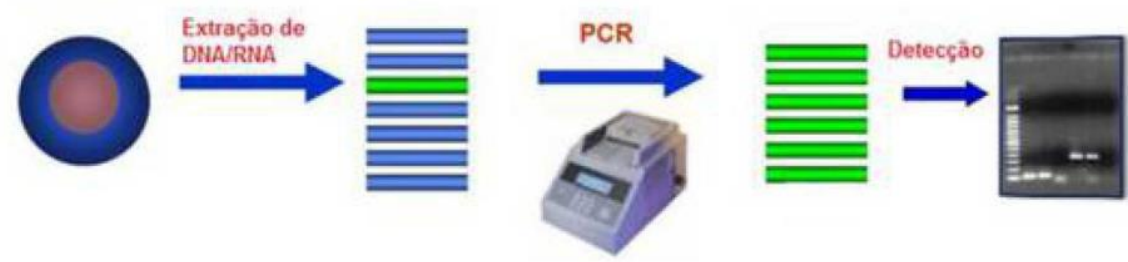

PCR em Tempo Real
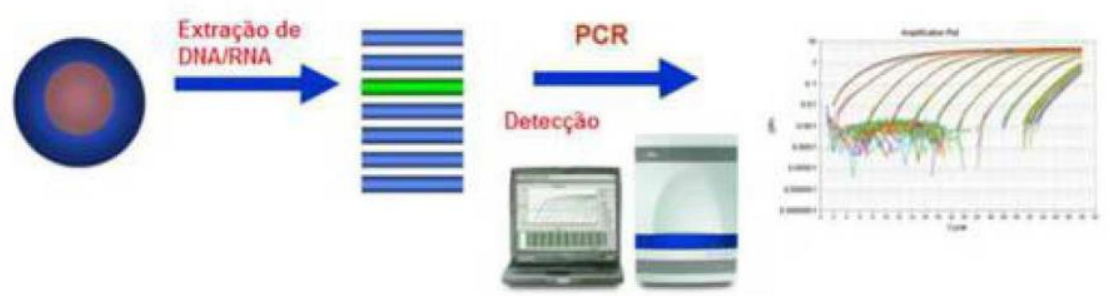

Figura 12.3 - Visão comparativa entre as técnicas de PCR convencional e de PCR em tempo real (qPCR). Nota-se que na técnica convencional, ao final dos ciclos de amplificação, há a formação de inúmeras cópias idênticas ao trecho do DNA original delimitado pelos primers. Concluídos os ciclos da reação, é feita a corrida em gel de agarose (Cap. 8), sendo o produto de PCR visualizado como uma banda luminosa de tamanho conhecido. Já no PCR em tempo real, como a própria denominação refere, o sinal fluorescente emitido é monitorado a cada ciclo de amplificação. Pode-se assim mensurar a quantidade inicial daquele segmento de RNA ou de DNA presente no início da reação. Modificado de Introdução à PCR quantitativa. Life Technologies, 2012.

\section{PRINCÍPIOS DO MÉTODO DE PCR EM TEMPO REAL}

Quando falamos em quantificar a taxa de expressão de um gene, buscamos medir a quantidade de RNAm presente no citoplasma da célula. Para isso, deve ser realizada primeiramente a extração de RNA (Cap. 7) e a transcrição reversa do mesmo RNA. A transcrição 
reversa irá copiar sequências de RNA de forma "reversa", formando-se assim sequências de DNA, daí o termo cDNA (Cap. 11). Isto é necessário, pois a Taq DNA polimerase, que irá amplificar o material, não consegue utilizar moléculas de RNA como molde ou template. Pois bem, após essa etapa, o material é colocado no termociclador (Fig.

12.4), no qual irá ocorrer a amplificação. Os primers irão se ligar aos locais específicos a serem amplificados no DNA, e então ocorrerá a polimerização. Esse processo se desenvolve em ciclos bem parecidos à PCR convencional.

Aqui temos uma diferença importante no PCR em tempo real. Para mensurar a concentração da molécula de RNA (convertido em cDNA), o método de qPCR terá como base a detecção e quantificação de um sinal fluorescente. Ou seja, a cada vez que ocorre um ciclo de amplificação, uma quantidade de luz é emitida e detectada pelo equipamento. Quanto maior a quantidade inicial de RNA, tanto maior será a fluorescência emitida, o que será detectado pelo equipamento.

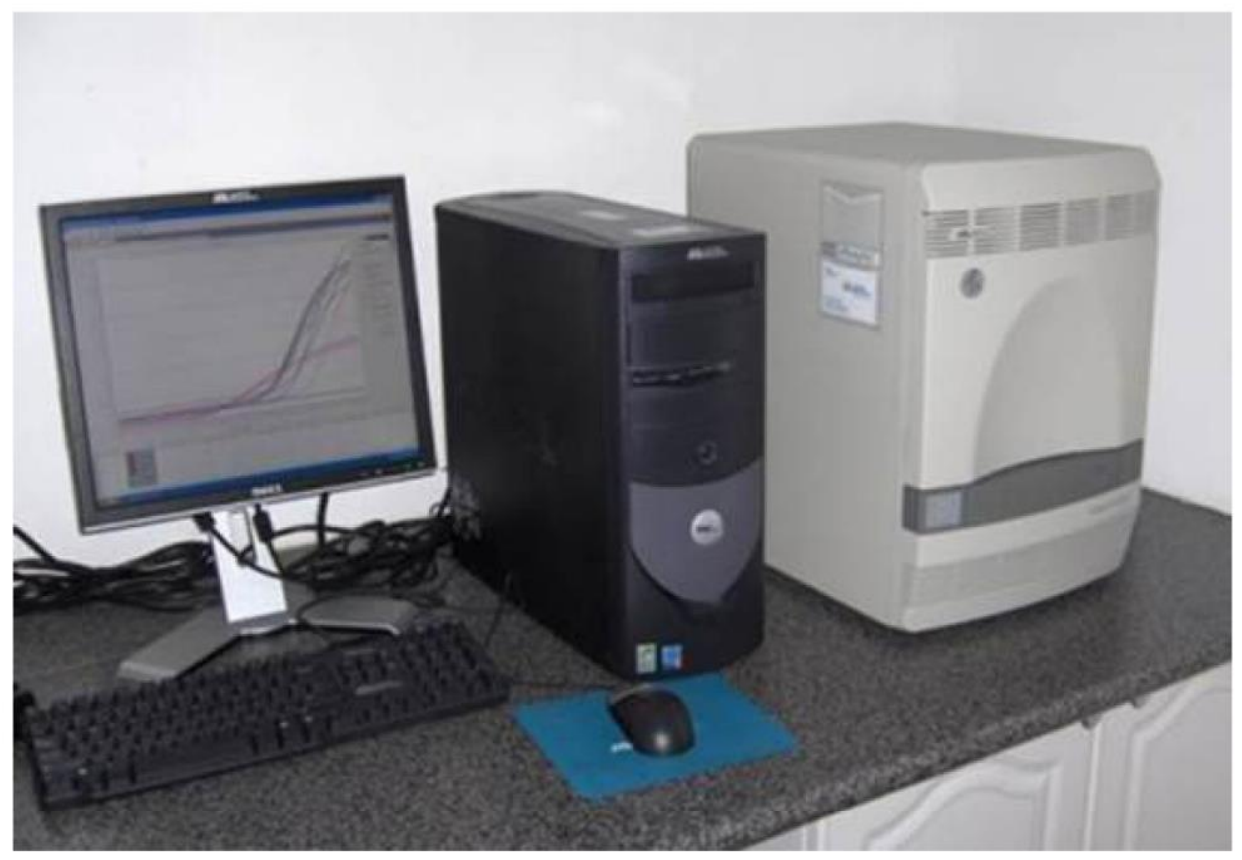

Figura 12.4 - Equipamento para PCR em tempo real. O aparelho é composto basicamente pelos seguintes componentes: 1. bloco termociclador, que tem a função de esquentar e resfriar as amostras; 2. emissor de luz, incumbido de excitar os agentes fluorescentes adicionados à reação; 3. detector de fluorescência para captar o sinal emitido e; 4. computador, com a função de controlar o equipamento de PCR e processar os dados obtidos.

Para emissão de fluorescência, são utilizados comumente dois tipos de agentes: o SYBR Green e o Taq Man (Fig. 12.5). 
- SYBR Green: Trata-se de agente intercalante excitável, que se liga à cadeia dupla de DNA. À medida que ocorre a amplificação, o agente irá se intercalar progressivamente às novas moléculas de DNA. Ao ser excitado, emitirá a sua fluorescência. Assim, a quantidade de fluorescência emitida é proporcional à quantidade de DNA de fita dupla existente inicialmente; havendo mais moléculas de DNA, tanto maior será a fluorescência emitida.

- TaqMan: Consiste em oligonucleotídeos (sondas) com modificações nas duas extremidades: um fluoróforo reporter (que emite a radiação) em uma das extremidades (em 5') e um quencher na extremidade 3', que absorve a luz que o repórter emite, impedindo assim a sua detecção. A sonda (probe) estará posicionada no intervalo entre os dois primers, sense e antisense. No decorrer do PCR, a DNA polimerase irá encontrar a sonda no caminho do segmento que está sendo amplificado e irá degradá-la. Com isto, o quencher ficará distanciado do repórter, deixando de absorver a sua fluorescência. 0 resultado será a emissão de fluorescência, que aumentará a cada ciclo de amplificação.

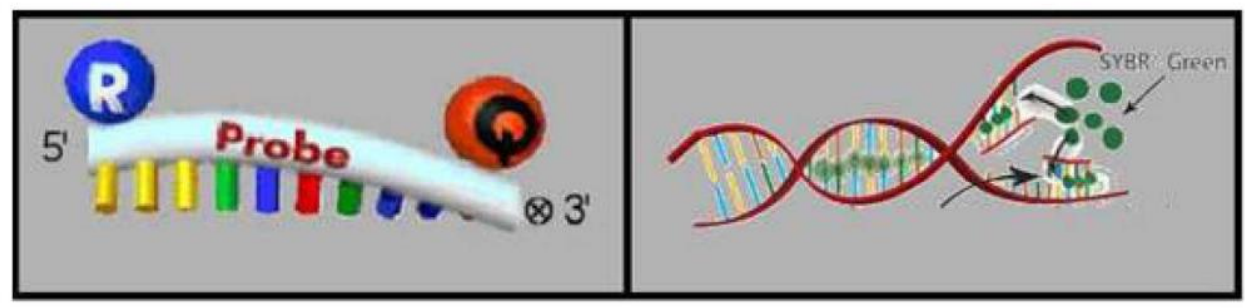

Figura 12.5 - Esquema comparativo das químicas mais utilizadas para PCR em tempo real. À esquerda, uma sonda TaqMan ${ }^{\circledR}$ composta de sequência de DNA sintético especifica a um trecho de DNA (barra branca, probe). A sonda contém em uma das extremidades um agente emissor de fluorescência, chamado de Reporter (círculo azul, R), e na outra um agente inibidor de fluorescência denominado de Quencher (círculo vermelho, Q). À direita, o agente intercalante SYBR GREEN ${ }^{\text {( }}$ que se liga eficientemente ao DNA em dupla fita, emitindo luminosidade verde na faixa de $520 \mathrm{~nm}$.

\section{A CORRETA ESCOLHA DOS PRIMERS É PASSO FUNDAMENTAL NO ENSAIO DE qPCR}

Ao se planejar um ensaio para análise da expressão gênica, ou qualquer outro que utilize a metodologia da PCR em tempo real, é importante destacar a etapa do desenho dos primers. Como vimos anteriormente, são esses oligonucleotídeos iniciadores que irão delimitar o segmento a ser amplificado pela Taq DNA polimerase. Na técnica de PCR em tempo real, há vários fatores que devem ser considerados. Inclui-se aqui o conteúdo de $\mathrm{G}$ e C, fator determinante na definição da melting temperature (Tm) que 
deve ficar entre 60 e $64^{\circ} \mathrm{C}$, a formação de hairpins, self-dimers e hetero-dimers, entre outros. De maneira objetiva, os primers devem ser selecionados com base nas seguintes características:

1- O tamanho desejado do produto de PCR (amplicon) é de 100 pares de bases;

2- Percentuais de guanina e citosina de aproximadamente $50 \%$;

3- Reduzida complementariedade intramolecular, evitando-se hairpins e self-dimers;

4- Reduzida complementariedade intermolecular, evitando-se hetero-dimers;

5- Reduzida variação nas temperaturas de anelamento $\Delta(\mathrm{Tm})$ entre os primers forward e reverse, preferencialmente próxima de $1^{\circ} \mathrm{C}$.

Há vários softwares disponíveis para o desenho e análise de primers específicos para qPCR, como o software OligoAnalyser 3.1 disponibilizado pela IDT (Integrated DNA Technologies) (http://www.idtdna.com) e o Primer Express da Life Technologies (http:// www.lifetechnologies.com). Esses programas classificam os primers de acordo com sua eficiência, que corresponde à adequação às características desejáveis citadas acima.

\section{O QUE SÃO OS GENES CONTROLES ENDÓGENOS OU HOUSE- KEEPING GENES? QUAL A SUA IMPORTÂNCIA NO qPCR?}

Além dos grupos controle, incluídos nos experimentos para fins de comparação com o grupo tratado, também se faz necessário incluir no ensaio de expressão gênica, realizado por PCR em tempo real, os chamados genes controles endógenos. Também denominados de housekeeping genes, são caracterizados por sua estabilidade, ou seja, por não apresentarem mudança de expressão gênica diante das condições experimentais em estudo. Comumente espera-se que o gene controle endógeno não apresente variações em resposta a determinado tratamento. Na situação ideal, o tratamento das células ou dos animais afetaria o RNAm que se quer estudar, sem entretanto produzir efeitos no gene controle endógeno. $O$ grupo de pesquisa deve buscar aquele controle endógeno que melhor se adeque ao experimento em curso. Exemplos de housekeeping genes são: poly(A) 
polymerase alpha (PAPOLA), gliceraldeído-3-fosfato desidrogenase (GAPDH), betaactina (ACTB), proteína de ligação ao TATA box (TBP), e transferrina humana (hTfR).

Nos dois próximos tópicos, iremos abordar aspectos centrais da metodologia de PCR em tempo real: o Ct e a quantificação relativa. Por serem conteúdos com certo grau de complexidade, irão exigir disposição e paciência!

\section{O QUE SIGNIFICA A SIGLA "Ct" - CROSSING THRESHOLD?}

Sabe-se que durante os ciclos iniciais da PCR, ocorre uma alteração muito pequena no sinal de fluorescência, e a leitura é basicamente de pequenos ruídos. Essa alteração é o que define o baseline em um gráfico de amplificação (região da linha de base, $\underline{\text { Fig. }}$ 12.6). Posteriormente, a amplificação entra na fase exponencial, na qual a quantidade do material amplificado irá dobrar a cada ciclo. Um aumento de emissão de fluorescência acima do baseline aponta, dessa forma, a detecção de amplicons acumulados nos ciclos de amplificação. 0 threshold de fluorescência deve ser ajustado acima do baseline, e o Ct (crossing threshold) é apontado como o ciclo no qual a fluorescência que está sendo emitida consegue ultrapassar o threshold, havendo duplicação exponencial a cada novo ciclo de PCR (Fig. 12.6). Por fim, há a fase de platô, na qual não se observa mais aumento no número de produtos.

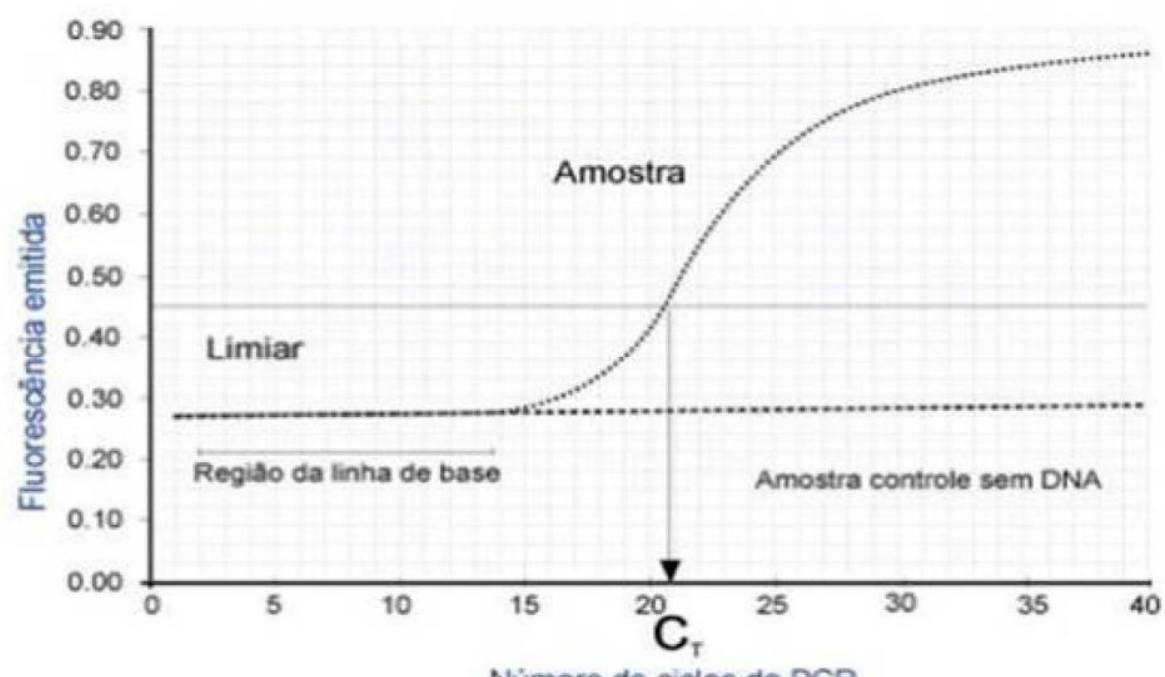

Figura 12.6 - Deteç̧ão da fluorescência no PCR em tempo real. O gráfico indica o número de ciclos de amplificação e o momento de deteç̧ão do Ct, próximo do $20^{\circ}$ ciclo de amplificação. 


\section{O QUE SIGNIFICA QUANTIFICAÇÃO RELATIVA?}

A quantificação relativa é um método utilizado para analisar as alterações na expressão gênica de uma determinada amostra em teste, em relação à amostra controle (amostra de referência). Por exemplo, para se determinar a expressão de um gene em resposta a um medicamento, deve-se usar a quantificação relativa (Fig. 12.7). Mede-se assim o nível de expressão do gene específico, na amostra tratada com o medicamento, e isso é então comparado com o nível de expressão desse mesmo gene em uma amostra que não tenha recebido o tratamento, o chamado grupo controle.

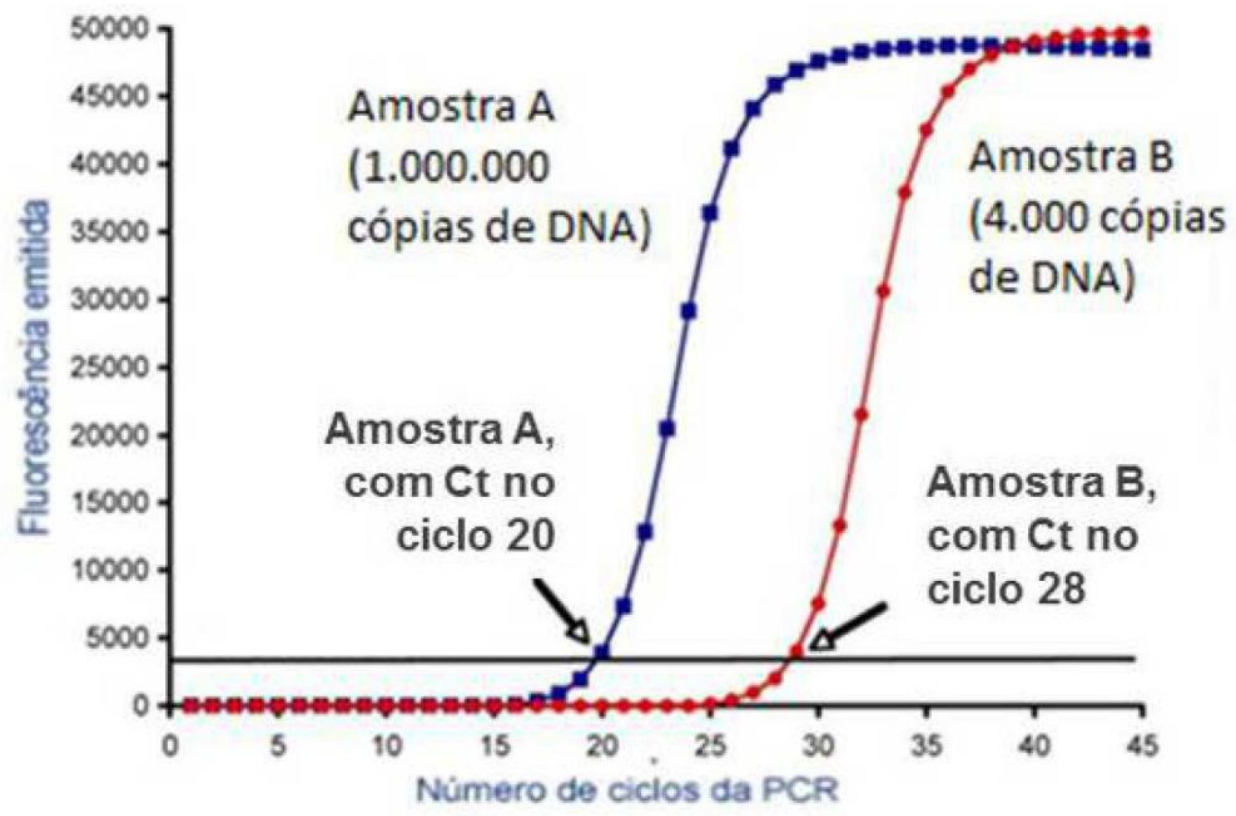

Figura 12.7 - Comparação de duas amostras, $A$ e B, quanto aos valores de Ct. Observar que a amostra $A$ possui número superior de cópias de DNA em relação à amostra B (1.000.000 em comparação com 4.000). Esta diferença resulta em valor de Ct menor para a amostra $\mathrm{A}(\mathrm{Ct}=20)$ quando comparada com a amostra $B(C t=28)$. Notar que o valor de Ct é inversamente proporcional ao do número de moléculas da amostra.

É importante destacar que o valor de Ct é inversamente proporcional ao número de moléculas de RNAm presentes na amostra (Fig. 12.7). Ou seja, quanto menor o valor de Ct, maior será a quantidade de RNAm no grupo em estudo. Uma metodologia comumente utilizada para expressar efeitos de silenciamento gênico por interferência de RNA foi denominada de método de $2^{-\Delta \Delta C t}$. Este cálculo informa o número de vezes que o conteúdo de RNAm foi diminuído no grupo tratado em relação ao grupo controle.

Quadro 12.1 - Terminologia aplicada ao PCR em tempo real. 


\section{Alvo}

Uma sequência de RNA ou DNA ou um gene de interesse que se deseje amplificar por PCR.

\section{Amplicon}

Produto de PCR. Gerado a partir da amplificação de determinada região do DNA, delimitada pelos primers sense $e$ antisense.

\section{Baseline}

O sinal fluorescente de fundo (background) emitido durante os primeiros ciclos da PCR, antes do instrumento de PCR em tempo real detectar a amplificação do produto da PCR.

\section{Controle endógeno}

Gene controle endógeno ou housekeeping gene, cuja expressão não deve se alterar diante das condições experimentais em teste. Esta sequência deve ser amplificada no mesmo ensaio em que são testados os genes alvo de interesse do pesquisador.

\section{Ct - "Crossing threshold"}

O Ct é o número do ciclo no qual a fluorescência gerada dentro de uma reação cruza a linha threshold, indicando o ponto a partir do qual a curva de amplificação passa a ter crescimento logarítmico. É o principal dado fornecido pelo PCR em tempo real, pois permite comparar a expressão dos genes de interesse ou a quantidade de determinado DNA na amostra.

\section{Primers ou iniciadores}

São pares de oligonucleotídeos específicos para a sequência que se deseje amplificar. Cada um dos primers irá reconhecer e se ligar a uma das extremidades do fragmento de interesse, sendo comumente referidos como primers sense e antisense ou, também, primers forward e reverse. A partir das posições de anelamento dos primers sense e antisense, a enzima taq polimerase irá amplificar a região de interesse.

\section{Bibliografia recomendada}

Alberts B et al. Fundamentos da Biologia Celular, 3․ Ed. ArtMed Editora S.A., 2011.

Bustin, S.A. et al. Absolute quantification of mRNA using real-time reverse transcription polymerase chain reaction assays. Journal of Molecular Endocrinology 25:169-193, 2000.

Bustin, S.A. et al. The MIQE Guidelines: Minimum Information for Publication of Quantitative Real-Time PCR Experiments. Clinical Chemistry, 611-622, 2009.

Life Technologies. Apostila de Introdução à PCR quantitativa. São Paulo. 2012.

Livak KJ, Schmittgen TD. Analysis of relative gene expression data using real-time quantitative PCR and the 2(-Delta Delta C(T)) Method. Methods 25(4):402-8, 2001. 
Mullis, K B. Target amplification for DNA analysis by the polymerase chain reaction. AnnBioClin 48(8): 579-82. 1990.

VanGuilder et al. Twenty-five years of quantitative PCR for gene expression analysis. Biotechniques 44:619-626, 2008.

Watson, J.D. et al. DNA recombinante - Genes e Genomas, $3^{\circ}$ Ed. ArtMed Editora S.A., 2009.

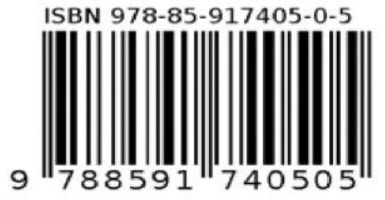

